1839

\title{
Winter Studies and Summer Rambles in Canada
}

Anna Jameson

How does access to this work benefit you? Let us know!

Follow this and additional works at: https://commons.und.edu/settler-literature

\section{Recommended Citation}

Jameson, Anna, "Winter Studies and Summer Rambles in Canada" (1839). Settler Literature Archive. 137. https://commons.und.edu/settler-literature/137

This Book is brought to you for free and open access by the Department of English at UND Scholarly Commons. It has been accepted for inclusion in Settler Literature Archive by an authorized administrator of UND Scholarly Commons. For more information, please contact und.commons@library.und.edu. 
- WINTER STUDIES

$\triangle N D$

\section{S U M M E R R A B L E S}

- IN CANADA.

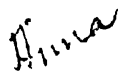

BY MRS. JAMESON,

\section{Auraor or}

"Characteristics of Women," "female sovereigns," \&e., \&e.

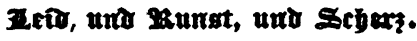
RAREL.

IN TWO VOLUMES:

VOL. I.

N E.W - Y O R K :

- WIley AND PUTNAM, 161 BROADWAY.

1839.

Cheeked

May 1013 


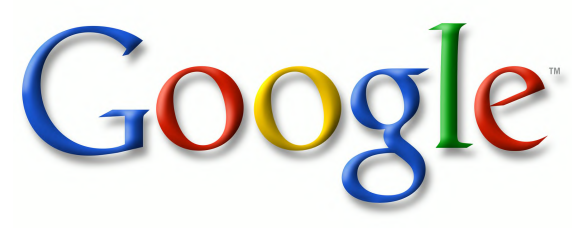

This is a digital copy of a book that was preserved for generations on library shelves before it was carefully scanned by Google as part of a project to make the world's books discoverable online.

It has survived long enough for the copyright to expire and the book to enter the public domain. A public domain book is one that was never subject to copyright or whose legal copyright term has expired. Whether a book is in the public domain may vary country to country. Public domain books are our gateways to the past, representing a wealth of history, culture and knowledge that's often difficult to discover.

Marks, notations and other marginalia present in the original volume will appear in this file - a reminder of this book's long journey from the publisher to a library and finally to you.

\section{Usage guidelines}

Google is proud to partner with libraries to digitize public domain materials and make them widely accessible. Public domain books belong to the public and we are merely their custodians. Nevertheless, this work is expensive, so in order to keep providing this resource, we have taken steps to prevent abuse by commercial parties, including placing technical restrictions on automated querying.

We also ask that you:

+ Make non-commercial use of the files We designed Google Book Search for use by individuals, and we request that you use these files for personal, non-commercial purposes.

+ Refrain from automated querying Do not send automated queries of any sort to Google's system: If you are conducting research on machine translation, optical character recognition or other areas where access to a large amount of text is helpful, please contact us. We encourage the use of public domain materials for these purposes and may be able to help.

+ Maintain attribution The Google "watermark" you see on each file is essential for informing people about this project and helping them find additional materials through Google Book Search. Please do not remove it.

+ Keep it legal Whatever your use, remember that you are responsible for ensuring that what you are doing is legal. Do not assume that just because we believe a book is in the public domain for users in the United States, that the work is also in the public domain for users in other countries. Whether a book is still in copyright varies from country to country, and we can't offer guidance on whether any specific use of any specific book is allowed. Please do not assume that a book's appearance in Google Book Search means it can be used in any manner anywhere in the world. Copyright infringement liability can be quite severe.

\section{About Google Book Search}

Google's mission is to organize the world's information and to make it universally accessible and useful. Google Book Search helps readers discover the world's books while helping authors and publishers reach new audiences. You can search through the full text of this book on the web athttp://books.google.com 


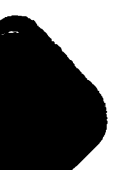



Digitized by GoOgle 
Digitized by GoOgle

$+2$ 
Digitized by Gogle 
$\because \div$

Printed by William Osborn, 88 William-street. 


\section{P R E F A C E.}

IN venturing to place before the public these "fragments" of a journal addressed to a friend, $I$ cannot but feel considerable misgiving as to the reception such a work is likely to moet with, particularly at this time, when the country to which it partly refers is the subject of so much difference of opinion, and so much animosity of feeling. This little book, the mere result of much thoughtful idleness and many an idle thought, has grown up in. sensibly out of an accidental promise. It never was intended to go before the world in its present crude and desultory form; and I am too sensible of its many deficiencies, not to feel that some explanation is due to that public, which has hitherto regarded my attempts in literature with so much forbearance and kindness.

While in Canada I was thrown into scenes and regions hitherto undescribed by any traveller, (for the northern shores of Lake Huron are almost new ground,) and into relations with the Indian tribes, 
such as few European women of refined and civi lized habits have ever risked, and none have recorded. My intention was to have given the result of what I had seen, and the reflections and comparisons excited by so much novel experience, in quite a different form-and one less obtrusive; but owing to the intervention of various circumstances, and occupation of graver import, I found myself reduced to the alternative of either publishing the book as it now stands, or of suppressing it altogether. Neither the time nor the attention necessary to remodel the whole were within my own power. In preparing these notes for the press, much has been omitted of a personal nature, but far too much of such irrelevant matter still remains; far too much which may expose me to misapprehension, if not even to severe criticism; but now, as heretofore, I throw myself upon " the merciful construction of good women," wishing it to be understood that this little book, such as it is, is more particularly addressed to my own sex. I would fain have extracted, altogether, the impertinent leaven of egotism which necessarily mixed itself up with the journal form of writing ; but in making the attempt, the whole work lost its original character-lost its air of reality, lost even its essential truth, and whatever it might possess of the grace of ease and pic- 
torical animation : it became fiat, heary, didactic It was found that to extract the tone of personal feeling, on which the whole serios of action and observation depended, was like drawing the thread out of a string of beads-the chain of linked idess and experiences fell to pieces, and became a mere unconnected, incongruous heap. I have been obliged to leave the flimsy thread of sentiment to sustain the facts and observations loosely strung together; feeling strongly to what it may expose me, but having deliberately chosen the alternative, prepared, of course, to endure what I may appear to have defied ; though, in truth, defiance and assurance are both far from me.

These notes were written in Upper Canada, but it will be seen that they have little reference to the politics or statistics of that unhappy and mismanaged, but most magnificent country. Subsequently -I made a short tour through Lower Canada, just before the breaking out of the late revolts. Sir John Colborne, whose mind appeared to me cast in the antique mould of chivalrous honor, and whom I never heard mentioned in either province but with respect and veneration, was then occupied in preparing against the exigency which he afterwards met so effectively. I saw of course something of the state of feeling on both sides, but not enough 
to venture a word on the subject. Upper Canada appeared to me loyal in spirit, but resentful and repining under the sense of injury, and suffering from the total absence of all sympathy on the part of the English government with the condition, the wants, the feelings, the capabilities of the people and country. I do not mean to say that this want of sympatby now exists to the same extent as formerly ; it has been abruptly and painfully awakened, but it has too long existed. In climate, in soil, in natural productions of every kind, the upper province appeared to me superior to the lower province, and well calculated to become the inexhaustible timber-yard and granary of the mother country. The want of a sea-port, the want of security of pro- perty, the general mismanagement of the government lands-these seemed to me the most prominent causes of the physical depression of this sylendid country, while the poverty and deficient education of the people, and a plentiful lack ,of public spirit in those who were not of the people, seemed sufficiently ta account for the moral depression every where visible. Add a system of mistakes and mal-administration not chargeable to any one individual, or any one measure, but to the whole tendency of our colonial government; the perpetual change of officials and change of measures; the 
fluctuation of principles destroying all pablic confidence, and a degree of ignorance relative to the country itself, not credible except to those who may have visited it; add these three things together, the want of knowledge, the want of judgment, the wat of sympathy, on the part of the gorernment, how can we be surprised at the strangely anomalow condition of the goremed ! - that of a land abeolutely teeming with the richest capabilities, yet poor in population, in wealth, and in energy ! But I feel I am getting beyond my depth. Let us hope that the reign of our young Queen will not begin, like that of Maria Theresa, with the loss of one of ber fairest provinces; and that bereafier she may look upon the map of her dominions without the indignant blushes and tears with which Maria Theresen, to the last moment of her bife, contemplated the map of her dismembered empire and regretted her lost Silesia.

I have abstained generally from politics and personalities; from the former, because such discussions are foreign to my turn of mind and above my capacity, and from the latter on principle; and I wish it to be distinctly understood, that whenever I have introduced any personal details, it has been with the express sanction of those most interested; I allnde particularly to the account of Colonel Tal 
bot and the family at the Sault Ste. Marie. For the rest, I have only to add, that on no subject do I wish to dictate an opinion, or assume to speak as one having authority; my utmost ambition extends no farther than to suggest matter for inquiry and reflection. If this little book cuntain mistakes, they will be chastised and corrected, and I shall be glad of it : if it contain but one truth, and that no bigger than a grain of mustard-seed, it will not have been cast into the world in vain, nor will any severity of criticism make me, in such a case, repent of having published it, even in its present undigested, and, I am afraid, unsatisfactory form. 


\section{CONTENTS}

\section{OF THE FIRST VOLCYE.}

\section{WIYTER STEDIES.}

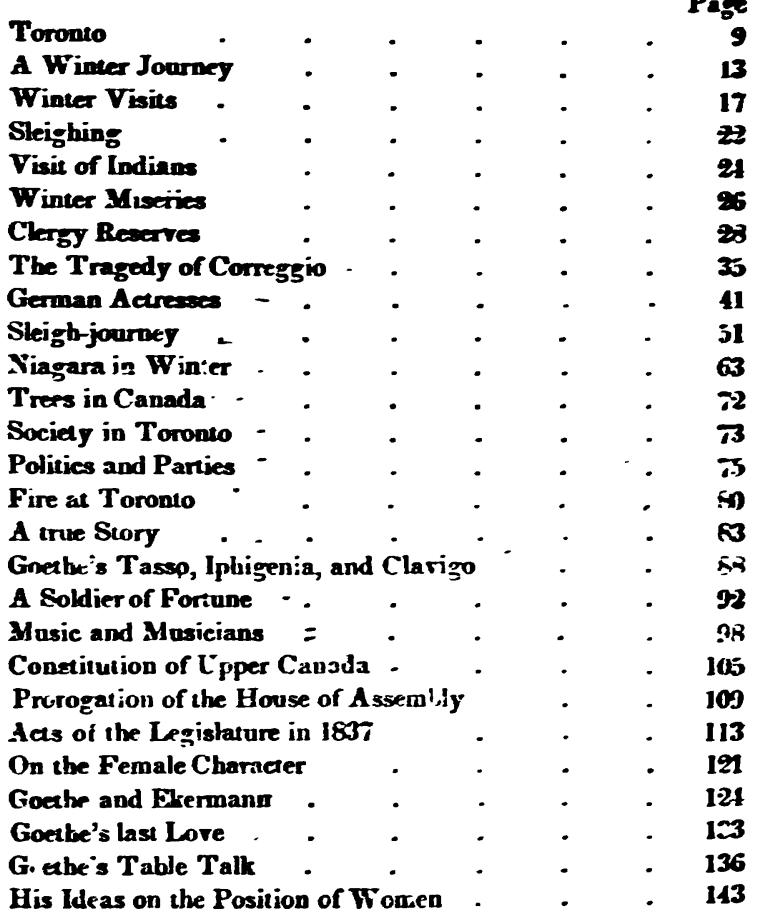




\section{CONTENTE.}

Criminal Calendar of Toronto $\quad . \quad$. $\quad . \quad 179$

Grillparzer's Sappho and Medea $\quad$. $\quad$. $\quad$. 199

Lake Ontario . . . . . . . . 203

Return of Spring . $\quad . \quad$. $\quad$ - $\quad$. $\quad$. 203

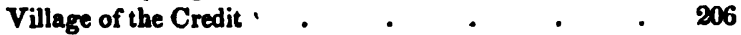

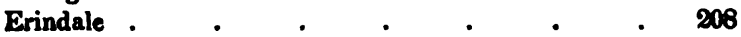

SUMMER RAMBLES.

The Return of Summer . $\quad$ - $\quad$. $\quad$. $\quad$. 219

Sternberg's Novels $\quad$. $\quad . \quad$. $\quad . \quad$. 224

Detached Thoughts. $\quad . \quad$. $\quad$. $\quad$. $\quad$. 235

Mrs. MacMurray $\quad$. $\quad$. $\quad . \quad . \quad . \quad 240$

Niagara in Summer $\quad . \quad$. $\quad . \quad$. $\quad$. 243

$\begin{array}{lllllllll}\text { Story of a Slave . } & . & . & . & . & . & 247\end{array}$

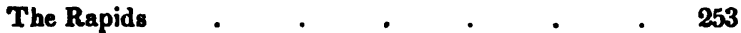

Schiller's Don Carlos . $\quad$. $\quad$. $\quad$. $\quad$. 256

A Dream $\quad$. $\quad$. $\quad$. $\quad$ • $\quad$ • $\quad$. 265

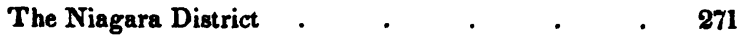

Buffalo $\quad$. $\quad$. $\quad$. $\quad$. $\quad$. $\quad$. 272

Canadian Stage Coaches $\quad$. $\quad . \quad$. $\quad . \quad 277$

The Emigrant . . $\quad . \quad$. $\quad . \quad$. $\quad$. 278

Town of Hamilton . $\quad . \quad$. $\quad . \quad$. $\quad$. 284

Town of Brandtford $\quad . \quad$. $\quad . \quad$. $\quad$. 287

Forest Scenery . $\quad . \quad$. $\quad . \quad$. $\quad$. 295

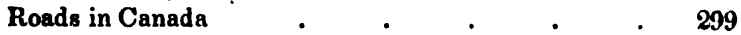

Blandford.-A Settler's Family $\quad$. $\quad$. $\quad$. 300

A Forest Château ' . $\quad$. $\quad$. $\quad$. $\quad$. 302

The Pine Wcods $\quad . \quad$. $\quad . \quad$. $\quad$. 310

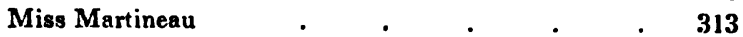

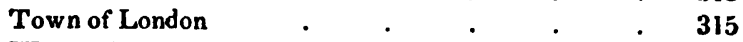

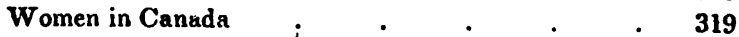

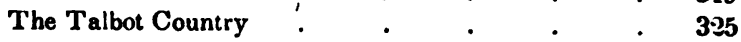

Story of an Emigrant Boy $\quad . \quad$. . . . $\quad .387$

Some account of Colonel Talbot $\quad$. $\quad . \quad$. $\quad 335$ 


\section{W I N T R S TUDIES}

\section{IN CANADA.}

Sind denn die Bänme anch so trostos, 20 verzweifungs rol in ihrem Winter, wie das Herz in seiner Verlassenheit ?

Bettine E. Arnim.

Dec. 20ih.

Toronto-such is now the sonorous name of this our sublime capital-was, thirty years ago, a wilderness, the haunt of the bear and deer, with a little, ugly, inefficient fort, which, however, could not be more ugly or inefficient than the present one. Ten years ago Toronto was a village, with one brick house and four or five hundred inhabitants; five years ago it became a city, containing about five thousand inbabitants, and then bore the name of Little York; now it is Toronto, with an increasing trade, and a population of ten thousand people. So far I write as per book.

What Toronto may be in summer, I cannot tell; they say it is a pretty place. At present its appearance to me, a stranger, is most strangely mean and melancholy. A little ill-built town on low land, at the bottom of a frozen bay, with one very ugly church, witbout tower or steeple; some government offices, built of staring red brick, in the most tasteless, vulgar style imaginable; three feet of snow 
all around; and the gray, sullen, wintry lake, and the dark gloom of the pine forest bounding the prospect; such seems Toronto to me now. I did not expect much; but for this I was not prepared. Perhaps no preparation could have prepared me, or softened my present feelings. I will not be unjust if I can help it, nor querulous. If I look into my own heart, $I$ find that it is regret for what $I$ have left and lost-the absent, not the present-which throws over all around me a chill, colder than that of the wintry day - a gloon, deepen than that of the wintry night.

This is all very dismal, very weak, perhaps; but I know no better way of coming at the truth, than by observing and recording faithfully the impressions made by objects and characters on my own mindor, rather, the impress they receive from my own mind-shadowed by the clouds which pass over its horizon, taking each tincture of its varying mooduntil they emerge into light, to be corrected, or at least modified, by observation and comparison. Neither do I know any better way than this of conveying to the mind of another, the truth, and nothing but the truth, if not the whole truth. So 1 shall write on. Hitherto I have not been accused of looking on the things of this world through a glass darkly, but rather of a contrary tendency. What have I done with my spectacles couleur de rose? - the cheerful faith which sustained me through far worse than any thing I can anticipate here;- the desire to know, the impatience to learn, the quick social sympathies, the readiness to please and 
to be pleased-derived, perhaps, from my Irish blood, and to which I have owed so much of comfort when I have most needed it, so much of enjoyment when least I could have hoped for it-what! and are all forgetten, all gone? Yet am I not quite an icicle, nor an oyster-I almost wish I were! No, worst of all, is this regretful remembrance of friends who loved me, this heart-sick longing after home, and country, and all familiar things and dear domestic faces! I am like an uprooted tree, dying at the core, yet with a strange unreasonable power at times of mocking at my own most miserable weakness. Going to bed in tears last night, after saying my prayers for those far away across that terrible Atlantic, an odd remembrance flashed across me of that Madame de Boufflers, who declared " avec tant de sérieux et de sentiment," that she would consent to go as ambassadress to England, only on the condition of taking with her "vingt-cinq ou vingtsix de ses amis intimes," and sixty or eighty persons who were absolument necessaires d son bonheur. The image of graceful impertinence thus conjured up, made me smile-but am I so unlike her in this fit of unreason? Every where there is occupation for the rational and healthy intellect, every where good to be done, duties to be performed-every where the mind is, or should be, its own world, its own country, its own home at least. How many fine things I could say or quote, in prose or in rhyme, on this subject! But in vain I conjure up Philosophy, "she will not come when I do call for her ;" but in her stead come throngiug sad and sorrowful recol- 
lections, and shivering sensations, all telling mo that I am a stranger among strangers, miserable inwardly and outwardly - and that the thermometer is twelve degrees below zero!

There is much, too, in first impressions, and as yet I have not recovered from the pain and annoyance of my outset here. My friends at New-York expended much eloquence-eloquence wasted in vain !-in endeavouring to dissuade me from a winter journey to Canada. I listened, and was grateful for their solicitude, but must own I did not credit the picture they drew of the difficulties and desagremens I was destined to meet by the way. I had chosen, they said, (Heaven knows I did not choose it,) the very worst seasen for a journey through the state of New-York; the usual facilities for travelling were now suspended; a few weeks sooner the rivers and canals had been open; a few weeks later the roads, smoothed up with snow, had been in sleighing order; now, the navigation was frozen, and the roads so broken up as to be nearly impassable. Then there was only a night boat on the Hudson, " to proceed," as the printed paper set forth, " to Albany, or as far as the ice permitted." All this, and more, were represented to me-and with so much apparent reason and real feeling, and in words and tones so difficult to resist! But though I could appreciate the kindness of those persuasive words, they brought no definite idea to my mind; I could form no notion of difficulties which by fair words, presence of mind, and money in my pocket, could not be obviated. I had travelled half over 
the continent of Europe, often alone, and had never yet been in circumstances where these availed not. In myignorance I could conceive none; but I would not lightly counsel a similar journey to any onocertainly not to a woman.

As we ascended the Hudson in the night, $I$ lost, of course, the view of that supurb scenery which I was assured even winter could not divest of all its beauty - rather clothed it in a different kind of beanty. At the very first blush of morning, I escaped from the heated cabin, erowded with listless women and clamorous children, and found my way to the deck. I was surprised by a spectacle as beautiful as it was new to me. The Catskill mountains which we had left bebind us in the night, were still visible, but just melting from the view, robed in a misty purple light, while our magnificent steamerthe prow armed with a sharp iron sheath for the purpose-was crashing its way through solid ice four inches thick, which seemed to close behind us into an adhesive mass, so that the wake of the vessel was not distinguished a few yards from the stern : yet in the path thus opened, and only seemingly closed, followed at some littledistance $a$ beautiful schooner and two smaller steam-vessels. I walked up and down, from the prow to the stern, refreshed by the keen frosty air, and the excitement caused by various picturesque effects, on the ice-bound river and the frozen shores, till we reached Hudson. Beyond this town it was not safe for the boat to advance, and we were still thirty miles below Albany. After leaving Hudson, (with the exception of the rail-road between Albany 
and Utica,) it was all heary, weary work; the most painfully fatiguing journey I ever remember. Such were the roads, that we were once six hours going eleven miles. What was usually a day's journey from one town, or one good inn to another, occupied sometimes a day and a night, or even two days.

One dark night, I remember, as the sleet and rain were falling fast and our Extra was slowly dragged by wretched brutes of horses through what seemed to me "sloughs of despond," some package ill stowed on the roof, which in the American stages presents no resting-place either for man or box, fell off. The driver alighted to fish it out of the mud. As there was some delay, a gentleman seated opposite to me put his head out of the window to inquire the cause; to whom the driver's voice replied, in an angry tone, “ I say you, mister, don't you sit jabbering there, but lend a hand to heave these things aboard!" To my surprise, the gentleman did not appear struck by the insolence of this summons, but immediately jumped out and lent his assistance. This is merely the manner of the people; the driver intended no insolence, nor was it taken as such, and my fellow-travellers could not belp laughing at my surprise.

After six days and three nights of this travelling, unrelieved by companionship, or-interest of any kind, I began to sink with fatigue. The first thing that roused me was our arrival at the ferry of the Niagara river, at Queenston, about seven miles below the Falls. It was a dark night, and while our little boat was tossed in the eddying waters, and 
guided by a light to the opposite shore, we could distinctly hear the deep roar of the cataract, filling, and, as it seemed to me, shaking the atmosphere around us. That mighty cataract, the dream and vision of my childbood and youth, so near-yet unseen-making itself thus heard and felt-like Job's vision, consciously present, yet unrevealed and undiscerned! You may believe that I woke up very decidedly from my lethargy of weariness to listen to that mysterious voice, which made my blood pause and thrill. At Queenston we slept, and proceeded next morning to the town of.Niagara on the shore of Lake Ontario. Now, as we had heard, the navigation on the lake had ceased, and we looked for nothing better than a further journey of one hundred miles round the head of the lake, and by the most execrable roads, instead of an easy passage of thirty miles across from shore to shore. But Fortune, seized with one of those freaks which, when we meet them in books, we pronounce improbable and unnatural, (and she has played me many such, some good, some bad,) had ordered matters otherwise. A steam-vessel, making a last trip, had called accidentally at the port, and was just going off; the paddles were actually in motion as I and my baggage together were hurried-almost flung-on board. No sooner there, than I threw myself down in the cabin utterly overwhelmed with fatigue, and sank at once into a profound and dreamless sleep.

How long I slept I knew not: they roused me suddenly to tell me we were at Toronto, and, not 
very well able to stand, I hurried on deck. The wharf was utterly deserted, the arrival of the steamboat being accidental and unexpected; and as $I$ stepped out of the boat I sank ankle-deep into mud and ice. The day was intensely cold and damp; the sky lowered sulkily, laden with snow, which was just beginning to fall. Half-blinded by the sleet driven into my face and the tears which filled my eyes, I walked about a mile through a quarter of the town mean in appearance, not thickly inhabited, and to me, as yet, an unknown wilderness; and through dreary, miry ways, never much thronged, and now, by reason of the impending snowstorm, nearly solitary. I heard no voices, no quick foot-steps of men or children ; I met no familiar face, no look of welcome. I was sad at heart as a woman could be-and these were the impressions, the feelings, with which I entered the house wbich was to be called my home!

There is some need-is there not?-that I allow time for these sullen, unkindly influences to melt from my mind and heart before I judge of what I behold around me. The house-only a temporary residence while another is building-is ill provided with defences against the cold, and altogether comfortless; it has the advantage of commanding one. of the principal roads entering the town and a glimpse of the bay-but at present all objects wear one bue. Land is not distinguishable from water. I see nothing but snow heaped up against my windows, not only without but within; I bear no sound but the tinkling of sleigh-bells and the occasional 
lowing of a poor half-starved cow, that, standing up to the knees in a snow-drift, presents herself at the door of a wretched little shanty opposite, and sup plicates for her small modicum of hay.

Dec. 27.

With regard to the society, I can as yet say nothing, having seen nothing of it. All the official gentlemen bave called, and all the ladies have properly and politely left their cards : so yesterday, in a sleigh, well wrapped up in furs and buffalo robes, I set out duly to return these visits. I learned something of the geography of the town-nothing of the people. Those whom I did see, looked somewhat formal and alarmed, but they may be very excellent people for all that. I returned trembling and shuddering, chilled outwardly and inwardly, for none of uny fur defences prevailed against the frost and the current of icy air, through which we glided, or rather flew, along the smooth road.

The appearance of the town was much more cheerful than on my first landing, but still melancholy enough. There was little movement or animation; few people in the streets ; some good shops and some brick houses, but the greater number of wood. The very different appearance of the town and bay in the summer season, the blueness of the water, the brightness of the verdure, the throng of ressels, the busy crowds along the piers, were often described to me, but without conveying to my mind any very definite or cheering picture. The very 
novelty of the scene before me, by strongly impressing my imagination, seemed to shut out all power of anticipation.

The choice of this site for the capital of the Upper Province was decided by the fine harbor, the only one between Burlington Bay and Cobourg, a distance of about a hundred and fifty miles. General Simcoe, the first governor after the division of the two provinces, and a man of great activity and energy of character, entertained the idea of founding a metropolis. At that time the head quarters of the government were at Niagara, then called Newark, on the opposite shore; but this was too near the frontiers to be a safe position. Nor is Toronto much safer : from its low situation, and the want of any commanding height in the neighborhood, it is nearly defenceless. In case of a war with America, a few boats sent from the opposite coast of New-York could easily lay the fort and town in ashes; and, in fact, during the last war, in 1813, such was the fate of both. But the same reasons which rendered the place indefensible to us, rendered it untenable for the enemy, and it was immediately evacuated. Another objection was, and $i s$, the unhealthiness of its situation,-in a low swamp not yet wholly drained, and with large portions of uncleared land immediately round it : still the beauty and safety of the spacious harbor, and its central position about halfway between Lake Huron and the frontier line of Lower Canada, have fixed its rank as capital of the province and the seat of the legislature.

When the engineer, Bouchette, was sent by Ge- 
neral Simcoe to survey the vito, (in 1793,) it was a mere swamp, a tangled wilderness; the birch, the hemlock and the tamaractrees were growing down to the water's edge, and even into the lake. I bare been told that Toronto, the Indian appellation of the whole district, signifies trees gronoing ont of roater. Colonel Bouchette says, that at this time the only vestige of humanity for a hundred miles on every side, was one solitary wigwam on the shrse, the dwelling of a few Missassagua Indians. Three years afterwards, when the Duc de Rochefoucauld Was here, the infant metropolis consisted of a fort and twelve miserable log huts, the inbshitants of which, as the duke tells us, bore no gord reprutation. The town was, however, already marked ont in streets running parallel with the shrore of the bay fros about two miles, and crossed by others at right angles. It is a pity that while they were abrut it, they did not follow the example of the Americans, in such cases, and make the principal streets of ample width; some bundred feet, or eren furlonges, more or less, would have made liule difference where the wild unowned forest extended, for all they knew, from the lake to the north prole- mons, it would be so easy to amend the error. Kingstreet, the principal street, looks narrow, and will look narrower when the houses are higher, better, and more regularly built. I perceive that in laying out the fashionable or westend of the city, they have aroided the same mistake. A wide space between the building lots and Lake Ontario bas been reserved very properly as a road or esplanade, 
but I doubt whether even this be wide enough. One of the most curious and inexplicable phenomena connected with these immense inland seas is the gradual rise of the waters ; and even within these fow years, as I am informed, great part of the high bank has been washed away, and a carriage-road at the foot of it along the shore has been wholly corered. If this process goes on, and at the same rate, there must be a solid embankment, or quay, raised as a barrier against the encroaching waters, or the esplanade itself will in time disappear.

Thus much of knowledge I gained in the course of my cold drive-bitter cold it was every way, and I returned without being much comforted or edified by my visits.

New Year's Day-colder than ever. This morning the thermometer stood at eighteen degrees below zero, and Dr. R- told me that some chemical compounds in his laboratory had frozen in the - night, and burst the phials in which they were contained.

They bave here at Toronto the custom which prevails in France, Germany, the United States, (more or less every where, I believe, but in England,) of paying visits of congratulation on the first day of the year. This custom, which does not apparently harmonize with the manners of the people, has been borrowed from the French inhabitants of Lower Canada.

I received this morning about thirty gentlemen- 
to gentlemen luckily for me the obligation is confined-two thinds of whom I had nerer seen nor heard of before, nor was there ang one to introduce them. Some of them, on being ustered into the room, bowed, sat down, and after the lapse of two minutes, rose and bowed themselves out of the room again without uttering a sy!labie; all were tco much in a hurry and apparent!y far too coid to converse. Those who did speak, complained, sensibly enough, of the unmeaning duty imprsed on them, and the danger incurred by running in and out from the over-heated rooms into the fierce biting air, and prophesied to themselves and others sore throats, and agues, and ferers, and every ill that flesh is beir to. I could but believe and condole. These strange faces appeared and disappeared in succession so rapidly, that I was almost giddy, bot there were one or two among the number, whom eren in fire minutes' conversation I distinguished at once as superior to the rest, and original minded, thinking men.

In London society I met with many men whose real material of mind it was difficult to discovereither they had been smoothed and polisbed down by society, or education had overlaid their nnderstanding with stuccoed ornaments, and figures bistorical and poetical-very pretty to look at-but the coarse brick-work or the rotten lath and plaster lay underneath; there being in this new country far less of conventional manner, it was.80 much the easier to tell at once the brick from the granite and the marble. 
Jan. 12.

We have had another considerable fall of snow, and the weather is milder. They say here that the weather never remains the same for more than three days together; and all agree that the atmospherical changes are violent and sudden at all seasons. Yet the medical men assure me that the climate of Canada, take it altogether, is one of the healthiest in the world, though the immediate vicinity of Toronto be for the present, from local circumstances, an exception. The winter in the upper province is infinitely less severe and trying than the same season in Lower Canada.

Jan. 14.

It should seem that this wintry season, which appears to me so dismal, is for the Canadians the season of festivity, and if I were not sick and a strangerif I had friends near me, I should really enjoy it. Now is the time for visiting, for sleighing excursions, for all intercourse of business and friendship, for balls in town, and dances in farm-houses, and courtships and marriages, and prayer-meetings and assignations of all sorts. In summer, the heat and the mosquitos render travelling disagreeable at best; in spring the roads are absolutely impassable; in autumn there is too much agricultural occupation; but in winter the forests are pervious; the roads present a smooth surface of dazzling snow; the settlers in the woods drive into the towns, supply themselves with stores and clothing, and fresh meat, 
the latter a luxury which they can seldom obtain in the summer. I stood at my window to-day watch. ing the sleighs as they glided past. They are of all shapes and sizes. A few of the carriage-sleighs are well appointed and handsome. The market-sleighs are often two or three boards nailed together in form of a wooden box upon runners; some straw and a buffalo skin or blanket serve for the seat ; barrels of flour and baskets of eggs fill up the empty space. Others are like cars, and others, called cutters, are mounted on high runners, like sleigh phaetons; these are sported by the young men and offcers of the garrison, and require no inconsiderable skill in driving; however, as I am assured, they are overturned in the snow not above once in a quarter of an hour, and no harm and much mirth ensues; but the wood sleighs are my delight : a large platform of boards is raised upon runners, with a few upright poles held together at top by a rope, the logs of oak, pine, and maple, are then heaped up to the height of six or seven feet. On the summit lie a couple of deer frozen stiff, their huge antlers projecting in a most picturesque fashion, and on these again, a man is seated with a blanket round him, his furred cap drawn down upon his ears, and his scarlet woollen comforter forming a fine bit of color. He guides with a pole his two patient oxen, the clouds of vapor curling from their nostrils into the keen frosty air-the whole machine, in short, as wildly picturesque as the grape wagons in Italy, though, to be sure, the associations are somewhat different. 
Jan. 16.

This morning, before I was quite dressed, a singular visit was announced. I had expressed to $\mathrm{my}$ friend Mr. Hepburne a wish to see some of the aborigines of the country; he bad the kindness to remember my request, and Colonel Givins, the principal Indian agent, had accordingly brought some Indians to visit us. Those to whom the appearance of these people is familiar and by no means interesting, were surprised by a curiosity which you will at least allow was very natural and feminine.

The party consisted of three-a chief named the White Deer, and two of his friends. The chief wore a blanket coat, and leggings, and a blanket hood with a peak from which depended a long black eagle plume; stout mocazins or shoes of undressed deer-skin completed his attire; he had about fifty strings of blue wampum round his neck. The othet two were similarly dressed, with the exception of the wampum and the feathers. Before I went down I had thrown a chain of wampum round my neck, which seemed to please them. Chairs being presented, they sat down at once, (though, as Colonel Givins said, they would certainly have preferred the floor,) and answered with a grave and quiet dignity the compliments and questions addressed to them. Their deportment was taciturn and self-possessed, and their countenances melancholy; that of the chief was by far the most intelligent. They informed me that they were Chippewas from the neighborhood of Lake Huron; that the hunting season had been unsuccessful; that their tribe was suffering the ex- 


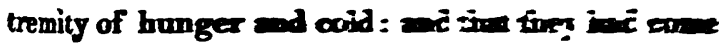

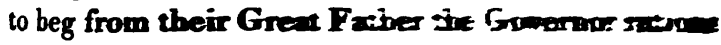

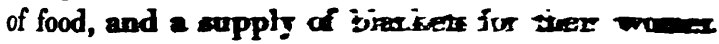

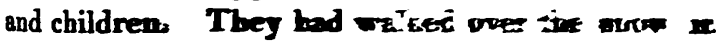
their snow-shoes, from the ifke. one inammic ic

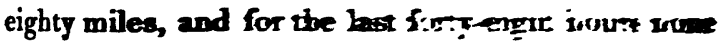

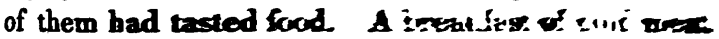

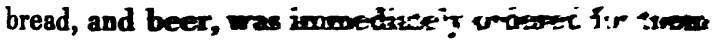

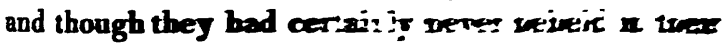

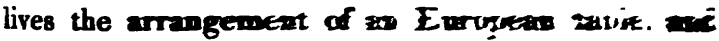
were besides half farisbod. tiver bre ritrez writ w-

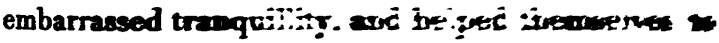

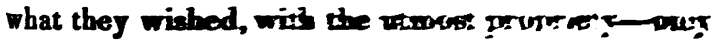
after one or two trink, asing tiver ow turee

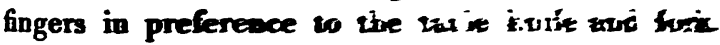

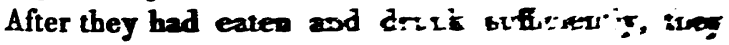

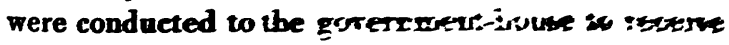

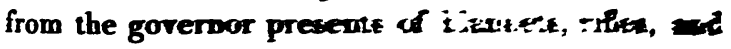

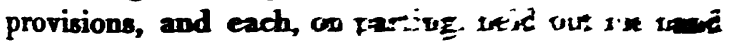

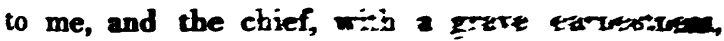
prayed for the blessing of the 6 and my house. On the wir.je, int ixy"uin ing left, though amusing and excidig s:un its

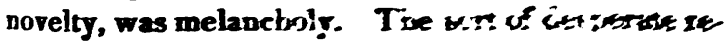

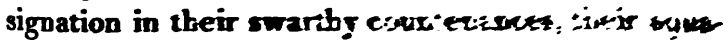

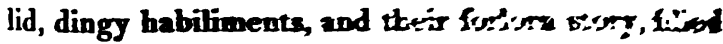
me with pity, and, I may add, diecpopoistrsent; ad all my previous impressions of tive iulepoudent children of the forest are for the present disurtwal These are the firs specimens I bave ocen of that fated race, with which I hope to become boter se quainted before I leave the covotry. Naturith

rok. 1. 
standing all I bave heard and read, I have yet but a vague idea of the Indian character; and the very differest aspect under which it has been represented by various travellers, as well as writers of fiction, adds to the difficulty of forming a correct estimate of the people, and more particularly of the true - position of their women. Colonel Givins, who has passed thirty years of his life among the northwest tribes, till he has become in babits and language almost identified with them, is hardly an impartial judge. He was their interpreter on this occasion, and he says that there is as much difference between the customs and language of differont nations, the Chippewas and Mohawks, for instance, as there is between any two nations of Europe.

January 16.

Some philosopher has said or written, that our good and bad qualities, our virtues and our vices, depend more on the influence of climate, than the pride of civilized humanity would be willing to allow; and this is a truth or truism, which for my own part I cannot gainsay-yet which I do not much like to believe. Whatever may be the climate in which the human being is born or reared, can be not always by moral strength raise himself above its degrading, or benumbing, or exciting influence? and yet more, rather than less, easily, when, at a mature age and with habits formed, he is subjected accidentally to such influences? Is 
there most wisdom, in such a case, in passively assimilating ourselves, our habits, and our feelings, to external circumstances, or resisting and combating them, rather to defend the integrity of our own individual being, than with the hope of changing or controlling the physical or social influences around us ?

How I might have settled this question with myself, long ago, when in possession of the health and energy and trusting spirit of my young years, I know-but now it is too late. I could almost wish myself a dormouse, or a she-bear, to sleep away the rest of this cold, cold winter, and wake only with the first green leaves, the first warm breath of the summer wind. I shiver through the day and through the night; and, like poor Harry Gill, "my teeth they chatter, chatter still;" and then at intervals I am burned up with a dry hot fever: this is what my maid, a good little Oxfordshire girl, calls the hager, (the ague,) more properly the lake fever, or cold fever. From the particular situation of Toronto, the disorder is very prevalent here in the spring : being a stranger, and not yet acclimatée, it has attacked me thus unseasonably. Bark is the general and unfailing remedy.

The cold is at this time so intense, that the ink freezes while I write, and my fingers stiffen round the pen; a glass of water by my bed-side, within a few feet of the hearth, (heaped with logs of oak and maple kept burning all night long,) is a solid mass of ice in the morning. God help the poor emigrants who are yet unprepared against the rigor of the 
season!-yet this is nothing to the climate of the lower province, where, as we hear, the thermometer has been thirty degrees below zero. I lose all heart to write home, or to register a reflection or a feeling; - thought stagnates in my head as the ink in my pen-and this will never do!-I must rouse myself to occupation; and if I cannot find it without, I must create it from within. There are yet four months of winter and leisure to be disposed of. How ?-I know not; - but they must be employed, not wholly lost.

The House of Assembly is now sitting, and the question at present agitated is the appropriation of the clergy reserves-a question momentous to the future welfare of the colony, and interesting to every thinking mind. There are great differences of opinion, and a good deal of bitterness of spirit, prevailing on this subject, so often brought under discussion, and as yet unsettled. When Upper Canada was separated from the Lower Province (in 1791) one-seventh part of the lands was set apart for the maintenance of the clergy, under the name of Clergy Reserves; and the Church of England, as being the church by law established, claimed the entire appropriation of these lands. The Roman Catholics, under the old conditions by which the maintenance of their church was provided for on the conquest of the colony, also put in their claim, as did the Presbyterians on account of their influence, and the Methodists on accuunt of their num- 
ber. The inhabitants, mean time, through the legislature, petitioned the government that the whole of the clergy reserves should be appropriated to the purposes of education, for which the funds already provided are wholly inadequate, and are ill manzze 1 besides-but of this hereafter. If the ques:ion $i=d$ been left to be settled by the House of Asser: :then sitting, the Radicals of 1832 , there is nos $\dot{c}$ '. that such would have been the destination of isse reserves, which now consist of about two m:..: ise of acres out of fourteen millions, set:led or in ers.se of cultivation, and indefinitely increasing as Ex.se and more land is redeemed from the unmest sest interminable forest. The government at $k, z=3, s=3$ over to the legislature here a cession of the cr'sas lands, and a recommendation to setx.e the wirice question; but we have now a House of Awss:., differently constituted from that of 1532, and exis preponderance is altogether the other way. I an now aware that there exist three parties subject :

First, those who would approprizte the whine of these reserves solely to the maintenasse of tive Church of England. This is a emali but zeaims party-not so much insisting on their sown elairs, on the absolute inconsistency and unrighters.ten of allowing any other claim. The Chareh of Prove land, as the archdeacon observed last vigt:t, inives the only true charch, as well as the chureb ky baw established, to maintain any other religirm in form of religion, at the expense of the state, is a massifem rebellion againat both the gaped and the lax. 
A second party represent that the Church of England consists of but a small number of the colonists ; that as no profession of belief (Quakerism excepted) can exclude a man from the provincial legislature, so each religion tolerated by the state should be by the state maintained. They exclaim against disuniting religion and education, and insist that the reserves should be divided in shares proportionate to the number of members of each church -among the Episcopalians, Presbyterians, Roman Catholics, Wesleyan Methodists, and Baptists. This party is numerous, but not unanimous. In hostility to the exclusive pretensions of the episcopal church they are agreed, but they seem to agree in nothing else; and some numerous and respectable sects are altogether excluded.

A third party, and by far the most numerbus, require that the maintenance of the clergy should be left, as in the United States, to the voluntary aid of their congregation, and the entire produce of the lands reserved for the education of the people.

I bave not been long enough in the country to consider the question practically, as applying to the peculiar wants and cireumstances of the people; but theoretically I do not agree with any of these parties, and at present am content to listen to all I bear around me. With regard to the petition for warded to the home government, it has been an ample sonrce of ridicule that a house of parliament, of which many members could not read, and many more could not spell, should be thus zealous on the subject of education. In truth, I have seen some 
specimens of the wriving and speiting $\alpha$ insmarame members, men of iniluesce and pripows 2506 which it was impossible not to iengi : Jue I fet in disposition to join in the rïicsie freit iess:rwsec on the writers : it seemed axt that men who had not thezséres rot:rec in io

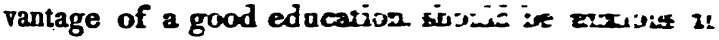
insure it to their chïdren Mr. E 1 is

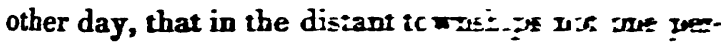
Bon in twenty or thirty coinci reac ar w:Et of rac the means of attaining soci is:-win

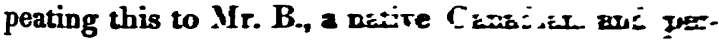
fectly acquainted with the conftry. pression of incredulity, be excizint ingulug "Not one in twenty or thing! - Mainitr use we II seventy !"

The question, as a mere party quesion, $\hat{c}_{i} \overline{\text { suc }}$ interest me; but the strange, crude, igu Jesut ragut opinions I heard in conversatior, and rond in in debates and the provincial papers, excrec irg ancer nishment. It struck we thet if I covid tive English preface to Victor Consin's report it wiont I had a copy) printed in a cheap form, and cince lated with the newspapers, adding some of the statistical calculations, and some pases from Duppa's report on the eduction of the chadren of the poorer classes, it might do some good-it mighe assist the people to some general principles of which to form opinions; whereas they all appesed to me astray, nothing that had bees promulgsed in Europe on this momentors sabjects bat yet reached them; and the brevity and cleareas of 
this little preface, which exhibits the importance of a system of national education, and some general truths without admixture of any political or sectarian bias, would, I thought-1 hoped-obtain for it a favorable reception. But, no; cold water was thrown upon me from every side-my interference in any way was so visibly distasteful, that I gave my project up with many a sigh, and I am afraid I shall always regret this. True, I am yet a strangerhelpless as to means, and feeling my way in a social system of which I know little or nothing; perhaps I might have done more mischief than good-who knows? and truth is sure to prevail at last; but truth seems to find so much difficulty in crossing the Atlantic, that one would think she was "like the poor cat $i$ ' the adage," afraid of wetting her feet.

Another fit of illness and fever of four days' duration happily over; but it has left me more good-for-nothing than ever-more dejected and weak.

Mr. Campbell, the clerk of the assize, has politely offered to drive me over to Niagara in his sleigh. Good-natured Mr. Campbell! I never saw the man in my life; but, in the excess of my gratitude, am ready to believe him every thing that is delightful; my heart was dying within me, gasping and panting for change of some kind-any kind! I suppose from the same sort of instinct which sends the 
wounded animal into the forest to seek for the berb which shall heal him. For bere is Dr. $R$, who a ares me that change of air is the only thing wbicb can counteract the effect of these successive fits of aguish fever: so it is fixed that on Tuesday pert, at eight o'clock in the moming, I shall be ready to step into Mr. Campbell's sleigh. Fire dars-fire times twenty-four hours of frost and snow withou, and monotonous solitude within-and my faccitien, and my fingers, and my ink, all frozen op !

"So slow the onprofitable moonents $\mathrm{ra}_{3}$ That lock up all the funcions of $5 \mathrm{y}$ son!, That keep me from myseif"

Slow?-yes; but why unprofitable? that were surely my own fault !

Janzery 21.

There is some diminution of the intense coid yesterday and to-day. The thermometer is abore zero.

$I$ begin to be ashamed of recording idle days and useless days, and to have a conception of what those unfortunate wretcbes must suffer, who are habitually without an interest and without an occupation. What a life is this!

a Life which the very stars reprove, As on their silent tasks they move."

To mo it is something new, for I baro never yot 
beon ennuyéc to death-except in fiction. It is like the old-fashioned torture patronized by that amiable person, Queen Elizabeth, when a certain weight was placed on the bosom of the criminal, and increased gradually every day till the life and the heart were crushed together. Well! patience and resignation are still at hand :-but Patience, " the young and rose-lipped cherubim," seems to have borrowed the features of grim Necessity, and, instead of singing an angel's song, clanks her fetters In my ear; and Resignation comes in a form which reminds me of Ottilie's definition- " Resignation, my dear, is only a despair, which does not beat people." Yet there remains Duty, which is, far more than Love-

: . "The star to every wandering bark,

That looks on tempests, and is never shaken."

It is the upholding law through which the weakest become strong, without which all strength is unstable as water. No character, however harmoniously framed and gloriously gifted, can be complete without this abiding principle; it is the cement which binds the whole moral edifice together, without which all power, goodness, intellect, truth, happiness, love itself, can have no permanence; but all the fabric of existence crumbles away from under us, and leaves us at last sitting in the midst of a ruin-astonished at our own desolation. 
Januery 21-22.

While ranging my German books this morning, I fell upon the Correggio of Oeblenschlager, ard $V_{i e}$ Schuld of Mallner; and I read both through care fully. The former pleased me more, the latter aruck me less, than when I read them both for the frst time a year ago.

One despairs of nothing since the success of "I $r_{x} ; "$ but would it be possible, thiuk you, that the trazedy of " Correggio" could be exhibited in Engard " any thing like the success it met with in Gerwas! ? Here-in England I mean-it might indered " fut audience find, though few," but would it west is the same sympathy?-would it even be exdssed with common patience by a mixed andience-sin.s as hailed its appearance in Germany ?

Here is a tragedy, of which the pervadisg is terest is not low ambition and the pride of kis-za; nor love, nor terror, nor murder, nor the rivina is princes, nor the fall of dynasties, wr any of usual forms of tragic incident-but $\triangle R T$, bi.t. an its power as developed within the indiridwi, w, , its influence on the minds of cthen. This embodied in the character of Correggivs: yot is no abstraction, but perfectly individualized. A.l those traits of his life and peculiar batsits ata d.xpr sition, banded down by tradition, are mont casct aijy preserved, and the result is a mont adruiration pre. trait of the artist and the man. His gention, him tenderness, his sensitive modesty, bis swet, kring, retiring disposition, are all toucbed wish expluimita delicacy. The out-break of poble selfecuradersen, 
when he exclaimed, after gazing on Raffaelle's St. Cecilia, "Anch' io sono Pittore I" is beautifully introduced. The sight of the same picture sent $\mathrm{La}$ Francia home to his bed to die, so at least it is said; but Correggio was not a man to die of another's excellence, though too often doubting his own. The anecdote of the man who was saved from the rapacity and vengeance of a robber, by an appeal to one of his pictures, and the story of his paying his apothecary with one of his finest works," are also real incidents of the painter's life, introduced with the most picturesque effect.

Those who have travelled through the forests of Catbolic Germany and Italy, must often have seen a Madonna, or a Magdalen, in a rude frame, shrined against the knotted trunk of an old oak overshadowing the path; the green grass waving round, a votive wreath of wild flowers hung upon the rude shrine, and in front a little space worn bare by the knees of travellers who have turned aside from their journey to rest in the cool shade, and put up an Ave Maria, or an Ora pro nobis. I well remember once coming on such a Madonna in a wild woodland path near Vollbrücken, in Upper Austria. Two little, half-naked children, and a gaunt, black-bearded wood-cutter, were kneeling before it; and from afar the songs of some peasants gathering in the harvest were born on the air. The Magdalen of Correggio, the same which is now in the Dresden gallery, and multiplied in prints and copies through

- The Christ on the Mount of Olives, now, if I remember rightly, in posseasion of the Duke of Wellington. 
the known world, is represented without any violent stretch of probability as occupying such a situation : nor are we left in doubt as to the identity of the picture; it is described in three or four exquisite lines. It is beautiful-is it not?-where Correggio comments on his work, as he is presenting it to the old hermit :
"Ein sündhaft Mādehen, das mit Reu' und Angst
Wie ein gescheuchtes Reh zum Dickicht floh,
Um der nachstellung ferner zu entgehen.
Doch ist es schön von einem Weibe, meyn ich,
Einmal gefallen wieder sich zu heben;
Es gibt sehr wen'ge Mānner, die das können."*

And the reply of Silvestro places the lovely form before us, painted in words.

\section{Welch schön Gemählde !}

Der dunkle Schattenwald, die blonden Haare,

Die weisse Haut, das himmel blau Gewand

Die Jugendfülle und der Todtenkopf,

Das Weiberhafte und das grosse Buch,

Ihr habt mit vieler Kunst die Gegensätze

In schöner Harmonie heir auf-gelöst."†

- An erring maiden, that in fear and penitence

Flies, like timid hind, to the deep woods,

Seeking t'escape the snares around her laidAnd it is good to see a hapless woman

That has once fallen redeem herself :-in truth,

There be few men methinks could do as much.

What a fair picture!

Thisdark o'er-hanging shade, the long fair hair,

The delieate white-skin, the dark blue robe,

The full luxuriant life, the grim death's head,

The tender womanhood, and the great book-

vos. 1. 
The manner in which Correggio betrays his regret on parting with his picture, is also natural and most exquisite.

“ Die Dichter haben's gat; síe können immer

Die Kinder alle in der Nähe haben.

Ber Mahler ist ein armer Vuter, der

Sie in die weite Welt aussenden muss ;

Da müssen sie nachher sich selbst versorgen." *

Grouped around Correggio in every possible degree of harmony and contrast, we have a variety of figures all sufficiently marked, each in itself complete, and all aiding in carrying out the main effect, the apotheosis of the artist hero.

Nor has Oeblenschläger made his tragedy the rehicle for mere declamation, nor for inculcating any particular system of art or set of principles. In Michael Angelo and in Giulio Romano we have exhibited two artist-minds as different from each other and from Antonio Correggio as can be imagined. The haughty, stern, arrogant, but magnanimous and magnificent Michael Angelo, can with difficulty be brought to appreciate, or even look upon a style so different from his own, and thunders out his rules of art like Olympian Jove. The gay, confident, gene-

These various contrasts have you cunningly

Brought into sweetest harmony.

- Well for the poet I he can ever have

The children of his soul beside him here;

The painter is a needy father; he

Sends his poor children out in the wide world

To seek their fortune. 
rous, courteous Giulio Romano is less exclusive, if less severely grand, in his taste. The luxuriant grace of Correggio, the blending of the purely na. tural with the purely ideal, in his conceptions of beauty, are again distinct from both these great masters. Again the influence of art over minds variously constituted is exhibited in the tender wife of Correggie, the favurite model for his Madonnas : the old hermit Silvestro; the high-born, beautiful enthusiast, Celestina, who places the laurel-wreath on the brow of the sleeping painter : and the peasant girl, Lauretta, who gives him drink when fainting with thirst; and the penitent robber; and the careless young noble, with whom art is subservient to his vanity and his passions; and the vulgar villain of the piece, Battista, who alone is absolutely insensible to its infuence;-all these form as beautiful a group, and as perfect in keeping, as we can meet in dramatic literature. Then there are such charming touches of feeling, stuch splendid passages of description and apherisms on art, which seize on the fancy and cling to the memory! while the allusions to certain well-known pictures, bringing them before the mind's eye in a few expressive and characteristic words, are delicious to the amateur.

The received account of the cause of Correggio's death rests on a tradition," which later researches

- That of Vasari, who states that he died in extreme poverty; that, having reeeived at Parma a payment of sixty crowns, which was churlishly made to hin in copper, he walked to the city of Correggio with this load on his back from anxiety to relieve his family, and died in consequence of the effort. Lanzi 
fender very problematical; but it remains uncostradicted that he lived and died poor-that his bealth was feeble and delicato-his life rotired and blameless; and the catastrophe has been so long current and credited, that the poet has done well to adbere to the common tradition. In the very moment that Correggio sinks into death, a messenger arrives from the Duke of Mantua, with splendid offers of patronage. He comes too late. Art and the world are the heirs of the great man's genius; his poor family fol. low him heart-braken to the grave.

The Schuld of Adolf Mülner does not produce such an overpowering effect on the imagination the second time of reading, because we are not hurried forward by the interest of the story ; but in one respect it has affected me more deeply than at first. Hugo says,

" Mich dunket, nie

Sollten Nord und Süd sich küssen !"*

And all through this fine play the spirit of the North and the spirit of the South are brought into beautiful yet fearful contrast. The passions which form the groundwork of the piece are prepared amid the palaces and orange-groves of the glowing South: the catastrophe evolved amid the deserts and pine-

and other of his biographers distrust this story, and have pointed out its improbability. Whatever the cause of his death, the expressions of Annibal Carracci are conclusive as to the neglect and poverty in which he lived.

* Methinks,

That North and South should never kiss each other. 
forests of the North; and in the fair, still-souled, but heraic Scandinavian maid, Jerta, and the dark, impassioned Elvira, we have the pernonified sentiment of the North and the South:

Has it ever occurred to you that Coleridge must have had this tragedy in his mind when he wrote his "Remorse?"

What a slight touch upon an extreme link will send us back sometimes through a long, long chain of memories and associations! A word, a name, has sent me from Toronto to Vienna ; what a flight ! what a contrast!-it makes even Fancy herself breathless! Did I ever mention to you Madame Arneth ! When the "Schuld" was produced at Vienna, she played the Scandinavian Jerta, and I bave heard the effect of her representation compared, in its characteristic purity and calmness, and mild intellectual beauty, to the "moonlight on a snow-wreath"- a comparison which gave me a vivid impression of its truth. Madame Arneth was her: self not unlike the fair and serious Jerta.

The question has been often agitated, often controverteds but I am inclined to maintain the opinion elsewhere expressed, that there is nothing in the profession of an actress which is incompatible with the respect due to us as women-the cultivation of etery feminine virtue-the practice of every private duty. I have conversed with those who think ottrerwise, and yet continue to frequent the theatre as an amusement, and even as a source of mental de. light and improvement; and this I cotceite to be a dereliction of principle-wrong in itself, and

vor. 1. 
the cause of wrong. A love for dramatic repres entation, for imitative aetion, is in the elements of our human nature; we see it in children, in savages, in all ages, in all nations;-we cannot help it-it is even so. That the position of an actress should sometimes be a false one-a dangerous one even for a female, is not the fault of the profession, but the effect of the public opinion of the profession. When fashion, or conventional law, or public opinian, denounce as inexpedient what they cannot prove to be wrong-stigmatize what they allowencourage and take delight in what they affect to contemn-what wonder that from such barbarous, such senseless inconsistency, should spring a whole heap of abuses and mistakes? As to the idea that acting, as a profession, is incompatible with female virtue and modesty, it is not merely an insult to the estimable women who have adorned and still adorn the stage, but to all womankind; it makes me blush with indignation. Unreflecting people-the world is full of such-point to the numerous instances which might be cited to the contrary. I have been perplexed by them sometimes in argument, but never on consideration and examination; and with regard to some other evils, not less, as it appears to me, in a moral point of view, I do not see their ne cessary connexion with the stage as a profession Vanity, jealousy, seltishness, the spirit of intrigue, the morbid effects of over-excitement, are not con fined to actresses; if women placed in this position do require caution and dignity to ward off temptatiogn and selff-control to, resist ịt, and some know- 
ledge of their own structure and the liabilities incurred by their profession, in order to manage better their own bealth, moral and physical, then they Jnly require what all women should possess-what every woman needs, no matter what her position.

But to return to Madame Arneth.

At Vienna, some years ago, there lived three celebrated actresses, all beautiful, and young, and gifted. Sophie Muller was first mentioned to me by Schlegel; he spoke of her with rapturous admiration as the most successful representative of some of Shakspeare's characters that had yet been seen in Germany, and she seems to have left an ineffaceble impression on those who saw her play Chrimhilde in the "Niebelung." She was surrounded by admirers, adorers, yet I never heard that one among them could boast of being distinguished even by a preference; austere to herself, devoted to her art, which she studied assiduously, her ambition centered in it; in the mean time she was performing all the duties of a daughter to an aged father, and of a mother to a family of younger brothers and sisters; and her house was a model of good order and propriety. She died in 1830.

Not long before died Anna Krüger, equally blameless in ber conduct and reputation as a woman, but in all other respects negligent of herself and of her own interests. She was remarkably free from all selfishness or jealousy, charitable and good, and universally beloved. Her representation of spirited or heroic characters, in comedy and in tragedy, has 
been described to me as wonderfully fine. Schiller's Joan of Arc was her chef d'auvre.

The third was Antoinette Adamberger, now Madame Arneth, whom I am happy and proud to number among my friends. Her former name cannot be unknuwn to you, for it has a dear yet melancholy celebrity throughout all Germany, and is inseparably associated with the literature of her country, as the betrothed bride of Theodore Korner, the poet-hero of the war of deliverance. It was not till we had been for some time intimate that $I$ ever heard her allude to Körner. One evening as we were sitting alone, she gave me, with much feeling and graphic power, and even more simplicity, some particulars of her first interview with him, and the circumstances which led to their engagement. I should tell you that she was at the time a favorite actress of the Court Theatre, and excelled particularly in all characters that required more of delicacy, and grace, and dignity, than of power and passion; those of Thekla in the "Wallenstein," and Jerta in the "Schuld," being considered as her masterpieces. Of her judgment as an artiste I could form some idea, from an analysis into which 1 once tempted her of theBeatrice in Schiller's " Braut von Messina," a character in which she is said to have excelled, and which, in its tender delicacy and almost evanescent grace, might be compared to Perdita. To analyze all the passive beauty and power of Schiller's conception, must have required a just and exquisite taste, and to render them with such felicity and effect, a person corresponding in irlish deli- 
cacy. Yet, perhaps, in her youthful years, when she played Beatrice divinely, Madame Arneth could not have analyzed the character as ingeniously as she did when a ripened judgment and more cultivated taste enabled her to reflect on her own conception. This, however, is digressing; for the moral qualities, not the intellectual powers, of the actress, are what I am contending for. Theodore Korner came to Vienna in 1813 , bringing with him his " Grüne Domino," a piece composed expressly or Anna Krüger and Antoinette Adamberger. These two young women, differing altogether in character, were united by the most tender friendship, and a sincere admiration for each other's particular talent. I have been told that it was delightful to see them play together in the same piece, the perfect understanding which existed between them producing an effect of harmony and reality which was felt, rather than perceived, by the audience. At the period of Körner's arrival, Antoinette was ill in consequence of the extreme severity of the winter of that year, and the rehearsal of the "Grune Domino" was put off from day to day, from week to week, till Körner becamo absolutely impatient. At this time he had not been introduced to Antoinette, and it was suspected that the beauty of Anna Krüger had captivated him. At length, the convalescence of the principal actress was announced, the day for the long-deferred rehearsal arrived, and the performers had assembled in the green-room. Now, it happened that in the time of the late empress,"

- Maria-Theresa-Caroline of Naples, who died in 1807. 
the representation of Schiller's "Marie Stuart" had been forbidden, because her imperial majesty had been greatly scandalized by the indecorous quarrel scene between Queen Elizabeth and Queen Mary, and particularly by the catastrophe of the latter, regarding the whole play as extremely dangerous and derogatory to all crowned heads, more especially female ones. On her death it was hoped that this prohibition would be repealed, and the performers presented a petition to that effect. The emperor, however, steadily refused, on the plea that he had promised the empress never to permit the representution of the tragedy.* The refusal had just been received, and the whole corps dramatique were in a state of commotion, and divided on the merits of the case. Korner, in particular, was ip a perfect fever of indignation, and exclaimed, in no measured terms, against the edict which deprived the public of one of Schiller's masterpieces, in tenderness to the caprices of an old woman now in her grave, et cetera. The greater number of those present sympathized with him. The dispute was at its height when Antoinette entered the room, still weak from recent illness, and wrapped up in cloaks and furs. Her comrades crowded around her with congratulations and expressions of affection, and insisted that the matter in dispute should be referred to "Toni ;" Korner, meanwhile, standing by in proud silence;

- I do not know whether the emperor was ever induced to break this promise. It was after bis death that I saw the Marie Stuart perforined at Vienna, where Madame Schroeder and Mdlle. Fuurnier appeared as Queen Elizabeth and Mary Stuart. 
be had not yet been introduced. When the affair was stated, and the opinions of the majority vehemently pressed on her, she replied in her gentle manner, "I do not pretend to judge about the injury done to the public, or the expediency or inexpediency of the matter; it is a simple question between right and wrong-between truth and falsehood. For myself, I can only say, that if I had made a promise to a person I loved, or to any one, I would keep it as long as I had life myself, and the death of that person would render such a promise not less, but more binding, more sacred, if possible."

This simple appeal to principle and truth silenced -all. Körner said no more, but his attention was fixed, and from that moment, as he told her afterwards, he loved her; his feelings were interested before he had even looked into her eyes; and it is no wonder that those eyes, when revealed, completed her conquest.

Within a few weeks they were betrothed lorers, and within a few months afterwards the patriotic war (die Freiheits-Kriege) broke out, and Korner joined Lutzow's volunteers. His fate is well known. Young and handsome, a poet and a hero, loving, and in the full assurance of being loved, with all life's fairest visions and purest affections fresh about his head and heart, he perished-the miniature of "Toni" being found within his bosom next to the little pocket-book in which he had written the Song of the Sword - the first shattered by the bullet which had found his heart, the latter stained with his blood; 
I have seen it-held it in my hand! Now, will you believe, that within three or four months afterwards, when Antoinette was under the obligation to resurme her professional duties, the first character she was ordered to play was that of Thekla? In vain she entreated to be spared this outrage to every feeling of a heart yet bleeding from her loss; the greater her reluctance, the greater the effect which would be produced on the curiosity and sympathy of the public; - this, I suppose, was the cold calculation of the directory 1 She was not excused; and after going through the scene in which the Swedish captain relates to Thekla the death of her lover, "the poor Antoinette was carried from the stage by her aunt almost lifeless, and revived only to give way to such agonies of grief and indignation as threatened her reason.

Maclame Arneth is remarkably calm and simple in her manner, and more than twenty years had elapsed since she had been thus insulted and tortured ; but when she alluded to this part of her history, she became gradually convulsed with emotion, trembled in every limb, and pressed her hands upon her eyes, from which the tears rould gush in spite of an effort to restrain them. And to this, you will say, an actress could be exposed? Yes; and I remember another instance, when under circumstances as cruel and as revolting, a young and admired actress was hurried before the public in an agony of reluctance; but still I do say, that such exhibitions are

- It $\mathbf{w i l l}$ be remembered that the death of Theodore Körner was similar to that of Max Piccodomini. 
not nocescarily or solely confined to the profescion of the stage; woman, as a legal property, is subjocted to them in her conventional position; a woman may bo brought into a church against her will, libeltod and pilloried in an audacious newspaper; an English matron may be dragged from private life into a court of justice, exposed, guiltless and helpless, to the public obloquy or the public sympathy, in shame and in despair. If such a scene cas by possibility take place, one stage is not worse than another.

Antoipette bad sufferod what a woman of a quiet but proud temper never forgets or forgires. She had made up her mind to quit the stage, and there was only ono way of doing so with honor. F́our years after the death of Korner she married Mr. Arneth, one of the directors of the Imperial Museum, a learned and amiable man, considerably older than herself," and with whom she has hived happily. Before I left Vienna she presented me with a book which Korner had given her, containing his autograph and the dramas he had written for her-"Die Toni,"

- Madame Arneth is now Vorlescrin (Reader) to the Empress Dowager, and intrusted with the direction of a school, founded by the Empress for the children of soldiers. In Austria enly two soldiers in each campany are allowed to marry, and the female children of such marriages are, in a manner, predestined to want and infamy. In the school under Madame Arneth's direction, I found (in 1835) forty-five children, well managed and healthy. The benevolence which suggested such an institution is, without doubt, praiseworthy; but what shall we say of the system which makes such an institution necessary $?$ 
"der Grane Domino," and others. I exclaimed thoughtlossly, " $O$ how can you part with it?" and she replied with a sweet seriousness, "When I married a worthy man who loved me and trusted me, 1 thought there should be no wavering of the heart between past recollections and present duties : I put this and all other objects connected with that first period of my life entirely away, and I have never looked at it since. Take it ! and believe me, eren now, it is better in your hands than in mine." And mine it shall never leave.

Madame Arneth once described to me the admirable acting of Schroeder in Medea, when playing with her own children : she treated them, however, with savage rougbness; and when remonstrated with, she replied, "the children were ber own, and she had a right to do what she liked with them." "That was certainly her affair," added Madame Arneth, " but I would not for the whole world have exhibited myself before my own children in such a character."

Is not this a woman worthy of all love, all respect, all reverence? and is not this the sentiment of duty which is, or should be, " the star to every wandering bark ?" And thus I have read and scribbled away two long days. The eve of my intended excursion is come at last; I am looking forward to to-morrow with almost childish pleasure and impatience. The weather is most ominous; but I shall see Niagara in all its wintry magnificence-a sight granted to few. $O I$ in this moment $I$ do not envy you the blue Mediterranean, nor the summer skics and orange-groves of your southern island! 
NIAGARA IN WINTER.

Merrily dash we o'er valley and hill, All but the sleigh-bell is sleeping and still;

$O$ bless the dear sleigh-bell! there's nought can compare

To its loud merry tones as they break on the ear.

Our horses are staunch, and they dash o'er the snow;

Our bells ring out gaily the faster wo go;

The night breezes sing with an answering swell

To the melody rude of the merry sleigh-bell.

Canadian Song.

\section{- January 23.}

Ar half-past eight Mr. Campbell was at the door in a very pretty commodious sleigh, in form like a barouche, with the bead up. I was absolutely buried in furs; a blanket, netted for me by the kindest hands, of the finest lamb's-wool, rich in color, and as light and elastic as it was deliciously warm, was folded round my limbs; buffalo and bear skins were heaped over all, and every breath of the external air excluded by every possible device. Mr. Oampbell drove his own gray horses; and thus fortified and accoutred, off we flew, literally "urged by storms along the slippery way," for the weather was terrific.

I think that but for this journey I never could have imagined the sublime desolation of a northern winter, and it has impressed me strongly. In the first place, the whole atmosphere appeared as if 
converted into snow, which fell in thick, tiny, starry fakes, till the buffalo robes and furs about us appeared like swansdown, and the harness on the horses of the same delicate material. The whole carth was a white waste: the road, on which the sleigh-track was only just perceptible, ran for miles in a straight line; on each side rose the dark, melancholy pine-forest, slumbering drearily in the hazy air. Between us and the edge of the forest were frequent spaces of cleared or half-cleared land, spotted over with the black charred stumps and blasted trunks of once magnificent trees, projecting from the snowdrift. These, which are perpetually recurring objects in a Canadian landscape, have a most melancholy appearance. Sometimes wide openings occurred to the left, bringing us in sight of Lake Ontario, and even in some places down upen the edge of it : in this part of the lake the enormous body of the water and its incessant movement prevents it from freezing, and the dark waves rolled in, heavily plunging on the icy shore with a sullen booming sound. A. few roods from the land, the cold gray waters, and the cold, gray, snow-encumbered atmosphere, were mingled with each other, and each seemed either. The only living thing I saw in a space of about twenty miles was a magnifcent bald-beaded eagle, which, after sailing a few turnsin advance of us, alighted on the topmost bough of a blasted pine, and slowly folding his great wide wings, looked down upon us as we glided beneath him.

The first village we passed through was Spring- 
field, on the river Credit, a river of some importance in summer, but now, converted into ice, heaped up with snow, and undistinguishable. Twenty miles further, we stopped at Oakville to refresh ourselves and the horses.

Oakville stands close upon the lake, at the mouth of a little river called Sixteen Mile Creek; it owes its existence to a gentleman of the name of Chisholm, and, from its situation and other local circumstances, bids fair to become a place of importance. In the summer it is a frequented harbor, and carries on a considerable trade in lumber, for so they characteristically call timber in this country. From its dock-yards I am told that a fine steamboat and a dozen schooners have been already launched.

In summer, the country round is rich and beautiful, with a number of farms all in a high state of cultivation; but Canada in winter and in summer must be like two different regions. At present the mouth of the creek is frozen up; all trade, all ship-building suspended. Oakville presents the appearance of a straggling hamlet, containing a few frame and logbouses; one brick house, (the grocery store, or general shop, which in a new Canadian village is always the best house in the place,) a little Methodist church, painted green and white, but as yet no resident preacher; and an inn diguified by the name of the "Oakville House Hotel." Where there is a store, a tavern, and a church, habitations soon rise around them. Oakville contains at present more than three hundred inhabitants, who are now 


\section{4}

unbecribing end a resic:

I stood c me, till I I house, bef: tho ice-bl heated lik a few vilc zines; th ding-dres "Robe d. inventée ! but too la amuseme! open, ani upon it a: "Dévine rous le dc $\omega$, while realized sarago lif. mon-place opoil it, I Iine Amur snent.

Socie That. Our ri Ridict Profes. Profes: Of Fol They's
W men

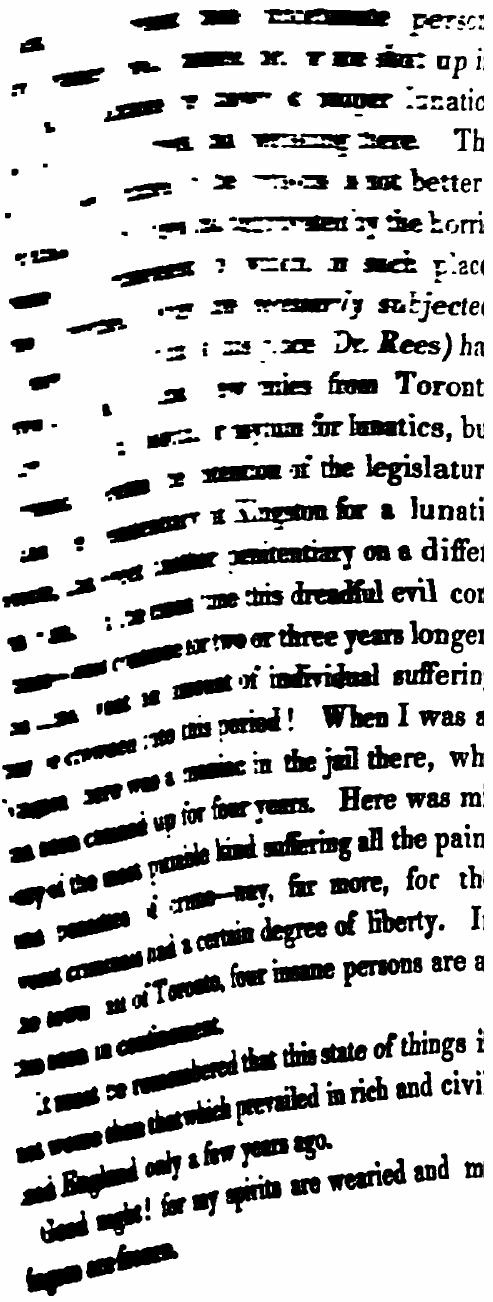


-

March 6.

As light was the eldest-born principle of the unierse, so love was the eldest-born passion of hunanity, though people quote Milton to prove that ranity was so-in our own sex at least: and many sre the witty sayings on this favorite text; but they are wrong, and their text misinterpreted. Eve, when she looked in passionate delight on her own lorely face reflected in the stream, knew not it was her own, and had nothing else to love; the moment she found an Adam on whom to lavish the awakened sympathies, she turned from the shadow to the reality, even though " less winning soft, less amiably fair:" she did not sit upon the bank and pine to death for her own fair face,

- "Like that too beauteous boy,

That lost himself by loving of himself;"

- while the voice of love wooed ber in vain. Vanity in this instance was but the shadow of love.

But, $\mathrm{O}$ me! how many women since the days of Echo and Narcissus, have pined themselves into air for the luve of men who were in love only with themselves !

Where the vivacity of the intellect and the strength of the passions, exceed the development of the moral faculties, the character is likely to bo embittered or corrupted by extremes, either of adversity or prosperity. This is especially the case vor. I. 
oubecribing among themoelves for a schoolmaster and a resident clergyman.

I stood conversing in the porch, and looking about me, till I found it necessary to seek shelter in the house, before my nose was absolutely taken off by the ice-blast. The little parlor was solitary, and heated like an oven. Against the wall were stuck a few vile prints, taken out of old American magazines; there was the Duchess de Berri in her wedding-dress, and as a pendant, the Modes de Paris"Robe de tulle garnie de fleurs-coiffure nouvelle, inventée par Mons. Plaisir." The incongruity was but too laughable! I looked round me for some amusement or occupation, and at last spied a book open, and turned down upon its face. I pounced upon it as a prize; and what do you think it was? "Dśrinez, madame! je vous le donne en trois, je rous le donne en quatre !" it was-Don Juan! And m, while looking from the window on a scene which realized all you can imagine of the desolation of savage life, mixed up with just so much of the com. mon-place vulgarity of civilized life as sufficed to spoil it, I amused myself reading of the Lady Ado lime Amundeville and her precious coterie, and there aneme.

Society is smoothed to that excess,

That manners hardly differ more than dress.

Our ridicules are kept in the back grounds -

Ridiculous enough, bot also dull;

Professions, too, are no more to be found

Professional, and there is nought to cull

Of Folly's fruit; for though your fools abound,

'They're barren and not worth the pains to pulk. 
Society is now one polished horde,

Form'd of two mighty tribes-the bores and bored.

A delineation, by the way, which might almost reconcile one to a more savage locality than that around me.

While I was reading, the mail-coach between Hamilton and Toronto drove up to the door; and because you shall understand what sort of a thing a Canadian mail is, and thereupon sympathize in my irrepressible wonder and amusement, I must sketch it for you.. It was a heavy wooden edifice, about the size and form of an old-fashioned lord mayor's coach, placed on runners, and raised about a foot from the ground; the whole was painted of a bright red, and long icicles hung from the roof. This monstrous machine disgorged from its portal eight men-creatures, all enveloped in bearskins and shaggy dreadnoughts, and pea-jackets, and fur-caps down upon their noses, looking like a procession of bears on their hind-legs, tumbling out of a showman's caravan. They proved, however, when undisguised, to be gentlemen, most of them going up to Toronto to attend their duties in the House of Assembly. One of these, a personage of remarkable beight and size, and a peculiar cast of features, was introduced to me as Mr. Kerr, the possessor of large estates in the neghborhood, partly acquired, and partly inherited from his fatherin-law, Brandt, the famous chief of the Six Nations. Kerr himself bás Indian blood in his veins. His son, young Kerr, fine boy about ten years old, is 
the present acknowledged chief of the Six Nations, in his mother's right, the hereditary chieftainship being always transmitted through the female, though passing over her. Mrs. Kerr, the eldest daughter of Brandt, is a squaw of unmixed Indian blood, and has been described to me as a very superior creature. She has the good sense to wear habitually ber Indian costume, slightly modified, in which she looks and moves a princess, graceful and unrestrained, while in a fashionable European dress the effect is exactly the reverse.

Much mischief has been done in this neighborhood by beasts of prey, and the deer, driven by hunger and the wolves from their forest haunts, have been killed, near the settlements, in unusual numbers. One of the Indians whom I saw at Toronto, on returning by this road, shot with his new rifle eight deer in one day, and sold them at Hamilton for three dollars each-no bad day's hunting. The venison in Canada is good and abundant, but very lean, very unlike English venison; the price is generally four or six cents (two pence or three pence) a pound.

After taking some refreshment, we set forth again. The next village we passed was called, oddly enough, Wellington Square; it has been recently laid out, and contains about twenty wooden houses ; then came Port Nelson, Mr. Kerr's place. Instead of going round the head of the lake by Hamilton, we crossed that very remarkable tongue or slip of land which divides Burlington Bay from Lake Ontario; these were, in fact, two separate 
lakes till a channel was cut through the narron isthmus. Burlington Bay, containing about forty square miles, is now one sheet of ice, and on the slip of land, which is near seven miles in length, and about two bundred yards in width, we found the snow lying so deep and in such irregular drifts, that we proceeded with difficulty. At length we reached Stony Creek, a village celebrated in these parts as the scene of the bloodiest battle fought between the English and Americans during the last war. We had intended to sleep here, but the inn was so uncomfortable and unpromising, that after a short rest we determined on proceeding ten miles further to Beamsville.

It was now dark, and, the snow falling thick, it oon became impossible to distinguish the sleightrack. Mr. Campbell loosened the reins and left the horses to their own instinct, assuring me it was the safest way of proceeding. After this I remember no more distinctly, except that. I ceased to hear the ever-jingling sleigh-bells. I awoke, as if from the influence of nightmare, to find the sleigh overturned, myself lying in the bottom of it half-smothered, and my companions nowbere to be seen; they were floundering in the snow behind.

Luckily, when we had stretched ourselves and shaken off the snow, we were found unhurt in life and limb. We had fallen down a bank into the bed of a rivulet, or a mill-race, I believe, which, being filled up with snow, was quite as soft, only a little colder, than a down-bed. Frightened I was, bewildered rather, but "effective" in a moment. It 
was impossible for the gentlemen to leave the borses, which were plunging furiously up to the shoulders in the snow, and had already broken the sleigh; so I set off to seek assistance, having received proper directions. Fortunately we were not far from Beamsville. My beacon-light was to be the chimney of a furge, from which the bright sparks were streaming up into the dark wintry air, viqible from a great distance. After scrambling through many a snow-drift, up hill and down hill, $I$ at last reached the forge, where a man was hammering amain at a ploughshare; such was the din, that I called for some time unheard; at last, as I advanced into the red light of the fire, the man's eyes fell upon me, and I shall never forget his look as he stood poising his hammer, with the most comical expres. sion of bewildered amazement. I could not get an answer from him; he opened his mouth and repeated aw! staring at $\mathrm{me}$, but without speaking or moving. I turned away in despair, yet balf laughing, and after some more scrambling up and down, I found myself in the village, and was directed to the inn. Assistance was immediately sent off to my friends, and in a few minutes the supper table was spread, a pile of logs higher than myself blazing away in the chimney; venison-steaks, and fried fish, coffee, hot cakes, cheese, and whiskey punch, (the traveller's fare in Canada,) were soon smoking on the table; our landlady presided, and the even. ing passed merrily away.

The old landlady of this inn amused me exceedingly; she had passed all her life among her equals 
In station and education, and had no idea of any distinction between guests and customers; and while caressing and attending on me, like an old mother or an old nurse, gave me her history, and that of all her kith and kin. Forty years before, her husband had emigrated, and built a bovel, and made a little clearing on the edge of the lake. At that time there was no other habitation within many miles of them, and they passed several years in almost absolute solitude. They have now three farms, some hundred acres of land, and have brought up nine sons and daughters, most of whom are married, and settled on lands of their own. She gave me a horrid picture of the prevalence of drunkenness, the vice and the curse of this country.

I can give you no idea of the intense cold of this night; I was obliged to wrap my fur cloak round me before I could go to sleep. I rose ill and could eat no breakfast, in spite of all the coaxing of the good landlady; she got out her best tea, kept for her own drinking, (which tasted for all the world, like musty bay,) and buttered toast, $i$. e. fried bread steeped in melted butter, and fruit preserved in molasses-to all which I shall get used in time-I must try, at least, or " thank Heaven, fasting." We proceeded eighteen miles further, to St. Catherine's, the situation of which appeared to me very pretty even in winter, and must be beautiful in summer. I am told it is a place of importance, owing to the vicinity of the Welland Canal, which connects Lake Ontario with Lake Erie: it contains more than seven hundred inhabitants. The school here 
is rockoned the best in the district. Wo passed this morning soveral streams, which in summer flow into the lake, now all frozen up and undiatinguisha. ble, except by the wooden bridges which cross them, and the mills, now still and useless, erected along their banks. These streams have the names of Thirty Mile Creek, Forty Mile Creek, Twenty Mile Creek, and so on; but wherefore I could not discover.

From St. Catherine's we proceeded twelve miles farther, to Niagara. There I found some old English or rather Irish friends ready to welcome me with joyous affection; and surely there is not a more blessed sight than the face of an old friend in a new land!

January 26.

The town of Niagara presents the same torpid appearance which seems to prevail every where at this season; it is situated at the mouth of the river Niagara, and is a place of much business and resort when the navigation is open. The lake does not freeze here, owing to the depth of its majestic waters; neicher does the river, from the velocity of its current; yet both are blocked up by the huge frag. ments of ice which are brought duwn from Lake Erie, and which, aniting and accumulating at the mouth of the river, form a field of ice extending far into the lake. How beautiful it looked to-day, broken into vast longitudinal flakes of alternate white and azure, and sparkling in the sunshine! 
There are dock-yards bere lately erected, dry docks, iron works of some extent, and a steam-engine for hauling up vessels for repair; the chief proprietor is a good-natured and public-spirited gentleman, Captain Melville. He tells me that upwards of twenty thousand pounds have been expended on these works, and they employ constantly about fifty workmen; yet, in spite of this, and in spite of its local advantages, as a frontier town and the oldest settlement in Upper Canada, Niagara does not make progress. The population and the number of houses have remained nearly stationary for the last five years. I find the people complaining much of the want of a good school.

The land all around Niagara is particularly fine and fertile, and it has been longer cleared and cultivated than in other parts of the province. The country, they say, is most beautiful in summer, taxes are trifling, scarcely felt, and there are no poor-rates; yet ignorance, recklessness, despondency, and inebriety, seem to prevail. A-, who has been settled here for five years, and $B-$ himself a Canadian, rate the morality of the Canadian popufation frightfully low; lying and drunkenness they spoke of as nearly universal; men who come here with sober habits quickly fall into the vice of the country; and those who have the least propensity to drinking find the means of gratification comparatively cheap, and little check from public opinion.

Men learn to drink, who never drank before;

And those who always drank, now drink the more.

vor. 1 .

6 
Though I parody, I do not jest ; for in truth, if all, or even half, of what I beard to-day be true, this is a horrible state of thingo. I asked for a bookseller's shop; there is not one in the town, but plenty of taverns. There is a duty of thirty per cent. on books imported from the United States, and the expense on books imported from England adds at least one-third to their price; but there is no duty on whiskey. "If government," said B-, "were to lay a duty on whiskey, we should only have the province overrun with illicit stills, and another cource of crime and depravity added to the main one."

Sir Francis Head recommended to me, playfully, to get up a grievance, that I might have an excuse for paying him a visit. I think $I$ will represent to his Excellency the dearness of books and the cheapness of whiskey. I could not invent a worse grievance either in earuest or in jest.

The opposite shore, about a quarter of a mile off, is the State of New-York. The Americans have a fort on their side, and we also have a fort on ours. What the amount of their garrison muy be I know not, but our force consists of three privates and a corporal, with adequate arms and ammunition, i. e. rusty firelocks and damaged guns. The fortress itself I mistook for a dilapidated brewery. This is charming-it looks like peace and security, at all events. 
Jenuary 20.

Well! I have seen these cataracts of Niagara, which have thundered in my mind's ear ever sinco I can remember - which have been my "childbood's thought, my youth's desire," since first my imagination was awakened to wonder and to wish. I haro beheld them, and shall I whisper it to you !-but, 0 tell it not among the Philistines! - I wish I had not! I wish they were still a thing unbeheld-a thing to be imagined, hoped, and anticipatedsomething to live for:-the reality has displaced from my mind an allusion farmore magnificent than itself-I have no words for my utter disappointment : yet $I$ have not the presumption to suppose that all $I$ havo heard and read of Niagarn is false or exaggerated-that every expression of astonishment, enthusiasm, rapture, is affectation or hyperbole. No! it must be my own fault. Terni, and some of the Swiss cataracts leaping from their mountains, have affected me a thousand times more than all the immensity of Niagara. O I could beat myself! and now there is no help!一the first moment, the first impression is over-is lost ; though I should live a thousand years, long as Niagara itself shall roll, I can never see it again for the first time. Something is gone that cannot be restored. What has come over my soul and senses? - I am no longer Anna-I am metamorphosed-I am translated-I am an ass's head, a clod, a wooden spoon, a fat weed growing on Lethe's bank, a stock, a stone, a petrifaction-for have I not seen Niagara, the 
wonder of wouders; and felt-no words can tell what disappoiutment!

But, to take things in order : we set off for the Falls yesterday morning, with the intention of spending the day there, sleeping, and returning the next day to Niagara. The distance is fourteen miles, by a road winding along the banks of the Niagara river, and over the Queenston beights ; and beautiful must this land be in suminer, since even now it is beautiful. The flower garden, the trim shrubbery, the lawn, the meadow with its hedgerows, when frozen up and wrapt in snow, always give me the idea of something not only desolate but dead: $\mathrm{Na}$ ture is the ghost of herself, and trails a spectral pall; I always feel a kind of pity - a touch of melancholy-when at this season I have wandered among withered shrubs and buried flower-beds; but here, in the wilderness, where Nature is wholly independent of art, she does not die, nor yet mourn; she lies down to rest on the bosom of Winter, and the aged one folds her in his robe of ermine and jewels, and rocks her with his burricanes, and bushes ber to sleep. How still it was! how calm, how rast the glittering white waste and the dark purple forests! The sun shone out, and the sky was without a cloud; yet we saw fow people, and for many miles the hissing of our sloigh, as we flew along upon our dazzling path, and the tinkling of the sleigh-bells, were the only sounds we heard. When we were within four or five miles of the Falls, I atopped the sleigh from time to time to listen for the roar of the cataracts, but the state of the atmos. 
phere was not fiverable for tho tringmimion of sound, and the silence was unbroken.

Buch was the deop, nosctosons treguillity which prevailed on every sido- $>$ exquivine? pure and restal-like the robe in which all outure by slumbering around us, I could scarce telleve the this whole frontier district is not only rewuri.ative for the prevalence of vice, but of dark and drayen rate crime.

Mr. A., who is a magistrate, poiried out iv we lonely house by the way-side, whete, on a curk stormy night in the preceding winter, we tiac ousprised and arrested a gang of forgers axc cumbses; it was a fearful description. For brow :iun: $12 \cdot y$ impatience bad been tbus begui.

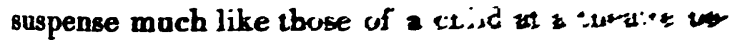

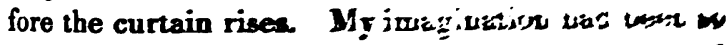
impressed by the vast beigita of tue $f_{2}$ 'ir. : Lut 1

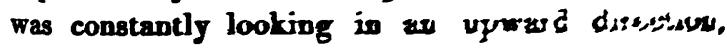
when, as we came to the brum of a $4 \mathrm{i}$, w?

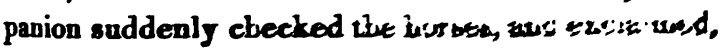
"The Falls!"

I was not, for an instant, awerte of ives is ys

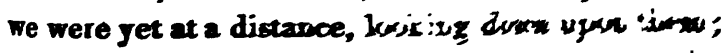
and I saw at one glance a thit sxysus;re ysahi, tiw

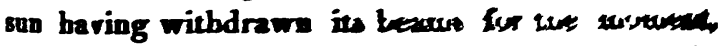

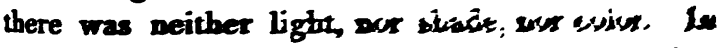
the midst were neen tbe two great coturwete, ind

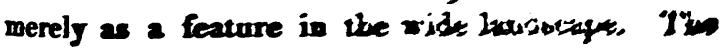
sound was by wo means orerprowerivy, and the clouds of spray, which Fawy Lutier etaied wi wawn tifully the "everdating iwcesce of tive wuess" 
now condensed ere they rose by the excessive cold, fell round the bese of the cataracts in floecy folds, just concealing that furious embrace of the waters above and the waters below. All the aesociations which in imagination I had gatbered round the scene, its appalling terrors, its soul-subduing beauty, power and beight, and velocity and immensity, were all diminished in effect, or wholly lost.

I was quite silent-my very soul sunk within me: On seeing my disappointment (written, I suppose, most legibly in my countenance) my companion began to comfort me, by telling me of all those who had been disappointed on the first view of Niagara, and had confessed it. I did confess; but I was not to be comforted. We held on our way to the Clifton hotel, at the foot of the hill; most desolate it looked with its summer verandahs and open balconies cumbered up with snow, and hung round with icicles-its forlorn, empty rooms, broken windows, and dusty dinner tables. The poor people whe kept the house in winter had gathered themselves for warmth and comfort into a little kitchen, and when we made our appearance, stared at us with a blank amazement, which showed what a rare thing was the sight of a visitor at this season.

While the horses were cared for, I went up into the highest balcony to command a better view of the cataracts ; a little Yankee boy, with a shrewd, sharp face, and twinkling black eyes, acting as my gentleman usher. As I stood gazing on the scene which soemed to enlarge upon my rision, the little 
fellow atuck his bands into his pockets, and looking up in my face, said,

"You be from the old country, I reckon ?"

"Yes."

"Out over there, beyond the sea $?$ "

"Yes."

"And did you come all that way across the sea for these bere Falls ?"

"Yes"

"My! !" Then after a long pause, and eyeing me with a most comical expression of impudence and fun, he added, "Now, do you know what them 'ere birds are, out yonder?" pointing to a number of gulls which were hovering and sporting amid the spray, rising and sinking and wheeling around, appearing to delight in playing on the verge of this "hell of waters" and almost dipping their wings into the foam. My eyes were, in truth, fixed on these fair, fearless creatures, and they had suggested already twenty fanciful similitudes, when I was roused by this question.

"Those birds ?" said I. "Why, what are they ?"

"Why, them's EAGLE!"

"Eagles?" it was impossible to help laughing.

"Yes," said the urchin sturdily; " and I guess you have none of them in the old country ?"

"Not many eagles, my boy ; but plenty of gulls!" and I gave him a pretty considerable pinch by the ear.

"Ay!" said he, laughing; "well now, you be dreadful smart-amarter than many folks that como here!". 
W'o now propared to walk to the Crescent fall, and I bound some crampons to my foet, like those they use among the $A^{1}$ ps, without which I could not for a moment have kept my footing on the frozen surface of the snow. As we approached the Table Rock, the whole scene assumed a wild and wonderful magnificence ; down came the dark-green waters, hurrying with them over the edge of the precipice enormous blocks of ice brought down from Lake Erie. On each side of the Falls, from the ledges and overhanging cliffs, were suspended huge icicles, some twenty, some thirty feet in length, thicker than the body of a man, and in color of a paly green, like the glaciers of the Alps; and all the crags below, which projected from the boiling eddying waters, were incrusted, and in a manner built round with ice, which had formed into immense crystals, like basaltic columns, such as $I$ have seen in the pictures of Staffa and the Giant's Causeway; and every tree, and leaf, and branch, fringing the rocks and ravines, were wrought in ice. On them, and on the wooden buildings erected near the Table Rock, the spray from the cataract had accumulated and formed into the most beautiful crystals and tracery work ; they looked like houses of glass, welted and moulded into regular ornamental shapes, and hung round with a rich fringe of icy points. Wherever we stond we were on unsafe ground, for the snow, when heaped up as now to the height of three or four feet, frequently slipped in masses from the bare rock, and on its surface the spray, for over falling, was converted into a sheet of ice, smooth, compact, and 
glassy, on which I could not have stood a moment without my crampons. It was very fearful, and yet I could not tear myself away, but remained on the Table Rock, even on the very edge of it, till a kind of dreamy fascination came over me; the continuous thunder, and might and morement of the lapsing waters, held all my vital spirits bound up as by a spell. Then, as at last I turned away, the descending sun broke out, and an Iris appeared below the American Fall, one extremity resting on a snow mound; and motionless there it hung in the midst of restless terrors, its beautiful but rather pale hues contrasting with the death-like colorless objects around; it reminded me of the faint ethereal smile of a dying martyr.

We wandered about for nearly four hours, and then returned to the hotel : there my good-natured escort from Toronto, Mr. Campbell, was waiting to conduct us to his house, which is finely situated on an eminence not far from the great cataract. We did not know, till we arrived there, that the young and lovely wife of our host had been confined only the day before. This event had been concealed from us, lest we should have some scruples about accepting hospitality under such circumstances; and, in truth, I did feel at first a little uncomfortable, and rather de trop; but the genuine kindness of our reception soon overcame all scruples: we were made welcome, and soon felt ourselves so ; and, for my own part, I have always sympathies ready for such occasions, and shared very honestly in the grateful joy of these kind poople. After dinner I 
went up into the room of the invalid-a little nest of warmth and comfort; and though the roar of the neighboring cataract shook the house as with a universal tremor, it did not quite overpower the soft roice of the weak but happy mother, nor even the feeble wail of the new-born babe, as I took it in my arms with a whispered blessing, and it fell asleep in my lap. Poor little thing !-it was an awful sort of lullaby, that ceaseless thunder of the mighty waters ever at hand, yet no one but myself seemed to heed, or even to hear it ; such is the force of custom, and the power of adaptation even in our most delicate organs.

To sleep at the hotel was impossible, and to intrude ourselves on the Campbells equally so. It was near midnight when we mounted our sleigh to return to the town of Niagara, and, as I remember, I did not utter a word during the whole fourteen miles. The air was still, though keen, the snow lay around, the whole earth seemed to slumber in a ghastly, calm repose; but the heavens were wide awake. There the Aurora Borealis was holding her revels, and dancing and flashing, and varying through all shapes and all hues-pale amber, rose tint, blood red-and the stars shone out with a fitful, restless brilliance; and every now and then a meteor would shoot athwart the skies, or fall to earth, and all around me was wild, and strange, and excitingmore like a fever dream than a reality.

To-day I am suffering, as might be expected, with pain and stiffness, unable to walk across the room; but the pain will pass : and on the whole I am glad 
I have made this excursion. The Falls did not make on my mind the impression I had anticipatod, perhaps for that reason, even because I had anticipated it Cnder different circumstances it might have been otherwise; but " it was sung to mo in my cradle," as the Germans say," that I should live to be disappointed-eren in the Falls of Niagara.

Toronto, February 7.

Mr. B. gave me a seat in his sleigh, and after a rapid and very pleasant journey, during which $I$ gained a geod deal of information, we reached To. ronto yesterday morning.

The road was the same as before-with one de. viation however-it was found expedient to cross Burlington Bay on the ice, about seven miles over, the lake beneath being twenty, and five-and-twenty fathoms in depth. It was ten o'clock at night, and the only light was that reflected from the snow. The beaten track, from which it is not safe to deviate, was very narrow, and a man, in the worst, if not the last stage of intoxication, noisy and brutally reckless, was driving before us in a sleigh. All this, with the novelty of the situation, the tremendous cracking of the ice at every instant, gave me a sense of apprebension just sufficient to be exciting, rather

" "So war mir's in der Wicge gesungen," is a common phrase in the north of Germany to express comething to which we are ceomingly predeatined. 
than very unpleasant, though I will confess to a feeling of relief when we were once more on the solid earth.

B. is said to be a hard, active, clever, practical man. I liked him, and thought him intelligent and good-natured : we had much talk. Leaving his servant to drive, he would jump down, stand poised upon one of the runners, and, thus gliding smoothly along, we conversed.

It is a remarkable fact, with which you are probably acquainted, that when one growth of timber is cleared from the land, another of quite a different species springs up spontaneously in its place. Thus, the oak or the beech succeeds to the pine, and the pine to the oak or maple. This is not accounted for, at least I have found no one yet who can give me a reason for it. We passed by a forest lately consumed by fire, and I asked why, in clearing the woods, they did not leave groups of the finest trees, or even single trees, here and there, to embel. lish the country? But it seems that this is impossible-for the trees thus left standing, when deprived of the shelter and society to which they have been accustomed, uniformly perish - which, for mine own poor part, I thought very natural.

A Canadian settler hates a.tree, regards it as his natural enemy, as something to be dostroyed, eradi. cated, annihilated by all and any means. The idea of useful or ornamental is seldom associated here even with the most magnificent timber trees, such as among the Druids bad been consecrated, and among the Greeks would have sheltered oracles and 
votive temples. The beautiful faith which aseigned to every tree of the forest its guardian nymph, to every leafy grove its tutelary divinity, would find no votaries here. Alas! for the Dryads and Hamadryads of Canada!

There are two principal methods of killing trees in this country, besides the quick, unfailing destruction of the axe; the first by setting fire to them, which sometimes leaves the root uninjured to rot gradually and unseen, or be grubbed up at leisure, or, moro generally, there remains a visible fragment of a charred and blackened stump, deformed and painful to look upon; the other method is slower, but even more effectual; a deep gash is cut through the bark inte the stem, quite round the bole of the tree. This prevents the circulation of the vital juices, and by degrees the treo droops and dies. This is technically called ringing timber. Is not this like the two ways in which a woman's heart may be killed in this world of ours-by passion and by sorrow? But better far the swift fiery death chan this " ringing," as they call it!

February 17.

"There is no society in Toronto," is what I hear repeated all around me-even by those who compose the only society we have. "But," you will say, " what could be expected in a nemote town, which forty years ago was an uninhabited swamp, and ¿wonty years ago only began to exist?" I really vos. $\mathrm{s}$ 
do not kuow what I expected, but I will tell you what I did not expect. I did not expect to find here in this new capital of a new country, with the boundless furest withiu half a mile of us on almost every side-concentrated as it were the worst evils of our old and most artificial social system at home, with none of its agremens, and none of its advantages. Toronto is like a fourth or fifth rate provincial town, with the pretensions of a capital city. We have bere a petty colonial oligarchy, a self-constituted aristocracy, based upon nothing real, nor eren upon any thing imaginary; and we have all the mutual jealousy and fear, and petty gossip, and mutual meddling and mean rivalship, which are common in a small society of which the members are well known to each other, a society composed, like all societies, of many heterogeneous particles ; but as these circulate within very confined limits, there is uo getting out of the way of what one most dislikes : we must necessarily bear, see, and passively endure much that annoys and disgusts any one accustomed to the indepeudence of a large and jiberal society, or the ease of continental life. It is curious enough to see how quickly a new fashion, or a new folly, is imported from the old country, and with what difficulty and delay a new idea finds its way into the heads of the people, or a new book into their hands. Yet, in the midst of all this, I cannot but see that good spirits and corrective principles are at work; that progress is making : though the march of intellect be not here in double quick 
time, as in Europe, it does not abeolutely etand stock -still.

There roigns here a hateful factious spirit in polftical matters, but for the present no public or patriotic feeling, no recognition of general or generous principles of poliey : as yot I have meet with none of these. . Canada is a colony, not a eountry ; it is not yot identified with the dearest affections and ar sociations, remembrances, and hopes of its inhabitants : it is to them an adopted, not a real mother. Their love, their pride, are not for poor Canada, but for high and happy England; but a few more generations must change all this.

We have bere Tories, Whigs, and Radicals, so called; but these words do not signify exactly what we mean by the same designations at home.

You must recollect that the first settlers in Upper Canada were those who were obliged to fly from the United States during the revolutionary war, in consequence of their attachment to the British government, and the soldiers and non-commissioned officers who had fought during the war. These were reeompensed for their losses, sufferings, and services, by grants of land in Upper Canada. Thus the very first elements out of which our social system was framed, were repugnance and contempt for the new institutions of the United States, and a dislike to the people of that country-a very natural result of foregoing causes; and thus it has happened that the slightest tinge of democratic, or even liberal principles in politics, was for a long time a sufficient imperchment of the loyalty, a stain upon the por- 
conal character, of those who held them. The Tories have therefore been hitherto the influential party ; in their hands we find the government patronage, the principal offices, the sales and grants of land, for a long series of years.

Another party, professing the same boundless loyalty to the mother country, and the same dislike for the principles and institutions of their Yankee neighbors, may be called the Whigs of Upper $\mathrm{Ca}$ nada; these look with jealousy and scorn on the power and prejudices of the Tory families, and insist on the necessity of many reforms in the colonial government. Many of these are young men of talent, and professional men, who find themselves shut out from what they regasd as their fair proportion of social consideration and influence, such as, in a small society like this, their superior education and character ought to command for them.

A nother set are the Radicals, whom I generally hear mentioned as "those scoundrels," or " those rascals," or with some epithet expressive of the utmost contempt and disgust. They are those who wish to see this country erected into a republic, like the United States. A few among them are men of talent and education, but at present they are neither influential nor formidable.

There is among all parties a general tone of complaint and discontent-a mutual distrust-a languor and supineness - the causes of which I cannot as yet understand. Even those who are enthusiastically British in heart and feeling, who sincerely believe that it is the true interest of the colony to remein 
under the control of the mother country, are as divcontented as the rest : they bitterly denounce the ignorance of the colonial officials at home, with ro gard to the true interests of the country : they ascribe the want of capital for improvement on a large scale to no mistrust in the resources of the country, but to a want of confidence in the measures of the government, and the security of property.

In order to understand something of the feelings which prevail here, you must bear in mind the distinction between the two provinces of Uppor and Lower Canada. The project of uniting them once more into one legislature, with a central metropolis, is most violently opposed by those whose personal interests and convenience would suffer materially by a change in the seat of government. I have heard some persons go so far as to declare, that if the union of the two provinces were to be established by law, it were sufficient to absolve a man from his allegiance. On the other hand, the measure has powerful advucates in both provinces." It seems, on looking over the map of this rast and magnifieent country, and reading its whole history, that the political division into five provinces, $f$ each with its independent governor and legislature, its separate correspoudence with the Colonial-office, its local laws, and local taxation, must certainly add to the amount of coloniad patronage, and perhaps ren-

- A very clever paper on this subject was published in the Quebec Mercury; Sept. 14th, 1837. .

+ Viz. Upper Cánada, Lower Canada, Nova Beotia, NewBrunswick, and Prince Edward's Island. 
der more secure the subjection of the whole to the Britioh crown ; but may it not aleo have perpetuated local distinctions and jealousies-kept alive divided

- interests, narrowed the resources, and prevented the improvement of the country on a large and general scale?

But I bad better stop here, ere I get beyond my depth. I am not one of those who opine sagely, that women have nothing to do with politics. On the contrary ; but I do seriously think, that no one, be it man or woman, ought to talk, much less write, on what they do not understand. Not but that I have my own ideas on' these matters, though we were nover able to make out, either to my own satisfaction or to yours, whether I am a Whig, or Tory, or Radical. In politics I acknowledge but two parties-those who hope and those who fear. In morals, but two parties-those who lie and those who speak truth : and all the world I divide into those who love, and those who hate. This comprehensive arrangement saves me a vast deal of trouble, . and answers all my own purposes to admiration.

Fubruary 18.

Toronto is, as a residence, worse and better than other small communities-vorse in so much as it is remote from all the best advantages of a high state of civilization, while it is infected by all its evils, all its fullies; and better, because, besides being a small place, it is a young place; and in spite of this affectation of looking back, instead of looking up, 
in medrance-it may bocomo the tbirking head al beating heart of a nation, great, wime, and

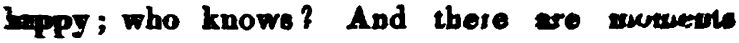
when, considered under this point of view, it sames an interest even to me; but at prowert it is in a false position, like that of a youth ypiny ussele. rity ; or rather like that of the litte buy is H'oparti'. picture, dressed in a long-flujpod laved waretorest. ruffes, and cocked-hat, crying fior bread and sutcors With the interminable foretso withis holf as isce of us-the haunt of the red mian, the wist, tise to:sts -

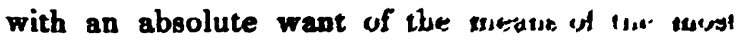
ordinary mental and moral developinusu', w. hias.

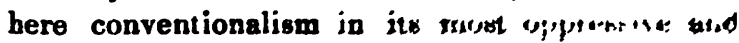
ridiculous forms. If I oluesuld wy, thet ut prososst the people here wayt cultivation, want prinis, and the means of acquiring eithes, that is satura! - is iss.

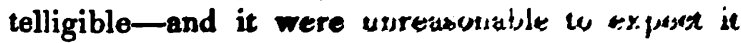
could be otherwive; bot if 1 wy they wain bousesty, you would understand one, they would wer; tho-y would imagine that I accunsed thetu of lin wo waights and cheating at cards. Bo, tur they ure cortuiuly "indifferent bonest" afure a Eastion, but wever did

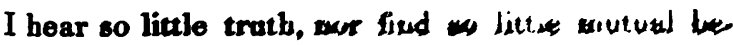
nevolence. And why is it \& L hesause in this place, as in other small provisucial urwest, they live under the principle of fear-ibey all alizid of each other, afraid wo thexuselves; and whest there is much fear, there is little kove, and truth.

I was reading this morning" of Maria d'Escecturt.

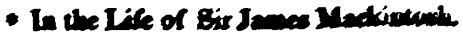


a Spanish lady, who firat brought a fow grains of wheat into the city of Lima. 'For three years she distributed the produce, giving twenty grains to one man, thirty grains to another, and so on-hence all the corn in Peru.

Is there no one who will bring a few grains of truth to Toronto?

February 21.

The monotony of this, my most monotonous existence, was fearfully broken last night. I had gone early to my room, and had just rung for my maid, when I was aware of a strange light flashing through the atmosphere-a fire was raging in the lower parts of the city. I looked out; there was the full moon, brighter than ever she shows her fair face in our dear cloudy England-bright and calm as you now behold ber in the Mediterranean, looking down upon the snowy landscape, and the icy bay glittered like a sheet of silver; and on the other side of the heavens all was terror and tumult-clouds of smoke, mingled with spires of flame, rose into the sky. Far off the garrison was beating to arms-the bells tolling; yet all around there was not a living being to be seen, and the snow-waste was still as death.

Fires are not uncommon in Toronto, where the houses are mostly wood; they have generelly an alarum once or twice a week, and six or eight houses burned in the course of the winter; but it was evident this was of more fearful extent than 
usual. Finding, on inquiry, that all the bousebold had gone off to the scene of action, my own maid excepted, I prepared to follow, for it was impossible to remain here idly gazing on the flames, and listening to the distant shouts in ignorance and suspense. The fire was in the principal street, (Kingstreet,) and five houses were burning together. I made my way through the snow-heaped, deserted streets, and into a kind of court or garden at the back of the blazing houses. There was a vast and motley pile of household stuff in the midst, and a poor woman keeping guard over it, nearly up to her knees in the snow. I stood on the top of a bedstead, leaning on her shoulder, and thus we remained till the whole row of buildings had fallen in. The Irishmen (God bless my countrymen! for in all good-all mischief-all frolic-all danger-they are sure to be the first) risked their lives most bravely; their dark figures moving to and fro amid the blazing rafters, their fine attitudes, and the recklessness with which they flung themselves into the most horrible situations, became at last too fearfully exciting. I was myself so near, and the flames were so tremendous, that one side of my face was scorched and blistered.

All this time, the poor woman on whose shoulder I was leaning, stood silent and motionless, gazing with apparent tranquillity on her burning house. I remember saying to hor with a shudder-" But this is dreadfult to stand by and look on while one's bome and property are destroyed !" And she replied quietly, "Yes, ma'am; but I dare say somo 
good will come of it. All is for the best, if one knew it; and now Jemmy's safe, I don't care for the rest." Now Jemmy was not ber son, as 1 found, but a poor little orphan, of whom she took charge.

There had been at first a scarcity of water, but a hole being hewed through the ice on the lake, the supply was soon quick and plentiful. All would have been well over, if the sudden fall of a stack of chimneys had not caused some horrible injuries. One poor boy was killed, and some others maimed - poor Mr. B. among the number. After this I returned bome rather heart-sick, and nigh to the house a sleigh glanced by at a full gallop, on which I could just perceive, in the moonlight, the extended form of a man with his hands clenched over his head-as in agony, or lifeless.

Talking this morning of the incidents of last uight, several people have attempted to comfort themselves and me too with the assurance, that whatever might be the private loss or suffering, a fire was always a public benefit in Toronto-a good brick house was sure to arise in the place of a wooden one. It may be so-brick houses are better certainly than wooden ones-safer too; but as a general argument, I never can bear to think that any public benefit can be based on individual suffering : I hate the doctrine, and am not convinced by the logic. In these days of political economy, it is too much a fashion to consider buman beings only in masses. Wondrous, and vast, and all-importanta s is this wide frame of human society, with 
If is component elements variously blended-all iz agnifsecat destinies-is it more important in :be sigite of God, more fearful, more sublime to costemplate, than that mysterious world of pow. ex, and affections, and aspirations, which we call ite haman soul?

In what regards government and politics, do wo not find the interest of the many sacrificed to the few; while, in all that regards society, the morals and the happiness of individuals are sacrificed to the many? and both are wrong. I never can bring myself to admire a social system, in which tho ho. nor, rights, or happiness of any individual, though the meanest, is made to yield to a supposed futuro or general good. It is a wicked calculation, and it will be found as inexpedient as it is wicked.

We women have especial reason to exclaim against this principle. We are told openly by moralists and politicians, that it is for the general good of society, nay, an absolute necessity, that one-fifth part of our sex should be condemned an the legitimate prey of the other, predoomed to die in reprobation, in the streets, in bospitals, that the virtue of the rest may be preserved, and the pride and the passions of men both gratified. But I have a bitter pleasure in thinking that this most base, most cruel conventional law is avenged upon those who made and uphold it; that bere the sacrifice of a certain number of one sex to the permitted license of the other is no general good, but a general curse-a very uker in the bosom of society.

The subject is a bateful one-more hetoful is it 
to hear it sometimes alluded to with sneering levity, and sometimes waved aside with a fastidious or arrogant prudery. Unloss we women take some courage to look upon the evil, and find some belp, some remedy within ourselves, I know not where it is to come from.

F. told me yesterday a story which I must try to note down for you, if $I$ can find fit words in which to relate it. It is another proof that the realities of life transcend all fiction. I have known-have seen with these mine own eyes, more of tragedy and romance than I would dare to reveal-and who has not?

F. told me, that when he was serving in the army in the Lower Province, a young officer, one of his own friends, (mentioning his name,) seduced from her parents a very pretty girl, about fifteen or sixtoen. F. knew something of her family, which was respectable, and tried to save her, but in vain. After some months, the officer $\mathrm{S}$. became tired of his victim, and made her over to a brother officer. F. again interfered, and the poot girl did for a time return to her parents, who gladly and gratefully received her; but she was spoiled for her home, and her home was spoiled for her; the sources of innocent pleasure were poisoned, and why should we wonder and exclaim, if a woman who has once known the flatteries and caresses of love, find it hand-most hard-to resign herself to days and nights, solitary, toilsome, joyless, unendeared? After a while, the colonel of the regiment found means to allure ber again from her home; he be- 
came strongly attached to her, she was faithful and dercted to him, and be took her with him to England.

Years had passed away, when S., who had left the army, also returned to England. While he wes roaming about London, amusing bimself as young men are wont todo after a long absence from the contral mart of pleasure and dissipation, he betook himself ene evening, after a tavern dinner, to some house of infamous resort, and one of the wretched women of the establishment was sent to him as a companion. As she entered the room, $\mathbf{S}$. ctarted from the sofa to encounter in the impudent, degreded, haggard, tawdry thing before him, the poor child who had beer his victim in Canada; but long yours of vice and misery bed not yet utterly hardened her. They steod face to face for a few seconds, and looked in sileace upon each other, (and whu can tell whese in those few seconds may have passed through the minds of each?) and then the miserablo girl fen senseless on the floor.

He raised ber up, and, in the remorse and agony of the moment, offered her all he had in the world;-poor, poor compensation! He urged her return to Canada:-be would pay all her expensesplace her beyond the reach of want-but it was all in vain.

After the first burst of feeling was over, the wretched girl shook him from ber with sullen scorn and despair, and not only refused to return to the bome she had disgraced, but even to accept from him any thing whatever-and thus she left him. Ho it was-limself-who described the scene to F.

vox. 1 . 
"Poor fellow !" said F., in conclusion, " he did not rocorer it for a long time-he felt it rery much !"

Poor follow! - and yet he was to be pitied; be did not make the oystem under which be was oducated.

" What became of Captain S. 2" I asked.

“ $O$, he married well; he is now a very respectaHo and excellent man-father of a family."

"He has children, then ?"

"Yos; several."

"Daughters ?"

"Yos."

"No doubt," thought I, " he will take care of them."

And yet one word more before I throw down my pen. I have wandered far from the fire in King. street-but no matter.

How often we bear repeated that most false and valgar commonplace, that the rakes and libertines of the other sex are sure to find favor with womenoren the most virtuous women! This has been repeated over and over again by wits and playwrights till foolish women take the thing for granted, and foolish men aim at such a reputation as a means of pleasing us. $O$ the folly in them-the insult to us ! No man ever pleased a woman because he was a libertine. What virtuous woman has the least idea of what a libertine really is ? What fair, innocent girl, who hears a very agreeable and perfectly wellbred man stigmatized as such, images, the thing to herself? Does she know what it means? Can she follow such a man into bis daily life, his bought 


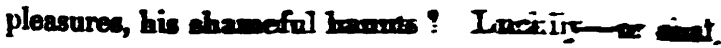

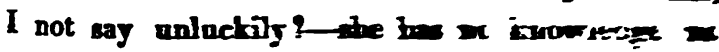
conception even, of all tivic í tive rmex laid open to her, how she wovic sinsic frow

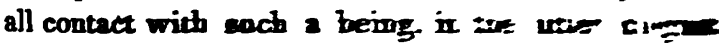

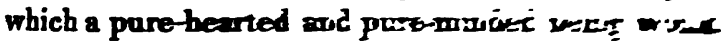

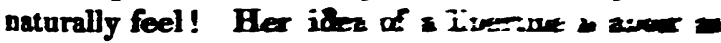

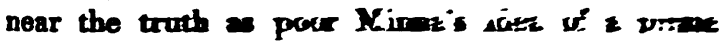
And so that which is the resure of 410

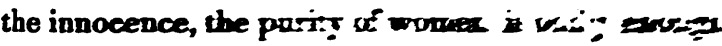
converted into reproad tgainc me.

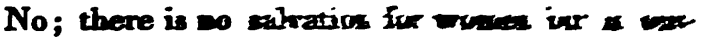

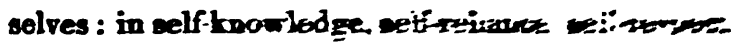

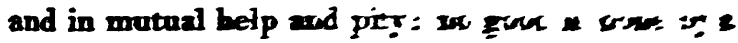

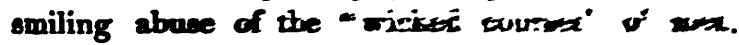

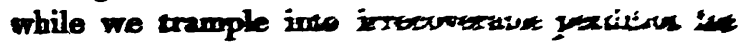
weak and erring of orr ow wex.

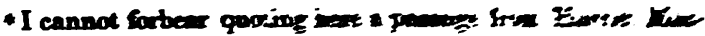

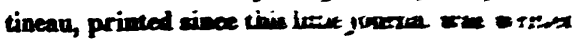

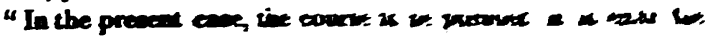

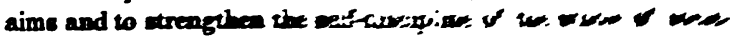

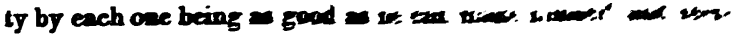

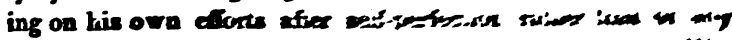

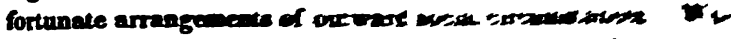

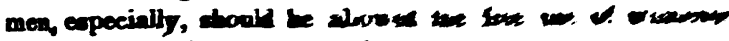

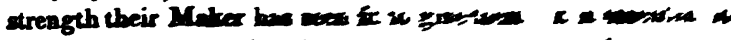

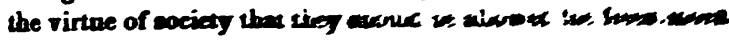

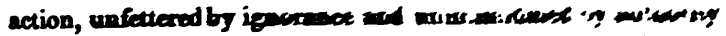

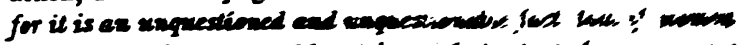

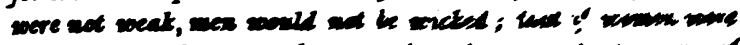

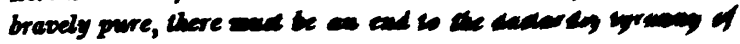

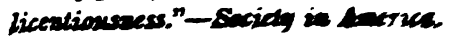


February 24.

"Co qui est moins que moi, m'éteint et m'assomme: ce qui est $a$ côté de moi m'ennuie et me fatigue : il n'y a que ce quilest au-dessus de moi qui me sout:enne et m'arrache à moimemo." This is truehow true, I feel, and far more prettily said than I could say it; and thus it is that during these last fow days of illuess and solitary confinement, I took refuge in another and a higher world, and bring you my ideas thereupon.

I have been reading over again the Iphigenia, the Tasso, and the Egmont of Goèthe.

Iphigenia is all repose; Tasso all emotion; Egmont all action and passion. Iphigenia rests upon the grace and grandeur of form-it is statuesque throughout. Tasso is the strife between the poetic and prosaic nature. Egmont is the working of the real; all here is palpable, practical-even love itself.

I laid down the Tasso with a depth of emotion which I bave never felt but after reading Hamlet, to which alone I could compare it; but this is a tragedy profound and complete in effect, without the intervention of any evil principle, without a dagger, without a death, without a tyrant, without a traitor! The truth of Eeonora d'Este's character struck me forcibly; it is true to itself, as a character-true to all we know of her history. The shadow which a a hidden love has thrown orer the atherwise transparent and crystalline simplicity of her mibd is very charming - more charming from the contrast with

- Mademoiaolle de l'Eepinasse. 
her friend Leonore Sanvitale, who roecneiles ber self to the project of removing Taseo with exquirite feminine subtlety and sentimental cunning.

Why do you not finish your tranalation of the Egmont? who will ever do it as you case? What doep wisdom, what knowledge of human nature in every scene! And what can be finer than the two female portraits-the imperial, imperious Margaret of Austria, and the plebeian girl, Clärchen? The character of Clărchen grows upon me as I study it Is she not really a Flemish Juliet, in her fond impatience, her wilfulness, and the energy of resolve arising out of the strength of passion? And her tenderness for her poor discarded lover, Brakenberg, whom she cannot love and cannot hate, is all so womanly naturel !

Iphigenia is an heroic tragedy-Taseo, a poetical tragedy; Egmont, an historical tragedy-Clavigo is what the Germans call a birgerliche, or domestic tragedy (tragédie bourgeoise.) I did not read this play as I read the Tasso, borne aloft into the ideal, floating on the wings of enthusiasm between the earth and stars; but I laid it down with a terrible and profound pain-yes, pain! for it was worse and deeper than mere emotion. Yet it is difficult to speak of Clavigo as a work of art. The matter-offact simplicity of the plut, the every-day nature of the characters, the prosaic sentiments, the doep homely pathos of the situations, are almost too real $\rightarrow$ they are brought home to our own bosoms, our own experienco - they are just what, in feeling 
most, we can least dare to express, The scene beiwoen Carlos and Clavigo, in which Carlos disouades his friend from marrying the woman to whom he was engaged, is absolutely wonderful. If Clevigo yielded to any mere persuasion or commonplace arguments, he would be a despicable wretchwe should feel no interest about bim, and it would sloo belie the intellect with which he is endowed. It is to that intellect, Carlos addresses himself. His arguments, under ove point of view - that of common sense-are unanswerable. His reasoning, opringing from conviction, is reason itself. What can be more practically wise than his calculationsmore undeniably true than his assertions? His shetoric, dictated as it is by real friendship, and full of fre and animation, is even more overwhelming from its sincerity than its eloquence; and his sarcartic observations on poor Mario Beaumarchais, on hor want of personal attractions, her ill-health, ber foreign manners; on the effect she will produce on cociety as his wife, and the clog she must prove to his freedom and ambitious career, are all so well cimed, so well meant, so well founded, that far from hating Carlos and despising Clavigo, we are impressed with a terror, a sympathy, a sort of fearful fascination. Every one who reads this play must acknowledge, and with an inward shuddering, that it is possible he might have yielded to this conventional common sense, this worldly logic, even for want of arguments to disprove it. The only things left out in the admirable reasonings and calculations of Carlos, are nature and conscience, to which, in 
their combination, the world have agreed to give the name of Romance. But never yot were the feelings and instincts of our nature violated with impunity; never yet was the voice of conscienoe silenced without retribution. In the tragedy, the catastrophe is immediate and terrible; in real life it might come in some other shape, or it might come later, but it would come-of thal there is no doubt.

February 25.

The accusation which has been frequently made against Goêthe, that notwithstanding his passionate admiration for women, he bas throughout his works wilfully and systematically depreciated womanhood, is not just, in my opinion. No doubt he is not so universal as Shakspeare, nor so ideal as Schiller; but though he might have taken a more elevated and a more enlarged view of the sex, his portraits of individual women are true as truth itself. His idea of women generally was like that entertained by Lord Byron, rather oriental and sultanish; he is a little of the bashaw persuasion. "Goethe," said a friend of mine who knew him intimately, "had no notion of heroic women," (Heldenfrauen,) " in poetry, he thought them unnatural, in history, false. For such delineations as Schiller's Joan of Arc, and Stauffacher's wife (in Wilhelm Telf) he had neither faith nor sympathy."

His only heroic and ideal creation is the Iphigenia, and she is as perfect and as pure as a piece of Greek sculpture. I think it a proof that if he did 
not understand or like the actire heroism of Amazonian ladies, he had a very sublime idea of the pacoive horoism of female nature. The basis of the charecter is truth. The drama is the very triumph of unsullied, unflinching truth. It has been said, that Goesthe intended this character as a portrait of the Grand Duchess Louise, of Weimar. The intention of the poet remains doubtful; but it should seem that from the first moment the resemblance wa generally admitted : and what a glorious compliment to the Duchess was this acknowledgment! It was through this true-heartedness, this immutable integrity in word and deed, and through no shining qualities of mind, or blandishments of manner, that she prevailed over the angry passions, and commanded the respect of Napoleon, a man who openly contemned women, but whose instructions to his ambassadors and ministers always ended with "Soignez les femmes," a comment of deep import on our false position and fearful power.

February 27.

I have had a visit this morning from a man I must introduce to you more particularly. My friend, Col. F., would have pleased me any where, but here he is really invaluable.

Do you remember that lyric of Wordsworth, "The Reverie of Poor Susan," in which he de. scribes the emotions of a poor servant-girl from the 
country, whose steps are arrested in Cheapsite by the song of a caged bird ?

'Tis a note of enchantmest-what ais ber? she weet

$A$ mountain ascending, a vision of rnos;

And a single small cotiagre, a nect ink a doves,

The one only dwelling on carth thas she lores:

She looks, and her heart is is bearen!

And how near are human bearts allied in all atural instincts and sympathies, and what an unfailing, universal fount of poetry are these even in their homeliest forms! F. told me to-day, that once, as he was turning down a bye street in this little town, he heard somewhere near bim the song of the lark. (Now, you must observe, there are no larks in Canada but those which are brought from the old country.) F. shall speak in his own words: "So, ma'am, when I heard the roice of the bird in the air, I looked, by the natural instinet, up to the heavens, though I knew it could not be there, and then on this side, and then on that, and sure enough at last I saw the little creature perched on its sod of turf in a little cage, and there it kept trilling and warbling away, and there I stood stock still-lietening with my heart. Well, I don't know what it was at all that came over me, but every thing seemed to change before my eyes, and it was in poor Ireland I was again, and my home all about me, and I was again a wild slip of a boy, lying on my back on the hill-side above my mother's cabin, and watching, as I used to do, tho lark singing and soaring 
oror my hoad, and I atraining my eye to follow her till she melted into the blue aky-and there, ma'am -would you believe it ? I stood like an old fool liatening to the bird's song, lost, as in a dream, and chore I think I could have stood till this day." And the eyes of the rough soldier filled with tears, even while be laughed at himself, as perfectly unconscious that he was talking poetry, as Mons. Jourdain could be that be was talking prose.

Colonel F. is a soldier of fortune-which pbrase means, in lis case at least, that he owes nothing whatever to fortune, but every thing to his own good heart, his own good sense, and his own good sword. He was the son, and glories in it, of an Irish cotter, on the estate of the Knight of Glyn. At the age of fifteen he shouldered a musket, and joined a regimont which was ordered to Holland at the time the Duke of York was opposed to Dumourier. His only reading up to this time had been "The Seren Champions of Christendom," and "The Seven Wise Masters." With his head full of these examples of chivalry, be marched to his firat battle-field, vowing to himself, that if there were a dragon to be fought, or a giant to be defied, he would be their man!-at all events, he would enact some valorous exploit, some doughty deed of arms, which should astonish the world and dub him captain on the spot. He then described with great humor and foeling his utter astonishment and mor tification on finding the mechanical slaughter of a modern field of battle so widely different from the picture in his fancy;- when he found himself one 
of 2 mass in which the individual beart and arm, however generous, however strong, went for nothing -foreed to stand still, to fire only by the word of command-the chill it sent to his heart, and his emotions when be saw the comrade at his side fall a quirering corse at his foet-all this he described with a graphic liveliness and simplicity which was rery amusing. He was afterwards taken prisoner, and at the time he was so overcome by the idea of the indignity he had incurred by being captured and stripped, and of the affliction and dishonor that would fall on his mother, that be was tempted to commit suicide in the old Roman fashion; but on seeing a lieutenant of his own regiment brought in prisoner, he thought better of it; a dishonor which the lieutenant endured with philosophy, might, be thought, be borne by a subaltern, for by this time, at the age of eighteen, he was already sergeant.

He was soon afterwards exchanged, and ordered out to Canada with his regiment, the Forty-ninth. He obtained his commission as lieutenant in the same regiment by mere dint of bravery and talent; but as his pay was not sufficient to enable bim to live like his brother officers and purchase his accoutrements, the promotion he had earned by his good conduct became, for a long time, a source of embarrassment. During the last American war he performed a most brilliant exploit, for which he receired his captain's commission on the field: Immediately after receiving it, he astonished his commander by asking leave of absence, although another battle was expected in a few days. The request 
was, in truth, so extraordinary that General Sheaffo besitated, and at last refused. F. said, that if his request was granted, be would be again at headquarters within three days; if refused, be would go without leave. "For," said he, "I was desperate, and the trutb was, ma'am, there was a little girl that I loved, and I knew that if I could but marry her before I was killed, and I a captain, she would have the pension of a captain's widow. It was all I could leave her, and it would have been some comfort to me, though not to her, poor soul !"

Leave of absence was granted; F. mounted his horse, rode a bundred and fifty miles in an exceedingly short time, married his little girl, and returned the day following to his duties, and to fight another battle, in which, however, he was not killed, but has lived to be the father of a fine family of four brave sons and one gentle daughter.

The men who have most interested me through life were all self-educated, and what are called originals. This dear, good F. is originalissimo. Some time ago he amused me, and gave me at the same time a most vivid idea of the minor horrors and irremediable mischiefs of war, by a description of his being quartered in a church in Flanders. The soldiers, on taking possession of their lodging, began by breaking open the poor-boxes and ransacking the sacristie. They then broke up the chairs and benches for fires to cook their rations, and these not sufficing, the wooden saints and carved altars were soon torn down. Finding themselves incommoded by the smoke, some of the soldiers climbed up by 
the projecting ornaments and smashed through the windows of rich stained glass to admit the air and let out the smoke. The next morning at sunrise they left this sanctuary of religion and art a foul dofaced ruin. A century could not make good again the pollution and spoliation of those fow hours.

"You must not be too hard on us poor soldiers," added F., as if answering to a look, for I did not comment eloud. "I had a sort of instinctive perception of the mischief we were doing, but I was certainly the only one; they knew no better, and the precarious life of a soldier gives him the babit of sacrificing every thing to the present moment and a certain callousness to the suffering and destruotion which, besides that it ministers to the immediate want, is out of sight and forgotten the next instant. Why I was not quite so insensible as the rest, I carnot tell, unless it was through the goodness of God. When I was a boy, my first feeling, next to my love for my mother, was gratitude to God for having made me and called me into being out of nothing. My first thought was what I could do to please him. Now, is spite of all the priest might say, I coukd not perceive that fasting and praying would to fim any good, so I looked about in the fulness of $\mathrm{my}$ heart to see what I could do-and I' fancied there was a voice which whispered continually, 'Do good to your neighbor, do good to your neighbor !'"

With so much overflowing benevolence and fearless energy of character, and all the eccentricity, and sensibility, and poetry, and headlong courage of his country, you cannot wonder that this brave rol. 1. 
and worthy man interests mo; upluckily, I can see him seldom, his life being one of almost unremirting toil.

March 1.

In the different branches of art, each artist thinks his own the highest, and is filled with the idea of all its value and all its capabilities which be underatands best and has most largely studied and developed. "But," says Dr. Cbalmers, "we must take the testimony of each man to the worth of that which be does know, and reject the testimony of each to the comparative worthlessness of that which he does not know."

For it is not, generally speaking, that he overrates his own particular walk of art from over-enthusiasm, (no art, when considered separately, as a means of human delight and improvement, can be overrated,) but such a one-sided artist underrates from ignorance the walks of others which diverge from his own.

Of all artists, musicians are most exclusive in devotion to their own art, and in the want of sympathy, if not absolute contempt, for other arts. A painter has more sympathies with a musician, than a musician with a painter. Vernet used to bring his easel into Pergolesi's room, to paint beside his harpsicord, and used to say that he owed some of his finest skies to the inspired harmonies of his friend. 
Pergolesi never felt, perhaps, any harmonies but those of his own delicious art.

"Aspasia, be who loves not music is a beast of one species, and he who overloves it, is a beast of another, whose brain is smaller than a nightingale's, and his heart than that of a lizard!" I refer you for the rest to a striking passage in Lasdor's "Perides and Aspasia," containing a most severe philippic, not only against the professors, but the profecsion of music, and which concludes very aptly. "Panenus said this : let us never believe a word of it!" It is too true that some excellent musicians have been ignorant, and sensual, and dissipated, but there are sufficient exceptions to the sweeping censure of Panenus to show that "imprudence, intemperance, and gluttony," do not always, or necessarily, "open their channels into the sacred stream of music." Musicians are not selfish, careless, sensual, ignorant,-because they are musicians, but because, from a defective education, they are nothing else. The German musicians are generally more moral and more intellectual men than English or Italian musicians, and hence their music has taken a higher flight, is more intellectual than the music of otber countries. Music as an art has not degraded tbem, but they have elevated music.

It is impeaching the goodness of the beneficent Creator to deem that moral evil can be inseparably connected with any of the fine arts-least of all with music-the soul of the physical, as love is of the moral, universe.

The most accomplished and intellectual musician 
I over mot with is Felix Mendolsohn. I do not recollect if it were himself or some one else who told mo of a lotter which Carl von Weber had addressed to him, warning him that he never could attain the highest honors in his profession without cultivating the virtues asd the decencies of life. "A great artiot," said Weber, "ought to be a good man."

While I am " $i$ ' the vein," I must give you a few more musical reminiscences before my fingers are quite frozen.

I bed once some conversation with Thalberg and Felix Mendeleobn, on the unmeaning names which musicians often give to their works, as Concerto in F, Concerto in B b, First Symphony, Second Symphony, \&ce. Mendelsobn said, that although in almost every case the composer might have a leading idea, it would be often difficult, or even impossible, to give any title sufficiently comprehensive to convey the same ides or feeling to the mind of the bearer.

But music, except to musicians, can only give ideas, or rather raise images, by association; it can give the pleasure which the just sccordance of musical sourds must give to sensitive ears, but the ascociated ideas or images, if any, must be quite accidental. Haydn, we are told, when he sat down to compose, used first to invent a story in his own fancy-a regular suocession of imaginary incidents and foelings-to which he framed ar suited the successive morements (motivi) of his coneorto. Would it not have been an advantage if Haydn could have giren to his composition such a title as 
would have pitched the imagination of the listener at once upon the same key? Mendelsohn himself has "done this in the pieces which he has entitled "Overture to Melusina," "Orerture to the Hebrides," “Meeres Stille und Glückliche Fahrt, "The Brook," and others-which is better surely than Sonata No. 1, Sonata No. 2. Take the Melusina, for example; Is there not in the sentiment of the music, all the sentiment of the beautiful old fairy tale ?-first, in the flowing, intermingling harmony, we have the soft elemental delicacy of the water nymph ; then, the gushing of fountains, the undulating waves; then the martial prowess of the knightly lover, and the splendor of chivalry prevailing over the softer and more ethereal nature; and then, at last, the dissolution of the charm; the ebbing, fainting, and failifig away into silence of the beautiful water spirit. You will say it might answer just as well for Ondine; but this signifies little, provided we have our fancy pitched to certain poetical associations pre-existing in the composer's mind. Thus, not only poems, but pictures and statues, might be set to music. I suggested to Thalberg as a subject the Aurora of Guido. It should begin with a slow, subdued, and solemn movement, to express the slumbrous softness of that dewy hour which precedes the coming of the day, and which in the picture broods over the distant landscape, still wrapt in darkness and sleep; then the stealing upwards of the gradual dawn; the brightening, the quickening of all life; the awakening of the birds, the barst of the sunlight, the rushing of the steeds 
of Hyperion through the aky, the aerial dance of the Hourn, and the whole concluding with a magnificent choral song of triumph and rejoicing sent up from universal nature.

And then in the same spirit-no, in his own grander spirit-I would bave Mendelsohn improviser the Laocoon. There would be the pomp and procession of the sacrifice on the sea-shore; the flowing in of the waves; the two serpents which come gliding on their foamy crests, wreathing, and rearing, and undulating; the horror, the lamentation, the clash of confusion, the death struggle, and, after a deep pause, the wail of lamentation, the funereal march; the whole closing with a hymn to Apollo. Can you not just imagine such a piece of music, and composed by Mendelsohn? and can you wot fancy the possibility of setting to music in the ame manner, Raffaelle's Cupi and Psyche, or his Galatea, or the group of the Niobe? 'Niobe would be a magnificent subject either for a concerto, or for a kind of mythalogical oratorio.

March 2.

Turning over Boswell to-day, I eame upon this passage : Johnson says, "I do not commend a society where there is an agreement that what would not otberwise be fair shall be fair; but I maintain that an individual of any society who practises what is allowed, is not dishonest."

What say you to this reasoning of our great mor 


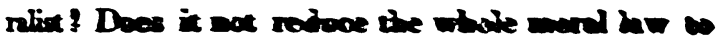
something merely cawrenticas?

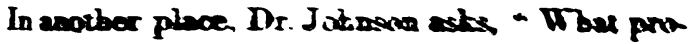

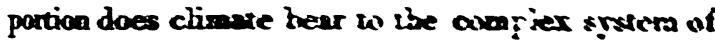
buman life?" I shirer wïie I answer. "I pind deal, my dear Doctor, to socere indiriciusis end ret more to whole races of men."

He says afterwards, - I deai more in M.ticens than in facts." And so do I, it seems.

He talks of " men being heidi durn in conrersation by the presence of women"-hrial si', rather, where moral feeling is concerned; and if held down where intellect and social interests are concerned, then 80 much the worse for such a state of society.

Johnson knew absolutely nothing about women; witness that one assertion, among others more insulting, that it is matter of indifference to a woman whether her husband be faithful or nut. Ho says, in another place, "If we men require more perfection from women than from ourselves, it is duing them honor."

Indeed! If, in exacting from us more perfoction, you do not allow us the higher and nublor nature, you do us not honor but gross injustice; and if you do allow us the higher nature, and yet regard us as sabject and inferior, then the injustice is the greater, There, Doctor, is a dilemma for you.

Of all our modern authors, Coleridge best under: stood the essential nature of women, and has said the truest and most beautiful things of our vex generally; and of all our modern authors, Hazlite was 
mont remarkable for his uttor ignorance of women, generally and individually.

Charles Lamb, of all the men I ever talked to, had the most kindly, the most compassionate, the most reverential feelings towards woman; but be did not, like Coleridge, set forth these feelings with elaborate eloquence-they came gushing out of his heart and stammering from his tongue-clothed sometimes in the quaintest disguise of ironical abuse, and sometimes in words which made the tears spring to one's eyes. He seemed to understand us not as a poet, nor yet as a man of the world; but by the unerring instinct of the most loving and benevolent of hearts.

When Coleridge said antithetically, "that it was the beauty of a woman's character to be characterless," I suppose it is as if he had said, "It is the beauty of the diamond to be colorless ;" for he instances Ophelia and Desdemona; and though they are colorless in their pure, transparent simplicity, they are as far as possible from characterless, for in the very quality of being colorless consists the character.

Speaking of Coleridge reminds me that it was from Ludwig Tieck I first learned the death of this wonderful man ; and as I, too, had- " sat at the feet of Gamaliel and heard his words," the news struck me with a solemn sorrow. I remember that Tieck. in announcing the death of Coleridge, said, in his impressive manner, "A great spirit has passed from the world, and the world knew him not." 
There are two ladies in Toromto who bare conservatories, a proof of adrancing weakb, and civilization, and taste, which you will greatly adwire. One of them had the kindness to sead we a bouquet of hot-house flowers while I was ill this hat time; and a gift of fifty times the value could nut have excited the same pleasure and gratitude. I spread the flowers out on my bed, and inbaled their fre grance with emotions I dare bardly confew-erea to you. I had not aeen a flower simee I left England.

Yesterday, (March 1th,) our provincial parliamene was prorogued by the governor in state, and 1 had the honor of assisting, as the French say, on that important occasion.

Now you would not ask me, nor do I feel inclined, to encumber my little note-book (comeecrated to far different purposes, far different themes) with information to be obtained in every book of travele and statistics; but it is just possible that you may know as little of our political constitution and forms of proceeding as I did before my arrival in $U_{p p e r}$ Canada, and I wish to make the scene of yesterday as intelligible and as intereating to you as I can, so I will give you, in as few words as possible, a sketch of our state machinery.

I have mentioned to you (I believe) that the division of the province of Quebec into Upper and Lower Canada took place in 1791 ; at that time a 
chartered constitution and a separate executive and legislative government were conferred on each province : a measure well intended, doubtless, but of which the wisdom was more than doubtful, when we consider the results.

Our constitution of Upper Canada seems, at first view, that of the mother country in miniature, and identical with it. For instance, we have, as the bead of our executive, a governor, subject, in his military capacity, to the governor-in-chief of Lower Canada, but in all other respects dependent only on the government at home, assisted by au executive coun. cil appointed by himself; and we have a legislature composed of a legislative council, nominated by the government, and a house of assembly delegated by the people. These different branches seem to represent, not unfitly, the sovereign, the cabinet of ministers, the House of Lords, and the House of Commons, in England.

But there are some important distinctions which tend to secure the dependence of the provincial legislature on the executive government at home; for I do not know that our parliament has hitherto legislated for the colonies.

When Sir Francis Head arrived here the executive council consisted of five; he added three to the number, who were noted Reformers. About three weeks afterwards this executive council addressed to the governor a document, in which they assumed as their right precisely the same powers and responsibilities as those of the cabinet ministers at home, alleging, that although nominated by the governor, 
they hold themselnes responsible to the will of the people.

To which docamest Sir Frabcis rep!lied to this effect-" that though the conssitution of the coiong resembled, it was not to be considered as ideatical with, the constization of the muber ccuntry :- that if the lieutenant-goremor stood in place of the sorereign-if, like the sorereign. be cosid do no strong, then it would be evident that a ministry, an executive conseil, or some oxber body of mea, should be appointed, who might be responsible to the country for their conduct. But this was not the case. The lieutenant-gorernor was delegated by the king, not as the representative, but as the responsible minister of the sorereign, sulject to impeachment for neglecting the interests of the people, and liable to immediate recall ; and that, under such circamstances, to render the lieutenant-goremor responsible for the acts of an executive council, which was responsible only to the people, was a manifest injustice, as well as an anomaly."

All which seems to me a very clear case as thus stated. The governor also denied not only any right or power of his own to alter one letter or iota of the constitution, but all power in the united legislature of Upper Canada to alter or improve the political constitution of the country, as by law established, this power resting only with the executive in England. From all which it appears, as far as I can understand, that the government of this province is not derived from the people who inhabit it, nor responsible to them nor their delegates. 
Immediately on receiving this answer, the oix councillors who bad presented the document or re. monstrance above-mentioned, reaigned their seats in the council, and Sir Francis immediately appointod four others. The president of the executive council-that is, the Premicr of our cabinet of $\mathrm{mi}$. nistere-is Mr. Sullivan.

The legislative council varies in number : at prewent there are, I believe, thirty members. Of these, twenty-one are Scotch and Canadians, and nine English, lrish, and Americans. They represent the aristocracy of the country, but differ from the House of Lords, in not being herereditary; they ure nominated for life by the governor. The speaker is the Chief Justice Robiuson, a Tory in politics, and a very able and accomplished man.

The House of Assembly consists of the delegates of the people, the number incteasing with the population. As soon as the number of inhabitants in a town or country amounts to a certain number fixed by law, they have the right of choosing one or two representatives in parliament. The House of Assembly consisted, in 1831, of about forty members. At present there are twenty-two counties which send each two members to parliament; three caunties which send only one member; and the four ridings of York, and the four ridings of Lincoln, each one member; and seven towns each one member: in all sixty-two members. Of these; forty-four are Conservative members, and eighteen are Reformers. - In the former House of Assembly, dissolved by Sir Francis Head in 1836, the majority were Radicals, 
or opposed to the British supremacy. The bert speakers on the Conservative side are, Hagerman, the Solicitor-general," a Tory in politics, a man of great ability and good nature, but somewhat coarse and overbearing in character and manner; Draper, the member for Toronto, $t$ a clever active-minded man, and a fluent speaker; $M \cdot N a b, \ddagger$ the member for Wentworth, also an able and influential man of large property ; and Mr. Prince, member for Sandwich, a gentleman educated at the English bar, and of very superior attainments, liberal, though not revolutionary, in principle. On the opposition side, the cleverest man and most eloquent speaker is Dr. Rolph.

The members are paid for their attendance during the session at the rate of ten shillings a-day.

This slight sketch will give you some general idea of the political constitution and the state of parties in Upper Canada.

The prorogation took place yesterday at three o'clock; when we arrived in front of the government offices the scene was very striking. The snow-expanse was all around, and between the shore of the frozen bay and the line of building, the space we filled by sleighs of all shapes and sizes, the horses curveting and kicking up the snow, and a crowd of some hundred people in all manner of strange defences against the piercing frost, intermingled with

- Now Attorney-general.

+ Now Solicitor-general.

$\$$ Afterwards Speaker of the House of Assembly. vol. 1. 
military costumes, and a few Indians lounging by in their blanket-coats and war-plumes.

The hall of the legislative council is a subject of great pride to the Canadians. It is certainly a spacious and lofty room, with a splendid throne and the usual superfluity of gilding and varnish; yet the interior decorations, (the admiration of the people bere,) are in the vilest possible taste-which critical observation I make in no offensive spirit; any thing which is attempted bere, beyond the putting together of a log-house, is praiseworthy. We must have time-time! " $E$ coll' Tempo, tutto !" On the right of the throne sat Chief Justice Robinson; be has a fine bead and acute features, and the most pleasing, insinuating voice $I$ ever heard. The judges and law officers of the crown sat at a table in front, and the other members of the legislative council were ranged on each side. My proper place was on the right, among the wives of the officials, the aristocracy of Toronto. . The toilettes around me were gay and pretty, in the fashion of two or three years ago, and all the ladies showed a disposition to be polite and amiable; but I was too much a stranger to join in the conversation, and there were none near me to give me any necessary expla:tion, or to point out any remarkable or distinguished persons, if there were such. Among the spectators opposite I remarked a man with a very extraordir nary bead and countenance, and I was told that be was a disciple of Edward Irving, and a preacher of the "Unknown Tongues," and that several persuns 
in Toronto, even members of the council, were converts to these wild doctrines.

The governor, as he alighted, was enthusiastically cheered by the populace-a circumstance rather unusual of late, and which caused a good deal of excitement and exultation around me. In a moment afterwards he entered and took his seat on the throne.

As an official representative, Sir Francis has not the advantage of the height, fine person, and military bearing of Sir John Colborne. He is a little man, with a neat, active figure, a small but intelligent head, grave and rather acute features; his bright blue eye is shrewd and quick, with an expression of mingled humor and benevolence, and his whole deportment in the highest degree unaffected and pleasing.

The members of the House of Assembly being summoned, appeared below the bar, and the governor read his speech over with very distinct utterance and much quiet self-possession. He recapitulated the most important enactments of the session, thanked the gentlemen of the House of Assembly for the promptitude with which they had relieved the king's government from the embarrassment caused by the supplies having been withheld by the late House of Assembly, and ended by congratulating both Houses on the harmony, confidence, and tranquillity which prevailed generally throughout the province.

The titles of the various bills passed during the cession were then read; they amounted to one hus 
dred and forty-seven; the reading occupied about an bour and a quarter. Among them were a few which especially fixed my attention.

For instance, there was an act for making the remedy in cases of seduction more effectual, and for the provision of children born out of wedlock by the supposed fathers, \&c. This bill originated in the legislative council, and it is worthy of remark that they are enacting here, a law, which in England has been lately repealed, and which Sir Francis Head himself has openly condemned. You remember the outcry which was raised against that provision of the new poor law act, which made women solely answerable for the consequences of their own misconduct-misconduct, into which, in nine cases out of ten, they are betrayed by the conventional license granted to the other sex; but I, as a woman, with a heart full of most compassionate tenderness for the wretched and the erring among my sister women, do still aver that the first step towards our moral emancipation, is that law which shall leave us the sole responsible guardians of our own honor and chastity; it may seem at first view most pitiable that not only the ban of society, but also the legal liabilities, should fall on the least guilty ; and hard indeed will be the fate of many a poor, ignorant delinquent, for the next few years, unless those women who take a generous and extended view of the whole question, be prepared to soften the horrors that will ensue by individual help and acts of mercy; but let the tendency of such enactment, such a public acknowledgment of the 
moral and legal responsibility of women, be once understood, let it once be brought into action, and I am sure the result will be the general benefit and elevation of the whole sex; it brings the only remedy to this hateful mischief which can be brought; the rest remains with ourselves. The best boon we could ask of our masters and legislators, is to be left in all cases responsible for our own actions and onr own debts.

Another act provided two additional judges of the Court of King's Bench, and other law improvements, by which the gaol deliveries were rendered more frequent, and the long and demoralizing imprisonment, previous to trial and conviction, would be shortened. This sounds well. I should observe, that by all accounts the gaols in this province are in a very bad state, and require revision altogether.

Another act established a provincial court of equity, rendered necessary by the nature of the land tenures bere, and to secure in the possession of their property, those whose titles, honestly acquired, were defective from mistake, ignorance, or accident; also to punish frauds and. breaches of trust, beyond the reach of common law. I was rather surprised to find that this act gave to the presiding Chancellor even larger powers than those of the Lord Chancellor at home. It signifies nothing now, when there is nothing on which these powers can be exercised; but it will signify much, fifty or a hundred years hence, as society becomes more, 
complex and artificial, and the rights of property more intricate.

The chancellor will have power to repeal (or, what comes to the same thing, institute proceedings to repeal) all letters patent improvidently granted: an indefinite and dangerous power in bad hands.

Another act was to amend the charter of the University of Upper Canada. The House of Ascombly, in addressing the governor at the opening of the session, had expressed their regret, that " no nseful result had hitherto attended the beneficent intentions of his majesty in granting a charter to King's College, and their hope that the province - would shortly possess the means within itself of beatowing upon the young a refined and liberal educetion."

Next to the clergy reserves, there is no question which has been debated so long and so rehemently, ws this of an endowed university. Forty years ago, in 17.97, the establishment of such an institution was recommended in an address from the provicial legislature to the British government, but it was not till 1828 that the charter was sent over. On this occasion, the legislative council thanked his majesty's government humbly and gratefully for such a munificent proof of paternal regard. The House of Assembly, on the contrary, made their gratitude conditional - " provided that the principles upon which the charter has been founded ehall, upon inquiry, prove to be conducive to the advancement of true learning and piety, and 
friendly to the civil and religious liberty of the people."

In what enight consist " the civil and religious liberty of the people" was not so easily agreed. The first charter, modelled after those of our Eng lish universities, was deemed too exclusive for a young country like this, and became a source of contention and dissatisfaction. The bills to alter and amend the terms of the charter sent up by the House of Assembly, were always thrown out by the legislative council, and thus matters remained until this session. The act just passed abolishes the necessity of any religious test or qualification whatever.in those who enter as scholars, and places the ostablishment under the partial control of the judges and legislature, instead of the exelusive direction of the clergy. The presidency of the university remains with Archdeacon Straban, but for the future the president shall not necessarily hold any ecclesiastical office. Two members of the legislative council have entered a formal protest against this Act; they objected that half of the lands which had been granted for the erection of free grammar schools througbout the different districts, amounting to two hundred and twenty-five. thousand acres, had been given up to the endowment of the university, and that these free-schools not being yet erected, this was a misapplication of the school-lands; and that after such two hundred and twenty-five thousand acres had been applied to the uses of the university, the residue of the schoorlands would not suffice for the purpose of erecting 
free-seminaries, being of a bad quality; nearly eighty thousand acres of the lands originally allotted for the maintenance of schools having been exchanged for other lands of a worse quality, and less: eligibly situated: that the benefits of a good education, instead of being equally diffused through the province, were confined to one large and expensive establishment-too expensive for the population and wants of the country."

Notwithstanding these objections, and the others made by the Tory and bigh church party, the act has passed after vehement debates, and I presume that the erection of the new university will be commenced forthwith.

Another act was for the establishment of agricultural societies, and the encouragement of agriculture in the several districts. There are already agricultural societies in one or two districts, and whenever a certain sum of money was subscribed by the people, for such a purpose, the government assisted them with a further sum of one bundred pounds and upwards.

Various bilks were pessed, voting sums of money for the mending of roads; the improvement of the harbors and light-houses on the lakes; the completion of the great Welland Canal, which unites Lake Ontario with Lake Erie; and the opening of a great northern and western railway to connect Lake $\mathrm{Hu}$ ron with Lake Ontario. All this is very well; but, as $\mathrm{H}$. said this morning, where is the money to come from? It has become difficult to raise loans; and individuals do not willingly speculate in this coun 
try. That all these things will be done at some time or other is certain-certain as that the sun holds his course in heaven, but some changes must take place before speculation on a large scale becomes either secure ur profitable.

A very important act was one introducing an improved system into the land granting department; but the law, as explained to me, remains defective; all the arrangements of our domestic policy are such as to render it difficult and inexpedient for aliens to buy or hold land in this province, and even to British subjects the terms are not so favorable as in the United States. Mr. Prince brought in a bill this session for encouraging settlers from all parts of the world, permitting aliens to acquire and hold lands on easier terms than at present, and to claim the rights of citizenship after a three years' residence.

" Every one," said he, " knows well, though I am almost afraid to mention it in this place, that countless numbers of German, Swiss, and even British emigrants passed, during the summer of 1836 , through Canada to the western parts of the United States, and that none could be prevailed on to stop and settle in this province, though the fertility of the lands, and all other natural advantages, are confessedly greater here, and the distance saved from five to seven hundred miles."*

- The usual route of the emigrants to the New Western States, is through the State of New-York, by the Erie Canal, passing the Niagara River at Queenston, and then through the finest parts of Upper Canada to Detroit, in Michigan. The number of the emigrants and settlers who passed thrôgh $\mathrm{Ca}$. 
This bill was violently opposed, upon the ground that it would introduce, as settlers, an immense number of foreigners bostile to the principles of the British constitution. None denied that it would introduce both population and capital, and that " men, women, and money," being the three vants of the country, it would tend to supply these wants. With regard to the danger to our constitution, from the admission of aliens educated in different principles, one member made some shrewd and pertinent observationg, in a, very homely style. "We profess," said be, " to desire enigration, yet we prohibit virtually nine-tenths of the world from setting their foot on our shores; and why? Because these foreigners, naturally republicans, would naturally overturn our institutions. Now all foreigners are not republicans; the Swiss, Prussians and other Germans, who pass through our country in multitudes, and cannot be persuaded to set up their rest here, are more friendly to our British institutions than to those of the United States; and if it were otherwise, it is a poor compliment to our government and institutions, to say that they suffer from comparison, and that they who have enjoyed any otber will not endure existence under ours. We are told that the Americans offer every inducement to foreigners and British subjects to settle in their new states; and we do not find that the monarchical predilections of these emigrants lead them to disturb the government of their new country," \&c. \&c.

nada to the Western States, in 1835 and 1836, has been estimated at 200,000, 
This bill passed the House of Assembly, and was lost in the Legislative Council. The fate of Texas was adduced as an example of the consequences of suffering foreign capitalists to speculate in the lands of Canada ; but every one agrees that something must be done to attract to the province emigrants of a higher grade than the Scotch and Irish paupers who now locate themselves on small portions of land, and who aid but little in developing the immense resources of this magnificent country. It is in the second generation that this class of people make useful and eligible settlers.

The vital question of the clergy reserves remains as yet unsettled by law ; the motion for establishing fifty-seven endowed rectories within the .province, exercising all powers, and privileges, and jurisdiction, which by the ecclesiastical law belongs to the Church of England, gave rise to a most violent and abusive debate in the House of Assembly, which ended in the motion being lost; but the House resolved, that " the rights acquired under the patente, by which certain rectories have already been endowed, should be considered inviolate.".

An Act, for a limited time, to impose an additional duty on licenses to vend spirituous liquors, can do but little good in the present state of society here. You might as well think to dam up a torrunt with a bundle of reeds, or put out a conflagration with a cup of water, as attempt to put down drunkenness and vice by such trifling measures.

I was in hopes that some Act would have passed this session for the erection of a provincial lunatic 
asylum. At present these unfortunate persons either wander about uncared for, or are shut up in the jails. Instances are known of pauper lunatics straying into the forests, and perishing there. The fate of those confined in the prisons is not better; the malady is prolonged and aggravated by the borrid species of confinement to which, in such places these wretched beings are necessarily subjected. A benevolent physician of this place (Dr. Rees) has offered a block of land a few miles from Toronto for the site of an hospital or asylum for lunatics, but at present it seems the intention of the legislature to take the penitentiary at Kingston for a lunatic aylum, and erect another penitentiary on a different plan. In the moan time this dreadful evil continues-mwst continue for two or three years longer; and think what an amount of individual suffering may be crowded into this period! When I was at Niagara there was a maniac in the jail there, who bad been chained up for four years. Here was misery of the most pitiable kind suffering all the pains and penalties of crime-nay, far more, for the worst criminals had a certain degree of liberty. In the town jail of Toronto, four insane persons are at this time in confinement.

It must be remembered that this state of things is not worse than that which prevailed in rich and civilized England only a fow years ago.

Good night ! for my spirits aro wearied and my fingers are frozen. 
March 6.

As light was the eldest-born principle of the universe, so love was the eldest-born passion of humanity, though people quote Milton to prove that vanity was so-in our own sex at least: and many are the witty sayings on this favorite text; but they are wrong, and their text misinterpreted. Ere, when she looked in passionate delight on ber own lovely face reflected in the stream, knew not it wes her own, and had nothing else to love; the moment she found an Adam on whom to lavish the awakened sympathies, she turned from the shadow to the reality, even though " less winning soft, lese amiably fair:" she did not sit upon the bank and pine to death for her own fair face,

\section{"Like that too beauteous boy,}

That lost himself by loving of himself;"

-while the voice of love wooed her in vain. Vanity in this instance was but the shadow of lore.

But, $\mathrm{O}$ me! how many women since the days of Echo and Narcissus, have pined themeelves into air for the luve of men who were in love only with themselves !

Where the vivacity of the intellect and the strength of the passions, exceed the development of the moral faculties, the character is likely to be embittered or corrupted by extremes, either of adversity or prosperity. This is especially the case

vor. 1. 
with women; but as far as my own observation and experience gu, l should say that many more women have their heads turned by prosperity than their hearts spoiled by adversity; and, in general, the female character rises with the pressure of ill fortune. Sir James Mackintosh says somēwhere, " That almost every woman is either formed in the school or tried by the test of adversity : it may be more necessary to the greatness of the female character than that of men."

And why so ?-I understand the first part of this sentence, but not the last. Why should the test of adversity be more necessary to the greatness of the female character than that of men? The perpetual, and painful, and struggling collision of man with man forms and tries him; woman has little compulwory collision with woman; our equals are our most severe schoolmasters; and the tyranny of circumatances supplies this want to women.

March 8.

Before the languid heart gasp and flutter itself to death, like a bird in an exhausted receiver, let us see what can be done, for something must be done.

This relentless winter seems to stiffen and contract every nerve, and the frost is of that fierceness and intenaity, that it penetrates even to the marrow of one's bones. One of the workmen told me yesorday, that on taking hold of an iron bar it had taken the skin off his band, as if he had grasped it 
red hot : it is a farorite trick with the children to persuade each other to touch with the tongue a piece of metal which has been exposed to the open air; adhesion takes place immediately: even the metal knobs on the doors of the room I carefully avoid touching - tise contact is worse than vnpleasant.

Let but the spring come again, and I will take to moself wings and fly off to the west! But will spring ever come? When I look out upon the bleak, shrouded, changeless scene, there is something so awfully silent, fixed, and immutable in its aspect, that it is enough to disturb one's faith in the overlasting revolutions of the seasons. Green leaves and flowers, and streams that murmur as they flow, woft summer airs, to which we open the panting be som-panting with too much life-shades grate ful for their coolness-can such things be, or do they exist only in poetry and Paradiso?

If it were not for this journalizing, I should fall into a lethargy - as it is I could envy a marmot or a dormouse; and if it were not for my promise to you, I should even abandos this daily noting of daily nothings, of which I begin to be thoroughly asham ed. One day is only distinguishable from another by the degrees of the thermometer. Nor can I, while imprisomed by this relentless climate, seek the companionship and sympathy which stand alooffor no other reason that I can guess-but because I come among them branded with notoriety. I wished to throw open my house in the evening, and break of thew the rocial frost around me; but such 
- aavel and unheard of idea would startle all the inhabitants from their propriety. There must be hore, as elsowhere, kind-bearted, good people, if only they would be natural, and not afraid of each other-and of poor, solitary me. However, in the otrait in which I am placed there is still a remedy.

"Books, dreams, are each a world; and the books we know Are a substantial world."

A world ever at hand. I muet try all mechanical means to maintain the balance of my mind, and the unimpaired use of my faculties, for they will be needed. There is no rescue but in occupation; serious and useful occupation if I can make or find it-trivial occupation when I can not. The desultory reading in which $I$ have lately indulged will never do ; I must look round for something to try my strength-and force and fix my attention. To use my Lord Byron's phrase, I must get " a file for the serpent."

March 10.

I have found a file, or what I will use as such. I shall take to translating.

I brought from Weimar Dr. Ekermann's book," which, as yet, I have only glanced over in parts; by this time it must be well known all over the world of literature. When I left Weimar it was

- Gespräche mit Gozthe. (Conversations with Goäthe.) 
not yot published. There, my attention was strongly directed to this book, not so much by the interest, as by the kind of interest it bad excitod around me. I remember one of Goêthe's grandsons, turning over the leaves as it lay on my table, and exclaiming with animation-" Es ist der Grosspapa selbst! da lebt er!-da spricht er!" (It is grand-papa bimself! - here he lives-he speaks !")

Another, habitually intimate with the domestic life of Goêthe, said, with emotion-" Es ist das Buch von Liebe und Wahrheit." (It is the book of love and truth.)

"Whatever may be in that book," said a dear friend of mind, when she placed it in my hands, "I would pledge myself beforehand for its truth. The mind of Ekermann, at once unsullied and unruffled by all contact with the world, is so constituted, that he could not perceive or speak other than the truth, any more than a perfectly clear and smooth mirror could reflect a false or a distorted image."

Now all this was delightful! The sort of praise one does aot often bear either of a book or a writer -and so, to resd I do most seriously incline. -

I read the preface to-day, and part of the introduction.

In the preface, Ekermann says, very beautifully, "When I think of the fulness, the richness of those communications, which for nine years formed my chief happiness, and now perceive how little of all I have been able to preserve in writing, I feel like a ehild who seeks to catch in his open hands the plen- 
teous showers of spring, and finds that the greatest part has escaped through his fingers."

A little farther on be says- "I am far from believing that $I$ have here unveiled the whole inward being of Goèthe, (der ganze innere Goèthe.) One may liken this most wonderful spirit to a manysided diamond, which in every direction reflected a different bue; and as in his intercourse with different persons, in different positions, he would himself appear different-I can only say modestly - " This is mY Goêthe !"

- This may be said with truth of every character, viewed through the mind of another; of every portrait of the same individual painted by a different artist.

And not only where we bave to deal with marked and distinguished characters, but in the common intercourse of life we should do well to take this distinction into account; and on this principle, I would never judge a character by bearsay, nor venture further, even in my own judgment, than to admit that such a person I like and such another I do not like. In the last case the fault, the deficiency, the cause, whatever it may be, is as probably on my side as on theirs; and though this may sound offensive and arbitrary, it is more just than saying such a one is worthless or disagreeable, for the first I can never know, and as for the latter, the most disagreeable people I ever met with had those who loved them, and thought them, no doubt with reason, very agreeable.

Of a very great, and at the same time complex 
mind, we should be careful not to trust entirely to any one portrait, even though from the life, and of undoubted truth. Johnson, as he appears in Boswell, is, I think, the only perfectly individualized portrait I remember; and hence the various and often inconsistent effect it produces. One moment he is an object of awe, the next of ridicule: we love, we venerate him on this page-on the next we despise, we abhor him. Here he gives out oracles and lessons of wisdom surpassing those of the sages of old; and there we see him grunting over his favorite dish, and "trundling" the meat down his throat like a Hottentot. But in the end, such is the influence of truth, when we can have the whole of it, that we dismiss Johnson like a friend, to whose disagreeable habits and peculiarities we had become accustomed, while his sterling virtues had won our respect and confidence. If 1 bad seen Johnson once, I should probably have no impression, but that made on my imagination by his fame and his austere wisdom, and should remain awe-struck; at the second interview I might have disliked him. But Boswell has given me a friend, and I love the old fellow, though I cannot love his bull-dog manners, and worse than bull-dog prejudices.

Were it possible to have of Goèthe as universal, many-sided, and faithful a picture, it would be something transcendent in interest; but $I$ do not think he had a Boswell near him, nor any one, I imagine, who would be inclined to buy immortality at the same price with that worthy ; at least, Ekermann does not seem such a man.*

- A lady, a near and dear relation of Gosthe, who had lived 
The account of himeolf in the introduction is the most charming little bit of antobiography I have over met with; it is written to account for bis first introduction to, and subsequent intercourse with, Goethe, and is only too short. The perfect simplicity and modesty, yet good taste and even elegance of this little history, are quite captivating. The struggles of a poor German scholar, the secret espirations, the feelings, the sorrows, the toils, the hardships, of a refined and gentle spirit, striving with obscurity and vulgar cares and poverty, are all briefly but graphically touched-a sketch only, yet full of life and truth. Ekermann, it seems, was the son of a poor cottager and pedlar, residing, when

for very many years in the closest communion with him, was pressed by arguments and splendid offers of emolument to give to the world the domestic life of the poet, or at least contribute some notes, with regard to his private conversations and opinions. She refased at once and decidedly. "I had," said she, - several reasons for this. In the first place, I have not a good memory, and I have a very lively imagination: I could not always trust myself. What I should say would be something very near the truth, and very like the truth, but would it be the truth ? How could I send into the world a book, of the exact truth of which I could not in my own conscience, and to my own conviction, be assured ? A second reason was, that Gozthe did not die young; I could not do him any justice he was unable to do himself, by telling the world what he roould have done, what he could have done, or what he had intended to do, if time had been given. He lived long enough to accomplish his own fame. He told the world all he chose the world to know; and if not, is it for me-for me !-to fill up the vacancy, by telling what, perhaps, he never meant to be told ?what I owed to his boundless love and confidence?-that were too horrible!" 
not engaged in his ambulatory traffic, in a little village near Hamburg. Though steeped in porerty. they seem to have been above actual want, and not unbappy. For the first fourteen years of bis life Ekermann was employed in taking care of their only cow, the chief support of the family; gathering wood for firing in the winter; and in summer occasionally assisting his father in carrying tho package of small wares with which be travelled through the neighboring villages. "All this time," says Ekermann, "I was so for from being torment ed by any secret ambition for higher things, or any intuitive longing after science or literature, that 1 did not even know that they existed." In this cace, as in many others, accident, as we call it, developed the latent faculties of a mind of no common order. A woodcut of a galloping horce-the excise stamp, on a paper of tobacco which his father brought from Hamburg-first excited his admiration, and then the wish to imitate what he admired. Ho attempted to copy the horse with a pen and ink; succeeded, much to his own delight and the wonder of bis aim. ple parents; and then by dint of copying some poor ongravings, (lent to him by a potter in the neighbor. bood, who used them to ornament his ware,) be bocame a tolerable draughtsmon; be was then noticed and encouraged by a gentleman, who asked bim if bo should like to become a painter. Now the only idea of a painter which had ever occurred to his father and mother was that of a bouse-painter; and ss they had seen honso-painters at Hamburg wuspended on dangerous scafiolds, when decorating the 
exterior of the buildings there, his tender mother begged him not to think of a trade in which he ran the risk of breaking his neck; and the offer was respectfully declined.

In tho family of the gentleman who noticed him, Ekermann picked up a little French, Latin, and music; and now the thirst for information was awakened in his mind; ho studied with diligence, and, as a clerk in different offices, maintained himcolf till the breaking out of the war of deliverance, in 1813. He then, like every man who could carry a frelock, enrolled bimself in the army, and made the campaigns of 1813 and 1814 . The corps in which he served was marched into Flanders, and there for the first time he had the perception of what pictures are, of all that he had lost in refuaing to bocomo painter, and could have wept, as be says, for very grief and self-reproach. He passed all his leisure in wandering through the churches, gazing on the works of the great Flemish masters. At once the resolution to become an artist took possession of his mind. When his regiment was disbanded, he set to work and placed himself under the tuition of Ramberg, in Hanover. There is something very touching in this part of his history; he had himself nothing in the world-no means of subsistence; but he had a friend in tolerable circumstances at Hanover; ho made his solitary way througb the snow on foot to that city, and took up his residence with this friend of his youth, who shared with him his home and sleuder income. Anxious, howerer, not to be a burthen longer than 
was absolutely necessary, he sought employment, worked so hard as to injure his health, and brought himself to the verge of the grave-in short, he was obliged to give up all hope of studying art as a profession, and he took to literature : here he show. ed the same indefatigable temper, and, conscious of his imperfect education, he put himself to school ; and that he might be enabled to pay for instruction, procured the situation of a clerk in a public office. At the age of twenty-six be became a scholar in the second class of the Gymnasium, among boys of fourteen and fifteen. Here, he says, the most advanced pupils in the school, far from turning him into ridicule, treated him with every mark of respect, and even assisted him in his studies; but between his clerk's office and his schooling, there remained to him scarce one moment either for food or exercise; he was eager to perfect himself in the classics, remained ignorant of the great laws by which he held his existence; and we are not surprised to find that the result of these excessive efforts, was broken health, a constitution almost destroyed, and, in fact, permanently injured. In the midst of all this, Ekermann found time to fall deeply in love; and the wish to obtain distinction and some settled means of subsistence assumed another, a more pleasing, and a more anxious form. But ill-health and a desultory education were against him. He wrote a book of poems, which was published and met with some success; the profits enabled bim to go to a university, where for some time he seems to have entertained the hope of procuring an 
office or a professorship, which should enable him to marry. Thus year after year passed. In the year 1822, he wrote his "Beitráge zur Poesie," (poetical essays,) and sent the uss., with a modest letter, to Goetbe; the result was, an invitation to Weimar, where he finally took up his residence. Some time efterwards he procured a permanent situation, and was enabled to manry the woman he loved; shy by nature, and averse to society, ambitious only of literary distinction, having laid up his whole heart, and hopes, and life, in the quiet pleasures of bis modest home, and in the society of the wife whom he had obtained after a protracted engagement of ten years, Ekermann during the next three years might, perhaps, bo pronounced a happy man. In the third year of his marriage he lost his amiable wife, who died in giving birth to a son, and since that time he has become more shy and inaccessible than evershrinking nervously from the presence of strangers, and devoted to the poor little infant which bas cest him so dear. The daughter-in-law and the grandsons of Goêthe, who look up to him with a tender reverence, be seems to idolize, and has become in some sort the literary Mentor and aid of the young men, as Goêthe had been his long years ago. It is a family tie, every way sanctified, and not, I trust, to be severed in this world by aught that the world can give or take away.

The period at which these conversations commenced was an interesting epoch in the personal existence of Goëthe; it was about the time of his visit to Marienbad, in 1823, and was marked by the 
composition of one of his finest lyrical poems, the elegy in three parts, which he bas entitled, "Trilogie der Leidenschaft." $\mathrm{He}$ is then seventy-four, but in appearance sixty ; his eye still beaming with a softened fire, a cheek yet fresh with health, a well-knit figure, an upright, graceful carriage, a manner which took all hearts captive. The grand, the beautiful old man!-old, yet, alas! still young enough, it seems, in heart and frame, to feel once more, for the last time, the touch of passion; not a mere old man's love, such as we usually see it-half disease, or half infatuation-at best a weakness-the sickly flare of a dying lamp; but genuine passion in all its effects and under its most profound and most painful, as well as its most poetical aspect.

Ekermann merely touches on this subject with all possible, all becoming delicacy ; but there seems no occasion for me to suppress here the mention of some circumstances not generally known, but which can bring nor shame, nor pain, nor regret to any human being.

The object of this love was a young person be had mer at Marienbad-one of the daughters of Madame de $\mathrm{L}-\mathrm{w}$. She has been described to me as fair and rather full-formed, intelligent, accomplished, and altogether most attractive. He began by admiring and petting her as a child-then loved her-loved her against his will, his better sense, one might almost say, against his nature. There was a report in Germany that he had offered her marriage ; this is not true; but it was feared he might do so. He returned from Marienbad changed in manner;

voL. 1 .

12 
he bad lost that majestic calm, that cheerfulness, which inspired such respect as well as affection in those around bim; and for some weeks all were in anxiety for the event. But Goethe was a man of the world, and a man of strong sense; he resolved to free himself from a thraldom of which he felt all the misery and perceived all the ridicule. He struggled manfully, and conquered; but after weeks of terrible suffering and a fit of illness, during which he was seized with a kind of lethargy, a suspension of all memory, perception, feeling, from which be was with difficulty roused : but be conquered; and on his recovery betook himself to his usual remedy for pain and grief-hard work. He found " a file for the serpent," and was soon deep in his new theory of colors and his botanical researches. If there be any one in the world so vulgar-minded and so heartless, as to find in this story of a great poet's last lore, a subject for cruel and coarse pleasantry, I must say that I pity such a being. In the elegy alluded to, we find no trace of the turbulence of youthful passion-no hopes, no wishes, no fears, no desires, no reproaches such as lovers are wont to sing or say. It is no flowery, perfumed wreath of flattery thrown at the feet of a mistress, but rather the funereal incense of a solemn and fated sacrifice. It breathes the profoundest, the saddest tendernessas if in loving be took leave of love. There is nothing in these lines unbecoming to his age, nor discreditable to her, but all is grand, and beautiful, and decorous, and grave, in the feeling and expression. Sometimes, when I read it and think upon its 
truth, tears fill $m y$ eyes even to overflowing, and $m y$ very heart bows down in compassionate reverence, as if I should behold a majestic temple struck by the lightning of heaven and trembling through its whole massy structure. In other moments of calmer reflection, $I$ have considered the result with another kind of interest, as one of the most extraordinary poetical and psychological phenomena in the bistory of human genius.

The first part of this poem is addressed to the shade of Werther, and contains some of the most powerful and harmonious lines he ever wrote; to the second part he has prefixed, as a motto, those beautiful lines in his own Tasso-

Und wenn der Mensch in seiper Qual verstumme Gab mir eia Gott za sagen was ich leide!

Ekermann says, that when Goèthe laid before him this singular poem, he found it distinguished above all the rest of his manuscripts, written with peculiar care in his own neatest hand-writing, on the best paper, and fastened with a silken knot into a red morocco cover. This little piece of fanciful, sentimental dandyism, will bring to your recollection the anecdote of Rousseau binding bis favorite letters in the Heloise with ribbon couleur de rose, and using lapis-lazuli powder to dry the writing. 
March 11.

Went on with Ekermann's book, and found some interesting things.

Ekermann, after he had spent some weeks at Woimar, tells his friend that he was begiuning to feel the favorable influence of a more social life, and in some sort to emerge from the merely ideal and theoretical existence he had hitherto led, \&c. Goethe encourages him, and says strikingly, " Hold fast to the PREsknt. Every position, (zustand,) every moment of life, is of unspeakable value as the representative of a whole eternity."

The following passage is at once very touching and very characteristic. He seems to be a little melancholy, which was not often the case. "When I look back," said Goêthe, " on my early and middle life, and now in my old age reflect how few of those remain who were young with me, life seems to me like a summer residence in a watering-place. When we first arrive, we form friendships with those who have already spent some time there, and must be gone the next week. The loss is painful, but wo connect ourselves with the second generation of visitors, with whom we spend some time and become dearly intimate; but these also depart, and we are left alone with a third set, who arrive just as we are proparing for our departure, in whom we feel little or no interest.

"The world has always regarded me as a peculiar favorite of fortune, nor will I complain of my existence taken as a whole: yet, in truth, it has boen little else than weariness and labor; and I may 
say, that in my five-and-seventy years I have not enjoyed four weeks of peace and comfort-it was the eternal rolling of the stone. The claims upon my time and capabilities, from within and from without, were too many. My only bappiness lay in my poetic talents; yet even in this how have $I$ been, through outward things, disturbed, limited, and hindered! Had I kept myself more apart from public business, and could I have lived more in solitude, I had been happier as a man, and as a poet I had effected much more. Thus, after the publication of my Gotz and my Werther, a certain sensible friend said to me in warning, 'When a man has once done something to delight the world, the world will thenceforward take care that he shall not do it a second time.' A wide-spread name, a high position in society, are doubtless good things, but with all my reputation and my rank, I could not often do more nor better than give way to the opinions of others; and this were in truth but a sorry jest, if I had not therewith so far the advantage, that I learned (erfahre) how others thought: aber sie nicht wie ich."

How solemn sounds all this from the lips of a man, who in years, in fame, in wisdom, in prosperity, exceeded so far his fellow-men!

Pointing out to Ekermann some beautiful antique gems, and comparing them with the manner in which the same subjects and ideas had been treated by modern artists, he makes the oft-repeated observation, how far in these later times we fall short of the classical models : even with the highest feeling for 
the pure inimitable grace, the unaffected nature of those relics, even with a conception of how it was all produced, we cannot repeat the results we admire. "Meyer," he added, " used often to say, "If only it were not so difficult to think;' but the worst is, that all the thinking in the world will not belp us to think -we must go direct to nature, so that beautiful ideas sball present themselves before us like God-sends, (freye kinder Gottes,) and call out to us, - Here we are!" :*

Tiedge, in 1800 , wroto a poem on the immortality of the soul, entitled "Urania," and Goèthe alludes amusingly to the sensat:on it produced for a time; the "Urania" lay on every table-" Uranis" and immortality were the subject of every conversation, and stupid, conceited women discussed round their tea-tables the sublimest speculations on a future life; all which seems to have excited his impatience and his derision. How truly he says somewhere, that the same things are congtantly repeated in the world; that there never whes any thing, any fact, that had only once existed! How well I recollect when the publication of "Satan," and the "Omnipresence of the Deity," and some other poems of the same stamp, were all the rage in England, and sent our evangelical ladies, some up into the clouds, within precincts where seraphs fear to tread, and come down-never mind where-it was Tiedge's " Urania" over again. Of course, I speak bere

- He says the same thing otherwise, and better, in another place-" Alles Geseheite ist schon einmal gedacht worden; man mues nur rersuchen, es noch oinmal zu genken." 
only of the presumption and frivolity, amounting to profaneness and audacity, or worse, which $I$ have witnessed in some women whose heated imaginations outran their reason, as different from the staid, the sober humility of real piety, as the raving Pythoness of old was unlike the meek Mary, "who sat at Jesus' feet and heard his words."

Goêthe says, in the same passage, " that he would not bimself give up for aught in the world the belief in futurity; and he thinks with Lorenzo de Nedici, that he who lives not in the hope of a future life may be counted as already dead; but be exclaims against treating with vulgar and audacious familiarity the divine, the incomprehensible truths, which prophets and apostles touched upon with awe; and I think with him.

Goèthe has (has? -I think of him as being nowo!) I should say, that out of a collection of more than seventy portfolios of engravings and original drawings, it was his general custom to have one or two laid on the table after dinner, and to turn them over in presence of his guests and the ladies of his family, discoursing most eloquently on the different subjects, or pleased to appeal to the natural sense and taste of those around him. It was a divine lecture on art.

There are in one of these portfolios some most exquisite etchings and drawings by Roos, the famous animal painter, all representing sheep or goats in every possible attitude, wonderful for their truth. "When I look at them," says (ioêthe, speaking in the fulness of bis admiration, "I feel a certain 
strange uneasiness. The narrow, stupid, silly, dreamy, yawny nature of these creatures attracts mo into a kind of beastly sympathy with them; I look at them till I am half afraid of becoming a sheep myself, and could almost fancy that the artist had been one; he had no rocation to paint the fiercer quadrupeds, he confined himself to the ruminating animals, and in that he did well : his sympathy with the nature of these creatures was born with him-it was innate."

What would Goethe have thought of some of Edwin Landseer's pictures-bis wild deer-his dogs !-the Highland Nurse, for instance, where the colley is watching by the sleeping infant? Did Roos, or Snyders, or Rubens himself, ever give us the morale of animal life in the fine spirit of Edwin Landseer?

After some other things, Goëthe goes on to say, that he thinks a knowledge of the universe must be innate with some poets. (It seems to have been 80 with Shakspeare.) He says he wrote "Gôtz von Berlichingen" when be was a young inexperienced man of two-and-twenty. "Ten years later," he adds, "I stood astonished at the truth of my own delineation; I had never beheld or experienced the like, therefore the knowledge of these multifarious aspects of human nature $I$ must have possessed through a kind of anticipation."

Yes; the " kind of anticipation" through which Joanua Baillie conceived and wrote her noble tra. gedies. Where did she, whose life has been pure and "retired as noontide dew," find the dark, stern, 
terrible elements, out of which she framed the delineations of character and passion in De Montfort, Ethwald, Basil, Constantine ?-where but in ber own prophetic heart and genius ? - in that intuitive, almost unconscious revelation of the universal nature, which makes the poet, and not experience or knowledge. Joanna Baillie, whose most tender and refined, and womanly and christian spirit never, I believe, admitted an ungentle thought of any living being, created De Montfort, and gave us the physiology of Hatred ; and might well, like Goethe, stand astouished at the truth of ber own delineation.

Farther on, Goëthe speaks of the perfection with which some of the German women write their own language, so as to excel in this particular some of their best authors. The same bolds good in France and England; so that to understand the full force of Goèthe's compliment to his countrywomen, one must recollect-that it is no such easy matter to. write a fine and clear German style, where there are twenty dialects and a hundred different styles. Prince Metternich once observed to me, "What I admire in your language is, that you have one good style in speaking and writing; and all well-bred and well-educated pereons in England speak and write nearly alike. Here, in Germany, we have as many different styles as individual writers, and the difference is greater than a foreigner could easily imagine."

Yet even this kind of individuality, in point of style, may possibly have a value and a charm, and this will be felt if over the rules of a good style bo 
so fixed by criticiom or fashion, that all Germany will write uniformly.

What he says of himself and Tieek is very interesting; he speaks of him with admiration and kind feeling, but adds, "that when the Schlegels set up Tieck as a sort of literary rival to himself, they placed him in a false position. I may say this openly," adds this great man, with a dignified and frank simplicity. "I did not make myself; and it were much the same thing as though I should eren myself with Shakspeare, who also did not make bimself-a being far, far above me, to whom I look up with reverence and wonder."

Driving home one day from Tiefurt, as the carriage turned, they faced the sun just as he was sinking in the west. Goethe ceased speaking, and remained for a fow moments as if lost in thought; then rousing himself, be repeated from some old poet-

"Untergehend sogar ist's immer dieselbige Sonne."

He then continued, with a most cheerful and animated expression - "When a man has lived seventyfive years, he must needs think sometimes upon death. This thought brings me perfect peace, for 1 bave the fixed conviction that the spirit is immortal, and has a never-ceasing progression from eternity- to eternity; it is like the sun, which only seems to set to our earthly eyes, but which in rèality never does set, and never ceases to shine."

Farther on, Ekermann expresses his regret that 
Goèthe should have sacrificed so much time as director of the theatre at Weimar, and considen that many works were thus loat to the world. To which Goèthe replies-" Truly, it is poesible I might have written many good things daring that time; yet when I reflect, I feel no regret. All my productions, as well as endeavors, I have been accustomed to regard as merely aymbolical, (that is, as I uoderstand it, leading to something beyond, and signifi. cant of something better, than tbemselves,) and, in point of fact, it was with me as with a potter, to whom it is quite indifferent whether be makes pitchers or whether he makes platters of his clay."

March 13.

Idle to-day, and although I read a good deal, I translated very little, and noted less.

Yet the following passage struck me. The conversation turned on the German poetesses, and Rehbein, Goeethe's physician, insisted that the poetical talent in women was "ein Art ron geistigem Geschlochtstrieb."

"Hear him!" exclaimed Groethe; "hear the physician, with his ' intellectual impulse of sex!" "

Rehbein explained himself, by observing " that the women who had distinguished themselves in literature, poetry especially, were almost universally women who had been disappointed in their best affections, and sought in this direction of the intel- 
loct a sort of compensation. When women are married, and have children to take care of, they do not often think of writing poetry."

This is not very politely or delicately expressed; but we must not therefore shriuk from it, for it in. volves some important considerations. It is most certain that among the women who have been disringuished in literature, three-fourths have been iither by nature, or fate, or the law of society, placed ia a painful or a false position; it is also most certain that in these days when society is becoming overy day more artificial and more complex, and marriage, as the gentlemen assure us, more and mure expensive, hazardous, and inexpedient, women must find means to fill up the void of existence. Men, our natural protectors, our lawgivers, our masters, throw us upon our own resources; the qualities which they pretend to admire in us-the overflowing, the clinging affections of a warm-heartthe household devotion-the submissive wish to please, that feels "every vanity in fondness lost," the tender shrinking sensitiveness which Adam thought so charming in his Eve-to cultivate these, to make them, by artificial means, the staple of the womanly character, is it not to cultivate a taste for sunshine and roses, in those we send to pass their lives in the arctic zone? We have gone away from nature, and we must, if we can, substitute

- This applies more to Germany than with us, and even up to the present time it has required a very powerful reaction of some kind to drive a German woman into the public path of literature. 
another nature. Art, literature and science, remain to us. Religion, which formerly opened the doors of nunneries and convents to forlorn women, now mingling her beautiful and soothing influence with resources which the prejudices of the world have yet left open to us, teaches us another lesson, that only in utility, such as is left to us, only in the assiduous employpent of such faculties as we are permitted to exercise, can we find health and peace, and compensation for the wasted or repressed impulses and energies more proper to our sex-more natural-perhaps more pleasing to God; but trusting in his mercy, and using the means he has given, we must do the best we can for ourselves and for our sisterhood. The cruel prejudices which would have shut us out from nobler consolation and occupations bave ceased in great part, and will soon be remembered only as the rude, coarse barbarism of a by-gone age. Let us then have no more caricatures of methodistical, card-playing, and acrimonious old maids. Let us hear no more of scandal, parrots, cats, and lap-dogs-or worse ! these never failing subjects of derision with the vulgar and the frivolous, but the source of a thousand compassionate and metancholy feelings in those who can reflect! In the name of humanity and womanhood, let us have no more of them! Coleridge, who has said and written the most beautiful, the most tender, the most reverential things of women-who understands better than any man, any poet, what I will call the metaphysics of love-Coleridge, as you will remember, bas asserted that the perfection of a voL. 1 . 
woman's character is to be characterless. "Every man," said he, " would like to have an Ophelia or a Desdamona for his wife." No doubt ; the sentiment is truly a masculine one; and what was their fate 3 What would now be the fate of such unresisting and confiding angels ? Is this the age of Arcadia? Do we live among Paladins and Sir Charles Grandisons, and are our weakness, and our innocence, and our ignorance, safeguarda-or snares? Do we indeed find our account in being

"Fine by defect, and beautifully weak ?"

No, no; women need in these times character beyond every thing else; the qualities which will enable them to endure and to resist evil; the selfgorerned, the cultivated, active mind, to protect and to maintain ourselves. How many wretched women marry for a maintenamce! How many wretched women sell themselves to dishonor for bread! and there is small difference, if any, in the infamy and the misery! How many unmarried women live in heart-wearing dependence; if poor, in solitary pemury, loveless, joyless, unendeared; if rich, in aimless, pitiful trifling! How many, strange to say, marry for the independence they dare not otherwire claim! But the more patbs opened to us, the less fear that we should go astray.

Surely, it is dangerous, it is wicked, in these days, to follow the old saw, to bring up women to be " happy wires and mothers ;" that is to say, let all her accomplishments, her sentiments, her views of life, take one direction, as if for women there exist- 
ed only one destiny-one bope, one bleaning, one object, one passion in existence; some people $20 y$ it ought to be so, but we know that it is not 80 ; we know that hundreds, that thousands of womes aro not happy wives and mothers-are nover eithor wires or mothers at all. The cultiration of the moral strength and the active energies of a woman's mind, together with the intellectual faculties and tastes, will not make a woman a lese good, bes bappy wife and mother, and will enable ber to find con tent and independence when denied lore and bap. piness.

Got on better to-day.

March 12.

Goèthe speaks with great admiration of the poems, original and translated, of Talvi. (Madamoiselle Jacob, now Mrs. Robinson, and settled, I beliere, in America.)

There is a great deal about Lord Byron in scattered passages. Goèthe seems to have understood him astonishingly well-I mean the man as well as the poet.* At this time Lord Byron was turning all heads in Germany, and Goethe, who was flattered by the veneration and admiration of Byron, felt and acknowledged his genius. " He was," says Ekermann, "quite inexhaustible when once he began to speak

- Lond Byron ist nur gross wenn er dichtet, cobald er reflectirt, iat ex ein kind. 
of Byron," and as a poet bimself, sympathized in the transcendent poetical powers he displayed; but a a philosopher and sage, Goéthe lamented the abuse, the misdirection of the talents he appreciated. He reproaches him with the negative, the gloomy condency of his mind; he contrasts it with the healthful cheerfulness of such a spirit as Shakopeare's. Speaking of his strange attempt to defond and revive the strict law of the drama with regard to the three unities, he says pointedly, " Had be but known as well bow to restrain himself within the fixed moral limits!"

In another place be opeaks with contempt of the poets, imitators of Lord Byron, "who write as if they were all sick, and the whole bright world a lazar house." He says, "It is a real misuse and abuse of poetry, which was given to us to console us in the struggle of life, and make man more content with the world he lives in, not less."

How entirely I sympathize with Goēthe, when he breaks out in indignation against the negative and the satirical in poetry and art! He says, "When I have called the bad-bad, how much is gained by that? The man who would work aright must not deal in censure, must not trouble himself about what is bad, but show and do what is good:" and this is surely true. He says elsewhere, that when there was doubt and contradiction in his mind, he kept it within himself; he gave to the public only the assured result, (or what he considered such,) when he had arrived at it. This firmness of tone, this lofty and cheerful view of the universe and buma- 


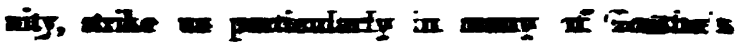

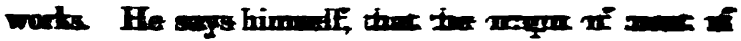

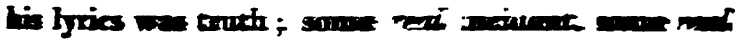

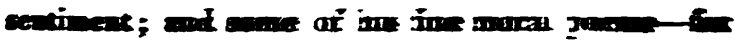

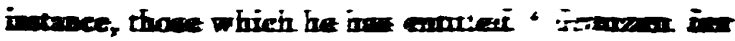

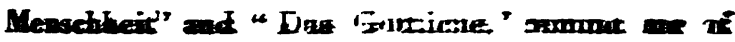
Wordsworth, in the pure jeaitacil iteing a waI

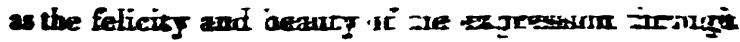
which it has found a cirannei is ine iesers

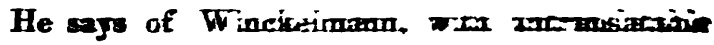

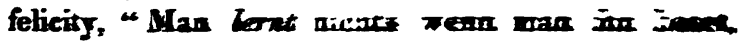
aber man arist exwas "

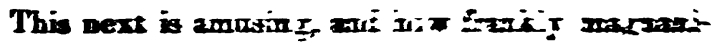
mous! He sajy, "Peiçie tix of or risi-jwhat do they mean I st wosa a we are jore the surrounding world begiss is aperate tpon us and so on to the end. And, äer ai, what an we truly call oar own, bot energy, pover, uniil Coubd I pains out all that I myself oxre to my great forerunners and cotemporaies, truly there woald remain bat little over!"

Goèthe could afford to ans this !

He speats of Schiller so affectionately, and with such a fine, just discrimination of his powers! "All in Schiller was high and great-his deportment, his gait, the mould of his limbs, his least motion, wes dignified and grand -only his eyes were sof." And, adds Goêthe, "like his form was his talent. Wo lived together," be says, " in such close, such daily intimacy, 80 in one anolher, that of many thoughts whigh occur in the works of both, it would be 
gueation whether they originated with the one or the other."

The two great men thns bound together during their lives, were, after Schiller's death, placed in $a$ Lind of rivalship; and still the partisans of the difforent literary factions dispute where no dispute ought to exist. Coleridge says that "Schiller is a thousand times more hearty than Goethe, and that Goethe dues not, nor ever will, command the common mind of the people as Schiller does," I believe it to be true. The reason is, that Schiller bas with him generally the women and the young men, i. e. those whose opinions and feelings are most loudly, most enthusiastically expressed. Goethe, in allusion to this, says playfully, "Now have the public been disputing for these twenty years which of the two is greatest, Schiller or myself! Let them go and be thankful that have two such fellows to dispute about !"

He speaks of the new school of critical historians, who have endeavored to prove that all ancient history is fable.

"Till now," be says, "the world has beliered in the beroism of a Lucretia, a Mutius Scærola, and has been warmed and inspired by the idea. Now comes some historical critic, and assures us that these personages never had a real existence; that it is all fiction and fable, invented by the grand imagination of the old Romans. What have we to do with such pitiful truth! If the Romans were great enough to invent such things, let us at least be great enough to believe in them !" 
Here I should think he was speaking more playfully and feelingly than seriously and critically; and is it not charming?

He goes on-" I used to be delighted with a certain fact in the bistory of the thirteenth century, where the Emperor Frederic II. being engaged against the Pope, all the north of Germany lay open to invaders. The Asiatic hordes advanced even into Silesia, where the Duke of Leignitz defeated them; they turned back to Moravia, there the Count Sternberg beat them. These gallant warriors have hitherto lived in my imagination as the saviours of the German nation. Now comes your historical critic, and he tells me that these beroes sacrificed themselves very unnecessarily, for that of the Turkish army would doubtless have retired of itself-so is a grand patriotic deed lessened and maligned, and one is put horribly out of humor." It is plain that Goethe, like Johnson, did not like to have his faggot disturbed.

He adds, farther on, that in poetry this kind of sceptical criticism is not so mischievous. "Professor Wolf has destroyed Homer, but ho could do nothing to the poem itself, for the Iliad is endued with the miraculous property of the heroes in the Valballa, who, though hewed to pieces in the morning fight, always sit down to dinner with whole limbs."

But there is no end to this-I must stop; yet this about Shakspeare is so beautiful I must have it down.

"How inconceivably rich and great is Shak- 
spearol There is no motive in buman existence which he has not represented and expressed, and with what ease and freedom! One cannot speak of Shakspeare, it is all insufficient. I have in the Wilhelm Meister, groped about him, but it is mere trifling; he is no play-writer, be never thought of a etage; it was too narrow, too paltry a space for his mighty spirit: yes, even the great visible universe itself was for him in space too narrow!

" Nay, he is too rich, ton mighty. A productive poet should read but one piece of his in the year, or he will wreck himself in the vain attempt to reach the unreachable. "I did well," he adds, that in writing my Gotz and my Egmont, I shook him off my shoulders. How many excellent German poets have been destroyed through him and Calderon? for Shakspeare," he adds fancifully, "preeents to us golden apples in cups of silver; through the study of his works we get hold of the cups of silver, but alas, we put potatoes into them."

I close my book, and 80 good night!

Where is he now, be who disappeared and could not bo lost i-sitting with his Shakspeare and his Schiller up there among the stars in colloquy sublime ? and Walter Scott standing by with love and thought upon his spacious brow-What a partic carrée !

- The meaning of the wand motine, in German criticism, should perhaps be explained. It is used to signify any cause out of which the action or consequence aprings. They have the rerb motiviren, and they say of a dramu, or any fiction, that it is well or ill motivirt. 
March 15.

This last paragraph, which I wrote last evening, sent me to bed with my head full of all manner of thoughts and memories and fancies; and not being in a studious mood this miserably cold night, I draw my writing-table close to the fire, and bestow all $\mathrm{my}$ tediousness on you, and if it were twice as much, and you were twice as far off, I would bestow it on you with all my heart-would you not accept the bargain?

I have been much busied to-day with domestic matters, for we are preparing to change our residence for a new house never yet inhabited, and now I am alone in my room. I feel tired, and have fallen into a very dismal and fantastic mood.

Whence and what are we, "that things whose eense we see not, frey us with things that be not?" If $I$ had the heart of that wondrous bird in the Persian tales, which being pressed upon a human heart, obliged that heart to utter truth through the lips, sieeping or waking, then I think I would inquire how far in each bosom exists the belief in the supernatural ? In many minds which I know, and otherwise strong minds, it certainly exists a bidden source of torment ; in others, not stronger, it exists a source of absolute pleasure and excitement. I have known people most wittily ridicule, or gravely discountenance, a belief in spectral appearances, and all the time I could see in their faces that once in their lives at least they had been frightened at their own shadow. The conventional cowardice, the fear of ridicule, even the self-respect which prevents intel- 
ligent persons from revealing the exact truth of what passes through their own minds on this point, deprives us of a means to trace to its sources and develope an interesting branch of Psychology. Between vulgar credulity and exaggeration on the one hand, and the absolute scepticism and materialism of some would-be philosophers on the other, lies a vast space of debateable ground, a sort of twilight region or limbo, through which I do not see my way distinctly. One of the most gifted and accomplished, as well as most rational and most practical characters I ever met with, once said to me seriously, "I thank God I do not believe in the impossibility of any thing."

How far are ourperceptions confined to our outward senses? Can any one tell ? - for that our perceptions are not wholly confined to impressions taken in by the outward senses seems the only one thing proved; and are such sensible impressions the only real ones? When any one asks me gaily the so common and common-place question -common even in these our rational times-" Do you now really believe in ghosts ?" I generally answer as gaily-" I really don't know!" In the common, vulgar meaning of the words, I certainly do not; but in the reality of many things termed imaginary I certainly do.

While I was staying at Weimar, in Goèthe's house, a very pretty little soirée was arranged for me at Madame d'Alefeldt's; there were no cards that evening; and seated round a table we became extremely talkative and confidential, and at last we took to relating ghost stories. It should seem that 
Germany is still like Ireland, the land of the supernatural, as well as the land of romance. There was something quite delightful in the good faitb and the perfect sérieux of some of the narrators, as well as some of the listeners-myself included.

Baron Sternberg gave us a story of an appari. tion at his sister's castle in Livonia ; it was admirable, and most admirably told, thougb, truly, it seemed the last of all apparitions that one would have expected to haunt a castle in Livonia, for it was that of Voltaire.

Then the grand Duke gave us the history of a certain Princess of Rudolstadt, whose picture is at Kochberg, and who, in the estimation of her family, had the gift of prophecy, of seeing visions, and dreaming dreams; but such visions and such dreams-so wild, so poetical, and even so grotesque - shadowing forth the former and future destinies of ber family! and, in truth, the whole story, and the description of the old castle of Rudolstadt, and the old court, and the three old superannuated princesses, like gothic figures woven into tapestryso stately and so stiff, and so ugly, and withal so tinged with the ideal and romantic, were given with so much loveliness of detail, and so much graphic spirit, that 1 was beyond measure amused and interested. I thought I saw them before me, and methinks I see them now.

In return for this tale, I gave from the best authority that of Crofton Croker, the history of the Irish banshee, and particularly of that identical banshee, whose visitations as the hereditary attendant on $\mathrm{my}$ 
own family 1 had painful reason to remember. My banshee pleased universally; to most of the company the idea was something new, and I have even hopes that it may have inspired Sternberg with a pendant to his poem on.King O'Donobue.

The conversation turned naturally upon hereditary apparitions and spectral penances, the fruit of ancestral crimes, on which superstition Grillparzer has founded his fine lyric drama of "The Ahnfrau." The castle of the $W$ - family, in the neighborhood of Weimar, was mentioned as subject to this species of ghostly visitation. Two individuals present, who had been on a visit to this castle, spoke of the phantom avec connaissance de fuit. The preoent Baroness $\mathrm{W}-$, who had been brought up among enlightened and intelligent people, declared herself perfectly incredulous, and after her marriage went to inhabit the castle of her husband, in all the assurance that common sense and philosophy could give; but-so went the tale-it happened that soon after the birth of her eldest child, she awoke at midnight, and beheld an unearthly being bending over the cradle of her infant-mure, as it seemed, in love and benediction than with any unholy purpose; however, from this time they said that she had not willingly inhabited the castle of her husband's ancestors.

In the family of the Baron - whose castle is also in the heighborbood of Weimar, there is a gold ring of marvellous power, given by some supernatural being to a former Baron, with the assurance that as long as it remained in the castle, 
good fortune would attend the family. Every exporiment made of late by unbelieving barons to put this tradition to the test bas been followed by some sigaal disaster, the last time by a destructive fire, which consumed rearly the whole castle. This story also was very well told.

It should seem that in these little German states there was always some ancestor, some prince with a kind of Blue-Beard renown, to serve as the hero for all the tales of horror-the bug-a-boo to frighten the children. Duke Ernest August plays the roble du tyran in the history of Saxe Weimar. He was not only a tyrant, but atheist, alchemist, magician, and heaven knows what besides. Now, there was a profligate adventurer, named Caumartin, who had insinuated himself into the favor of the Duke, became his chamberlain, and assisted him in his magical and chemical researches. It is a tradition, that one of the ancestors of this princely family had discorered the philosopher's stone, and had caused the receipt to be buried with him, denouncing a terrible malediction on whoever should violate, from avaricious mótives, his last repose. Duke Ernest persuaded Cauraartin to descend into the family rault, and pluck the mighty secret from the coffin of his ancestor. Caumartin undertook the task with gay audacity, and remained two hours in the vault. On re-ascending, he looked pale and much changed, and took solemn leave of his friends, as a man condemned to death. They mocked at him of course; but on the third day afterwards he was found dead on the floor of his room, his rapier in his hand, his vox. 1 . 
clothes torn, and his features distorted, as if by a foarfal struggle.

This story so oft repeated in different ages and countries, and in every variety and form, appeared to me curious in a philosophical and bistorical point of view. Duke Eruest Angust lived at the time when a wild superstitious credulity, a belief in magic and alchemy, rose up simultaneously with the most daring scepticism in religious matters, both becoming fashionable in Germany, France, and England, at the same time. It was the reign of Cagliastro and his imitators and disciples. Do you not recollect, in the Baron de Grimm's memoits, the story of a French adventurer, who was received into the first circles of Paris as a supernatural being? He was said to possess the elixir of life, and the wandering Jew was apparently a youth to him in point of longevity. In the house of the Maréchal de Mirepoix he once sat down to the harpsichord, and played a piece of music of sublime and surpassing beauty. All inquired whether it was his own composition, or where it was to be found? To which he replied, with a pensive air-" The last time I heard it was when Alexander the Great entered Babylon!"

Many more stories were told that night of various interest, but all tinged with something poetical and characteristic. . At last the party separated. I returned home, and, while still a little excited, we continued to converse for some time on influence of fancy and its various illusions, and the superstitions of various times and countries. The thing was al- 
ways there, forming, as it seomed, s part of our buman nature; and only modified and changed in ite manifestations, sometimes by outward inflences, sometimes by individual temperament; fachion, or in other words, aympathy and imitation, haviog produced many ghosts, as well as many maniace, and not a few suicides.

At last we bade good night. I lighted my taper, fixed in a candlestick of rather antigue form, the samo whioh had been used when Gotho was chriotened, and which.I.always took in my hand with due reverence. In coming up to my bed-room I hed to pass by the door of the apartment in which Gottho had, breathed his last. It bas been from that moment considered as a sanctuary; the things remain untouched and undisturbed, and the key is depositod with the librarian. In the first or ante-room thero stands-at least when I was at Weimar there stood -a large house-elock, which had been presented to Goêthe on the celebration of his jubilee; it is the same which stood in the room of his mother, and struck the hour he was born : after passing through various hands, it was purchased by the Grand Duke of Baden, and sent as a gift to the poet on that momorable occasion. This clock, like the rest of the furniture of that sacred apartment, remains untouched, but on this very night, by some inexplicable accident, just as I arrived at the door, the clock within began to strike-one, two, three, four, and so on to twelve. At the first stroke I stopped, even my breath almost stopped, as I listened. I looked not to the left, where the door opened into that hallowed 
chamber of death and immortality ; I looked not to the right, where the dark hollow of the staircase seomed to yawn-nor yet before me; but, with my eyes fixed on the silver relie I beld in my hand, I stood quite still. The emotion which bound up my powrers in that moment was assuredly the farthest possibly from fear, or aught resembling it-it was only a sound, but it was the same sound and hour which had ushered into the world one of the greatest and most gifted spirits whom God, in his supreme goodness, bad ever sent to enlighten the world, and to enlarge the bounds of human delight and inprovement; it was the same sound and bour which sent it to mingle with the great soul of nature, to be

A voice in all her music, from the moan Of thunder to the song of night's sweet bird; To be a presence to be felt and known In darkness and in light.

And so in the silence and the Ioneliness of the night, as those sounds fell deliberately one by one, they seemed to fill the whole air around me, to enter in at my ears and thrill down to my finger ends, and I saw the light tremble which I held before me. But sense and the power of motion returned. In the next moment $I$ was in my room and seated in HIs chair, with a steady pulse and a calm spirit, glad to breathe again " queen o'er myself,"-my reasonable self; jet would I not bave missed the strange, the overpowering, deliciously awful feelings of those well-remembered moments-no-not for the universe! Short and transient as they have been, they 
henceforth belong to the tissue of my life: were I to live a century, I cannot forget them, nor would I dare to give them expression-if indeed there aro words which could express them.

March 16.

I was idle to-day, and, instead of going on regularly with my book, I turned over the leaves, and dwelt upon passages here and there, as people, when they are nice and are not hungry, capriciously pick out tit-bits.

The attempt to note down all that I would wish to retain in my memory of this delightful book, I find hopeless, quite. At first I fancied it something like Boswell: nothing can be more unlike. The difference betwęen Dr. Juhnson and Goëthe is not greater than the difference between Ekermann and Boswell. Boswell's book is delicious, but the man's personal character is always in the way; we profit often by his indiscretion, but his indiscriminate trifling as often disgusts. Johnson, in his book, is the "great Colossus" bestriding this narrow world, with a Pharos in one hand, and a bundle of darts in the other; but in Ekermann's book Goethe is nothing less than the "Olympian Jupiter," seated at his table and dispensing nectar and ambroeia, while he plays ehild-like with his own lightnings." Boswell's

- There is now a melancholy propriety in the basso relievo over the entrance to Goëthe's apartment, in his house at Wei- 
meddling coxcombry and servility sometimes place his great patron in no very dignified position; and the well-known similes of the monkey on the bear's back, and the puppy in the lion's den, seem hardly too severe. Were $I$ to find a simile for Ekermann, I sbould say he is like a thrush singing under the wing of a great eagle, sometimes overshadowed by his mighty master, but not overdazzled, not overaved by the "terrors of his beak and lightning of bis eycs"-always himself-and, as himself, always amiable, always respectable. His simplicity, his nprightness, and his gentleness, his poetical and artist-like feeling, are always delightful : one must love him for his own sake as well as Goëthe's.

Yet a translation of this book would hardly pleaso in England; it deals in "notions more than in facts," and in speculations and ideas, more than in anecdotes and personalities. It is necessary to take a strong interest in German literature and society, and in the fine arts generally, to care about a great deal of it; it is something like Coleridge's " Tablo Talk," which certainly few Germans would like or understand, though the criticisms and opinions are full of interest for the English reader; but it is yet more dramatic and lively in manner.

When $I$ was first in possession of this book, and referring with delight to some few sentences which caught my attention, a friend of mine, who bad known Goëthe well and long, wrote me, in her own

mar; it represents the empty throne of Jupiter, with the eagle cowering at its foot, and the thunderbolts lying extinguished and idle. 
peculiar style, some very charming things of its character and iutention; the meaning, and as nearly as I can, the words, I must try to render into English.

"Ekermann's book," said she, "is the purest altar that has yet been erected to the fame of Goëthe. In times like these, when the feeling of reverence (Pietat) seems to be fast departing, when a young autbor of talent takes up the pen, as a sort of critical dissecting knife, mangling and prying where once he trembled and adored; when his first endeavor is to fling down that heaviest burthen upon the soul of an egotist-the burthen of admiration for the merits of another, is it not pleasant to meet with such a book as this? And when every thing one reads. is so artificial, so gemacht, so impertinent, is it not delightful to open a book where in every page we feel the pulse-throb of a warm, true heart? I do not know if I am right, but it seerns to me that those who cannot admire, can have notbing in themselves to be admired; then how worthy of admiration must that man be, who thus throws down his whole heart and soul in admiration before the feet of another! the simplicity of this entire abnegation of self lends to it a certain dignity. There is nothing here but truth and love-for Goèthe loved Ekermann, and O! how Ekermann loved Goëthe!

"I can have no critical judgment here, and ought not to have; I can only bear witness to the general truth of the whole-nothing can be truer. I cannot be, like you, struck and charmed by particular pas- 
sages. I was too long a sort of Lady High Trea. surer to be dazzled or astonished now that the caskets are opened. I greet the gems as old acquaintance !"

After this encouraging testimony, I go on with my notes and my translating.

lt appears that Schiller had the notion of a theatre where pieces should be giren occasionally for men only, and Goèthe seems to approve of this: I do not. The two sexes are more than eufficiently separated by different duties and pursuits ; what tends to separate them farther in their amusements cannot be good for either. A theatre for men only would soon become a bear-garden.

At an evening party, some of his own songs, to which Ekermann had composed beautiful music, were sung for him-be was much pleased. When all was over he observed to Ekermann, that the songs out of the "Iivan," seemed to have no longer any connexion with himself : " both what is Oriental and what is impassioned in those songs," said be, " have passed away from me; it is like the cast skin of a snake, which he leaves lying on his path; but the little song ' Um Mitternacht' $t$ remains with me, a living part of my own life."

After several pages on all manner of things, I

- Written when he was more than seventy.

$t$ Written in his early youth. 
find this remark on Schiller: "Through all bis works," said Goethe, "we bave the idea of freedom. And this idea changed its form as the geuius and character of Schiller were progressively developed. In bis early age it was physical freedom, in his latter life the ideal;" and afterwards he says finely. "that is not freedom where we acknowledge nothing above ourselves, but that is freedom, when we can reverence something greater than ourselves."

He.says of La Grange, " be was a cood man, and even through that, he was truly great; for when a good human being is gifted with talents, be will work for the moral benefit of the world, whother be be artist, natural philosopher, poet, or whatever he may be." This is like what Weber wroto to Mendolsohn.

Farther on be says, "All that is great and distinguished must be in the uninority. There have been ministers who had both people and sovereign against them, and yet have accomplished their own great plans; it is not to be hoped that reason will ever be popular. Passion, feeling, may be popular; but reason will be the possession of the few."

March 6.

I bave often thought and felt, that while in Eng. land we have political liberty, we have nothing like the personal and individual freedom, the social liberty of the Germans, even under their worst governments. The passage which follows has, there- 
fore, struck mo particularly. Goêthe, in speaking with approbation of Guizot, quotes bis remark, that " from the old Germans we derive the idea of perconal frendom, which was espocially characteristic of that people, and quite unknown in the ancient republics." "Is not this true ?" said Goethe. "Is be not perfectly right 9 and is not the same idea prevalent among the Germans of our orrn time? From this source sprung the Reformation, and not leas the various complexion of our literature. The continual etriving after originality in our poets, so that each thinks it necessary to make or find a sew path for himself, the isolation * and eccentric habits of our learned men, where each will stand on his ground, and work his aim out of his individual mind, all come from the same cause. The French and the Euglish, on the contrary, hold more together, and the people all imitate one another. There is something uniform in their dress and behavior; thoy are afraid to swerve from a given fashion, to make themselves peculiar or ridiculous. But in Germany every man follows his humor, without troubling himself about others; each man endeavors to suffice to himself; for in each man, as Guizot has well observed, lives the idea of personal and individual freedom, from which proceeds much that is excellent, and also much that is absurd."

This appears to me very true, and must, I think,

- Verisolirung. Isolirung is solitude and separation-what the French call isolemcnt. Verisolirung expresses isolation with its injurious tendency. 
strike every one who has been in Germany, and felt the interest which this kind of individuality imparts to society ; though certainly I have met with travellers who were not a little pot out by it Life, with them, having hitherto flowed on "comme une govette d"huile sur une table de marbre," they know not how to understand the little projections and angles they have to encounter. The women appear affected, and the men quizzical, precisely because the former are natural and the latter original, and all very unlike the ladies and gentlemen they hare left behind, whose minds, like their bodies, are dressed in the same fashion.

When in Germany, I was accustomed to hear Madame de Staël's " De l'Allemagne" mentioned, if mentioned at all, with something worse than contempt, either as forgotten or out of date. Her trite information, her superficial criticisms, ber French prejudices, her feminine rashness, met with no quarter; but think only, what changes of opinion, what revolutions in criticism, have taken place within thirty years! Sir James Mackintosh-rich in all the lore of his age, beyond his age in most respects writes in 1807, (only two or three years before $\mathrm{Ma}$ dame de Stael produced her book,) of German literature and criticism, as a sort of terra incognita, as the navigators of the fifteenth century talked of a western continent, venturing, but with hesitation, to commend Goěthe, and seeming to think his ideas on 
art not guitc despicable- " rather plausible and inge. nious." He mentions the antipathy in France and England against German literature, and speaking of distinguished modern writers, who might be considered as likely to survive their own age, he says, "I comprehend coen Goêthe and Schiller within the pale; and though 1 know that fow, either in France or England, agree with me, I have recourse to the usual consolation of singularity, that my opinion will be more prevalent when I am myself forgotten."

Madame de Staēl first made a breach through what Goêthe bimself called a "Chinese wall of prejudices;" and we may pass through it surely without trampling upon ber who had courage to open the way for.us.

The Germans understand us better than we understand them. To have a far stronger stamp of national character than most other people, yet better to comprehend and appreciate what lies in the national nature of other people, is one of the most interesting characteristics of the Germans. Their language lends itself with wondrous richness and flexibility to translation from every tongue, and their catholic taste embraces all literature, without insisting on any adaptation to their own canons of criticisms or bienséance,

All that Goëthe says of art and artists is admirable-worthy of him who was the greatest critic and connoisseur of his country and age; for instance, what, he says of Claude Lorraine: "His pictures have the highest possible truth, and not a trace of 
reality; he knew the real world in in mintex do tails, and used these details as a meass to expres the fairer world within bis own sool : ad the is the true ideal, where real neams are so med thet the a parent truth shall produce an i.:asion as if it were reality."

He calls architecture "aime ontarrte mut, expression as untranslatable as it is exc risite.: feficitous. And many other pasuges I leste unsoled with regret.

Yet one thing I muse not omit, for it bas made me think much.

Goêthe appears to consider orr Sarion, with the twelve apostles, as presenting $100 \mathrm{much}$ uniforming to be a good subject for scu!pture. The remark may possibly refer to the fammus brmazes of Peter Vischer on the tomb of St. Sibald at Nuremburg. I was struck by the rariety and discrimination exhibited in these figares; yet, on recollection, the variety was in the drapery and attitude-in the external, not internal character. It were easy to distinguish in eculpture two such opposite characters as St. John and St. Paal; but how are we to distinguish St. Andrew and St. Simon, except by an external attribute, as that of giving St. Peter the keys, and St. Bartholomew his own skin over hiv arm, as at Milan? How make St. Thomes look incredulous? So that, on the whole, there must by something characterless in such a group.

Goethe says, that be had selected from the scriptures a cyclus of twelve figures as strited to sentip-

ror. 1. 
ture, and prosenting all together the history of our religion.

1. ADAM, as the first man and father of mankind $\rightarrow$ type of human grandeur and perfection. He should have a spade, as the first cultivator of the oarth; and to express his character of progenitor and parent, he should be accompanied by a child, looking up to him with a bold confiding glance-a kind of boyish Hercules, crushing a snake in his hand; (perbaps with reference to the promise.)

2. NOAB, the beginner of a new creation, as a vine-dresser, who, by the introduction of the grape, relieved the cares and made glad the heart of man.

3. Moszs, as the first lawgiver.

1. After him, lsaiah, as prince and prophet.

5. Danier, as the harbinger of the Messiah.

6. Christ, as Saviour and Redeomer.

7. JoHn.

8. The Canturion of Capernaum, as representing the believer, the Christian.

9. Next, the Marx Magduenz, as the symbol of humanity, reconciled to God through repentance. These two figures, Faith and Repentance, representing the spirit of Cbristianity.

10. Next, St. Pavi, as promulgator of its doc. trine.

11. Then St. James, as the first missionary, representing the diffusion of Christianity among strange lands.

12. Lastly, St. Pexre, as keeper of the gate of salration. He should have an inquiring, penetrating expression, as if demanding of those who presented 
themselves, whether they were worthy to enter the kingdom of heaven.

"What do you think of this my cyclus?" added Goêthe; "I think it would 'be richer in expression and contrast than the twelve apostles. The Moses and the Magdalene should be seated."

He says that he composed the witch scene in the "Faust," in the Borghese Gardens at Rome. If ever I visit those gardens again, what a strange association will now mingle itself with those antique statues, and fountains, and classical temples!

There is a great deal about his new theory of colors, which I read with interest, but dare not meddle with, because I do not quite understand all. This theory, it seems, is intended to supersede Newton's theory of light and colors : whether it will or not is another thing; but as the savans in France have taken it up, I suppose it will be looked into by our own philosophers; and, meantime, whichever way the question may be decided hereafter, Goêthe's own foeling on the subject will be referred to with interest, either as a curious instance of selfdelusion, or a sublime anticipation of future glory. "On what I have done as a poet," said he, "I would not presume much-I do not pique myself on it"-(hear this!)-“"excellent poets have lived as my contemporaries-more excellent before meand others will live after me; but that, in my own age, I am the only one who, in the profound science of colors, has obtained a knowledge of the truthin that I do give myself some credit-in that only 1 have a consciousness of superiority over many." 
This is somothing like the grand, calm, self-exultation of Milton. Is it as well founded?-Methinks I should like to know.

Ho speaks in varions places of the unseen, imperceptible influences of all outward things in forming the genius and character. "Surely," he says, "the man who has passed all his life long beneath the lofty serious oak, will be a very different man from him who has lived beneath the shade of the myrtle and the willow."

He says, feelingly, "It is not good for man to be alome, aud, above all, it is not good for man to work alone; he requires sympathy, encouragement, excitoment, to succeed in any thing good : in this way I may thauk Schiller for some of my best ballads; and you may take the credit to yourself," he adds kindly to Ekermann, "if ever I finish the second part of Faust."

There is a great deal all through the second rolume relating to the second part of the Faust, which occupied Goethe during the last years of his life, and which he finished at the age of eighty-two. On completing it he says, "Now I may consider the remainder of my existence as a free gift, and it is indifferent whether I do any thing more or not;" as if he had considered his whole former life as beld conditionally, binding him to execute certain objects to which he believed himself called. He survived the completion of the Faust only one year.

The purport of the second part of Faust has puzzled many German and English scholars, and in Germany there are already treatises and commen: 
taries on it, as on the Divina Commedia I nevor read it, and, if I had, wonld not certainly renture an opinion " where doctors disagree ;" but I recollect that Von Hammer once gare me, in his clear animated manner, a comprehensire analysis of this wonderful production- that is, according to his ones interpretation of it. "I regard it," said he, "as being from beginning to end a grand poetical piece of irony on the whole universe, which is turned, as it were, wrong side out. In this point of riew I mderstand it; in any other point of riew it appears to me incomprehensible. It contains some of the most splendid passages be has written."

Every where Goethe speaks of Sir Walter Scott with the utmost enthusiasm of admiration, as the greatest writer of his time; he speaks of him as boing without his like, as without his equal.

I remember Goethe's daughter-in-law saying to me playfully, "When my father got bold of one of Scott's romances, there was no speaking to him till he had finished the third volume: he was worse than any girl at a boarding-school with ber first novel!"

I have particular pleasure in noting this, because I have seen in several English papers and reviews a passage from some book of travels in which Goethe, on what authority I know not, is reprosented as holding Sir Walter Scott in the utmost contempt. This is altogether false; jet the same passage I have lately seen translated into American papers, and thence into the papers of Upper and Lower Canada. Thus over the whole reading world 
is the beliof diffused, that one great genius could oither be wrotchedly mistaken or enviously unjust in eatimating anotber great genius-a belief as dishonorable to genius and human nature, as it is consolatory to the common cry of curs, to ignorant mediocrity, "for folly loves the martyrdom of fame." $I$ beld in my own hands - read with mine own eyes $\rightarrow$ long letter addressed by Sir Waker to Guetthe, giving an account of bis own family, his pursuits, ecen as friend to friend, and expressive of the utmost reverence, as well as gratitude for marks of kind. neas and approbation received fiom Gozthe.

"A lie," says the Chinese proverb, " has no feet, it cannot stand;" but it has wings and can ty fast and far enough. I only wish that truth may be able to follow it, and undo the mischief thus donethrough some unintentional mistake perhaps,-but not the less mischief and injustice.

The following beautiful and original interpretation of Goethe's ballad of the "Erl-King" is not in Ekermann's hook; but never mind, I give it to you in the words in which it was giren to me.

“Goêthe's 'Erl-König' is a poral allegory of deep meaning, though $I$ am not sure he meeant it as such, or intended all that it signifies.

"There are beings in the world who see, who. $f(e \in l$, with a finer sense than that granted to other mortals. They see the spiritual, the imaginative wrrow, or dangęr, or tẹrror which threatens them; 
and those who see not with the same eyes, talk reason and philosophy to them. The poor.frightened child cries out for aid, for mercy; and Papa Wisdom-worldly wisdom-answers,

" "Mein Sahn, es ist ein Nebelotrief"

"Or,

" "Ess scheinen die alten Weiden so grau!"

"It is only the vapor-wreath, or the gray willows waving, and tells him to be quiet! At last the poor child of feeling is found dead in the arms of Wisdom, from causes which no one else perceived-or believed! Is it not often so ?"

What Goethe says of false and true tendencies of mind, and the mistaking a tendency for a talent, deserves attention; it is a mistake we often fall into, both with regard to ourselves and others.

He says, smiling, " People think that a man must needs grow old, in order to be wise; the truth is, that as years increase upon us, we have enough to do to be as good and as wise as we have been. * * In certain things a man is as likely to be in the right at twenty as at sixty."

On this point there is much more, to which I subscribe heartily.

On the subject of religion I find this beautiful comparison, but am not sure whether it be Ekermann's 
or Gosthe's. "A connoisseur standing before the picture of a great master will regard it as a whole. He knows how to combine instantly the scattered parts into the general effect; the universal, as well a the individual, is to him animated. He has no preference for certain portions : he does not ask why this or that face is beautiful or otherwise; why this part is light, that dark; only be requires that all shall be in the right place, and according to the just rules of art; but place an ignorant person before such a picture, and you will see that the great design of the whole will either be orerlooked by him, or confuse him utterly. Some small portion will attract him, another will offend him, and in the ond be will dwell upon some trifling object which is familiar to him, and praise this helmet, or that feather, as being well executed."

“ We men, before the great picture of the destinies of the universe, play the part of such dunces, such novices in art. Here we are attracted by a bright spot, a graceful configuration; there we are repelled by a deep shadaw, a painful object; the immense whole bewilders and perplexes us; we seek in vain to penetrate the leading idea of that great Being, who designed the whole upon a plan which our limited human intellect cannot comprehend."

When Goèthe was more than eighty, be purchased for the first time, an easy chair. His indifference, and even contempt for the most ordinary comforts 
and luxuries of this kind, were amusing, The furniture of his study and bed-room (still preserved as he left them) is of the most homely description. A common deal table, a wooden desk, and a high stool, the very sight of which gave me a pain in $\mathrm{my}$ back, were the only conveniences. He used to say, that never being accustomed from his youth to luxuries and fine furniture, they took his attention from his work. But his drawing-room was elegant-I remember two very large frames, in which be was accustomed to dispose a variety of original drawings by the old masters, perbaps eight or ten in each. When they had hung some time, he changed them for another set. These were his luxuries : the set of drawings which he last selected, remain hanging in the room.

The anecdote related by Ekermann of the Roman cobbler who used an antique head of one of the Cæesars as a block to hammer his leather on, reminds me that the head of the Ilioneus was put tu a similar use by a cobbler at Prague.

The most extraordinary thing in this book is what Goèthe calls " Das Dåmonische." I have (I believe) a kind of glimmering of what he means : whatever exercises a power, a fascination over the mind, whatever in intellect or nature is inexplicable, whatever seems to have a spiritual existence apart from all understood or received laws, acknowle Iged as irresistible, yet mocking all reason to explain it a kind of intellectual electricity or magnetism-in short, "hat ' $\mathrm{ve}$ is unaccountable-he classes under the general head of "Das Dămonische;" a very 
convenient way, and truly a very poetical way, of getting rid of what one does not comprehend. It is, be says, as if "the curtain was drawn away from the background of existence." In things, he instances as examples of this Damonische, music in itself and in its effect on the mind; poetry of the highest order; and in characters he instances Shakspeare, Napoleon, Byron, the late Grand Duke, (his friend, Karl August,) and others. But it is dangerous almost to go on playing thus with his and one's own deepest, wildest thoughts - and I cannot follow them.

There are passages scattered up and down this book, which clearly prove that Goêthe never considered himself as one called upon to take a part in the revolutions and political struggles of his time; but because he stood calmly on the " shore of peace with uuwet eye," and let the giddy torrent whirl past him, shall we infer that he took no beed of its course? Can we think that this great and gifted being, whose ample ken embraced a universe, had neither sympathies in the grandest interests, nor hopes in the brightest destinies, of humanity? It were a profanation to think thus :

"Although his heart (so near allied to earth)

Cannot but pity the perplexed state

Of troublous and distressed mortality,

That thus make way unto the ugly berth

Of their own sorrows, and do still beget

Afliction upon imbecility:

Yet seeing thus the course of things must run, He looks thereon not strange, but as foredone."

- Daniel. 
(Even while these lines were printing, Thomas Carlyle has observed, with equal truth and eloquence, "That to ask of such a mind as Goetho's, that he should mix himself up with the political turmoils of the day, was as if we should call down the moon from the firmament of heaven, and convert her into a street torch.")

Great and worthy of all gratitude and fame wero those men, who have devoted their best faculties, poured out their best blood, for the cause of freedom, for the land they called their own, the principles they espoused ; but greater far and more worthy of gratitude, and of purer and more enduring fame, the very fow, who lived not for an age, a country, but for all ages-for all mankind; who did not live to preach up this or that theory, to sustain this or that sect or party, to insist on this or that truth, but who lived to work out the intellectual and spiritual good, and promote the progress of the whole human race -to kindle within the individual mind the light which is true freedom, or leads to it. Such was the example left by Josus Christ-such a man was Shakspeare-such a man was Goéthe.

March 18.

I have before me the list of criminals tried at the spring assizes here, and the mayor's charge to the jury.

The calendar (for Toronto only) contains fortysix. 
For larcenies, twenty-seven.

Receiving stolen goods, five.

Taking up gonds under false pretences, one.

Assaults, seren.

Keeping disorderly bouses, six.

The mayor, in his charge to the jury, complains of the increase of crime, and of poverty, wretchedness, and disease, (the natural eauses of crime,) within the bounds of the city, and particularly of the increase of street beggars and jurenile depredators, and he recommends the erection of a house of industry on a large scale.

Before we can estimate the increase in the number of criminals as the increase of crime, we must look to the increase of the population, which is enormous. The whole population of Upper $\mathrm{Ca}$ nada has doubled in about nine years, the general average increase per annum being 18,712 ; that of Torunto has doubled within five years. The whole number of criminal convictions for the city of Toronto only, from the spring assizes of 1832 to the assizes of the present year, (1837.) is four hundred and twenty-four men and twenty-five women; of the former ten were for murder, and twenty-three for manslaughter and other violent crimes; and among the women, two were for manslaughter, all the rest were for larcenies and petty crimes.

These are very imperfect data, and quite useless where we wish to come at results; nor can I suc. ceed in getting copies of the yearly calendars in the

- In 1837, the entire population of Upper Canada was estimated at 375,000 . 
various districts to compare with the yearly increase of the population; the officials are all too busy, and know nothing except in their own peculiar department ; the difficulty of obtaining correct information of any kind is beyond what you can conceive; and this, too, where there is no want of good-nature, and the most obliging intentions; but labor is here the state of existence; no one has leisure apparently to interest himself about any thing but what concerns his own business and subsistence.

March 28.

About a week ago we removed into a new house, and I have since been too much occupied to go on with my studies, domestic matters having "possessed me wholly." Our present residence has never yet been inhabited, and is not quite finished. It will be very pretty and pleasant, no doubt, when it is not so very cold and comfortless. We are surrounded by a garden of some extent-or, rather, what will be a garden at some future time; at present it is a bleak waste of snow; we are so completely blockaded by ice and mud, that to reach the house-door is a matter of some difficulty and even danger. Planks laid from one snow heap to another form the only access to the house-door. The site, though now so dreary, must be charming in summer, for we command, at one glance, the entrance to the bay, the King's Pier, the lighthouse, and beyond, the whole expanse of Lake Ontario to vox. 1. 
the Niagara shore, which in some particular states of the atmosphere is distinctly visible, though distant nearly thirty miles. They say, that in clear summer mornings, the cloud of spray rising from the Falls can be seen from this point. There is yet no indication of the approach of spring, and $I$ find it more than ever difficult to keep myself warm. Nothing in myself or around me feels or looks like home. How much is comprised in that little word! May it but please God to preserve to me all that I love! But, $\mathbf{O}$ absence! how much is comprised in that word too! it is death of the heart and darkness of the soul; it is the ever-springing, ever-dying hope; the ever-craving, never-having wish; it is fear, and doubt, and sorrow, and pain;-a state in which the past swallows up the present, and the future becomes the past befure it arrires!

It is now seven weeks since the date of the last letters from my dear far-distant home. The archdeacon told me, by way of comfort, that when he came to settle in this country, there was only one mail-post from England in the course of a whole year, and it was called, as if in mockery, "The Express;" now, either by way of New-York or Halifax, we have a post almost every day.

March :29.

To those who see only with their eyes, the distant is always indistinct and little, becoming less and 
less as it recedes, till utterly lost; but to the imagination, which thus reverses the perspective of the senses, the far off is great and imposing, the magnitude increasing with the distance.

I amused myself this morning with that most charming bouk "The Doctor;"-it is not the second nor the third time of reading. How delicious it is wherever it opens!-how brimful of erudition and wit, and how rich in thought, and sentiment, and humor! but containing assumptions, and opinions, and prognostications, in which I would not believe; -no, not for the world!

Southey's is a mind at which I must needs admire; he stands upon a vast height, as upon a pinnacle of learning; he commands all around an immense, a boundless prospect over whatever human intellect and capacity has achieved or may achieve; but, from the peculiar construction of his mind, he obstinately looks but one way-back to the past, to what has been done; if ever he looks to the future, he merely glances at it sideways.

If I might, like Solomon, ask a gift of God, I would profit by his mistake. I would not ask a wise and an understanding heart : for what did his wisdom and his understanding do for him? They brought him to the conclusion, that all under the sun was vanity and vexation of spirit, and that the increase of knowledge was the increase of sorrow, and so the end was epicurism, despair, and idolatry. 
"O most lame and impotent conclusion!" No!I would ask, were it pormitted, for a simple beart, that should not deceive itself or others, but seek truth for its own sake, and, having found truth, find also goodness and happiness, which must follow to complete the moral barmonic chord.

We are so accustomed to the artificial atmosphere round us, that we lose sometimes the power of distinguishing the false from the true, till we call in our natural instinets to do for us what our perverted reason cannot. They say that the Queen of Sheba once presented before Solomon two garlands of flowers, and desired him to pronounce which was the vatural, which the artificial wreath. The wisdom of this wisest of men did not enable him to do this by the appearance only, so exquisitely had art imitated nature, till on seeing a bee fluttering near, he called it to his aid. The little creature at once settled the question by alighting on the real flowers, and avoiding the false ones.

We have instincts as true as those of the bee to refuse the evil and to choose the good, if we did not smother them up with nonsense and metaphysics.

How true what Southey says! (the Doctor I mean -I beg his pardon,) - "We make the greater part of the evil circumstances in which we are placed, and then we fit ourselves for those circumstances by a process of degradation, the effect of which most people see in the classes below them, though they may not be conscious that it is operating in a different manner, but with equal foree, upon themselves." 
The effect of those pre-ordained evilo-if they are such-which we inherit with our mortal state; inevitable death-the separation from those we love -old age with its wants, its feebleness, its helplessness-those sufferings which are in the course of nature, are quite sufficient in the infliction, or in the fear of them, to keep the spirit chastened, and the reflecting mind humble before God. But what I do deprecate, is to hear people preaching resignation to social, self-created evils; fitting, or trying to fit, their own natures by "a process of degradation" to circumstances which they ought to resist, and which they do inwardly resist, keeping up a constant, wearing, impotent strife between the life that is within and the life that is without. How constantly do I read this in the countenances of those I meet in the world! - They do not know themselves why there should be this perpetual uneasiness, this jarring and discord within; but it is the vain struggle of the soul, which God created in his own image, to fit its strong, immortal nature for the society which men have framed after their own devices. A vain struggle it is! succeeding only in appearance, never in reality, -so we walk about the world the masks of ourselves, pitying each other. When we meet truth we are as much astonished as I used to be at the carnival, when, in the midst of a crowd of fantastic, lifeless, painted faces, I met with some one who had plucked away his mask and stuck it in his het, and looked out upon me with the real human smile. 
Custom is a mere face, or rather a mere mask: as opinion is a mere voice-or less-the echo of a voice.

The Aurora Borealis is of almost nightly occurrence, but this evening it has been more than usually resplendent; radiating up from the north, and spreading to the east and west in form like a fan, the lower point of a pale white, then yellow, amber, orange, successively, and the extremities of a glowing crimson, intense, yet most delicate, like the heart of an unblown rose. It shifted its form and hue at every moment, flashing and waving like a banner in the breeze; and through this portentous veil, transparent as light itself, the stars shone out with a calm and steady brightness; and I thought, as I looked upon them, of a character we both know, where, like those fair stars, the intellectual powers shine serenely bright through a veil of passions, fancies, and caprices. It is most awfully beautiful! $I$ have been standing at my window watching its orolutions, till it is no longer night, but morning.

April I.

So, there is another month gone; and the snows are just beginning to-disappear, and the flocks of snow-birds with them; and the ice is breaking up at the entrance of the bay, and one or two little ves- 
sels have ventured as far as the King's Wharf; and the wind blows strong to dry up the melting snow, and some time or other, perhaps, spring will come, and this long winter's imprisonment will be at an end. Yes; I have been spoiled during these last years-I have been existing only for, and by, the highest faculties of my being-bave lived through admiration, hope, and love, "until aversion and contempt were things I only knew by name;" and now another time is come-how ill, how very ill I bear it !

This is the worst season in Canada. The roads are breaking up, and nearly impassable; lands are flooded, and in low situations there is much sickness, particularly ague. 'We have still sixteen square miles of ice within the bay.

The market at Toronto is not well supplied,-and is at a great distance from us. The higher class of people are supplied with provisions from their own lands and farms, or by certain persons they know and employ. With a little management and forethought, we now get on very well; but at first we had to suffer great inconvenience. Quantities of salted provisions are still imported into the country for the consumption of the soldiers and distant settlers, and at certain seasone-at present, for example-there is some difficulty in procuring any thing else.

Our table, however, is pretty well supplied. Beef is tolerable, but lean; mutton bad, scarce, and dearer than beef; pork excellent and delicate, being fattened principally on Indian corn. The fish is of many various kinds, and delicious. During the 
whole winter wo hed black-bass and white-fish, caught in holes in the ice, and brought down by the Indians. Venison, game, and wild fowl are always to be had; the quails, which are caught in immense numbers near Toronto, are most delicate eating; I lived on them when I could eat nothing else. What they call partridge bere is a small species of pheasant, also very good; and now we are promised snipes and woodcocks in abundance. The wild goose is also excellent eating when well cooked, but the old proverb about Heaven sending meat, \&c. \&c. is verified here. Those who have farms near the city, or a country establishment of their own, raise poultry and vegetables for their own table. As yet I bave seen no vegetables whatever but potatoes; even in the best seasons they are not readily to be procured in the market. Every year, however, as Torouto increases in population and importance, will diminish these minor inconveniences.

The want of good servants is a more serious evil. I could amuse you with an account of the petty miseries we have been enduring from this cause, the strange characters who come to offer themselves, and the wages required. Almost all the servants are of the lower class of Irish emigrants, in general honest, warm-hearted, and willing; but never baving seen any thing but want, dirt, and reckless misery at home, they are not the most eligible persons to trust with the cleanliness and comfort of one's household. Yet we make as many complaints, and express as much surprise at their deficiencies, as though it were possible it could be otherwise. We give to our man- 
servant eight dollars a month, to the cook six dollars, and to the housemaid four; but these are lower wages than are usual for good and experienced servants, who might indeed command almost any wages here, where all labor is high priced.

A carriage of some kind is bere one of the necessaries of life, but a light English built carriage would be quite unfit for the conntry-absolutely nseless. There is, however, an excellent coachmaker here, who has turned out some very pretty equipagesboth sleighs and barouches - of the build which is calculated for the roads in the neighborhood.

There are other good shops in the town, and one, that of the apothecary, worthy of Regent-street in its appearance. The importations of china, glass, hardware, and clothing, arrive from England in thespring and autumn, the seasons for making our purchases. All these articles are much dearer than in England, and there is little choice as to taste or fashion. Two years ago we bought our books at the same shop where we bought our shoes, our spades, our sugar, and salt pork; now we have two good booksellers' shops, and at one of these a circulating library of two or three hundred volumes of common novels. As soon as there is a demand for something better, there will be a supply of course; but, as I said before, we must have time. Archdeacon Strahan and Chief Justice Robinson have very pretty libraries, but in general it is about two years before a new work of any importance finds its way here; the American reprints of the English revieurs and magasines, and the Albion newspaper, seem to supply amply our literary wants. 
Apropos to newspapers-my table is covered with them. In the absence or scarcity of books, they are the principal merlium of knowledge and communication in Upper Canada. There is no stamp-act here-no duty on paper; and I have sometimes thought that the great number of local newspapers which do not circulate beyond their own little town or district, must, from the vulgar, narrow tone of many of them, do mischief; but on the whole, perbaps, they do more good. Paragraphs printed from English or American papers, on subjects of general interest, the summary of political events, extracts from books or magazines, are copied from one paper into another, till they have travelled round the country. It is true that a great deal of base, vulgar, inflammatory party feeling is also circulated by the same means; but, on the whole, I should not like to see the number or circulation of the district papers checked. There are about forty published in Upper Canada; of these, three are religious, viz. the "Christian Guardian," "The Wesleyan Adrocate," and "The Church ;" a paper in the German language is published at Berlin, in the Gore district, for the use of the German settlers ; "The Correspondent and Advocate" is the leading radical, "The Toronto Patriot," the leading Conservative paper. The newspapers of Lower Canada and the United States are circulated in great numbers; and as they pay postage, it is no inconsiderable item in the revenue of the post-office. In some of tbese provincial papers I have seen articles written with considerable talent; amongst other 
things, 1 have remarked a series of letters signed Evans, addressed to the Canadians on the subject of an education fitted for an agricultural people, and written with infinite good sense and kindly feeling; these have been copied from one paper into another, and circulated widely; no doubt they will do good. Last year the number of newspapers circulated through the post-office, and paying postage, was

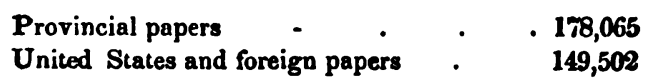

Add 100,000 papers stamped or free, here are 427,567 papers circulated yearly among a population of 370,000 , of whom, perhaps, one in fifty can read;-this is pretty well. The gross receipts of the post-office are $21,000 l$. a year. It is rather affecting to see the long lists of unclaimed letters lying at the post-offiee, and read the advertisements in the Canada and American journals for husbands, relatives, friends, lost or strayed.

There is a commercial news-room in the city of Toronto, and this is absolutely the only place of assembly or amusement, except the taverns and low drinking-houses. An attempt has been made to found a mechanics' institute and a literary club; but as yet they create little interest, and are very ill supported.

If the sympathy for literature and science be small, that for music is less. Owing to the exertions of an intelligent musician here, some voices have been so far drilled that the psalms and anthems at church are very tolerably performed; but this gentleman 
receives $s 0$ little general encouragement, that he is at this moment preparing to go over to the United States. The archdeacon is collecting subscriptions to pay for an organ which is to cost a thousand pounds; if the money were expended in aid of a singing-school, it would do more good.

The interior of the episcopal church here is rather elegant, with the exception of a huge window of painted glass which cost $500 l$, and is in a vile, tawdry taste.

Besides the episcopal church, the Presbyterians, Methodists, Roman Catholics, and Baptists have each a place of worship. There is also an African church for the negroes.

The hospital, a large brick building, is yet too small for the increasing size of the city. The public grammar-school, called the "Upper Canada College," forms a cluster of ugly brick buildings ; and although the system of education there appears narrow and defective, yet it is a beginning, and certainly productive of good.

The physician I have mentioned to you, Dr. Rees, entertains the idea of founding a house of reception for destitute female emigrants on their arrival in Canada-a house, where, without depending on charity, they may be boarded and lodged at the smallest possible cost, and respectably protected till they can procure employment. You may easily imagine that I take a deep interest in this design.

There you have the result of a walk I took this morning up and down our city with a very intelligent guide. 


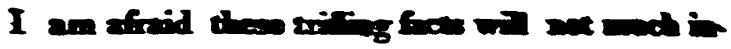

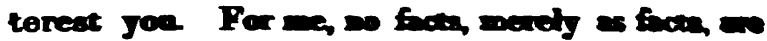

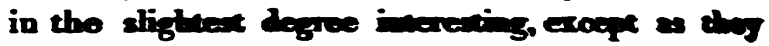

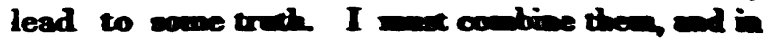

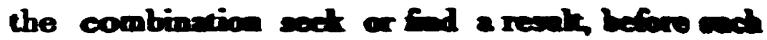
facts excite cielber wy cariosing or andion.

\section{April IS.}

The ice in the bay of Torosto bes been, during the winter monthes, from foar to fire feot in thickness : within the best fer days it has boen cracking in every direction with strange noises, and last night, during a tremendous gale from the east, it was rent, and loosened, and driven at once out of the buy. "It moveth altogether, if it move at all." The last time I drove across the bay, the ice beneath me ap. peared as fixed and firm as the foundations of the earth, and within twelve hours it has disappeared.

To-day the first steam-boat of the season entored our harbor. They called me to the window to 000 it, as, with flags and streamers flying, and amid the cheers of the people, it swept majestically into the bay. I sympathized with the general rejoicing, for 1 can fully understand all the animation and buntle which the opening of the navigation will bring to our torpid capital.

In former times, when people travelled into etrange countries, they travelled de bonne foi, really vox. $x$. 
w wo and learn what was now to them. Now, when travoller goes to a foreign country, it is wwaye with a set of preconcoived notions concerning it, to which he fits all he sees, and refers all be hears $f$ and this, I suppuse, is the reason that the old travellere are still safe guides; while modern travellers may be pleasant reading, but are withal the most unsafo guides any one can have.

I am inclined to distrust the judgment of those persons whom I see occupied by one subject, one ides, one object, and referring all things to that, till it aseumes by degrees an undue magnitude and importance, and prevents them from feeling the true relotive proportion and value of other objects : yet thus it is, perhaps, that single truths are worked out and perfected. Yet, again, I doubt whether there $b c$ soparate and single truths - whether it be possible for one to arrive at the truth by any nurrow path;or is truth, like heaven, "a palace with many doors," to which we arrive by many paths, each thinking his own the right one; and it is not till we have arrived within the sanctuary that we perceive we are in a central point to which converge a thousand various paths from every point of the compassevery region of thought?

In the Pitti Palace at Florence there is a statue, standing alone in its naked beauty, in the centre of a - many-sided saloon, panelled with mirrors, in which it is reflected at once in every different aspect, and in each, though differeutly, yet truly, as long as the 
mirror bo clear and unwroped and ach is the Wo all look towands in, bat each mind belolls is under a different angle of incidence; and malen wo were so freed from all canthly bonds as to bebold in one and the same moment the statue itself, in its pure unvarying oneresen, and all its wotriplied and ever-varying reflections imaged anound, bow aball we presume to settle which of these is the falce, and which the true?

To reason from analogy is ofien dangerona, but to illustrate by a fanciful analogy is sometimes a moans by which we light an idea, as it were, into the understanding of another.

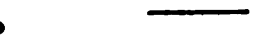

April 22.

The King of Pruevis, after seeing Othello, forbade Desdemona to be murdered for the future, and the catastropho wras altered accordingly - " by his majesty's command" This good-natured monarch, whose ideas of art are quite singular, also insisted that in the opera of Undine, Huldibrand should not dio as in the tale, but becomo a water-spirit, and "all end happily;" but I would not advise you to langh at this, as long as we endure the new catartrophes tacked to Shakspeare.

It was Hoffmann, so celebrated for his tales of diablerio, and in Germany not less celebrated as a mnsician, who composed the opera of Undine. The masic, as I have been aseured, was delicious, and received at Borlin with rapturous approral. Aftor the fint few representations, the opera-house wes bernt dowe, and with it the more of the Undino 
perished. Hoffmann bad accidentally one partie in his dook, but in the excess of his rage and despair be threw that also into the fire, and thus not a note of this charming opera survires.

Only the other day I was reading Hoffmann's analysis and exposition of the Don Juan. It is certainly one of the wildest, and yet one of the most beantiful, pieces of criticism I ever met with-the criticism of an inspired poet and musician. Methinks that in this opera the words and the music are as body and soul; and certainly we must judge the character and signification of the whole by the music, not by the words. Hoffmann regards Don Juan as a kind of Faust, and insists that Donna Anna was in love with him; and the music given to ber expresses certainly a depth of passion and depair beyond the words, and something differen irom them. The text speaks the conventional woman, and the music breathes the voice of nature revealing the struggle, the tempest within.

When at New-York this winter, I was introduced to a fine old Italian, with long and flowing white hair, and 8 most venerable and marked physiogno. my; it was Lorenzo da Porta, the man who bad first introduced Mozart to the Emperor Joseph, and who wrote for him the text of the Don Juan, the Figaro, and the Cosi fan Tutti : we have no such libretti now!

The German text of the Zauberflote was by Schichenada, a buffoon comedian and singer in the ser'vice of Joseph II.; he was himself the original Papageuo. Some people think that he meant to dramatize in this opera the mysteries of Freemaconry, and othors are anxious to find in it some pro- 


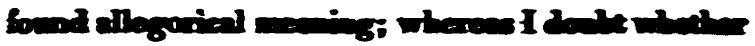

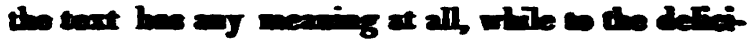

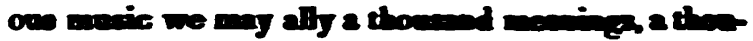

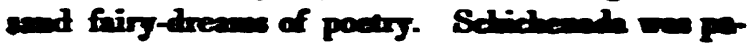

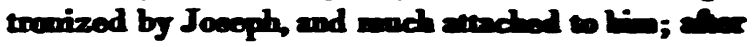
the emperor's death, ho went med, and eppont the

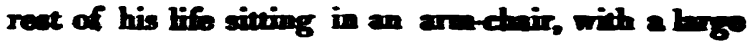
shoet thrown all orer him, refoxing to spealk to Li $^{\circ}$ family. When any one visited him be would Ef the sheet from his boed, and as, with a fred bols, "Did you know Joseph q" If the answer were "Yes," he would, perhapes, condescend to axchenge a fow wonds with his risitor-always on the was sabject, his emperor and patron; but if the answer were "No," he immediately drew bis shect about him like a shrond, hid his face, and sank anin ives his arm-chair and obstinnte silonoe: and thes bo diel.

April ia

Thisday, after very cold weather during the whols weok, the air became fillod with a hase like omoles the wind blow suddenly hot as from the mouth of a farnace, and for a fow hours I suffered oxceedingly from languid depression, and could scarcoly breetha It wes worse than an Italian sirocca.

I.cannot learn the cause of this phenomenon : the wind blew from the lake.

Mas 1:

Exceedingly cold, - a severe frost-a keen, boir terous wind, and a most turbulent lake. Too ill 20 $17^{*}$ 
do anj thing but read. I amused mysolf with Friedrich Ruckert's poems," which left on my imagination an impression like that which the perfume of a boquet of hot-house flowers, or the sparkling of a cakkt of jewrels, would leave on my senses. As an amatory lyric poet, he may be compared to Moore ; -there is the same sort of efforescence of wit and fancy, the same felicity of expression, the same gemliko polish, and brilliance, and epigrammatic.turn in his exquisite little lyrics. I suppose there could not bo a greater contrast than between his. songs and those, of Heino. It is greater than the difference between Moore and Burns, and the same kind of difference.

Lenau, $\nmid$ again, is altogether distinct; and how charming he is! Yet great as is his fame in Germany, I believe it has not reached England. $H e$ is the great pastoral poet of modern Germany-not pastoral in the old-fashioned style, for he trails no sbepherd's crook, and pipes no song "to Amaryllis in the shade," nor does he deal in Fauns or Dryads, and such "cattle." He is the priest of Nature, her Druid, and the expounder of her divinest oracles. It is not the poet who describes or comments on nature ;-it is Nature, with her deep mysterious voice, commenting on the passions and sorrows of humanity. His style is very difficult, but very expressive

- Friedrich Rückert is professor of the Orientul languages at Erlangen. He has published three volume of poems, partly origibal, and partly translated or imitated from eastern poets, and enjoys a very high reputation both as a scholar and a poet.

+ Nicholaus Lenau is a noble Hungarian, a Magyar by birth : the name under which his poetry is published is not, I believe, his neal name. 


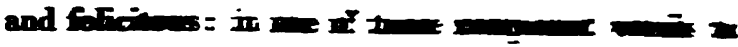
which the Gow The

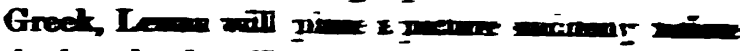

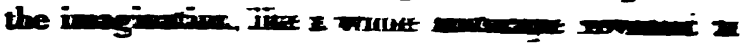

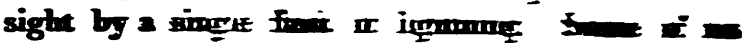

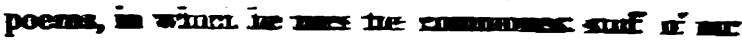

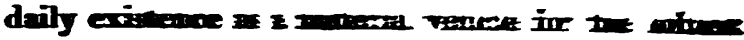

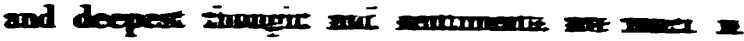
the mar of म

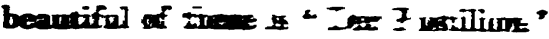

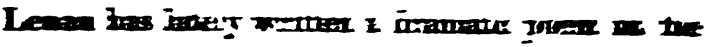

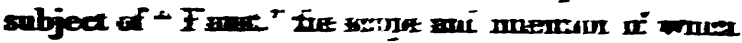

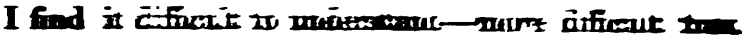

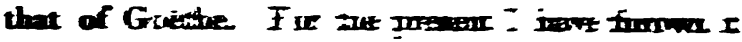
aride in despir.

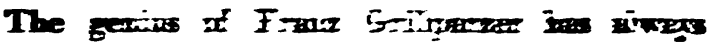

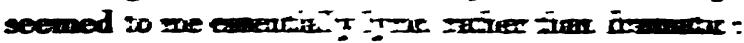

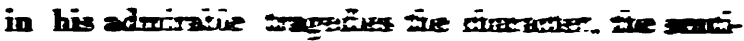

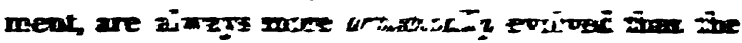
siturtica or sation.

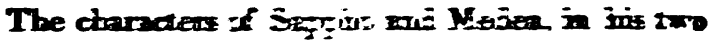

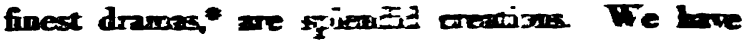

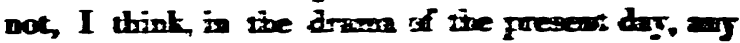
thing conceived with oognt porrer, and at the sene time carried cent in exerg part, and set fucth with

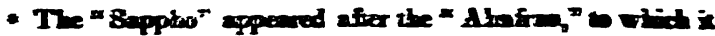

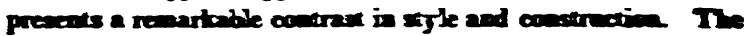
"Golten Fleces, is throe parts, appeared in 1822 Bech thes tragolies bare been represested on all the theotres in Germans; and Madane Wolf a Berlin, Xadane Beysondorf a Weimar, Modane Sehroeder as Munich and Viesan, bave all excellnd as Sappho and Moden 
such glocions poctionl coloring. Loend Byron's "Sandanapalno" would give perhaps a more just iden of the menmer is which Grillparzer treets a dramatio subjoct, than any thing olse in our literatare to which I could compare him.

Bappho is tho type of the woman of genius. Sthe entern crowned with the Olympic laurel, surrounded by the shouts of gratulating crowds, and shrinks within herself to find that they bring her incense, not happiness-applause, not sympathy-fame, not love. She would fain renew ber youth, the golden dreams of her morning of life, before she had soundod the depths of grief and passion, before experience had thrown its shadow over her heart, in the love of the youthful, inexperienced, joyous Phaon; and it is well imagined too, that while we are filled with deepest admiration and compassion for Sappho, betrayed and raging like a Pythoness, we yet have aymathy for the boy Phaon, who leaves the love of his magnificent mistress-love rather bestowed than yielded-for that of the fair, gentle slave Melitta. His first love is the woman to whom he does homage; his second, the woman to whom he gives protection. Nothing can be more natural; it is the common course of things.

Loarned and unlearned agree in admiring Grillparzer's versification of Sappho's celebrated ode-

"Golden-Thronende Aphrodite!"

-It sounds to my unlearned ears wonderfully grand and Greek, and musical and classical : and when Schroeder recites these lines in the theatre, you 
might hear your own heart beat in the brenthless silence around."

German critics consider the "Medea" low perfect than the "Sappho" in point of style, and, conaidered merely as a work of art, inferior. Of this I cannot so well judge, but I shall never forget reading it for the first time-I think of it as an ere in my poetic reminiscences. It is the only conception of the character in which we anderstand the roces sity for Medea's murder of ber children. In the other tragedies on the same subject, we mout take it for granted; but Grillparzer conducts as to the appalling catastrophe through such a linked cbain of motives and feelings, that when it comes, it comes as something ineritable.

Medea is the type of the woman of inatinct and passion. Contrasted with the elegant, subdued Greek females, she is a half sarage, all devotion and obedience one moment, a tameless tigress in the next; first subdued by the masculine valour, then revolted by the moral cowrardice of Jason. Grillparzer has wisely kept the rirago and the sorcerese, with whom we hardly sympathize, out of sight as much as possible; whilo the human being, humanly acted upon and humanly acting and foeling, is for ever before us. There is a dreadful truth and na-

- The translation of the same ode by Ambrose Phillips,

" $O$ Venus !' beauty of the skies,

To whom a thousand temples rise,"

is well known. In spite of the commendation bestowed on it by Addison, it appears very trivial and affocted, compared with that of Grillparzer. 
ture in the whole pirtrait, which is perfectly finished throughout. Placed beside the Medea of Euripides, it is the picturesque compared with the statuesque delineation.

The subject of the "Medea" has a strange fascination around it, like that of the terrible agonized beeuty of the "Medusa," on which we must gaze though it turn us to stone. It has been treated in overy possible style, in I know not how many tragedies and operas, ancient and modern. I remember, at Vienna, a representation of a singular kind given by Madame Schroeder; it was a monologue in prose, with musical symphonies, composed by George Benda, about 1755. After every two or three spoken sentences came a strain of music, which the actress accompanied by expressive pantomime. The prose text (by Gotter) appeared to me a string of adjurations, exclamations, and imprecations, without any coloring of puetry; and the music interrupted rather than aided the flow of the passion. Still it was a most striking exhibition of Schroeder's peculiar talent; her fine classical attitudes were a study for an artist, and there were bursts of pathos, and flashes of inconceivable majesty, which thrilled me. The fierceness was better expressed than the tenderness of the woman, and the adjuration to Hecate recalled for a moment Mrs. Siddons's voice and look when she read the witch-scene in "Macbeth;" yet, take her altogether, she was not so fine as Pasta in tho same character. Schroeder's Lady Macbeth I remember thinking insufferable. 
May 19.

After some days of rather severe indisposition from ague and fever, able to sit up.

Sat at the window drawing, or rather not drawing, but with a pencil in my hand. This beautiful Lake Ontario!-my lake-for I begin to bo in love with it, and look on it as mine!-it changed its hues every moment, the shades of purple and green fleeting over it, now dark, now lustrous, now pale-like a dolphin dying; or, to use a more exact though less poetical comparison, dappled, and varying like the back of a mackerel, with every now and then a streak of silver light dividing the shades of green : maguificent, tumultuous clouds came rolling round the horizon; and the little graceful schooners, falling into every beautiful attitude, and catching every variety of light and shade, came curtseying into the bay : and flights of, wild geese, and great black loons, were skimming, diving, sporting over the bosom of the lake; and beautiful little unknown birds, in gorgeous plumage of crimson and black, were fluttering about the garden : all life, and light, and beauty were abroad-the resurrection of Nature! How beautiful it was! how dearly welcome to my senses -to my heart-this spring which comes at last-so long wished for, so long waited for!

\section{May 30.}

Last night, a ball at the government-house, to which people came from a distance of fifty-a hundred-two hundred miles-which is nothing to signify here. There were very pretty girls, and very nice dancing; but wo had all too much reason to 
lament the loas of the band of the 66th regiment, which left us a fow weeks ago-to my Borrow.

It is to be hoped that all the governors sent here for the future may be married men, and bring their wives with them, for the presence of a female at the head of our little provincial court-particularly if the bo intelligent, good-natured, and accomplished -is a greater advantage to the society here, and does more to render the government popular, than you can well imagine.

Erindale.

-A very pretty place, with a very pretty name. A kind invitation led me hither, to seek change of air, change of scene, and every other change I most needed.

The Britannia steam-boat, which plies daily between Toronto and Hamilton, brought us to the mouth of the Credit River in an hour and a half. By the orders of Mr. $M * *$, a spring cart or wagon, the usual vehicle of the country, was waiting by the inn, on the shore of the lake, to convey me through the woods to his house; and the master of the inn, a decent, respectable man, drove the wagon. He had left England a mere child, thirty years ago, with his father, mother, and seven brothers and sisters, and eighteen years ago had come to Canada from the United States, at the suggestion of a relation, to settle "in the bush," the common term for uncleared land; at that time they had nothing, as he said, but " bealth and hands." The family, now reduced to five, are all doing well. He has himself a farm of two hundred and fifty acres, his own property; his 
brother as much more; his sisters are well settled. "Any man," said be, "with health and a pair of bands, could get on well in this country, if it were not for the drink; that ruins hundreds."

They are forming a harbor at the mouth of the river-widening and deepening the channel; but, owing to the want of means and money during the present perplexities, the works are not going on. There is a clean, tidy inn, and some log and frame houses; the situation is low, swampy, and I should suppose unhealthy; but they assured me, that though still subject to ague and fever in the spring, every year diminished this inconvenience, as the draining and clearing of the lands around was proceeding rapidly.

The River Credit is so called, because in ancient times (i.e. forty or fifty years ago) the fur traders met the Indians on its banks, and delivered to them on credit the goods for which, the following year, they received the value, or rather ten times the value, in skins. In a country where there is no law of debtor or creditor, no bonds, stamps, bills, or bailiffs, no possibility of punishing, or even catching a refractory or fraudulent debtor, but, on the contrary, every possibility of being tomahawked by said debtor, this might seem a hazardous arrangement; yet $I$ have been assured by those long engaged in the trade, both in the upper and lower province, that for an Indian to break his engagements, is a thing unheard of : and if, by any personal accident, be should be prevented from bringing in the stipulated number of beaver skins, his relatives and friends consider

vol. 1.

18 
their honor implicated, and make up the quantity for him.

The for trade has long ceased upon these shores, once the scene of bloody conflicts between the $\mathrm{Bu}$. rons and the Missassaguas. The latter were at length nearly extirpated; a wretched, degenerate remnant of the tribe still continued to skulk about their old haunts and the burial-place of their fathers, which is a high mound on the west bank of the river, and close upon the lake. These were collected by the Methodist missionaries, into a village or settlement, about two miles farther on, where an attempt has been made to civilize and convert them. The government have expended a large sum in aid of this charitable purpose, and about fifty log-huts have been constructed for the Indians, each hut being divided by a partition, and capable of lodging two or more families. There is also a chapel and a school-house. Peter Jones, otherwise Kabkewaquonaby, a half-cast Indian, is the second chief and religious teacher; he was in England a few years ago to raise contributions for his people, and married a young enthusiastic English woman with a small property. She has recently quitted the village to return to Euxope. There is, besides, a regular Methodist preacher established here, who cannot speak one word of the language of the natives, nor hold any eommunion with them, except through an interpreter. He complained of the mortality among the children, and the yearly diminution of numbers in the settlement. The greater number of those who remain are halfbreeds, and of these, some of the young women and chil- 
dren are really splendid creatures; but the general appearance of the place and people struck me as gloomy. The Indians, whom I saw wandering and longing about, and the squaws wrapped in dirty blankets, with their long black hair falling over their faces and eyes, filled me with compassion. When the tribe were first gathered together, they amounted to se. ven hundred men, women, and children; there aro now about two hundred and twenty. The missionary and his wife looked dejected; be told me that the Conference never allowed them (the missionaries) to remain with any congregation long enough to know the people, or take a personal interest in their wel fare. In general the term of their residence in any settlement or district was from two to three years, and they were then exchanged for another. Among the inhabitants a few have cultivated the portion of land allotted to them, and live in comparative comfort; three or four women (half cast) are favorably distinguished by the cleanliness of their bouses, and general good conduct; and some of the children are romarkably intelligent, and can read both their own language and English ; but these are exceptions, and dirt, indolence, and drunkenness, are but too general. Consumption is the prevalent disease, and earries off numbers * of these wretched people.

After passing the Indian village, we plunged again into the depth of the green forests, through a road or path which presented every now and then ruts and abysses of mud, into which we sank nearly up to the axletree, and I began to appreciate feelingly the fit-

* The notes thrown together here are the result of three differand risita to the Credit, and information otberwise obtained, 
ness of a Canadian wagon. On each side of this forest path the eye sought in vain to penetrate the labyrinth of foliage, and intermingled flowers of every dye, where life in myriad forms was creeping, humming, rustling in the air or on the earth, on which the morning dew still glittered under the thick shades.

From these woods we emerged, after fire or six miles of travelling, and arrived at Springfield, a little village we had passed through in the depth of winter-how different its appearance now! -and diverging from the road, a beautiful path along the high banks above the river Credit, brought us to Erindale, for so Mr. M * *, in fond- recollection of his native country, has named his romantic residence.

Mr. $M * *$ is the clergyman and magistrate of the district, beside being the principal farmer and land proprietor. His wife, sprung from a noble and historical $\mathrm{race}_{2}$ blended much sweetness and frankheartedness, with more of courtegy and manner than I expected to find. My reception was most cordial, though the whole house was in unusual bustle, for it was the 4th of June, parade day, when the district militia were to be turned out; and two of the young men of the family were buckling on swords and accoutrements, and furbishing up belmets, while the sister was officiating with a sister's pride at this military toilette, tying on sashes and arranging epaulettes; and certainly, when they appeared-one in the pretty green costume of a rifleman, the other all covered with embroidery as a cap. tain of lancers-I thought I had seldom seen two 
finer looking men. After taking coffee and refresh ments, we drove down to the scene of action.

On a rising ground above the rirer which ran gurgling and sparkling through the green ravine beneath, the motley troops, about three or four hundred men, were marshalled-no, not marshalled, but scattered in a far more picturesque fashion hither and thither: a few log houses and a saw-mill on the river-bank, and a little wooden church exowning the opposite height, formed the chief features of the scene. The boundless forest spread an around us. A few men, well mounted, and dressed as lancers, in uniforms which were, however, any thing but uniform, flourished backwards on the green sward, to the manifest peril of the spectators; themselves and their borses, equally wild, disorderly, spirited, undisciplined : but this was perfection compared with the infantry. Here there was mo uniformity attempted of dress, of appearance, of movement; a few had coats, others jackets; a greater number had neither coats nor jackets, but appeared in their shirt sleeves, white or checked, or clean or dirty, in edifying variety! Some wore hats, others caps, others their own shaggy heads of hair. Some had firelocks; some had old swords, suspended in belts, or stuck in their waistbands ; but the greater number shouldered sticks or umbrellas. Mrs. $M * * *$ told us that on a former parade day she had heard the word of command given thus-"Gentlemen with the umbrellas, take ground to the right! Gentlemen with the walking-sticks, take ground to the left!" Now they ran after each other, elbowed, 
and kicked each other, straddled, stooped, chattered; and if the commanding officer turned his back for a moment, very coolly sat down on the bank to rest. Not to laugh was impossible, and defied all power of fuce. Charles $M$. made himself hoarse with shouting out orders which no one obeyed, except perhaps, two or three men in the front; and James, with his horsemen, flourished their lances, and galloped, and caperod, and curveted to admiration. James is the popular storekeeper and postmaster of the village, and when, after the show, we went into his warehouse to rest, I was not a little amused to seo our captain of lancers come in, and, taking off his plumed helmet, jump over the counter, to serve one customer to a "pennyworth of tobacco," and another to a " yard of check." Willy, the younger brother, a fine young man, who bad been our cavalier on the field, assisted; and half in jest, half in earnest, I gravely presented myself as the purchaser of something or other, which Willy served out with a laughing gayety and unembarrassed simplicity quite delightful. We returned to sit down to a plain, plenteous, and excellent dinuer; every thing on the table, the wire excepted, was the produce of their own farm. Our wine, water, and butter were iced, and every thing was the best of its kind.

The parade day ended in a drunken bout and a riot, in which, as I was afterwards informed, the cofonel had been knocked down, and one or two serious and even fatal accidents had occurred; but it was all taken so very lightly, so very much as a thing of caurse, in this half civilized community, that I soon ceased to think aboụt the matter. 
The next morning I looked out from my window upon a scene of wild yet tranquil loveliness. The house is built on the edge of a steep bank, (what in Scotland they term a scaur,) perhaps a hundred feet high, and descending precipitously to the rapid river." The banks on either side were clothed with overhanging woods of the sumach, maple, tamarask, birch, in all the rich yet delicate array of the fresh opening year. Beyond, as usual, lay the dark pineforest; and near to the house there were several groups of lofty pines, the original giant-brood of the soil ; beyond these again lay the "clearing." The sky was without a cloud, and the heat intense. I found breakfast laid in the verandah : excellent tea and coffee, rich cream, delicious hot cakes, new-laid eggs-a banquet for a king! The young men and their laborers had been out since sunrise, and the younger ladies of the house were busied in domestic affairs ; the rest of us sat lounging all, the morning in the verandah; and in the intervals of sketching and reading, my kind host and hostess gave me an account of their emigration to this country ten years ago.

Mr. M. was a Protestant clergyman of good family, and had held a considerable living in Ire. land; but such was the disturbed state of the country in which he resided, that he was not only unabler to collect his tithes, but for several years neither his

* In this river the young sportsmen of the family had speared two hundred salmon in a single night. The salmon-hunts in Canada are exactly like that described so vividly in Guy Mannering. The fish thus caught is rather a large species of trout than genuine salmon. The sport is most exciting. 
own life nor that of any of his family was safe. They never went out unarmed, and never went to rest at night without haring barricadoed their house like a fortress. The health of his wife began to fail under this anxiety, and at length, after a severe struggle with old feelings and old habits, he came to the determination to convert his Irish property into ready money and emigrate to Canada, with four fine sons from seven to seventeen years old, and one little daughter. Thus you see that Canada has become an asylum, not only for those who cannot pay tithes, but for those who cannot get them.

Soon after his arrival, he purchased eight hundred acres of land along the banks of the Credit. With the assistance of his sons and a few laborers, he soon cleared a space of ground for a house, in a situation of great natural beauty, but then a perfect wilderness; and with no other aid designed and built it in very pretty taste. Being thus secure of lodging and shelter, they proceeded in their toilsome work-toilsome, most laborious, he allowed it to be, but not unrewarded; and they have now one hundred and fifty acres of land cleared and in cultivation; a noble barn, entirely constructed by his sons, measuring sixty feet long by forty in width; a carpenter's shop, a turning-lathe, in the use of which the old gentleman and one of his sons are very ingenious and effective; a forge ; extensive outhouses ; a farm-yard well stocked; and a house comfortably furnished, much of the ornamental furniture being contrived, carved, turned, by the father and his sons. These young men, who had received in Ireland the rudi- 
ments of a classical education, had all a mechanical genius, and here, with all their energies awakened, and all their physical and mental powers in full occupation, they are a striking example of what may be done by activity and perseverance; they are their own architects, masons, smiths, carpenters, farmers, gardeners; they are, moreover, bold and keen hunters, quick in resource, intelligent, cheerful, united by strong affection, and doating on their gentle sister, who has grown up among these four tall, manly brothers, like a beautiful azalia under the towering and sheltering pines. Then I should add, that one , of the young men knows something of surgery, can bleed or set a broken limb in case of necessity ; while another knows as much of law as exables him to draw up an agreement, and settle the quarrels and arrange the little difficulties of their poorer neighbors, without having recourse to the "attorney."

The whole family appear to have a lively feeling for natural beauty, and a taste for natural history; they know the habits and the haunts of the wild anlmals which people their forest domain; they have made collections of minerals and insects, and have " traced each herb and flower that sips the silvery dew." Not only the stout servant girl, (whom I met running about with a sucking-pig in her arms, looking for its mother,) and the little black boy Alick; -but the animals in the farm-yard, the old favorite mare, the fowls which come trooping round the beniguant old gentleman, or are tbe peculiar pets of the ladies of the family, - the very dogs and cats appear to me, each and all, the most enviable of their species, 
There is an atmosphere of benevolence and cheerfulness breatbing round, which penctrates to my very beart. I know not when I have felt so quietly $\rightarrow 0$ entirely bappy-so full of sympathy $\rightarrow$ so light-heartod-so inclined to shut out the world, and its cares and vanities, and "fleot the time as they did i' the golden age."

In the evening it was very sultry, the sky was magnificently troubled, and the clouds came rolling down, mingling, as it seemed to me, with the pine tops. We walked up and down the verandah, listening to the soft melancholy cry of the whip-poorwill, and watching the evolutions of some beautiful green snakes of a perfectly harmless species, which were gliding after each other along the garden walks; by degrees a brooding silence and thick darkneas fell around us; then the storm burst forth in all its might, the lightning wrapped the whole. borizon round in sheets of flame, the thunder rolled over the forest, and still we lingered-lingered till the fury and tumult of the elements had subsided, and the rain began to fall in torrents; we then went - into the house and had some music. Charles and: Willy had good voices, and much natural taste; and we sang duets and trios till supper-time. We again assembled round the choerful table, where there was infinite laughing - the heart's laugh-and many a jest seasoned with true Irish gallantry and humor; and then the good old gentleman, after discussing his sober tumblor of whiskey-punch, sent us all witb his blessing to our rest. 
Mr. M. told me, that for the first seven or eight years they had all lived and worked together on his farm; but latterly he had reflected that though the proceeds of the farm afforded a subsistence, it did not furnish the means of independence for his sons, so as to enable them to marry and settle in the world. He has therefore established two of his sons as storekeepers, the one in Springfield, the other at Streetsrille, both within a short distance of his own residence, and they have already, by their intelligence, activity, and popular manners, succeeded beyond his hopes.

I could perceive that in taking this step there bad been certain prejudices and feelings to be overcome, on his own part and that of his wife: the family pride of the well-born Irish gentleman, and the antipathy to any thing like trade, once cherished hy a certain class in the old country-these were to be conquered, before he could reconcile himself to the idea of his boys serving out groceries in a Canadian village; but they were overcome. Some lingering of the "old Adam" made him think it necessary to excuse-to aecount for this state of things. He did not know with what entire and approving sympathy I regarded, not the foolish national prejudices of $\mathrm{my}$ country, but the honest, generous spirit and good sense through which be had conquered them, and provided for the future independence of his children.

$I$ inquired concerning the extent of bis parish, and the morals and condition of his parishioners.

He said that on two sides the district under his 
chargo might be considered as without bounds, for, in fact, there was no parish boundary line between him and the North Pole. He has frequently ridden from sixteen to thirty miles to officiate at a marriage or a funeral, or baptize a child, or preach a sermon, wherever a small congregation could be collected together; but latterly his increasing age rendered such exertion difficult. His parish church is in Springfield. When he first took the living, to which be was appointed on his arrival in the country, the salary - for here there are no tithes-was two hundred a year: some late measure, fathered by Mr. Hume, had reduced it to one hundred. He spoke of this without bitterness as regarded himsolf, observing that he was old, and had other means of subsistence ; but be considered it as great injustice both to himself and to his successors-"For," said he, "it is clear that no man could take charge of this extensive district without keeping a good horse and a boy to rub him down. Now, in this country, where wages are high, he could not keep a horse and a servant, and wear a whole coat, for less than one hundred a year. No man, therefore, who had not other resources, could live upon this sum; and no man who had other resources, and had received a fitting education, would be likely to come here, I say nothing of the toil, the fatigue, the deep responsibility-these belong to his vocatinn, in which, though a man must labor, he need not surely starve:-yet starre he must, unless he takes a farm or a store in addition to his cleri- 
cal duties. A clergyman in such circumotances could hardly command the respect of his parishioners : what do you think, madam?

When the question was thus put, I could only think the same : it seems to me that there must be something wrong in the whole of this Canadian church system, from beginning to end.

With regard to the morals of the population around him, he spoke of two things as especially lamentable, the prevalence of drunkenness, and the early severing of parental and family ties; the first, partly owing to the low price of whiskey, the latter to the high price of labor, which rendered it the interest of the young of both sexes to leave their home, and look out and provide for themselves as soon as possible. This fact, and its consequences, atruck him the more painfully, from the contrast it exhibited to the strong femily affections, and respect for parental authority, which even in the midet of squalid, reokless misery and ruin, he had been accustomed to in poor Ireland. The general morats of the women be considered infinitely superior to those of the men; and in the midst of the borrid example and temptation, and one may add, provocation, round them, their habits were generally sober. He knew himself but two females abandoned to habits of intoxication, and in both instances the cause had been the same-an unbappy home and a brutal husband.

He told me many other interesting circumstances and anecdotes, but being of a personal nature, and roz. I. 
his permission not expressly given, I do not note them down here.

On the whole, I shall never forget the few days opent with this excellent family. We bade farewell, after many a cordial eutreaty on their part, many a promise on mine, to visit them again. Charles M. drove me over to the Credit, where we met the steam-boat, and I returned to Toronto with my heart full of kindly feelings, my fancy full of delightful images, and my lap full of flowers, which Charles had gathered for me along the margin of the forest : flowers such as wo transplant and nurture with care in our gardens and green-houses, moat dazzling and lovely in color, strange and new to mo in their forms, and names, and uses; unluckily I am no botanist, so will not venture to particularize farther; but one plant struck me particularly, growing overy where in thousands : the stalk was about two feet in beight, and at the top were two large fan-like leaves, one being always larger than the other; from between the two sprung a single flower, in size and shape somewhat resembling a large wild rose, the petal white, just tinted with a pale plush. The flower is succeeded by an oval-shaped fruit, which is eaten, and makes an excellent preserve. They call it here the May-apple. 


\title{
SUMMER RAMBLES
}

\author{
IN CANADA.
}

You walk, you read, you speculate alone;
Yet doth remembrance, like a sovereign prince,
For you a stately gallery maintain
Of gay or tragic pietures.

Wordwoort.

Vergnügen sitzt in Blumen-kelchen, und kommt allo Jahr einmal als Geruch heraus.

Raul.

Juno 8.

We have already exchanged "the bloom and ravishment of spring" for all the glowing maturity of summer; we gasp with heat, we long for ices, and are planning renetian blinds; and three weeks ago there was snow lying beneath our garden fences, and not a leaf on the trees! In England, when Nature wakes up from her long winter, it is like a sluggard in the morning-she upens one eye and then another, and shivers and draws her snow coverlet over ber face again, and turns round to slumber more than once, before she emerges at last, lazily and slowly, from her winter chamber; but here, no sooner has the sun peoped through her 
curtaina, than up she springs, like a huntress for the chase, and dons ber kirtle of green, and walks abroad in full-blown lifo and beauty. I am basking in ber smile like an insect or a bird! Apropos to birds, wo havo, alen! no singing birds in Canada. There is, indeed, a little creature of the ouzel kind, which haunts my garden, and has a low, sweet warble, to which I listen with pleasure; but we have nothing like the rich, continuous song of the nightingale or lark, or eren the linnet. We have no music in our groves but that of the frogs, which set up such a shrill and perpetual chorus every evening, that we can scarce hear each other speak. The regular manner in which the bass and treble roices respond to each other is perfectly ludicrous, so that in the midst of my impatience I have caught myself laughing. Then we have every possible variety of note, from the piping squeak of the tree-frog, to the deop. guttural croak, almost roar, of the bull-frog.

The other day, while walking near a piece of water, I was startlod by a very loud deep croak, as like the croak of an ordinary frog, as the bellow of a bull is like the bleat of a calf; and looking round, perceived one of those enormous bull frogs of the country seated with great dignity on the end of a plank, and staring at me. The monster was at least a foot in length, with a pair of eyes like spectacles ; on shaking my parasol at him, he plunged to the bottom in a moment. They are quite harmless, I believe, though slander accuses them of attacking the young ducks and chickens.

It would be pleasant, rerily, if, after all my ill- 
bumored and impertinent tirades againet Toronto, I were doomed to leave it with regret; jet such is likely to be the case. There are some most kindhearted and agreeable people here, who look upon mo with more friendliness than at first, and are winning fast upon my feelings, if not on my sympathios. There is considerable beauty too around mo-not that I am going to give you descriptions of scenery, which are always, however eloquent, in some respect failures. Words can no more give you a definite idea of the combination of forms and colors in scenery, than 80 many musical notes : music were, indeed, the better vehicle of the two. Felix Mendelsohn, when a child, used to say, "I cannot tell you how such or such a thing was-I cannot speak it-l will play it to you!" and run to his piano: sound was then to him a more perfect vehicle than words; so, if I were a musician, I would play you Lake Ontario, rather than describe it. Ontario means the beautiful, and the word is worthy of its signification, and the lake is worthy of its beantiful name; yet I can hardly tell you in what this fascination consists : there is no scenery around it, no high lands, no bold shores, no picture to be taken in at once by the eye; the swamp and the forest encloses it, and it is so wide and so vast that it prosents all the monotony without the majesty of the ocean. Yot, like that great ocean, when I lived beside it, the expanse of this lake has become to me like the face of a friend. I have all its varioas expressions by heart. I go down upon the groon bank, or along the King's Pier, which projocts 
about two hundred yards into the bey. I sit these with my book, reading cometimes, but oftoner watching untired the changeful colors as they flit orer the bosom of the lake. Sometimes a thunder-squall from the west sends the little sloops and schooners sweeping and scudding into the harbor for shelter. Sometimes the sunset converts its surface into a ses of molten gold, and sometimes the young moon walks trembling in a path of silver; sometimes a purple haze floats over its bosom like a veil ; sometimes the wind blows strong, and the wild turbid waves come rolling in like breakers, finging themcolves over the pier in wrath and foam, or dancing like spirits in their glee. Nor is the land without come charm. About four miles from Toronto the river Humber comes down between high woodcovered banks, and rusbes into the lake: a more charming situation for villas and garden-houses could hardly he desired than the vicinity of this beautiful little river, and such no doubt we shall $\infty$ in time.

The opposite side of the bay is formed by a long cand-beak, called the "island," though, in fact, no inlend, bux a rery narrow promontory, about three miles in length, and forming a rampart againat tho main waters of the lake. At the extremity is a. light-house, and a few stunted trees and underwood. This mareh, intersected by inlets and covered with seeds, is the haunt of thousands of wild fowl, and of the torapin, or small turtle of the lake; and as evening comes on, we wee long rows of red lights from the fiobing-boets gleaming along the surface of the 
water, for thus they spear the lake salmon, the bass, and the pickereen.

The only road on which it is possible to take a drive with comfort is Young-street, which is macadamised for the first twelve miles. This road leads from Toronto northwards to Lake Simcoe, through a well-settled and fertile country. There are some commodious, and even elegant houses in this neighborhood. Dundas-street, leading west to the London district and Lake Huron, is a very rough road for a carriage, but a most delightful ride. On this side of Toronto you are immediately in the pine forest, which extends with little interruption (except a new settlement rising bere and there) for about fifty miles to Hamilton, which is the next important town. The wooded shores of the lake are very beautiful, and abounding in game. In short a reasonable person might make himself very happy here, if it were not for some few things, among which, those Egyptian plagues, the flies and frogs in summer, and the relentless iron winter, are not the most intolerable : add, perhaps, the prevalence of sickness at certain seasons. At present many families are flying off to Niagara, for two or three days togetKer, for change of air; and I am meditating a flight myself, of such serious extent, that some of my friends here laugh oútright; others look kindly alarmed, and others civilly incredulous. Bad roads, bad inns-or rather no roads, no inns; wild Indians, and white men more savage far than they; dangers and difficulties of every kind are threatened and prognosticated, enough 
to make ono's bair stend on end. To undertake such a journey alowe is rah perhape-yet alone it must be achieved, I find, or not at all; I shall heve neither companion nor man-servant, nor femme do chambre, nor eren a "littlo foot-page," to give notice of my fate, should I be swamped in a bog, or eaten up by a bear, or scalped, or disposed of in some strange way; but shall I leave this fine country without seeing any thing of its great characteristic features ?-and, above all, of its aboriginal inbabitants ? Moral courage will not be wanting, but physical strength may fail, and obstacles, which I cannot anticipate or overcome, may turn me back; Jet the more I consider my project-wild though it bo-the more I feel determined to persist. The French bave a proverb which does honor to their gallantry, and to which, from experience, 1 am inclinod to give full credenco- "Ce que femme vext, Diew veut." Wo shall soe.

June 10.

Mr. Hepburne brought me yesterday the number of the Foreign Review for Februery last, which contains, among other things, a notice of Barou Sternberg's popular and oloquent novels. It is not very well done. It is true, as far as it goes; but it gives no sufficient idea of the general character of bis works, come of which display the wildest and most playful fancy, and others again, pictures, not very attractive ones, of every day social life. 
Sternberg, whom I knew in Germany, in a joung nobleman of Livonia, bandsome in pernos, and of quiet, elegant manners. Yet I remember thet in our first interview, even while be. interested and fixed my attention, he did not quite please me; there was in his conversation something cold, guanded, not flowing; and in the expresoion of bis derk, handsome features, something too imvariable and cynical; but all this thawed or brightesed awey, and I became much interested in bim and bis works.

Sternberg, as an author, may be claced, I thirk, with many other accomplished and popular authors of the day, flourishing bere, in France, and in England, simultaneously - signs of the times in which wo live, taking the form and preseure of the age, not informing it with their own spirit. They are a sot of men who have drunk deep, eren to liceneo, of the follies, the pleasures, and the indulgences of 10 ciety, even while they struggled (some of them at least) with its most bitter, and most vulgar cares. From this gulf the intellect rises, perhaps, in all its primeval strength, the imagination in all its brilliance, the product of both as luxuriant as ever; but we are told,

"That every git of noble origin, Is breathed upon by Hope's perpetual breath !"

And a breath of a different kind has gone orer the works of these writers - $a$ breath as from a lazarbouse. A power is gone from them which nothing can restore, the bealthy, the clear vision, with which 
a frech, pure mind looks round upon the social and the natural world, perceiving the due relations of all things one with another, and beholding the "soul of goodness in things evil ;" these authors, if we are to believe their Gwn account of themselves, given in broad bints, and very intelligible mysterious alluvions, have suffered horribly from the dominion of the passions, from the mortifications of wounded selflove, betrayed confidence, ruined hopes, ill-directed and ill-requited affections, and a long etcetera of micories. They wish us to believe, that in order to produce any thing true and great in art, it is necessary to bave known and gone through all this, to have been dragged through this sink of diseipation, or this fery furnace of ouffering and passion. I don't know. Goetbe, at lesst, did not think so, when he spoke of the "sort of anticipation" through which he produced his Gotz von Berlichingen and his Werther. I hope it is not so. I hope that a knowledge of our human and immortal nature, and the due exercise of our faculties, does not depend on this sort of limited, unbealthy, artificial experience. It is as if a man or woman either, in order to learn the free, natural graceful use of the limbs, were to take lessons of a rope-dancer; but waving this, we see in these writers, that what they. call truth and experience has at least been bought rather dear; they can never again, by all the perfumes of Arabia, sweeten what has been once pollated, nor take the blistering scar from their brow. From their works we rise with admiration, with delight, with astonishment at the talent displayed; with the most excited 
foelings, but never with that blameless as well o vivid sense of plessure, that unreproved delight, that grateful sense of a healing, boly infuence, with which we lay down Shakspeare, Walter Scoth, Wordsworth, Goèthe. Fet what was hidden from these men? Did they not know all that the world, and man, and nature could unfuld? They knew it by "anticipation," by soaring on the wings of ustrammelled thought, far, far abore the turmoil, and looking superior down, and with the ample kew of genius embraced a universe. These moders novel writers appear to me in comparivon like childres, whose imperfect faculties and experience indwes them to tonch erery thing they see; wo they burn or soil their fingers, and the blister and the stain sticks perpetual to their pages-those pages which yet ex melt, or dazzle, or eharm. Nothing that in, or has been, or may be, can they see but through some personal medium. What they have theswelves felt, suffered, seen, is always before them, is mixed up with their fancy, is the material of their exictence, and this gives certainly a degree of vigor, a palpable reality, a life, to all they do, which carries wo away; but a man might as well tbink to view the face of universal nature, to eatch the pure, unmixed, allembracing light of day through one of the gorgeous painted windows of Westminster Abbey, as to perceive abstract moral truth througt the minds of these writers ; but they have their use, ay, and their beauty-like all things in the world-only I would not be one of such. I do not think them enviable either in themselves individuals, or in the imme- 
diate effect they produce, and the sort of applause they exeite; but they have their praise, their merit, their wo-they have their day-hereafter, perhaps, to be remembered as we remember the school of writers before the French revolution; as we think of the wretched slave, or the rash diver, who from the pit or from the whirlpool has snatched some gems worthy to be gathered into Truth's immortal treasury, or wreathed into her diadem of light.

They have their day-how long it will last, how long they will last, is another thing.

To this school of fiction-writing belong many authors of great and various merit, and of very different character and tendencies. Some by true but partial portraitures of social evils boldly aiming at the overthrow of institutions from which they have as individuals suffered; others, through this medium, publicly professing opinions they would hardly dare to promulgate in a drawing-room, and discussing questions of a doubtful or perilous tendency; others, only throwing off, in a manner, the impressions of their own minds, developed in beautiful fictions, without any ultimate object beyond that of being read with sympathy ánd applause-especially by women.

I think Sternberg belongs to the latter class. Ho has written some most charming things. I should not exactly know where to find his prototype: he reminds me of Bulwer sometimes, and one or two of his tales are in Barry St. Leger's best manner-the eloquence, the depth of tragic and passionate interest, are just his; then, again, other remind me of 
Wilson, when be is fanciful and unearthly; but, on the whole, his genius differs essentially from all these.

His comic and fantastic tales are exquisite. The fancy and the bumor run into pathos and poetry, and never into caricature, like some of Hoffmann's.

One of the first things I fell upon was his "Herr von Mondshein," (Master Moonshine,) a little jew d'esprit, on which it seems he sets small value himself, but which is an exquisite thing for all that $\rightarrow 0$ wildly, yet so playfully, so gracefully grotesque! The effect of the whole is really like that of moonlight on a rippled stream, now seen, now lost, now here, now there-it is the moon we see-and then it is not; and yet it is again! and it smiles, and it shines, and it simpers, and it glitters, and it is at once in heaven and on the earth, near and distant, by our side, or peeped at through an astronomer's telescope; now helping off a pair of lovers-then yonder among the stars-and in the end we rub our eyes, and find it is just what it ought to bo-all moon shine!

Superior and altogether different is the tale of "Molière,"-the leading idea of which appeare to mo beautiful.

A physician of celebrity at Paris, the inventor of some famous elixir-half quack, half enthusiast, and something too of a philosopher-finde himself, by some chance, in the parterre at the representation of one of Molière's comedies, in which the whole learned faculty are so ex, uisitely ridiculed; the player who represents the priucipal character, is vec. I. 
order to make the satire more poignant, arrays himself in the habitual dress of Tristan Dieudonne; the unfortunate doctor sees himself reproduced on the stage with every circumstance of ignominious ridicule, hears around him the loud applanse, the laugh of derision-meets in every eye the mocking glance of recognition; his brain turns, and he leaves the theatre a raving maniac. (So far the tale is an "o'er true tale.") By degrees this frenzy subsides into a calmer but more hopeless, more melancholy madnesa; he shuts himself up from mankind, at one time sinking into a gloomy despondency, at another revelling in projects of vengoance against Molière, his enemy and destroyer. One only consolation remains to him ; in this misergble; abject state, a charitable neighbor comes to viait bim daily ; by degrees wins upon the affections, and gains the confidence of the poor madmanwocthes him, cheors him, and performs for him all tender offices of filial love ; and this good Samaritan is of course the heart-stricken, remorseful poet, Molière himself.

There is a love-story interwoven of no great interest, and many discussions between the poet and the madman, on morals, medicine, philosophy : that in which the insane doctor endeavors to prove that many of bis patients who appear to be living are in reality dead, is very striking and very true to nature : shows how ingenious metaphysical madness can cometimes be.

Otber known personages, as Boileau, Chapelain, Racine, are introduced in person, and give us their 
opinions on poetry, acting, the fine arts, with consi derable discrimination, in the characters of the speakers.

The scenes of Parisian society in this novel are not so good; rather heavy and Germanesque-certainly not French.

"Lessing" is another tale in which Sternberg bas takeu a real personage for his hero. Hie says that he has endeavored, in these two tales, to delineate the strife which a man whose genius is in advance of the age in which he lives, must carry on with all around him. They may be called biographical novels.

“ Galathée," Sternberg's last novel, had just made its appearance when I was at Weimar; all the women were reading it and commenting on it-some in anger, some in sorrow, almost all in admiration. It is allowed to be the finest thing he has done in point of style. To me it is a painful book. It is the history of the intrigues of a beautifut coquette and a Jesuit priest to gain over a young Protestant nobleman from his faith and his betrothed love. They prove but too successful. In the end he turn; Roman Catholic, and forsakes his bride. The heroine, Galathèe, dies quietly of a broked heart. "The more fool she!" 1 thought, as I closed the book, "to die for the sake of a man who was not worth living for!" but "'tis a way we have."

Sternberg's women-his virtuous women especially. (to be sure he is rather sparing of them,) have always individual character, and wre touched 
with a firm, a delicate, a graceful pencil; but bis men are almost without exception vile, or insipid, or escentric-and his heroes (where could bo find them I) axe absolutely chararterless-as weak es they are detestable.

Sternberg possesses, with many other talents, that of being an accomplished amateur artist. $\mathrm{He}$ aketches charmingly and with enviable facility and truth catches the characteristic forms both of persons and thinga. Then he has all the arcana of a lady's toilette at the end of his pencil, and his glance is as factidious it is rapid in detecting any peculiarity of dress or manner. Whenever he came to us ho used to ask for some white paper, which, while he talked or listened, he covered with the prettiest aketches and fancies imaginable; but whether this was $t 0$ employ his fingers, or to prevent mo from looking into his ejes while he spoke, I was never guite sure.

This talent for drawing-this lively sense of the pieturesque in form and color, we trace through all his works. Some of the most striking passagesthose which dwell most strongly on the memoryare pictures. Thus the meeting of Molière and the Poctor in the church-yard at dusk of evening, the manifac ceated on the grave, the other standing by. wrapped in his flowing mantle, with his hat and Seather pulled over his brow, and bending over his victim with benevolent expression, is what painters call a fine "bit of effoct." The scene in the halflighted chapel, where the beautiful Countess Melicarte is doing penance, and receiving on her naked 
shoulders the scourge from the hand of her confessor, is a very powerful but also a very disagreeable piece of painting. The lady in crimson velvet seated on the ground en Madelene, with her silver crucifix on her knees and her long dark jewelled tresses flowing dishevelled, is a fine bit of color, and the court ballet in the gardens of the Favorita Falace a perfect Watteau. Reading very fine, eloquent, and vivid descriptions of nature and natural scenery, by writers who give us licentious pietures of nocial life in a narrow, depraved, and sativical spirit, very disagreeable-it always leaves on the mind an impression of discord and unfitness. And this discrepancy is of perpetual recurrence in Sternberg. and in other writers of his class.

But it is in the tale entitled Die Gebruder Breughel (the Two Breughels) that Sternberg has abandoned himself con amore to all his artist-like feetinge and predilections. The younger Bretrghel (known by the names of Hollen Breughel and the "Mad Painter," on accuunt of the diabolical subjects in which his pencil revelled,) is the bero of this romarkable tale : forsaking the worship of beauty, he paid a kind of crazed adoration to deformity, and painted his fantastic and extraragant creations with truly demoniac skill and power. Sternberg makes the cause of this eccentric perversion of genius a love-affair, which has turned the poor painter's wits "the seamy side without," and rendered him the apostate to all that is beautiful in nature and art. This love-tale, however, occupies little of the interest. The charm of the whole consists in the lively 20* 
incebce of Flomist art, and the charecteristic poruniw of diforent well-known artiets : we have the Bey. viracious Tonion-the elegant and somewhat Soctod Poelenberg-the coarse, good-humored Jerdecne-Peter Laors, the tavern-keeper-the gurve yet splendid coxcombry of the Velvet Breughel-his occentric, balf-erazed brother, the Bero-old Petor Kock, with his color mania, (the Turner of hieday, ). and presiding over all, the noble, the sagnificont Poter Paul Rubens, and the dignifod, benovolent Burgomaster Hubert, the patron of art: all theoe are brought together in groups, and chirebly diecriminatod. In this tale, Sternberg hes most ingeniously trabsferred to his pages some celebratod and well-known pictures as actual scenes; and thus Painting pays back part of her debt to Pootry and Fiction. The Alchymist in his laborawry-the Gambling Soldiers-the Boors and Beg. gars at cards-the Incantation in the Witch's Tower the Barning Mill-the Page asleep in the Anteehamber-and the Country Merrymaking - are each - Rombrandt, a Jordaens, an Ostade, a Peter Laers, - Breugbel, or a Teniers, transferred from the canvase to the page, and painted in words almost as brilliant and lively as the original colors.

I doubt whether a translation of this clever talo would please generally in Englend; it is too discarsive and argumentative. It requires a familiar knowledge of art and artists, as well as a feeling for art, to enter into it, for it is almost entirely devoid of any intereat arioing from incident or passion. Yet I sat up till aftor. two. a'clock this morning to. 
finish it, wasting my eyes over the small type, like a most foolish improvident woman.

As the rolling stone gathers no moss, so the roving heart gathers no affections.

I have met with certain minds which seem never to be themselves penetrated by truth, yet have the power to demonstrate clearly and beautifully to other minds, as there are certain substances which most brightly reflect, and only partially absorb, the rays of light.

Reading what Charles Lamb says on the "sanity of true genius," it appears to me that genius and sanity have nothing (necessarily) to do with each other. Genius may be combined with a healthy or a morbid organization. Shakspeare, Walter Scottr Goéthe, are examples of the former: Byron, Collins, Kirke White, are examples of the latter.

A man may be as much a fool from the want of censibility as the want of sense. 
How admirable whet Sir James Mackimtosh says of Madame de Maintenon! - that " she was as vir tuous as the fear of holl and the foar of strame could make her." The same might be said of the virtuv of many women I know, and of these, I boliove that more are virtuous frum the fear of sbame than the fear of bell.-Shame is the woman's bell.

Rabel" said once of an acquaintance, "Such a one is an ignorant man. He knows nothing but what he has learned, and that is little, for a man can only learn that which man already knowrs." - Well, and truly, and profoundly said!

Every faculty, every impulse of our buman nature, is useful, available, in proportion as it is dargerous. The greatest blessings are those which may be perverted to most pain : as fire and water are the two most murderous agents in nature, and the two things in which we can least endure to bo atinted.

Who that has lived in the world, in society, and - looked on both with observing eye, but has often

- Madame Varnhagen von Ense, whose remains were pub. lished a few years ago. The book of "Rahel" is famous from. one end of Germany to the oth sr, but remains, I believe, a sealed fountain still for English readers. 
been astonished at the forrlessness of women, and the cowardice of men, with regard to public opinion? The reverse would seem to be the natural, the necessary result of the existing order of things, but it is not always so. Exceptions occur so often, and so immediately within my own province of observation, that they have made me reflect a gond deal. Perhaps this seeming discrepancy might be thus explained.

Women are brought up in the fear of opinion, but from their ignorance of the world, they are in fact ignorant of that which they fear. They fear opinion as a child fears a spectre, as something shadowy and horrible, not defined or palpable. It is a fear based on habit, on feeling, not on principle or reason. When their passions are strongly excited, or when reasan becomes matured, this exaggerated fear vanishes, and the probability is, that they are immodiately thrown into the opposite extreme of incredulity, defiance and rashness : but a man, even while courage is preached to him, learns from habitual intercourse with the world, the immense, the terrible power of opinion. It wraps him round like despotism; it is a reality to him; to a woman a shadow, and if she can overcome the fear in her own person, all is overcome. A man fears opinion for himself, his wife, bis daughter; and if the fear of opinion be brought into conflict with primary sentiments and principles, it is ten to one but the habit of fear prevails, and opinion triumphs over reason and feeling too, 
Tho new law passed during the last session of our provincial parliament, "to render the remedy in cases of seduction more effectual," has just come into operation. W' hat vere the circumstances which gave rise to this law, and to its peculiar provisions, I cannot loarn. Here it is touching on delicate and even forbidden ground to ask any questions. One person said that it was to guard against iufanticide; and I recullect bearing the same sort of argument used in London against one particular clause of the new Poor Law Act, viz. that it would encourage infanticide. This is the most gross and unpardonable libel on our sex ever uttered. Women do not murder their children from the fear of want, but from the fear of shame. In this fear, substituted for the light and the strength of virtue and genuine self-respect, are women trained, till it becomes a second nature-not indeed tronger than the natural instincts and the passions which God gave us, but strong enough to drive to madness and delirious outrage the wretched victim who finds the struggle between these contradictory foelings too great for her conscience, her reason, her strength. Nothing, as it seems to me, but throwing the woman upon her own self-respect and added responsibility, can bring a remedy to this fearful state of things. To say that the punishment of the fault, already too great, is thereby increased, is not true; it admitted of no real increase. In entailing irremediable disgrace, and death of name and fame, upon the frail woman, the law of society had done its utmost; and to let it be supposed that the man had power to make 
amends by paying a nominal tax for indulgence bought at such a tremendous price, what was it but to flatter and delude both the vanity of lordly, sensual man, and the weakness of wretched, ignorant, trusting woman? As long as treachery to woman is honorable in man; as long as men do not, or will not protect us; as long as we women cannot protect ourselves, their protecting laws are a farce and a mockery. Opinion has ever been stronger than law. Luckily there is something stronger than either.

It was not for the forms, though fair, Though grand they were beyond compare,It was not only for the forms Of hills in sunshine or in storms, Or only unrestrain'd to look On wood and lake, that she forsook

By day or night

Her home, and far Wander'd by light

Of sun or star-

It was to feel her fancy free,

Free in a world without an end: With ears to hear, and eyes to see, And heart to apprehend.

TAYLOR's Philip Van Artevelde.

June 13.

In these latter days I have lived in friendly com. munion with so many exellent people, that my departure from Toronto was not what $I$ anticipated -an escape on one side, or a riddance un the o ther $M y$ projected tour to the west excited not only some interest, but much kind solicitude; and aid 
and counsel were tendered with a feeling which touched mo deeply. The chief justice, in particular, sont me a whole sheet of instructions, and several letters of introduction to settlers along my line of route. Fitzgibbon, always benevolent, gave me consible and cheerful encouragement as we walked loisurely down to the pier, to embark in the steamboet which was to carry me across the lake to Niagara.

And here I might moralize on the good effects of being too early instead of too late on a journey : on the preseut occasion, having a quarter of an hour or twenty minutes to spare proved the most important and most fortunate circumstance which could have occurred at my outset.

The first bell of the steam-boat had not yet rung, when my good friend Dr. Rees came running up to tell me that the missionary from the Sault St.Marie, and his Indian wife, had arrived at Toronto, and were then at the inn, and that there was just time to introduce me to them. No sooner thought than done : in another moment we were in the hotel, and I was introduced to Mrs. Mac Murray, otherwiseO-ge-ne-bu-go-quay, (i. e. the woild rose.)

I must confess that the specimens of Indian equaws and half-cast women I had met with, had in no wise propared me for what I found in Mre. Mac Murray. The first glance, the first sound of ber voice, struck me with a pleased surprise. Her figure is tall-at least it is rather abuve than below the middle size, with that indescribable grace and undulation of movement which speaks the perfection 
of form. Her features are distinctly Ińdian, but softened and refined, and their expression at once bright and kindly. Her dark eyes have a sort of fawn-like shyness in their glance, but. her manner, though timid, was quite free from embarrassment or restraint. She speaks English well, with a slightly foreign intonation, not the less pleasing to my ear that it reminded me of the voice and accent of some of uny German friends. In two minutes I was seated by her-my hand kindly folded in hers-and we were talking over the possibility of my plans. It seems there is some chance of $m y$ reaching the Island of Michillimackinac, but of the Sault St. Marie, I dare hardly think as yet-it looms in my imagination dimly described in far space, a kind of Uhtima Thule; yet the sight of Mrs. MacMurray seemed to give something definite to the rague hope which had been floating in my mind. Her sister. she said, was married to the Indian ágent at Michillimaekinac," a man celebrated in the United States for his scientific researches; and from both she promised me a welcome, should I reach their island. To her own far-off home at the Sault St. Marie, between Lake Huron and Lake Superior, she warmly invited me-without, however, being able to point out any conveyance or mode of travel thither that could be depended on-only a possible chance of such. Meantime, there was some hope of our meeting somewhere on the road, but it was of the faintest. She thanked me feelingly for the interest I

\section{- Kenry Schooleraft, Req.}

VOL: IT. 
took in her own fated race, and gave me excellent hints as to my manner of procesding. We were in the full tide of conversation when the bell of the steam-boat rang for the lant time, and I was hurried off. On the deck of the vessel I found her husband, Mr. MacMurray, who had only time to say, in fewcot worde, all that was proper, polite, and bospitable. This rencontre, which some would call accidental, and some providential, pleased and encouraged me, and I felt very grateful to Dr, Rees.

Then camo blessings, good wishes, kind pressures of the hand, and last adieus, and waving of handkerchiefs from the shore, as the paddles were set in motion, and we glided swiftly over the mirrer-like bay, while "there was not a breath the blue waves to curl."

I bad not been happy enough in Toronto to regret it as a place; and if touched, as I truly was, by the kind solicitude of those friends who, but a few weeks ago, were entire strangers to me, I yet felt no sorrow. Though no longer young, I am quite young enough to feel all the excitement of plunging into scenes so entirely new as were now opening before me; and this, too, with a specific object far beyond mere amusement and excitement-an object not unworthy.

But though the spirit was willing and cheerful, I was under the necessity of remembering that $I$ was not all spirit, but clogged with a material frame which required some looking after. My general health bad suffered during the long trying winter, and it was judiciously suggested that I should spend 
a fortnight at the falls of Niagara to recruit, previous to my journey. The good sense of this advice 1 could not appreciate at the time, any more than I could anticipate the fatigues and difficulties which awaited me; but my good angel, in the shape of a certain languid inclination for silence and repose, whispered me to listen and obey-fortunately, or providentially. Meantime I was alone-aloneand on my way to that ultimate somewhere of which 1 knew nothing, with forests, and plains, and successive seas intervening. The day was sultry, the air heavy and still, and a strange fog, or rather a series of dark clouds, hung resting on the bosom of the lake, which in some places was smooth and transparent as glass-in others, little eddies of wind had ruffled it into tiny waves, or welts rather-so that it presented the appearance of patchwork. The boatmen looked up and foretold a storm; but when we came within three or four miles from the mouth of the river Niagara, the fog drew off like a curtain, and the interminable line of the dark forest came into view, stretching right and left along the whole horizon; then the white buildings of the Ameriean. fort, and the spires of the town of Niagara, became visible against the rich purple-green back-ground and we landed after a four hours' royage. The threatened storm came on that night. The summer storms of Canada are like those of the tropics; not in Italy, not among the Appenines; where I have in ny time heard the "live thunder leaping from crag to erag," did I ever hear sueh terrific explosions of so und as burst over our heads this night. Tho 
silence and the darkness lent an added horror to the elemental tumult - and for the first time in my life I folt sickened and unpleasantly affected in the intervals between the thunder-claps, though I cannot say I folt fear. Meantime the rain fell as in a deluge, threatening to wash us into the lake, which reared itself up, and roared-like monster for its prey.

Yet the next morning, when I went down upon the shore, how beautiful it looked-the hypocrite! -there it lay rocking and sleeping in the sunshine, quiet as a cradled infant. Niagara, in its girdle of verdure and foliage, glowing with fresh life, and breathing perfume, appeared to me a far different place from what I had seen in winter. Yet I recollect, as I stood on the shore, the effect produced on my mind by the sound of the death-bell pealing along the sunny blue waters. They said it was tolled for a young man of respectable family, who, at the age of three or four and twenty, had died from habitual drinking; his elder brotber having a year or two before fallen from his horse in a state of intoxication, and perishod in consequence. Yes, overy thing I see and hear on this subject convinces me that it should be one of the first objects of the government to put down, by all and every means, a vice which is rotting at the core of this infant society-poisoning the very sources of existence. But all their taxes, and prohibitions, and excise laws, will do little gnod, unless they facilitate the means of education. In society the same evening, the appearance of a very young, rery pretty, sad-looking creature, with her first baby at her bosom, whose 
husband was staggering and talking drunken gibberish at her side, completed the impression of disgust and affright with which the continual spectacle of this vile habit strikes me since $I$ have been in this country.

In the dockyard here, I was glad to find all in movement; a steamer was on the stocks, measuring . one hundred and twenty-nine feet in length, and twenty in the beam; also a large schooner; and all the brass-work and casting is now done here, which was formerly executed at Montreal, to the manifest advantage of the province, as well as the town. And I have been assured, not only here but elsewhere, that the work turned out is excellent-of the first order.

In the jail here, a wretched maniac is confined in chains for murdering his wife. He was convicted, condemned to death, and on the point of being hung; for though the physician believed the man mad, he could nat prove it in evidence : he appeared rational on every subject. At length, after his condemnation, the physician, holding his wrist, repeated the religious Orange toast-something about the Pope and the devil ; and instantly, as be expressed it, the man's pulse bounded like a shot under his fingers, and he was seized with a fit of frenzy. He said that his wife had been possessed by the seven deadly sins, and he had merely giren her seven kicks to exorcise her-and thus be murdered the poor woman. He has been in the jail four years, and is now more mad, more furious, than when first confined. This I had from the physician himself. 
Before quitting the subject of Niagara, I may as well mention an incident which occurred shortly afterwards, on my lust visit to the town, which interested me much at the time, and threw the whole of this little community into a wonderful ferment.

A black man, a slave soniewhere in Kentucky, having been sent on a message, mounted on a very valuable borse, seized the opportunity of escaping. He reached Buffalo after many days of hard riding, cold the horse, and escaped beyond the lines into Canada. Here, as in all the British dominions, God be praised ! the stave is slave no more, but free, and protected in his freedom. This man acknowledged that he had not been ill treated; he had received somo education, and had been a favorite with his master. He gave as a reason for his flight, that he had long wished to marry, but was resolved that - his children should not be born slaves. In Canada, a runaway slave is assured of legal protection; but, by an international compact between the United States and our provinces, all felons are mutually surrendered. Against this young man the jury in Kentucky bad found a true bill for horse-stealing; as a folon, therefore, he was pursued, and, on the proper legal requisition, arrested; and then lodged in the jail of Niagara, to be given up to his master, who, with an American constable, was in readiness

- Among the addrenses presented to Sir Francis Head, in 1826, was one from the colored inhabitants of this part of tho province, signed by four hundred and thirty-one individuala, mont of them refugees from the United States, or their descendants. 
to take him into custody, as soon as the government order sbould arrive. His case excited a strong. interest among the whites, while the colored populalation. consisting of many hundreds in the districts of Gore and Niagara, chiefly refugees from the States, were half frantic with excitement. They loudly and openly declared that they would peril their lives to prevent bis being carried again across the frontiers, and surrendered to the rengeance of his angry master. Meantime there was some delay about legal forms, and the mayor and several of the inhabitants of the town, united in a petition to the governor in his favor. In this petition it was expressly mentioned that the master of the slave had - been heard to avow that his intention was not to give the culprit up to justice, but to make what be called an example of him. Now there had been lately some frightful instances of what the slave proprietors of the south called "making an example ;" and the petitioners entreated the governor to interpose, and save the man from a torturing death " under the lash or at the stake." Probably the governor's own bumane feelings pleaded even more strongly in behalf of the poor fellow. But it was a case in which he could not act from feeling, or, " to du a great right, do a little wrong." The low was too expressly and distinctly laid down, and his duty as governor was clear and imperativo-to give up the felon, although, to have protected the slave, he would, if necessary, bave armed the province.

In the moan time the colored people assembled 
from the adjacent villages, and among them a great number of their women. The conduct of this black mob, animated and even directed by the females, was really admirable for its good sense, forbearance, and resolution. They were quite unarmed, and declared their intention not to commit any violence. against the English law. The culprit, they said, might lie in the jail, till they could raise among them the price of the horse; but if any attempt were made to take him from the prison, and send him aross to Lewriston, they would resist it at the bazard of their lives.

The fatal order did at length come; the sheriff with a party of constables prepared to enforce it. The blacks, still unarmed, assembled round the jail, and waited till their comrade, or their brother as they ealled him, was brought out and placed handcuffed in a cart. They then threw themselves simultaneously on the sheriff's party, and a dreadful scuffle ensued; the artillery men from the little fort, our only military, were called in aid of the civil authority, and ordered to fire, on the assailants. Two blacks were killod, and two or three wounded. In the melée the poor slave escaped, and has not since been retaken, neither was he, I believe, pursued.

But it was the conduct of the women which, or this occasion, excited the strongest surprise and interest. By all those passionate and persuasive arguments that a woman knows so well how to use, whatever be her color, country, or class, they had prevailed on their husbands, brothers, and lovers, to use no arms, to do no illegal violence, but to lose 
their lives rather than see their comrade taken by force across the lines. They had been most active in the fray, throwing themselves fearlessly between the black men and the whites, who, of course, shrank from injuring them. One woman had seized tho sheriff, and held him pinioned in ber arms ; another, on one of the artillery-men presenting his piece, and swearing that he would shoot her if she did not get out of his way, gave him only one glance of unutterable contempt, and with one hand knocking up his piece, and collaring him with the other, held him in such a manner as to prevent his firing. I was curious to see a mulatto woman who had been foremost in the fray, and whose intelligence and influence had mainly contributed to the success of her people; and young Mr. M-, under pretence of inquiring after a sick child, drove me round to the hovel in which she lived, outside the town. She came out to speak to us. She was a fine creature, apparently about five-and-twenty, withakindly animated countenance; but the feelings of exasperation and indignation had ovidently not yet subsided. She told us, in answer to my close questioning, that she had formerly been. a slave in Virginia ; that, so far from being ill-treated, she bad been regarded with especial kindness by the family on whose estate she was born. When she was about sixteen her master died, and it was said that all the slaves ori the estate would be sold, and therefore she ran away. "Were you not attached to your mistress ?" I asked. "Yes," said she, "I liked my mistress, but I did not like to be cold." I asked ber if she was happy here in Canada? 
She hesitated a moment, and then replied, on my repeating the question, "Yes-that is, I was happy here-but now-I don't know-I thought we were safe here-I thought nothing could touch us here, on your British ground, but it seems I was mistaken, and if so I won't stay here-I won't-I won't! I'll go and find some country where they cannot reach us ! l'll go to the end of the world, I will !" And as she spoke, her black eyes flashing, she extended her arms, and folded them across her bosom, with an attitude and expression of resolute dignity, which a painter might bave studied; and truly the fairest white face I ever looked on never beamed with more of soul and high resolve than hers at that moment. 
BeTween the town of Queenston and the cataract of Niagara lies the pretty village of Stamford, (close to Lundy Lane, the site of a famous battle in the last war,) and celebrated for its fine air. Near it is a beautiful house with its domain, called Stamford Park, built and laid out by a former governor (Sir Peregrine Maitland.) It is the only place I saw in Upper Canada combining our ideas of an elegant, well-furnished English villa and ornamented grounds, with some of the grandest and wildest features of the forest scene. It enchanted me altogether. From the lawn before the house, an open glade, commanding a park-like range of broken and undulating ground and wooded valleys, displayed beyond them the wide expanse of Lake Ontario, even the Toronto light-house, at a distance of thirty miles, being frequently visible to the naked eye. By the hostess of this charming seat I was conveyed in a light pony carriage to the botel at the Falls, and left, with real kindness, to follow my own devices. The moment I was alone, I hurried down to the Tablerock. The body of water was more full and tre. mendous than in the winter. The spray rose, densely falling again in thick showers, and behind those rolling volumes of vapor the last gleams of the evening light shone in lurid brightness, amid amber and crimson clouds; on the other side, night was rapidly coming on; and all was black, impenetrable 
gloom, and "boundless contiguity of shade." It was rery, very beautiful, and strangely awful too! For now it was late, and as I stood there, lost in a thousand reveries, there was no human being near, no light but that reflected from the leaping, whirling foam; and in spite of the deep-voiced continuous thunder of the cataract, there was such a stillness that I could hear my own heart's pulse thrubor did I mistake feeling for hearing ? - so I strayed bomewards, or housewards I should say, through the leafy, gloomy, pathways - wet with the spray and fairly tired out.

Two or three of $\mathrm{my}$ Toronto friends are here, and declare against my projects of solitude. To-day we had a beautiful drive to Colonel Delatre's. We drove along the road above the Falls. There was the wide river spreading like a vast lake, then narrowing, then boiling, foaming along in a current of eighteen miles-an hour, till it swept over the Crescent rock in a sheet of emerald green, and threw up the silver clouds of spray into the clear blue sky. The fresh luxurious verdure of the woods, relieved against the dark pine forest, added to the beauty of scene. I wished more than ever for those I love most - for some one who would share all this rap. ture of admiration and delight, without the necessity of speaking - for after all, what are words? They express notbing, reveal nothing, avail nothing. So it all sinks back into my own heart, there to be kept 
quiet. After a pleasant dinner and music, I returaed to the hotel by the light of a full moon, beneath which the Falls looked magnificently mysterious, part glancing silver light, and part dark shadow, mingled with fleecy folds of spray, over which floated a soft, sleepy gleam; and in the midst of this tremendous velocity of motion and eternity of sound, there was a deep, deep repose, as in a dream. It impressed me for the time like something supernatural-a vision, not a reality.

The good people, travellers, describers, poets, and others, who seem to bave bunted through the dictionary for words in which to depict these cataracts under every aspect, have never said enough of the rapida above- even for which reason, perbaps, they have struck me the more; not that any words in any language would have prepared me for what I now feel in this wondrous scene. Standing to-day on the banks above the Crescent Fall near Mr. Streetis mill, gazing on the rapids, they left in my fancy two impressions which seldom meet together-that of the sublime and terrible, and that of the elegant and greceful-like a tiger at play. I could not withdray my eyes; it was like a fascination.

The verge of the rapids is considerably above the eye; the whole mighty river comes rushing over the brow of a hill, and as you look up, it seems coming down to overwhelm you. 'Then meeting with the rocks, as it pours down the declivity, it boils and voL. 1 . 
frots like the breakers of the ocean. Huge mounds of water, smooth, transparent and gleaming like the emerald, or rather like the more delicate hue of the chrysopaz, rise up and bound over some unseen impediment, then break into silver foam, which leaps into the air in the most graceful fantastic forms; and so it rusbes on, whirling, boiling, dancing, sparkling along, with a playful impatience, rather than overwhelming fury, rejoicing as if escaped from bondage, rather than raging in angry might-wildly, magnificently beautiful! The idea, too, of the immediate danger, the consciousness that any thing caught within its verge is inevitably burried to a swift destination, swallowed up, aunibilated, thrills the blood; the immensity of the picture, spreading a mile at least each way, and framed in by the interminable forests, adds to the feeling of grandeur: while the giddy, infinite motion of the beadlong wators, dancing and loaping, and revelling and roaring, in their mad glee, gave me a sensation of rapturous terror, and at last caused a tension of the nerves in my head, which obliged me to turn away.

The great ocean, when thus agitated by conflict. ing winds or opposing rocks, is a more tremendous thing, but it is merely tremendous-it makes us think of our prayers; whereas, while I was looking on these rapids, beauty and terror, power and joy, were blended, and so thoroughly, that oven while I trembled and admired, I could hare burst into a wild laugh, and joined the dancing billows in their glorious, fearful mirth- 
Leaping like Bacchanals from rock to rock, Flinging the frantic Thyrsus wild and high!

I shall never see again, or feel again, aught like it-never! I did not think there was an object in nature, animate or inanimate, that could thus overset me novo! 
I uArE only tbree boaks with mo here, besides the ome bonk needful, and find them sufficient for all purposes-Shakspeare, Schiller, Wordsworth. One morning, being utterly disinclined for all effort, oither of conversation or movement, 1 wandered down 20 a little wild bosquet beyond the Tablerock, not rery accessible to dilettante hunters after the picturesque, and just where the waters, rebdered smooth by their own infinite velocity, were srreeping by, before they take their leap into the gulf below; - there I sat all the sultry noontidequiet, among the birds and the thick foliage, and road through Don Carlos-one of the finest dramas in the world, I should think.

It is a proof of the profound humanity of Schiller, that in this play one must needs pity King Philip, though it is in truth the sort of pity which Saint Theresa felt for the devil -one pities bim because be is the devil. The pitiableness and the misery of wickedness were never so truly and so pathetically demonstrated. The unfathomable abyss of egotism in the character turns one giddy to look inta.

With regard to Posa, it has been objected, I bolieve-for 1 never read any criticism on this playthat he is a mere abstraction, or rather the embodied mouthpiece of certain abstract ideas of policy and religion and morals-those of Schiller himself-and not an individual human being-in short, an impossi- 
bility. Yet, why so? Perhaps such a man as Posa never did exist;-but why impossible ? Can a man conceive that which a man could not by possibility be? If Schiller were great enough to invent such a character, is not humanity great enough to realize it? My belief is, that it is only a glorious anticipation - that poets in some sort are the prophets of perfection-that Schiller himself might bave been a Posa, and, had he lived a century or two hence, would have been a Posa. Is that a mere abstrace tion which while I read, makes me thrill, tremble, exult, and burn, and on the stage filled my eyes with most delicious tears? Is that a mere abstrao tion which, excites our human sympathies in the strongest, highest degree? Every woman, methinks, would like a Posa for a lover-at least, if I could love, it would be such a man. The notion that Posa could not by possibility exist in the court of Philip II. appears to me unfounded, for such a court would be just the place where such a character would be needed, and by reaction produced : extremes meet. Has not the Austrian court in these days, produced Count Auersperg, the poet of freedom, who has devoted his whole soul, his genius, and his gift of song, to the cause of humanity and liberty? Francis the First and Metternich, and the dungeons of the Spielberg, have as naturally produced an Auersperg, as Pbilip and the Autos-da-Fo in Flanders might have produced a Posa.

It may be said that the moral unity and consistency of the character of Posa is violated by that lie which he tells to save the life of Carles. 
Pose is living in an atmosphere of falsehood; the exiatence and honor of Carips are about to be sacrificed by a lie, and Posa, by another lie, draws the rengeance of the king upon himself;

Magnanima menzozna! or quando è il varo Si bello, che si possa a te preporre?

-But the effect of this "magnanimous" falsehood is like that of all falsohood, evil. This one deviation from the clear straight line of truth not only fails of its purpose, but plunges Carlos, the queen, and Posa himself, in the same abyse of destruction.

It was the opinion of $\longrightarrow$, witb whom I read this play in Germany, that the queen (Elizabeth of France, Philip's second wife) is a character not defined, nat easily understood-that there is a mystery about her intended by the author. I do not see the character in this point of view. It does not coem to me that Schiller meant her to be any thing but what she appears. There is no mask here, conscious or unconscious; in such a mind her love for Don Carlos is not a feeling combated, struggled with, but put out of her mind altogether, as a thing which ought not to be thought of, ought not to exint, and therefore ceases to exist; - a tender, perfoctly pure interest in the happiness and the fate of Don Carlos remains; but this is all; she does not cheat herself nor us with verbal virtue. The cloudless, transparent, crystalline purity of the character is its greatest charm, it will be said perhaps, that if we see the whole -if there be indeed nothing veiled, beyond or beneath what is visible and spoken, then it is shallow. Not so-but, like perfectly limpid 
water, it seems shallower than it is. The mind of a woman, which should be wholly pure, simple, and true, would produce this illusion: we see at once to the bottom, whether it be shining pebble or golden sands, and do not perceive the true depth till we try, and are made to feel and know it by getting beyond our own depth before we are aware. Such a character is that of Elizabeth of France. The manner in which she rebukes the passionate ravings of Carlos-the self-confiding simplicity-the dignity without assumption-the virtue, so clothed in innocence as to be almost unconscious - all is most beautiful, and would certainly lose its charm the momènt we doubted its truth-the moment we suspected that the queen was acting a forced or a conscious part, however virtuous. The scene in whicb Elizabeth repels the temptation of the Duke of Alva and the monk might be well contrasted with the similar scene between Catherine of Arragon and the two cardinals in Shakspeare. Elizabeth has a passive, graceful, uncontending pride of virtue, which does not assert itself, only guards itself. Her genuine admiration of Posa, and the manner in which, in the last scene, you see the whole soft, feminine being, made up of affections, tears, and devotion, develope itself to. be caught and crushed as in an iron vice, renders this delineation, delicate as it is in the conception, and subordinate in interest, one of the finest $I$ have met with out of Shakspeare, and comparable only to his Hermione in the beauty and singleness of the conception.

When I saw Don Carlos. performed at Viennaw 
with a perfoction and ensemble of which our stage afurds few examples, it left, as a work of art, an impression of a moral kind, at once delightful and elevating. which I cennot easily forget. I was never more touched, more excited, by any dramatic representation that I can remember. Korn, allowed to be one of their finest actors, played Posa maguificently; and it seemed to be no slight privilege totread the stage but for three hours, clothed in such god-like attributes - to utter, in words eloquent as music, the sentiments of a maN-sentiments and I spirations that, in every thrilling heart, found at loast a silont echo-sentiments which, if uttered or written off the stage, would have brought down upon him the surveillance of the secret police, or the ben of the censor.

Fichtner played Don Carlos with impassioned youthful sensibility; and though I beard it objected by the Princess $\mathrm{H} \longrightarrow$, that he had not suffeiently l'air noble, it did not strike me. Karl La Roche, an actor formed under Goêthe's tuition, in the gulden age of the Woimar theatre, played Philip II., and looked, and dressed, and acted the character with terrible and artist-like fidelity. Mademoiselle Fournier, one of the most beautiful women I ever beheld, and a clever actress, was admirable in the Princess Eboli. Mademoiselle Peche, also a good actress, failed in the queen, as at the time I felt rather than thought, for $I$ had not well considered the character. She embodied too formally, perhaps intentionally, the idea of something repressed and concealed with effort, which I do not find in 
Schiller's Elizabeth. On this representation occurred an incident worth noting. The old Emperor Francis was present in his box, looking, as usual, rery heavy-headed and attentive; it was about a montb or six weeks before his death. In the scene where Posa expostulates with King Philip, pleads eloquently for toleration and liberty, and at length, throwing himself at his feet, exclaims, "Geben Sie uns Gedankenfreiheit!" the audience, that is, the parterre, applauded; and there were around me, cries, not loud but deep, of " Bravo, Schiller!" After this the performance of Don Carlos was forbidden, and it was not given again while I was at Vienna.

This I write: for your edification before I go to rest, after a day of much quiet enjoyment and luxurious indolence. The orb of the moon now risen is now suspended upou the very verge of the American, fall; just opposite to my balcony; the foam of the rapids shines beneath ber in dazzling, shifting, fantastic figures of frosted silver, while the downward perpendicular leap of the waters is almost lost to view-all mysterious tumult and shadow.

Accompanied the family of Colonel Delatre to the American side, and dined on Goat Island. Though the various views of the two cataracts be here wonderfully grand and beautiful, and the bridge across the rapids a sort of miracle, as they 
any, still it is not altogether to be compared to the Canadian shore for picturesque scenery. The Americans have disfigured their share of the rapids with mills and manufactories, and horrid red brick houses, and other unacceptable, unseasonable sights and signe of sordid industry. Worse than all is the round tower, which some profane wretch has erected ou the Crescent Fall ; it stands there so detestably impudent and mal-d-propos-it is such a signal yet puny monument of bad taste - so miserably mesquin, and so presumptuous, that I do hope the violated majesty of nature will take the matter in hand, and overwhelm or cast it down the precipice one of these fine days, though indeed a barrel of gunpowder were a shorter if not a surer metbod. Can yous not send us out some Guy Faux, heroically ready to be victimized in the great cause of insulted pature, and no less insulted art ?-But not to tire you with descriptions of precipices, cares, rocks, woods, and rushing waters, which I can buy here ready made fur sixpence, I will only tell you that our party was very pleasant.

Colonel Delatre is a veteran officer, who has purchased a fine lot of land in the neighborhood, has settled on it with a very interesting family, and is cultivating it with great enthusiasm and success. He served for twenty years in India, chiefly in the island of Ceylon, and was present at the capture of that amiable despot, the king of Candy - he who had such a penchant for pounding his suhjects in a mortar. He gave me some anecdotes of this savage war, and of Oriontal life, which were very 
amusing. After answering some questions relative to the condition of the European women in Ceylon, and the unanners and morals of the native women, Colonel Delatre said, with unaffected warmth, "I have seen much hard service in different climates, much of human nature in savage and civilized life, in the east and in the west, and all I have seen has raised your sex generally in my estimation. It is no idle compliment-I speak from my heart. I have the very highest idea of the worth and capabilities of women, founded on experience, but, I must say, the highest pity ton! You are all in a false position; in Englaud, in Ceylon, in America - every where I have found women alike in essentials, and alike ill treated, in one way or in another!"

The people who have spoken or written of these Falls of Niagara, bave surely never dome justice to their loveliness, their inexpressible, inconceivable beauty. The feeling of their beauty has become with me a deeper feeling than that of their sublimity. What a scene this evening! What splendor of color! The emerald and chrysopaz of the transparent waters, the dazzling gleam of the foam, and the snow-white vapor on which was displayed the most perfect and gigantic iris I ever beheldforming not a half, but at least two-thirds of an entire circle, one extremity resting on the lesser (or American) Fall, the other in the very lap of the Crescent Fall, spanning perhaps half a mile, perfectly resplendent in bue-so gorgeous, so virid, and yet so ethereally delicate, and apparently with- 
in a few feet of the eye; the vapore rising into the blue beavens at least four hundred feet, three times the height of the Falls, and tinted rose and amber with the evening sun; and over tho .uroods avound overy possible variety of the richest foliage-ne, nothing was ever oo transendently lovely! Tho effect, too, was so grandly uniform in its eternal sound and movement, it was quite different from that of those wild, impatient, tumultuous rapids. It soothed, it melted, it composed, rather than excited.

There are no water-fowl now as in the winterwhen driven from the ice-bound shores and shallows of the lake, they came up here to soek their food, and sported and wheeled amid the showers of spray. They have returned to their old quiet haunts; sometimes I miss them : they were a beautiful variety in the picture.

How I wish for those I love to enjoy all this with me! I am not enough in myself to feel it all. I cannet suffice for it all, without some sympathy to carry off this "superflu d'ame et de vie ;" it. overwhelms, it pains me. Why should I not go down nowo to the Table-rock or to the rivor's brink below the Falls-now when all is still and salitary, and the rich moonlight is blending heaven and earth, and the rapors, and woods, and waters, in shadowy splendor? All else in nature sleeps-all but those ever-bounding and rejoicing waters, still holding on their-way, ceaseless, exbaustless, without pause or rest. I look out with longing and wakeful eye, but it is midnight, and I am alone; and if I do not 
foel fear, I feel at least the want of a supporting arm, the want of a sustaining heart. So to bed, to be hushod to slumber by that tremendous lullaby.

\section{A D REA M.}

Very significant, poetical, allegorical dreams have often been invented or dreamt with open eyes; bat once I had a singular dream, which was a real dream of sleep-esuch a one as, if I had lived in the days of Pharaoh or Nebuchadnezzar, I should have sent for the nearest magician or prophet to interpret. I remember no vision of the night which ever left on my waking fancy so strong, so vivid an impression; but unfortunately the beginning and the end of the vision faded before I could collect the whole in my remembrance.

I had been reading over, late in the evening, Sternberg's Herr von Mondshein, and in sleep the impression continued. I dreamed I was reading a volume of German tales, and as I read, it seemed as if, by a strange, dream-like, double power of perception, not only the words before me, but the forms and feelings they expressed, became visible and palpable to sense. What I read seemed to act itself before my eyes. It was a long history, full of fantastic shapes and perplexing changes, and things that seemed and were not; but, finally, one image predominated and dwelt on my memory clearly and distinctly, even long after I waked. It was that of a Being, I know not of what nature or sex, whioh จOL. I. 23 
went up and down upon our world lamenting - for it loved all things, suffored with all things, sympathized with all things ; and a crowd of all sentient creatures followed-mon, women, and children, and animalsa mournful throng.

And the Being I have mentioned looked round upon them, and feeling in itself all their miseries, deaires, and wante, wept and wrung its bands.

And at length a wish arose in the heart of that Boing to escape from the sight of surrow and suffering which it could share and not alleviate; and with this wish it looked up for a moment towards heaven, and a cup was beld forth by a heavenly hand-a charmed cup, by which the secret wish was fulfilled, and the Being drank of this cup.

And then, I know not how, all thinge changed. And I saw the same Being standing upon a high altar, in an illuminated temple. The garments were floating in light. The arms were extended towards heaven; the eyes ever upwards turned; but there was no hope or rapture in those eyes; on the contrary, they were melancholy, and swimming in tears. And around the altar was the same crowd of all human and sentient beings, and they looked up constantly with clasped hands, and with a sad and anxious gaze, imploring one of those looks of sympathy and tenderness to which they had been accustomed-but in vain.

And I looked into the heart of that Being which stocd alone upon the altar, and it was also sad, and full of regret and love towards the earth, and vain longing to loak down once more on those creatures: 
but the consecrating spell was too strong; the eyes remained ever directed towards heaven, and the arms were extended upwards; and the bond which had united the sympathizing with the suffering heart was broken for ever.

I do not mean to tell you that I dreamed all this to the sound of the Falls of Niagara ; but I do aver that it was a real bona fide dream. Send me now the interpretation thereof-or look to be sphinx-devoured.

June 18.

Returned from Stamford Park, where I spent a few days rather agreeably, for there were books, music and mirth within, though a perpetual storm raged without.

The distance from the Falls is four miles, and the hollow roar of the cataract not only sounded all night in my ears, but violently shook doors and windows. The very walls seemed to vibrate to the sound.

I came back to the Clifton Hotel, to find my beautiful Falls quite spoiled and discolored. Instead of the soft aquamarine hue, relieved with purest white, a dull dirty brown now imbued the waters. This is owing to the shallowness of Lake Erie, where every storm turns up the muddy bed from the bottom, and discolors the whole river. The spray, instead of 
hovering in light clouds round and above the catarecte, was beaten down, and rolled in volumes round their base; then by the gusty winds driven along the surface of the river hither and thither, covering every thing in the neighborhood with a emall rain. I sat down to draw, and in a moment the paper was wet through. It is as if all had been metamorphosed during my absence-and I feel very disconsolate.

There are, certainly, two ways of contemplating the sublime and beautiful. I remember one day, as I was standing on the Table-rock, feeling very poetical, an Irishman belind me suddenly oxclaimed, in a most cordial brogue, and an accent of genuima admiration- "Faith, then, that's a pretty dacem dhrop o' water that's coming over there!" 
Jane 19.

Trat you may have some understending of $\mathrm{my}$ whereabouts, my outgoings, and my incomings, I intend this to be a chapter on localities; and putting poetry and description far from me, I now writx you a common sensible lecture on topography ane geography. It is no unpardonable offence, I hope, to suppose you as ignorant as I was myself, till I came here.

Perhaps even for my sake you may now and then look upon a map of Canada, and there, as in the maps of Russia in Catharine the Second's time, you will find not a few towns and cities laid down by name which you might in vain look for within the precincts of the province, seeing that they are mon-extant, as yet, at least, though full surely to be, some time or other, somewhere or other, when this fair country shall have fair play, and its fair quota of population. But from this anticipation I would willingly except a certain City or THE Fazls which I have seen marked on so many maps, and mentioned in so many books, as already laid out and com. menced, that I had no doubt of its existence till I came here for the first time last winter. But here it is not-Grazie a Dio! - nor likely to be, wo far as I can judga, for a century to come. Were a city to rise here, it would necessarily become a manufacturing place, because of the " water powers and privi- 
logea," bolow and above the cataract, which would then be tarned to account. Fancy, if you can, a range of cotton factories, iron foundries, grist mills, eaw mills, where now the mighty waters rush along in glee and liberty - where the maple and the pine woode now bend and wave along the heights. SureIf they have done enough already with their wooden hotels, museums, and curiosity stalls: neither in ench a case were red brick tenements, gas-lights, and amoky chimneys, the worst abomination to be seared. There would be a moral pollution brought bro this majestic scene, far more degrading; more than all those rushing waters, with their " thirteen millions of tons per minute," could wash away.

Lot us pray against such a desecration. In the mean time can you tell me who was the first white man whose eyes beheld this wonder of the earth? Ho was a Frenchman, but nowhere do I find record of his name, nor of the impressions which such 8 cecovery would make on any, oven the most valgar and ineensible nature.

In former seasons, the two botels bave been foll to overflowing. They tell me here that last oummer one handred and fifty persons sat down stmost daily to dinner; the far greater number wore travellers and visiters from the United Stetos. This year, owing to the commercial embarrassments of that country, there are so few visiters, that one botel (Fonsyth's) is closed, and the other (Clifton Fouse) is nearly empty, to the serious loss, I foer, of the poor people, but to myself individually en 
unspeakable comfort-for thus I wander about and drive about in full liberty and loneliness.

The whole of this district between the two great lakes is superlatively beautiful, and was the first settled district in Upper Canadi ; it is now the b ist cultivated. The population is larger in proportion to its extent than that of any ofher district. In Niagara, and in the neighboring district of Gore, many fruits come to perfection, which are not found to thrive in other parts of the province, and cargoes of fruit are sent yearly to the cities of Lower Canada, where the climate is much more severe and the winter longer than with us.

On the other side the country is far less beautiful and they say lese fertile, but rich in activity and in population; and thêre are within he same space at least half a dozen flourishing towns. Our speculating energetic Yankee neighbors, not satisfied with their Manchester, thoir manufactories, and their furnaces, and their mill "privileges," have opened a railroad from Lewiston to Puff lo, thus connecting Lake Erie with the Erie Canal. On our side, we have the Welland Canal, a magnificent work, of which the province is justly proud; it unite Lake Erie with Lake Ontario.

Yet from the Falls all along the shores of the Lake Erie to the Grand River and far beyond it, the only place we have approaching to a town is Chippewa, just above the rapids, as yet a small village, but lying immediately in the ruad from the Western States to the Falls. From Buffalo to this place the Americans run a steamboat daily; they 
hare aleo planned a suepension bridge across the Niagara river, between Lewiston and Queenston. Another village, Dunnrille, on the Grand River, is likely to be the commercial depot of that part of the province; it is situated where the Welland Canal joins Lake Erie.

As the woather continued damp and gloomy, witbout bope of change, a sudden whim seized me to go to Buffalo for a day or two; so I crossed the turbulent ferry to Manchester, and thence an engine, snorting, shrieking like fifty tortured animals, conveyed us to Tonawando," once a little village of Seneca Indians, now rising into a town of some sizo and importance; and there to my great delight I encountered once more my new friends, Mr. and Mrs. MacMurray, who were on their return from Toronto to the Sault St. Marie. We proceeded on to Buffalo together, and during the rest of the day had some pleasent opportunities of improving our acquaintanco.

Bufialo, as all travel-books will tell you, is a very fine young city, about ten years old, and containing already about twenty thousand inhabitants. There is here the largoet and most splendid hotel I have orer seen, except at Frankfort. Long rows of magnificent houses-not of painted wood, but of brick and stone-are rising on every side.

The season is unusually dull and dead, and I hear

- Near this place lived and died the chief Red-jacket, one of the lant and grealest specimens of the Indian patriot and warrior, 
nothing but complaints around me; but compared to our sleepy Canadian shore, where a lethargic spell seems to bind up the energies of the people, all here is bustle, animation, activity. In the port I counted about fifty vessels, sloops, schooners, and stesm-boats ; the crowds of people buying, selling, talking, bawling; the Indians lounging by in their blankets, the men looking so dark, and indifferent, and lazy; the women so busy, care-worn, and eager; and the quantities of sturdy children, squalling, frisking among the feet of busy sailors-formed altogether a strange and amusing scene.

On board the Michigan steamer, then lying ready for her voyage up the lakes to Chicago, I found all the arrangements magnificent to a degree I could mot have anticipated. This is one of the three great steam-boats navigating the Upper Lakes, which are from five to seven hundred tons burthen, and there are nearly forty smaller ones coasting Lake Erie, between Buffalo and Detroit, besides schooners. We have (in 1837) on this lake two little ill-constructed steamers, which go puffing up and down like two little tea-kettles, in proportion to the gigantic American boats ; and unfortunately, till our side of the lake is better peopled and eultivated, we have no want of them. When they are required, they will exist as on Lake Ontario, where we have, I believe, eight or ten steamers.

I found here several good booksellers' shops, the counters and shelves loaded with cheap American oditions of English publications, generally of a 
trashy kind, but some good ones; and it is not a pleasing fact that our two booksellers at Toronto aro principally supplied from this place. When I wanted a book at Toronto which was not forthcoming, the ususl answer was, " that it would be sent for from Buffalo." The clothing and millinery shops were the best and gayest in appearance. In the window of one of the largest of these I saw written up in large letten, "Walk in, and name your prico!" Orer the door of another was inscribed, "Book and bandbox store." I marvelled what could bring these apparently beterogeneous articles iuto sucb close emulation and juxtaposition, till I romembered-that both are made of paper.

The MacMurrays, with their beautiful infant and his Indian nurse, embarked on board the Michigan, and I parted from them with regret, for Mrs. MacMurray had won upon me more and more with her soft roice and her benign eyes, and her maternal anxieties.

I was now again alone, in a vast inn, swarming with dirty, lazy, smoking men-the rain was falling in a deluge, and no books-no companions. As I walked disconsolately up and down a great room, they call in American hotels the ladies' parlor, a young girl, very pretty and well dressed, who was swinging herself in a rocking-chair, and reading Mrs. Hemans, rose from her seat, left the room without saying a word, and returned with a handful of books, and several numbers of an excellont literary periodical, "The Knickerbocker, of NewYork." which she most courteously placed before 
me. A cup of water in a desert could hardly have been more welcome, or excited warmer thanks and gratitude. Thus charitably furnished with amusement, the gloomy wet morning did at last glide away, for time and the bour will creep through the dullest, as they " run through" the roughest day. In the evening I went to the theatre, to a private box, a luxury which $I$ had not expected to find in this most democratical of cities. The theatre is small of course, but very neat and prettily decorated. They had an actress frum New-York starring it here for a few nights, the tallest, handsomest woman I ever saw on the stage, who looked over the head of her diminutive Romeo, or down upon him-the said Romeo being dressed in the costume of Othello, turban and all. When in the balcony, the rail did not reach up to Juliet's knees, and I was in perpetual horror lest she should topple down headlong. This would have been the more fatal, as she was the only one who knew any thing of her part. The other actors and actresses favored us with a sort of gabble, in which not only Shakspeare, but numbers, sense, and grammar, were equally put to confusion. Mercutio was an enormously corpulent man with a red nose, who swaggered about and filled up every hiatus of memory with a good round oath. The whole exhibition was so inexpressibly ludicrous, that I was forced to give way to fits of uncontrollable laughter-whereat my companions looked not well pleased. Nor was the audience less amusing than the dramatis personæ: the pit was filled by artisans of the lowest grade, and lake mariners 
sitting in their strew hate and ohirt-sleeves-for fet hed oithor conts or waistcoats. They were most deroutly attentire to the story in their own way, oating cakos and drinking whiokey between the acts, and whenerer any thing espocially pleased them, thoy uttered a loud whoop and balloo, which rever berated through the theatre, at the same time slaps ping thoir thighe and onapping their fingers. In their eyes, Peter and the nurse were evidently the hero and beroine of the piece, and never appeared without calling forth the most boisterous applause. The actor and actress had enriched the humor of Shakspeare by adding several Yankee witticisms and allusions, the exact import of which I could not comprehend; but they gave unqualified delight to the merry parterre. I did not wait for the second entertainment, having some fear that as the tragedy hed proved a farce, the farce might prove a tragedy.

The next morning I returned to the Falls, which are still sullen and turbid, owing to the stormy weather on Lake Erie. 


\section{How divine}

The liberty for frail, for mortal man

To roam at large among unpeopl'd glens;

And mountainous retirements, only trod

By devious footsteps - regions consecrate

To oldest time!

WORDsWORTE.

June 27.

Iv a strange country, much is to be learned by travelling in the public carriages : in Germany and elsewhere I have preferred this mode of conveyance, even when the alternative lay within $\mathrm{my}$ choice, and I never had reason to regret it.

The Canadian stage-coaches* are like those of the United States, heavy, lumbering vehicles, well calculated to live in roads where any decent carriage must needs founder. In one of these I embarked to return to the town of Niagara, thence to pursue my journey westward : a much easier and shorter course had been by the lake steamers; but $\mathrm{my}$ object was not haste, nor to see merely sky and water, but to see the country.

- That is, the better class of them. In some parts of Upper Canada, the stage-coaches conveying the mail were large, oblong wooden boxes, formed of a fow planks nailed together and placed on wheels, into which you entered by the windows, there being no doors to open and shut, and no springs. Two or three seats were suspended inside on leather straps. 'I'he travellers provided their own buffalo-ekins or cushions to sit on.

roL. 1. 
In the stage-cisacb two persons were already seatod'-an English emigrant and bis wife, with whom 1 quickly made ocquaintance after my unal fashion: The circumstances and thestory of this man I thought worth noting - not because there was any thing uncommon or peculiarly interesting in his case, bue simply because his case is that of so many otbers: while the direct good sense, tronesty and iutelligence of the man pleased me exceedingly.

He told wo that he had come to America in his. own behalf and that of several others of his own class - men who bad each a large family and a small capital, who found it difficult to get on and settle their children in England. In his own case, be had been some years ago the only one of his trade in a flourishing country town, where he had now fourtoen competitors. Six families, in a similar positíon, had delegated him on a royage of discovery : it was Teft to him to decide whether they should settle in the United States or in the Canadas; Bo leaving his children at school in Long IsTand, "he was just," to use his own phrase, "taking a tura through the two countries, to look about him and gather information before he decided, and had brought his little wife to sec the grand Falls of Niagara, of which be had heard so much in the old country."

As we proceeded, my companion mingled with his acute questions, and his learned calculations on crops and prices of land, certain observations on the beauty of the scenery, and talked of lights and hades, and foregrounds, and effects, in very homely, 
Plebeian English, but with so much of real taste and feeling, that I was rather astonished, till I found he had been a print-seller and frame-maker, which lant branch of trade had brought him into contact with artists and amateurs; and be told me, with no littlo exultation, that among his stock of moveables, be had brought out with him several fine drawings of Prout, Hunt, and even Turner, acquired in his busimess. He said he had no wish at present to pare with these, for it was his intention, wherever he setaled, to hang them up in his heuse, though that house were a $\log$ hut, that his children might have the pleasure of looking at them, and learn to distinguish what is excellent in its kind.

The next day, on going from Niagara to Hamitwon, in a storm of rain, I found, to my no small gratification, the English emigrant and bis quiet, silent little wife, already seated in the stage, and $\mathrm{mg}$ only compagnous de voyage. In the deportment of this man there was that deferential courtesy which you see in the manners of respectable tradesmen, who are brought much into intercourse with then superiors in rank, without, however, a tinge of seraility; and his conversation amused and interested me more and more. He told me he had been born on a farm, and had first worked as a farmer's boy, then as a house-carpenter, lastly, as a decorative carver and gilder, so that there was no kind of business to which he could not readily turn his hand. His wife was a good sempstress, and he had brought up all his six children to be useful, giving them such opportuuities of acquiring knowledge as he could. 
Ho regretted his own ignorance, but, as he said, he bad been all his life too busy to find time for reading much. He was, however, resolved that his boys and girls should road, bocause, as he well observed, " erory sort of knowledge, be it much or little, was sure to turn to eccount some time or other." His notions on education, his objections to the common rowtine of common schools, and his vievs for his children, were all marked by the same originality and good sense. Altogether be appeared to be, in overy respect, just the kisd of settler we want in Upper Canads. I was therefore pleased to hear that bitherto bo was bettez satisfied with the little he had seen of this province, than with those states of the Union through which he had journeyed; he axid, truhy, it was more " home-like, more English. liko." I did my best to encourage him in this favorable opinion, promising myself that the little might be able to do to promote his views, that I rould do."

While the conversation was thus kept up with wonderful pertinacity, considering that our vehicle. was reeling and tumbling along the detestable road, pitching like a scowk among the breakers in a lake.

- And I did my best, in referring him by letter to Dr. Dunlop; for, though personally unknown to him, I knew that my emigrant was exactly the man to deserve and obtain his notice. I also, wrote to Chief Justice Robinson in his faror, and invited. him to come to us on his arrival in Toronto, promising him the Chancellor's good-will and assistance. But I never heard of the man again, nor could I find, before I left Canada, that hia name was registered as a purchaser of land. 
trorm, our driver stopped before a vile little log but, orer the door of which bung crooked-wise a board, setting forth that " wiskey and tabacky" were to bo tad there. The windows were broken, and the loud voice of some intoxicated wretch was heard from within, in one uninterrupted torrent of oaths and blasphemies, so shocking in their variety, and so new to my ears, that I was really horror-struck.

After leaving the hut, the coach stopped again. I ealled to the driver in some terror, "You are not surely going to admit that drunken man into the coach ?" He replied coolly, " $O$ no, I an't; don't you be afear'd !" In the next moment be opened the dbor, and the very wretch I stood in fear of was eumbled in head foremost, smelling of spirits, and looking - $O$ most horrible! Expostulation was in rain. Without even listening, the driver shut the door, and drove on at a gallop. The rain was at this time falling in torrents, the road knee-deep in mud, the wild forest on either side of us dark, grim, impenetrable. Help there was none, nor remedy, nor redress, nor hope, but in patience. Here, then, was one of these inflictions to which speculative eravellers are exposed now and then, appearing, for the time, to outweigh all the possible advantages of experience or knowledge bought at such a price.

I had never before in my whole life been obliged co endure the presence or proximity of such an object for two minutes together, and the astonishment, borror, disgust, even to sickness and loathing, which it now inspired, are really unspeakable. The Enginhmen, placing himself in the middle seat, in frost 
of his wifo and myeelf, did his beat to proton w from all powibility of contact with the object of our abomination; while the wretched boing, awrare. of our adrerse foeling, put on at one moment an air of chuctling celf-complacency, and the next glarod ca us with ferocious defiance. When I had recovered myeolf sufficiently to obserye, I saw, with added horror, that ho was no more than fire-and-twenty. probably much younger, with a face and figure which muat hare been by nature not only fine, but uncommonly fino, though now deformed, degraded, haggard and inflamed with filth and inebriety $\rightarrow$ a dreadful and bumiliating spectacle. Some glimmering remains of cense and decency prevented him from swearing and blaspheming when once in the coach; but he abused worribly : bis nasal accent, and his drunken objurgations against the old country, and all who came from it, betrayed his own birth and breeding to have been on the other side of the Niagara, or "down eart." Once he addressed some words to me, and, effended by my resolute silence, he exclaimed, with a scowl, and a hiccup of abomination at every word, "I ahould like-to know-madam-how-I came vader your diabolical influence?" Here my friend the emigrant, seeing my alarm, interposed, and a scene ensued, which, in spite of the horrors of this horrible propinquity, was irresistibly comic, and not without its pathetic significance too, now I come to think of it. The Englishman, forgetting that the condition of the man placed him for the time beyond the influence of reasoning or sympathy, began with grave and benevolent earnestness to lecture him on 
his proftigate habits, expressing his amazement and his pity at seeing such a fine young man fallen into such evil ways, and exhorting him to mend, the fellow, meanwhile, rolling himself from side to side with laughter. But suddenly his countenance. changed, and be said with a wistful expression, and the tears in his eyes, "Friend, do you believe in the. devil ?"

" Yes, I do," replied the Englishman, with solemnity.

"Then it's your opinion, I guess, that a man may. be tempted by the devil ?"

"Yes, and I should suppose as how that has been your case, friend ; though," added he, looking at him from head to foot with no equirocal expression. "I think the devil himself might have more charity than to put a man in such a pickle."

"What do you mean by that?" exclaimed the wretch fiercely, and for the first time uttering a horrid oath. The emigrant only replied by shaking bis head significantly; and the other, after pouring forth a volley of abuse against the insolence of the "old country folk," stretched himself on his back, and kicking up bis legs on high, and setting his feet against the roof of the coach, fell asleep in this attitude, and snored, till, at the end of a long hour, he was tumbled out at the door of another drinking hovel as he had tumbled in, and we saw him no more.

The distance from the town of Niagara to Hamilton is about forty miles. We had left the former place at ten in the morning, yet it was nearly mid- 
night befose we arrived, having had no refreshment during the whole day. It was market-day, and the sime of the assizes, and not a bed to be bad at the oaly tolerable botel, which, I should add, is large and commodious. The people were civil beyond measure, and a bod was made up for me in a back parlour, into which I sank half starved, and very completely tired.

The next day rose bright and beautiful, and I smused myself walking up and down the pretty sown for two or three bours.

Hamilton is the capital of the Gore district, and one of the most flourishing places in Upper Canada. It is aituated at the extreme point of Burlington Bay, at the head of Lake Ontario, with a population, annually iucreasigg, of about three thousand. The town is about a mile from the lake shore, a epace which, in the course of time, will probably be corered with buildings. I understand that seventeen - thousand bushels of wheat were shipped here in one month. There is a bank here; a court-house and jail looking unfinished, and the commencement of a public reading-room and literary society, of which I cannot speak from my own knowledge, and which appears as yet in embryo. Some of the linendrapers' shops, called here clothing stores, and the grocery stores, or shops for all the descriptions of imported merchandise, made a very good appearance; and there was an air of business, and bustle, and animation about the place which pleased me. I caw no bookeoller's shop, but a few books on the 
shelves of a grocery store, of the most common and coarse description.

Allen $\mathrm{M} \cdot \mathrm{Nab}$, the present speaker of the bouse of assembly, has a very beautiful house here, and is a principal merchant and proprietor in the town; but he was at this time absent. I had heard much of Mr. Cattermole, the author of a very clever little book addressed to emigrants, and also a distinguished inhabitant of the place. I wished to see this gentleman, but there were some difficulties in finding him, and, after waiting some time, $I$ was obliged to take my departure, a long day's journey being before me.

I hope you have a map of Canada before you, or at band, that what I am now going to tell you may be intelligible.

They have projected a railroad from Hamilton westward through the London and Western districts-certainly one of the grandest and most useful undertakings in the world-in this world, I mean. The want of a line of road, of an accessible market far agricultural produce, keeps this magnificent country poor and ignorant in the midst of unequal capabilities. If the formation of the Rideau Canal, in the eastern districts, (connecting Lake Ontario with the Ottawa river,) has, in spite of many disadvantages in the soil and locality, brought that part of the province so far in advance of the rest, in population, wealth, and intelligencewhat would not a railroad do for them here, where the need is at least as great-the resources, natural and accidental, much superior-and the prospect of 
adrantage, in orery point of view, infinitely more promising ?

Under all disadvantages, this part of the province has been the usual route of emigrants to the Western States of the Union; for, as you will perceive by a glance at the map, it is the shortest road to Michigan and the Illinois by some hundreds of miles. If there were but a railroad, opening a direct communication through the principal settlements between Hamilton on Lake Ontario, and Sandwich at the head of Lake Erie, there is no calculating the advantages that must arise from it eren immediate advantage ; but "want of capital," as I hear all rourd me-and they might add want of energy, want of enterprise, want of every thing needful, besides money - the one thing most needful-are likely to dofer the completion of this magnificent plan for many years. I wonder some of our great speculators and monied men in England do not speculate here, instead of sending their money to the United States; $\rightarrow$ rather I do not wonder, seeing what I see. But 1 wish that the government would do something to remove the almost universal impression, that this province is regarded by the powers at home with distrust and indifference-something to produce more confidence in public men and public measures, without which there can be no enterprise, no prosperity, no railroads. What that something is, being no politician nor political economist like Harriet Martineau, I cannot point out, nor even conjecture. I have just sense enough to see, to feel, that something 
must be done-that the necessity speaks in every form all round me.

I should not forget to mention, that in the Niagara and Gore districts there is a vast number of Dutch and German settlers, favorably distinguished by their industrious, sober, and thriving habits. They are always to be distinguished in person and dress from the British settlers; and their houses, and churches, and above all, their burial-places, hare a distinct and characteristic look. At Berlin, the Germans have a printing-press, and publish a newspaper in their own language, which is circulated among their countrymen through the whole province.

At Hamilton I hired a light wagon, as they call it, a sort of gig perched in the middle of a wooden tray, wherein my baggage was stowed; and a man to drive me over to Brandtford, the distance being about five-and-twenty miles, and the charge-five dollars. The country all the way was rich, and beautiful, and fertile beyond description-the roads abominable as could be imagined to exist. So I then thought, but have learned since that there are degrees of badness in this respect, to which the human imagination has not yet descended. I remember a space of about three miles on this road, bordered entirely on each side by dead trees, which has been artificially blasted by fire, or by girdling. It was a ghastly forest of tall white spectres, strangely contrasting with the glowing luxurious bliage all around.

The pity I have for the trees in Canada, shows 
bow far I am yet from being a true Canadian. How do we know that trees do not feel their downfal 1 We know nothing about it. The line which divides animal from vegetable sensibility is as uhdefined as the line which divides animal from humen intelligence. And if it be true " that nothing dies on earth but nature mourns," how must she mourn for these, the mighty children of her bosotn -her pride, her glory, ber garment? Without exactly believing the assertion of the old philosopher, that a tree fecls the first stroke of the axe, I know I never witness nor hear that first stroke without a shudder; and as yet I cannot look on with indifference, far less share the Canadian's exultation, when these huge oaks, these umbrageous elms and stately pines, are lying prostrate, lopped of all their honors, and piled in heaps with the brushwood, to be fired-or burned down to a charred and blackened fragment - or standing, leafless, sapless, seared, ghastly, having been " girdled," and left to perish. The "Fool $i$ ' the Forest," moralized not more quaintly over the wounded deer, than I could sometimes over those prostrated and mangled trees. I remember in one of the clearings to-day, one particular tree which had been burned and blasted; only a blackened stump of mouldering bark-a mere shell remained; and from the centre of this, as from some hidden source of vitality, sprang up a young green shoot, tall and flourishing, and fresh

- Quoted by Evelyn.

+ As You Like It. 
and leafy. I looked and thought of hope! Why, indeed, should we ever despair? Can Heaven do for the blasted tree what it cannot do for the buman heart?

The largest place we passed was Ancaster, very prettily sicuated among pastures and rich woods, and rapidly improving.

Before sunset I arrived at Brandtford, and took. a walk about the town and its environs. The situation of this place is unost beautiful-on a hill above the left bank of the Grand River. And as I stood and traced this noble stream, winding through richly-wooded flats, with green meadows and cultivated fields, I was involuntarily reminded of the Thames near Richmond; the scenery has the same character of tranquil and luxuriant beauty.

In Canada the traveller can enjoy little of the interest derived from association, either historical or poetical. Yet the memory of General Brock, and some anecdotes of the last war, lend something of this kind of interest to the Niagara frontier; and this place, or rather the name of this place, has certain recollections connected with it, which might well make an idle contemplative wayfarer a little pensive.

Brandt was the chief of that band of Mohawk warriors which served on the British side during the American War of Independence. After the termination of the contest, the "Six Nations" left their ancient seats to the south of Lake Ontario, and having received from the English government a grant of land along the banks of the Grand River, 
and the adjacent shore of Lake Erie, they settled here under their chiof, Brandt in 1783. Great part of this land, some of the finest in the province, has lately been purchaced back from them by the government, and settled by thriving English farmers.

Brandt, who had intelligence enough to perceive and acknowledge the superiority of the whites in all the arts of life, was at first anxious for the convemion and civilization of his nation; but $I$ was told by a gentleman who had known him, that after a vivit he paid to England, this wish no longer existed. He returned to his own people with no very sublime idee either of our morals or manners, and diod in 1807.

He is the Brandt whom Campbell has handed down to most undeserved execration as the leader in the massacre at $\mathrm{W}$ yoming. The poet indeed tolls us, in the notes to Gertrude of Wyoming, that all he has said against Brandt must be considered as pure fiction, "for that he was remarkable for his humanity, and not even present at the massacre ;" but the name stands in the text as beretofore, apostrophized as the "accursed Brandt," the "monster Brandt;" and is not this most unfair, to be hitched into elegant and popular rhyme as an amasen by wholesale, and justice done in a little fag-end of prose?

His son, John Brandt, received a good education, and was a member of the house of assembly for his district. He too died in a short time before my arrivel in this country; and the son of his sister, 
Mrs. Kerr, is at present the hereditary chief of the Six Nations.

They consist at present of two thousand five bundred, out of the seven or eight thousand who first settled here. Here, as every where else, the decrease of the Indian population settled on the reserve lands is uniform. The white population throughout America is supposed to double itself on an average in twenty-three years; in about the same proportion do the Indians perish before them.

The interests and property of these Indians are at present managed by the government. The revenue arising from the sale of their lands is in the hando of commiasioners, and much is done for their conversion and civilization. It will, however, be the affair of two, or three, ox more generations; and by that time not many, I am afraid, will be left. Consumption makes dreadful havoc among them. At present they have churches, schools, and an able missionary who has studied their language, beside several resident Methodist preachers. Of the two thousand five hundred already mentioned, the far greater part retain their old faith and customs, having borrowed from the whites, only those habits which certainly " were more hunared in the breach than in the observance." I saw many of these people, and spoke to some, who replied with a quiet, self-possessed courtesy, and in very intelligible Engliob. One group which I met outside the town, consisting of two young men in blanket coats and leggings, one haggard old woman, with a man's hat on her head, a blue blanket and deer-skin moccasins, and a 
very beautiful girl, apparently not more than fifteen, similarly dressed, with long black hair hanging loose over her face and sboulders, and a little baby, many shades fairer than herself, peeping from the folds of ber blanket behind, altogether reminded me of a group of gipsies, buch as I have seen on the borders of Sherwood Forest many years ago.

The Grand River is navigable for steam-boats from Lake Erie up to the landing-place, about two miles below Brandtford, and from thence a canal is to be cut, some time or other, to the town. The present site of Brandtford was chosen on account of those very rapids which do indeed obstruct the navigation, but turn a number of mills, here of the first importance. The usual progreess of a Canadian village is this : first on some running stream, the arection of a saw-mill and grist-mill for the eonvenience of the neighboring scattered settlers; then a few shanties or log-houses for the work-people; then a grocery-store; then a tavern-a chapel-per chance a school-bouse-und so veiter, as the Germans say.*

- The erection of a church or chapel generally precedes that of a sehool-house in Upper Canada, but the mill and the tavern invariably precede both. "In the United States," says Mr. Schoolcraft, "the first public edifice is a court-house; then a jail ; then a school-houso-perbaps an academy, where religious cxencises may be occasionally held; but a house of public worthip is the result of a more mature state of the settlement. If," he adds, "we have sometimes been branded as litigious, it is not altogether without foundation; and, notwithstanding the very humble eatimate which foreign reviewers have been pleased to maks of our literary character and attainments, there is more 
Not having been properly forowramed, I unfortwtunately allowed the driver to take me to a wrong inn. I ought to have put up at the Maneion-bouse, well-kept by a retired half-pay British officer; instead of which I was brought to tho Commercial Hotel, newly undertaken by an American. I sont to the landlord to say I wished to speak to him sbout proceeding on my journey next day. The next moment the man walked into my bed-room without hesitation or apology. I was too much accustomed to foreign manners to be greatly discomfited ; but when he proceeded to fling his hat down on my bed, and throw himself into the only armchair in the room, while I was standing, I must own I did look at him with some surprise. To those who have been accustomed to the servile courtesy of English innkeopers, the manners of the innkeepers in the United States are not pleasant. I cannot say they ever discomposed me : I always met with civility and attention; but the manners of the country innkeepers in Canada are worse than any thing you can meet with in the United States, being generally kept by refugee Americans of the loweat class, or by Canadians who, in affecting American manner: and phraseology, grossly exaggerate both.

In the present case I saw at once that no incivility was intended; my landlord was ready at a fair price to drive me over himself, in his own "wagon," to Woodstock; and after this was settled, finding, after a fow questions, that the man was really a most

likelihood of our obtaining the reputation of a learned than a pious people."-Schoolcraft's Travels. 
ctupid, igmorant fellow, I turned to the window, and cook up a book, as a hint for him to be gone. Ho continued, howerer, to lounge in the chair, rocking bimeelf in vilence to and fro, till at last he did cordescend to take my hint, and to take his departure.

Though tired beyond expression, I was for some time prevented from going to rest by one of those disgraceful scenes which meet me at every tarn. A man in the dress of a gentleman, but in a state of brutal intoxication, was staggering, swearing, vociforating, beneath my window, while a party of men, also respectably dressed, who were smoking and drinking before the door, regarded him with amusement or indifierence; some children and a fow Indians were looking on. This person, as the maidcervant informed me, was by birth a gentleman, and hed good practice in the law. "Three years ago there wasn't a smarter (cleverer) man in the district :" now he was ruined utterly in heelth, fortune, and obaracter. His wife's relations had taken her and her children away, and had since clotbed him, and allowed him somothing for a subsistence. He continued to disturb the whole neighborhood for two hours, and I was really surprised by the forbearance with which he was treated.

Next morning I took another walk. There are several good shops and many houses in progress, some of them of brick and stone. I met two or three well-dressed women walking down Colbornestreet; and the people were bustling about with animated faces-a strong contrast to the melanchoy, indolent-looking Indians. I understand that there 
are now about twelve hundred inhabitants, the population having tripled in three years : and they have a newspaper, an agricultural society, a postoffice ; a Congregational, a Baptist, and Methodist church, a large chair manufactory, and other mills and manufactories which I had no time to visit.

At ten o'clock, a little vehicle, like that which brought me from Hamilton, was at the door; and I set off for Woodstock, driven by my American landlord, who showed himself as good-natured and civil as hie was impenetrably stupid.

Ne one who has a single atom of imagination, can travel through these forest roads of Canada without being strongly impressed and excited. The seemingly interminable line of trees before you; the boundless wilderness around; the mysterious depths amid the multitudinous foliage, where foot of man hath never penetrated, -and which partial gleams of the noontide sun, now seen, now lost, lit up with a changeful, magical beauty - the wondrous splendor and novelty of the flowers-the silence, unbroken but by the low cry of a bird, or hum of insect, or the splash and croak of some huge bullfrog,- - the solitude in which we proceeded mile after mile, no human being, no human dwelling within sight, - are all either exciting to the fancy, or oppressive to the spirits, according to the mood one'may be in. Their effect on myself I can hardly describe in words. 
I obsorved some birds of a specien new to mo; there was the lovely blue-bird, with its brilliant violot plumage; and a most gorgeous species of woodpocker, with a black head, white breast, and beck and wings of the brightest scarlet; hence it is called by some the field-officer, and more generally the cock of the woods. I should have called it the coxcomb of the woods, for it came flitting across our road, clinging to the trees before us, and remaining portinaciously in sight, as if conscious of its own splendid array, and pleased to be admired.

There was also the Canadian robin, a bird as large as a thrusb, but in plumage and shape resembling the sweet bird at home " that wears the scarlet stomachor." There were great numbers of small birds of a bright yellow, like caneries, and I believe of the same genus. Sometimes, when 1 looked up from the depth of foliage to the blue firmament above, I saw the eagle sailing through the air on apparently motionless wings. Nor let me forget the oplendor of the flowers which carpeted the woods on either side. I might have exclaimed with Eichondorff,

"O Welt! Du schōne welt, Du!

- Mann sieht Dich vor Blümen kaum!

for thus in some places did a rich embroidered pall of flowers literally kide the earth. There those beautiful plants, which we cultivate with such care in our gardens, azalias, rhododendrons, all the gorgeous family of the lobelia, were flourishing in 
wild luxuriance. Festoons of creeping and parasitical plants hung from branch to branch. The purple and scarlet iris, blue larkspur, and the elegant Canadian columbine with its bright pink flowers; the scarlet lychnis, a species of orchis of the most dazzling geranium-color, and the white and yellow and purple cyprepedium," bordered the path, and a thousand others of most resplendent hues, for which I knew no names. I could not pass them with forbearance, and my Yankee driver, alighting, gathered for me a superb bouquet from the swampy margin of the forest. I contrived to fasten my flowers in a wreath along the front of the wagon, that I might enjoy at leisure their novelty and beauty. How lavish, how carelessly profuse is nature in her handiwork! In the interior of the cyprepedium, which I tore open, there was variety of configuration, and color, and gem-like richness of ornament, enough to fashion twenty different flowers; and for the little fly in jewrelled cuirass, which I found couchod within its recesses, what a palace! that of Aladdin could hardly have been more splendid!

But I spare you these fantastic speculations and cogitations, and many more that came flitting across my fancy. I am afraid that, old as I am, my youth has been yokefellow with my years, and that $I$ am yet a child in some things.

From Brandtford we came to Paris, a new settlement, beautifully situated, and thence to Woodstock,

- From its resemblance in form to a shoe, this splendid fower bears every where the same name. The English call it lady's slipper; the Indians know it as the moccasin flower. 
a distance of eighteen miles. There is no villege, only isolated inns, far remored from each other. In one of these, kept by a Frenchman, I dined on milk and eggs and excelleut bread. Here I found every appearance of prosperity and plenty. The landlady, an American woman, told me they had come into this wilderness twenty years ago, when there was not another farm-house within fify miles. She had brought up and settled in comfort several sons and daughters. An Irish farmer came in, who had rofreahments spread for bim in the,porch, and with whom I had some amusing conversation. He, too, was prospering with a large farm and a large family. -here a blessing and a means of wealth, too often in the ald country a curse and a burthen. The good-petured fellow was extremely scandalized by my homely and temperate fart, which he besought mo to mend by accopting a glass of whiskey out of his own travelling-store, genuine potheen, which he swore deeply, and not nnpoetically, " had never seen God's beautiful world, nor the blessed light of day, since it had been bottled in ould Ireland." He told me, boantingly, that at Hamilton he had made eight hundred dollars by the present extraordinary rise in the price of wheat. In the early part of the year, wheat bad been selling for three or four dollars a bushel, and rose this summer to twelve and fourtoen dollars a bushel, owing to the immense quantities exported during the winter to the back settlements of Michigan and the Illinois.

The whole drive would have been productive of unmixed enjoyment, but for one almost intolerable 
draw-back. The roads were throughout so execrably bad, that no words can give you an idea of them. We often sank into mud-holes above the axletree; then over trunks of trees laid across swamps, called here corduroy roads, were my poor bones dislocated. A wheel here and there, or broken shaft lying by the way-side, told of former wrecks and disas. ters. In some places they had, in desperation, flung huge boughs of oak into the mud abyss, and covered them with clay and sod, the rich green foliage projecting on either side. This sort of illusive contrivance would sometimes give way, and we were nearly precipitated in the midst. By the time we arrived at Blandford, my hands were swelled and blistered by continually grasping with all $\mathrm{my}$ strength an iron bar in front of my vehicle, to pre-. vent myself from being flung out, and my limbs ached wofully. I never beheld or imagined such roads. It is clear that the people do not apply any, even the commonest, principles of road-making; no drains are cut, no attempt is made at levelling or preparing a foundation. The settlers around are too much engrossed by the necessary toil for a daily subsistence to give a moment of their time to roadmaking, without compulsion or good payment. The statute labor does not appear to be duly enfurced by the commissioners and magistrates, and there are no laborers, and no spare money; specie, never very plentiful in these parts, is not to be had at present, and the $500,000 l$., roted during the last session of the provincial parliament for the repair of roads, is not yet even raised, I b elieve. 
Nor is this all : the vile state of the roads, the very little communication between places not far distant from each other, leave it in the power of illdisposed persons to sow mischief among the ignorant, isolated people.

On emerging from a forest road seven miles in longth, we stopped at a little inn to refresh the poor jaded horses. Several laborers were lounging about the door, and I spoke to them of the horrible state of the roads. They agreed, one and all, that it was entirely the fault of the government; that their welfare was not cared for; that it was true that money had been roted for the roads, but that before any thing could be done, or a shilling of it expended, it was always necessary to write to the old country to ask the king's permission-which might be sent or not-who could tell! And meantime they were ruined for want of roads, which it was nobody's business to reclaim.

It was in vain that $I$ attempted to point out to the orator of the party the falsehood and absurdity of this notion. He only shook his bead, and said he knew better.

One man observed, that as the team of Admiral $\mathrm{V}$ - (one of the largest proprietors in the district) had lately broken down in a mud-hole, there was some hope that the roads about here might be looked to.

About sunset, I arrived at Blandford, dreadfully weary, and fevered, and bruised, having been more than nine hours travelling twenty-five miles; and I must needs own that not all my savoir faire could 
prevent me from feeling rather dojected and shy, as I drove up to the residence of a gentleman, to whom, indeed, I had not a letter, but whose family, as I had been assured, were prepared to receive me. It was rather formidable to arrive thus, at fall of night, a wayfaring, lonely woman, spiritless, half-dead with fatigue, among entire strangers : but my reception set me at ease in a moment. The words, "We bare been long expecting you !" uttered in a kind, cordial voice, sounded " like sweetest music to attending ears." A handsome, elegant-looking woman, blending French ease and politeness with English cordiality, and a whole brood of lively children of all sizes and ages, stood beneath the porch to welcome me with smiles and outstretehed hands. Can you imagine my bliss, my gratitude ?-no!-impossible, unless you had travelled for three days through the wilds of Canada. In a few hours I felt quite at home, and my day of rest was insensibly prolonged to a week, spent with this amiable and interesting family-a week, ever while I live, to be remembered with pleasurable and grateful feelings.

The region of Canada in which I now find myself, is called the London District; you will see its situation at once by a glance on the map. It lies between the Gore District and the Western District, having to the south a large extent of the coast of Lake Frie; and on the north the Indian territories, and part of the southern shore of Lake Huron. It voL. $x$. 26 
is watered by rivere flowing into both lakes, but chiefly by the river Thames, which is here (about one hundred miles from its mouth) a small but most beautiful stream, winding like the Isis, at Oxford. Woodstock, the nearest village, an I suppose I must in modesty call it, is fast rising into an importent town, and the whole district is, for its scenery, fertility, and advantages of every kind, perhaps the fineat in Upper Canada.

The society in this immediate neighborhood is particularly good; several gentlemen of family, superior education, and large capital, (among whom is the brother of an English and the son of an Irish peer, a colonel and a major in the army,) have made very extensire purchases of land, and thoir estates are in flourishing progress.

One day we drove over to the settlement of one of these magnificos, Admiral V — , who has already expended upwards of twenty thousand ponnds in purchases and improvements. His house is really a curionity, and at the first glance reminded me of an African village-a sort of Timbuctoo set down in the woods; it is two or three miles from the high road, in the midst of the forest, and looked as if a number of log-huts had jostled against each other by accident, and there stuck fast.

The admiral had begin, I imagine; by erecting, as is usual, a log-house, while the woods were clearing; then, being in want of apace, he added an-

- The arerage produce of an acre of land is greater throughout Canada than in England. In these western districts greater than in the rest of Canada. 
other, then another and another, and so on, all of different shapes and sizes, and full of a seaman's contrivances-odd galleries, passages, porticos, corridors, saloons, cabins and cupboards; so that if the outside reminded me of an African village, the interior was no less like that of a man-of-war.

The drawing-room, which occupies an entire building, is really a noble room, with a chimney in which they pile twenty oak loge at once. Around this room runs a gallery, well lighted with windows from witbout, through which there is a constant circulation of air, keeping the room warm in winter and cool in summer. The admiral has besides so many ingenious and inexplicable contrivances for warming and airing his house, that no insurance office will insure him upon any terms. Altogether it was the most strangely picturesque sort of dwelling I eres beheld, and could boast not only of luxuries and comforts, such as are seldom found so far inland, but "cosa altre più cara," or at least "piu rara." The admiral's sister, an accomplished woman of independent fortune, has lately arrived from Europe, to take up her residence in the wilds. Having recently spent some years in Italy, she has brought out with her all those pretty objects of virtù, with which English travellers load themselves in that country. Here, ranged round the room, I found views of Rome and Naples; tazzi, and marbles, and sculpture in lava, or alabaster ; miniature copies of the eternal Sibyl and Cenci, Raffaelle's Vatican, \&c.- - things not wonderful nor rare in themselvesthe wonder was too see them here. 
The woods are jet close up to the house; but there, is a fine well-cultivated garden, and the procoes of cloaring and log-burning proceeds all around with great animation.

The good admiral, who is no longer joung-ax contraire- has recently astonished the whole neighborhood - nay, the whole province, by taking to himself a young, very young wife, of a station very in ferior to bis own. There have boen considerable doubts in the neighborhood as to the propriety of visiting the young lady-doubts which appear to me noither reasonable nor good-natured, and which will, no dowbe, give way before the common sense and kind foeling of the poople. Selden might well ary, that of all the actions of a man's life, his mar riage was that in which others had the least concern, and were sure to meddle the most! If this gentleman be unhappy, be has committed a folly, and will be punished for it sufficiently without the inter ference of bie friends and neighbors. If he be happy, and they say he is, then he bas committed no folly, and may laugh at them all round. His good sister has come out to countemance him and bis ménage-a proof equally of her affection and her understanding. I can now only wish her a continuance of the same cheerfulness, fortitude and perseverance she has bitherto shown-virtues very necessary in this new province.

On Sunday, we attended the pretty little church at Woodetock, which was filled by the neighboring settlers of all classes : the service was well read, and the hymns were sung by the ladies of the con- 
gregation. The sermon, which treated of some abstract and speculative point of theology, seemed to me not well adapted to the sort of congregation assembled. The situation of those who had here met together to seek a new existence in a new world, might have afforded topics of instruction, praise, and gratitude, far more practical, more congenial, more intelligible than a mere controversial essay on a disputed text, which elicited no remark nor sympathy that I could perceive. After the service, the congregation remained some time assembled before the church-door, in various and interesting groups - the well-dressed families of settlers who had come from many miles' distance, in vehicles well-suited to the roads-that is to say, carts, or, as they call them here, teams or wagons ; the belles and the beaux of "the Bush," in Sunday trim-and innumerable children. Many were the greetings and inquiries; the news and gossip of all the neighborhood had to be exchanged. The conversation among the ladies was of marriages and births-lamentations on the want of servants and the state of the roads-the last arrival of letters from England-and speculations upon the character of a new neighbor come to settle in the Bush: Among the gentlemen, it was of crops and clearings, lumber, price of wheat, roadmending, deer-shooting, log-burning, and so forthsubjects in which I felt a lively interest and curionity ; and if I could not take a very brilliant and prominent part in the discourse, I could at least listen, like the Irish corn-field, " with all my ears."

I think it was this day at dinner that a gentloman 26* 
dewcribed to me a family of Mohawk Indians, comaisting of seren individuals, who had encamped uporr eome of his uncleared land in two wigwams. They had made their first appearance in the early spring, and had since subsisted by bunting, selling their renison for whiskey or tobacco; their appearance and situation were, he said, most wretched, and their indolence extreme. Within three months, five out of the seren were dead of consumption; two only were loft-languid, squalid, helpless, hopeless, boartles. 
Afrer several pleasant and interesting visits to the neighboring settlers, I took leave of my hospitable friends at Blandford with deep and real regret ; and, in the best and only vehicle which could be procured-videlicet, a baker's cart-set out for London, the chief town of the district ; the distance being about thirty miles-a long day's journey; the cost seven dollars.

The man who drove me proved a very intelligent and civilized person. He had come out to Canada in the capacity of a gentleman's servant; he now owned some land-I forget how many acres-and was besides bakergeneral for a large neighborbood, rarely receiving money in pay, but wheat and other farm produce. He had served as constable of the district for two years, and gave me some interesting accounts of his thief-taking expeditions through the wild forests in the deep winter nights. He considered himself, on the whole, a prosperous man. He said he should be quite happy here, were it not for his wife, who fretted and pined continually after hes "home."

"Bul," said I, "surely wherever you are, is her home, and she ought to be happy. where she sees you getting on better, and enjoying more of comfort and independence than you could have hoped to obtain in the old country."

"Well, yes," said he, hesitatingly; "and I can't 
say but that my wife is a good woman : I've no particular fault to find with her; and it's very natural the should mope, for she has no friend or acquaintance, you see, and she doesn't take to the people, and tho waye bere; and at bome she had her mother and her aister to talk to; they lived with us, you see. Then, I'm out all day long, looking after my busineas, and she foels quite lonely like, and she's a crying when I come back - and I'm sure I don't know what to do!"

The case of this poor fellow with his dicontented wife is of no unfrequent occurrence in Canada; and among the better class of settlers the matter is worse atill, the ouffering more acute, and of graver consequences.

I have not often in my life met with contented and cheerful-minded women, but I nover met with so many repining and discontented women as in Canada I never mot with one woman recently settled here, who conoidered horself bappy in ber new home and country: I heard of ono, and doubtless there are others, but they are exceptions to the general rule. Those born here, or brought here early by their pa. rents and relations, soemed to mo very happy, and many of them had adopted a sort of pride in their new country, which I liked much. There was always a great desire to visit Fingland, and some little airs of self-complacency and superiority in those who had been there, though for a few months only; but all, without a single exception, returned with pleasure, unable to forego the early habitual influences of their native land. 
I like patriotism and nationality in women. Among the German women both these feelings give a strong tincture to the character; and, seldom disunited, they blend with peculiar grace in our sex: but with a great statesman they should stand well distinguished. Nationality is not always patriotism, and patriotism is not, necessarily, nationality. The English are more patriotic than national; the Americans generally more national than patriotic; the Germans both national and patriotic.

I have observed that really accomplished women, accustomed to what is called the best society, have more resources here, and manage better, than some women who have no pretensions of any kind, and whose claims to social distinction could not have been great any where, but whom I found lamenting over themselves as if they had been so many exiled princesses.

Can you imagine the position of a fretful, frivolous woman, strong neither in mind nor frame, abandoned to her own resources in the wilds of Upper Canada? I do not believe you can imagine any thing so pitiable, so ridiculous, and, to borrow the Canadian word, "so shiftless."

My new friend and kind hostess was a being of quite a different stamp; and though $I$ believe she was far from thinking that she had found in Canada a terrestrial paradise, and the want of servants and the difficulty of educating her family as she wished, were subjects of great annoyance to her, yet these and other evils she had met with a cheerful spirit. Here, amid these forest wilds, she had recently 
- given birth to a lovely baby, the tenth, or indeed I beliove the twelfth of a flock of manly boys and blooming girls. Her eldest daughter mean time, a fair and elegant girl, was acquiring, at the age of fiftoen, qualities and habits which might well make ample amends for the possessing of mere accomplishments. She acted as a manager in chief, and glided about in her household arocations with a serene and quiet grace which was quite charming.

The road, after leaving Woodstock, pursued the course of the winding Thames. We passed by the bouse of Colonel Light, in asituation of superlative natural beauty on a rising-ground above the river. A lawn, tolerably cleared, sloped down to the margin, while the opposite shore rose clothed in varied woods which had been managed with great taste, and a feoling for the picturesque not common here; but the Colonel being himself an accomplished artiot accounts for this. We also passed Beechville a small, but besutiful village, round which the soil is reckoned very fine and fertile; a number of most rospectablo settlers have recently bought land and erected houses here. The next place we came to was Oxford, or rather, Ingersol, where we stopped to dine and rest previous to plunging into an extonsire forest, called the Pine Woods.

Oxford is a little village, presenting the usual oaw-mill, grocery-store and tavern, with a dozen shanties congregated on the bank of the stream, which is here rapid and confined by high banks. Two back-woodsmen were in deep consultation over - wagon which had broken down in the midst of 
that very forest road we were about to traverse, and which they described as most execrable-in some parts even dangerous. As it was necessary to gird up $m y$ strength for the undertaking, I laid in a good dinner, consisting of alices of dried renison, broiled; hot cakes of Indian corn, eggs, butter, and a bowl of milk. Of this good fare 1 partook in company with the two back-woodemen, who appeared to me perfect specimens of their clase-tall and strong, and bronzed and brawny, and sbaggy and unshaven-very much like two bears set on their hind legs; rude but not uncivil, and spare of speech, as men who bad lived long at a distance from their kind. They were too busy, boweter, and so was I, to feel or express any mutual curiosity; time was valuable, appetite urgent-so we discussed our venison steaks in silence, and after dinner I proceeded.

The forest land through which I had lately paseed, was principally covered with hard timber, as oak, walnut, elm, basswood. We were now in a forest of pines, rising tall and dark, and monotonous on either side. The road worse certainly " than fancy ever feigned or fear conceived," put my neck in perpetual jeopardy. The driver had often to dismount, and partly fill up some tremendous hole with boughs before we could pass-or drag or lift the wagon over trunks of trees-or we sometimes sank into abysses, from which it is a wonder to me that we ever emerged. A natural question werewhy did you not get out and walk ?-Yes indeed ! I only wish it bad been possible. Immediately 
on the bordor of the road 20 called, was the wild, angled, untrodden thicket, as impervious to the foot as the road wes impaseable, rich with regetation, variegated rendure, and flowers of loveliest dye, but the haunt of the rattlesnake, and all manner of creeping and living things not pleasent to encounter, or even to think of.

The mosquitos, too, began to be troublesome; but not being yet in full force, I contrived to defend myeelf protty well, by waving. a green branch before we whenever my two hands were not employed in forcible endearors to keep my seat. These coren miles of pine forests we traversed in three hours and a half; and then succeeded some miles of open flat country, called the oak plains, and 80 called because covered with thickets and groups of oak, dispersed with a park-like and beautiful effoct; und still flowers, flowers every where. Tho coil appeared sandy, and not so rich as in other parts." The road was comparatively good, and as we approached London, clearing new settlements appeared on every side.

The sun had set amid a tumultuous mass of lurid threatening clouds, and a tempest was brooding in the air, when I reached the town, and found very tolerable accommodations in the principal inn. I

- It is not the most open land which is most desirable for a settler. "The land," says Dr. Dunlop in his admirable little book, "is rich and lasting, just in proportion to the size and quantity of the timber which it bears, and therefore the more trouble he is put to it in clearing his land, the better will it ropay him the labor he has expended on it." 
was so terribly bruiced and beaten with fatigue, that to move was impossible, and even to speak, too great an effort. I cast my weary aching limbs upon the bed, and requested of the very civil and obliging young lady who attended to bring me some books and newspapers. She brought me thereupon an old compendium of geography, publisbed at Philadelphia forty years ago, and three newspapera. Two of these, the London Gazette and the Freeman's Journal, are printed and published within the district; the third, the New-York. Albion, I have already mentioned to you as baving been my delight and consolation at Toronto. This paper, an extensive double folio, is compiled for the use of the British settlers in the United States, and also in Canada, where it is widely circulated. It contains all the interesting public news in extracts from the leading English journals, with tales, essays, reviews, \&cc., from the periodicals. Think, now, if I had not reason to bless newspapers and civilization! Imagine me alone in the very centre of this vast wild country, a storm raging without, as if beaven and earth had come in collision-lodged and cared for, reclining on a neat comfortable bed, and reading by the light of one tallow candle, (for there was a scarcity either of candles or of candlesticks,) Sergeant Talfourd's speech in the Commons for the alteration of the law of copyright, given at full length, and if $I$ had been worse than "kilt entirely," his noble eulogy of Wordsworth responded to by the cheers of the whole house, would have brought me to life; so did it make my very heart glow with approving sympathy. roL. I. 
In the camo paper, and in the two provincial papers, I found whole columne oxtractod from Mise Martinean's long expected book on Americe. What I now read, fulfilled the highest expectations I had previously formed. There will, of course, be diversity of opinion on many points; but one thing is clear; that she is a good woman, and a lover of truth for truth's sake; and that she has written in a good and womanly spirit, candid and kind ; - stern somo. times, never sharp, never satirical. There is in these paseages at least, an even tono of good-nature and good temper - of high pripciple and high feeling of every kind, which has added to my admiration of her, and makes me long more than ever to see the book itself. There are things in it, apparently, which will not yot be appreciated-but all in good time.

With regard to the law of copyright, I see in another part of the paper that the publishers have taken the alarm, and are beginning to bestir themcolves against it. We shall have them crying out hike the French actresses, "C'est une chose étonnante qu'on ne trouve pas un moyen de so passer dauteurs!" Perhaps the best thing at this moment for all parties would be an international law, which should protect both authors and publishers; for if they have no respect for the property which is the mere produce of the brain, perhaps they will respoct and acknowlodge the existence of property for which a man can prove he has paid hard money. 
July 5.

Taw next morning the wexther continued wory lowering and stormy. I wrote out my little journal for you carefully thus far, and then I received oeveral visiters, who hearing of my arrival, had come with kind ofers of hospitality and attention, such as are woot grateful to a solitary stranger. I had also much conversation relative to the place and people, and the settlements around, and then I took a long walk about the town, of which I here give you the resulte.

When Gorermor Simcoe was planning the foundation of a capital for the whole province, be fixed at first upon the present site of London, struck by its many and obrious advantages. Its central position, in the midet of these great lakes, being at an equal diatance from Huron, Erie, and Ontario, in the finest and most fertile district of the whole province, on the bank of a beautiful stream, and at a safe distance from the frontier, all pointed it out as the most eligible site for a metropolis; but there was the want of land and water communication-a want which still remains the only drawback to ito rising prosperity. A canal or rail-road, running from Toronto and Hamilton to London, then branching off on the right to the harbor of Goderich on Lake Huron, and on the left to Sandwich on Lake Erio, were a gloriou thing !-the one thing need- 
ful to make this fine country the granary and storebouse of the west; for bere all grain, all fruits which Doorish in the south of Europo, might be cultivated with succese- the finest wheat and rice, and hemp and flax, and tobacco. Yot, in spite of this want, coon, I trust, to be aupplied, the town of London hes apruag up and become within ten years a place of great importanco. In eize and population it excoods every town I bave yot visited, except Toronto and Hamilton. The first houso was erected in 1887; it now contains more than two hundred frame or brick houses; and thore are many more building. The population may be about thirteen bundred peoplo. The jail and court-house, comprised in one large otately edifice, soemed the glory of the townspoople. As for the style of architecture, I may not - attempt to name or describe it; but a gentleman informod me, in rather equirocal phrase, that it was "scmerohat godhic." There are fire places of worahip, for the Episcopalians, Presbyterians, Methodiats, Roman Catbolics, and Baptists. The chureh is handsome. There are also three or four schools, and seron taverns. The Thames is very beautiful hore, and navigable for boats and barges. I saw wo-day a large timber raft thoating down the stream, containing many thousand foet of timber. On the whole, I have nowhere seen such evident signs of progress and prosperity.

The population consists principally of artisansas blackemiths, carpenters, builders, all flourishing. There is, I fear, a good deal of drunkenness and profligacy: for though the people have work and wealth, 
they hare neither education nor amusements." Besides the seven tarerns, there is a number of little grocery stores, which are, in fact, drinking houses. And though a law exists, which forbids the sale of -pirituous liquors in small quantities by any but licensed publicans, they easily contrive to elude the . Jaw ; as thus :-a customer enters the shop, and asks for two or three pennyworth of nuts, or cakes, and he receives a few nuts, and a large glass of whiskey. The whiskey, you observe, is giren, not sold, and no one can swear to the contrary. In the same manner the severe law against selling intoxicating li. quors to the poor Indians is continually eluded or violated, and there is no redress for the injured, no punishment to reach the guilty. It appears to me that the government should be more careful in the choice of the district magistrates. While I was in London, a person who bad acted in this capacity was carried from the pavement dead drunk.

Here, as every where else, I find the women of the

- Hear Dr. Channing, the wise and the good:-_"People," ho says, "should be guarded against temptation to unlawful pleasures by furnishing the means of innocent ones. In every com. munity, there must be pleasures, relaxations, and means of agreean ble excitement; and if innocent are not furnished, resort will be had to criminal. Man was made to enjoy as well as to labor; and the state of society should be adapted to this principle of hu. man nature." "Men drink to excess very often to shake off da pression, or to satisfy the restless thirst for agreeable excitement, and these motives are excluded in a cheerful community."

When I was in Upper Canada, I found no means whatever of social amusement for any class, exeept that which the tavern afforded; taverns consequently abounded every where, 
better clase lamenting oror the want of all society, except of the lowest grade in manners and morals. For thuse who havo recently emigrated, and are setled more in the interior, there is abolutely no social intercourse whatever ; it is quite out of the question. They seem to me perishing of ennui, or from the want of sympethy which they cannot obtain, and, what is worse, which they cannot feel ; for being in genoral unfitted for out-door occupations, unable to comprehend or enter into the interests around them, and all their earliest prejudices and ideas of the fitness of things continually outraged in a manner excoodingly unpleasant, they may bo said to live in a perpetual state of inward passive discord and fretful onduranco-

4 Altloo timid and reserved

For oncet, for resistance too inert-

Too weak, for suffering, and for hope too tame."

A gentleman, well known to me by name, who was not a resident in London, but passing through it on his way from a far western settlement up by Lake Huron, wes one of my morning visiters. He had been settled in the Bush for five years, had a beautiful farm, well cleared, well stocked. He was pleased with his prospects, his existence, his occupations : all he wanted was a wife, and on this subject he poured forth a most eloquent appeal.

" Where," said be; " shall I find such a wife as I could, with a safe conscience, bring into these wilds, to share a settler's fate, a settler's home?. You, 
who know your own sex so well, point me out such $a$ one, or tell me at least where to seek her. I am perishing and deteriorating, head and heart, for want of a companion-a wife, in short. I am becoming as rude and coarse as my own laborers, and as hard as my own axe. If I wait five years longer, no woman will be able to endure such a fellow as I shall be by that time-no woman, I mean, whom I could marry-for in this lies my utter unreasonable. ness; habituated to seek in woman those graces and refinements which I have always associated with her idea, I must have them here in the forest, or dispense with all female society whatever. With some one to sympathize with me-to talk to-to embellish the home I return to at night-such a life as I now lead, with all the cares and frivolities of a too artificial society cast behind us, security and plenty all around us, and nothing but hope before us, a life of "cheerful yesterdays and confident tomorrows" - were it not delicious? I want for myself nothing more, nothing better; but-perhaps it is a weakness, an inconsistency ! - I could not love a woman who was inferior to all my preconceived notions of feminine elegance and refinement-inferior to my own mother and sisters. You know I was in England two years ago;-well, I have a vision of a beautiful creature, with the figure of a sylph and the head of a sibyl, bending over her harp, and singing "A te, $O$ cara;" and when I am logging in the woods with my men, I catch myself meditating on that vision, and humming $A$ te, $O$ cara, which somehow or other runs strangely in my head. Now; 
what is to be done? What could I do with thet fair vivion here ? Without coxcombry may I not say, that I noed not ontirely despair of winning tho aroctions of an amiable, elegant woman, and might oren perouade her to confront, for my sake, worse than all this? For what will not your sex do and dare for the sake of us men creatures, savages that we are ? But oren for that reason shall I take adrantage of auch sentiments? You know what this life is-this isolated life in the Bush-and so do I; but by what words could I make it comprehensible to a fino lady? Cortainly I might draw such a picture of it as should delight by its novelty and romance, and deceive even while it does not deviate from the truth. A cottage in the wild woods-solitude and love-the world forgetting, by the world forgot-the doer come skipping by-the red Indian brings game, and lays it at ber feet-how pretty and bow romantic! And for the first few months, perhaps the first year, all goes well; but how goes it the next, and the next? I have observed with re. gard to the women who come out, that they do well enough the first year, and some even the second; but the third is generally fatal : and the worst with

- you women-or the best shall I not say ?-is, that you cannot, and do not, forget domestic ties left behind. We men go out upon our land, or to the chase, and the women, poor souls, sit, and sew, and think. You have seen Mrs. A. and Mrs. B., who came out here, as I well remember, full of health and bloom-what are they now? premature old wamen, sickly, care-worn, without nerve or cheer- 
fulness :-and as for $\mathrm{C} \longrightarrow$, who brought his wife to his place by Lake Simcoe only three years ago, I hear the poor fellow must sell all off, or see his wife perish before his eyes. Would you have me risk the alternative? Or perhaps you will say, marry one of the women of the country-one of the daughters of the Bush. No, I cannot; I must have something different. I may not bave been particularly fortunate, but the women I have seen are in general coarse and narrow minded, with no education. whatever, or with an education which apes all I most dislike, and omits all I could admire in the fashionable education of the old country. What could I do with such women? In the former I might find an upper servant, but no companion-in the other, neither companionship nor help !"

To this discontented and fastidious gentleman I ventured to recommend two or three very amiable girls I hat known at Toronto and Niagara; and I told him, too, that among the beautiful and spirited girls of New-England, he might also find what would answer his purpose. But with regard to Englishwomen of that grade in station and education, and personal attraction, which would content him I could not well speak; not because I knew of none who united grace of person and lively talents with capabilities of strong affection, ay, and suffoient energy of character to meet trials and endure privations; but in women, as now educated, there is a strength of local habits and attachments, a want of oheerful self-dependence, a cherished physical delicacy, a weakness of temperament,--deemed, and 
feleely deomed, in doference to the pride of man, cecential to feminine grace and refinement, -altogocher unfitting thom for a life which were otherwino delightful:- - he active out-of.door life in which abe muat abare and aympachize, and the in-door occupacions which in England are considered servilo; for a woman who cannot perform for berself and others all housobold offices, has no business here. But whon I hoar sumo men declare that they cannot endure to 100 women oat, and othors apeak of brilliant boalth and atrength in young girls as being rade and vulgar, with various notions of the same kind too growly abourd and perverted eron for ridjculo, I cennot wunder at any nonsenaical affectations I moot within my own sex; por do otherwise then pity the mistakes and deficiencies of those who are eagely brought up with the one end and aimto get merried. As you always uood to say, "Lot there bo a demand for a botter article, and a bettor erticle will be supplied."

A woman, blessed with good boalth, a cheerful opirit, larger capabilitie of refloction and action, come knowledge of herself, hor own nature, and the common lot of humanity, with a plain understanding, which hes beon allowed to throw itself out $2 \mathrm{n}$. warped by sickly fancies and prejudices, -moch a woman would be as happy in Canada as any whore in the world. A weak, frivolous, half-educaled, or ill-educated woman may be as miserable in the heart of London as in the heart of the forest. But there ber deficiencies are not so injurious, and are sup- 
16: plied to herwelf and others by the circumstances and ni.-. advantages around her.

I have heard (and seen) it laid down as a princiif: ple, that the purpose-one purpose at least-of oducation is to fit us for the circumstances in which we are likely to be placed. I deny it abeolutely. Even if it could be exactly known (which it cannot) what those circumstances may bo, I should still deny it. Education has a far higber object. I remember to have read of some Russian prince (was it not Potemkin ?) who, when he travelled, was preceded by a gardener, who around his marquee scattered an artificial soil, and stuck into it shrubs and bouquets of flowers, which, while assiduously watered, looked pretty for twenty-four hours perhaps, then withered or were plucked up. What shallow barbarism to take pleasure in such a mockery of a garden! better the wilderness, better the waste! that forest, that rock yonder, with creeping weeds around it! An education that is to fit us for circumstances, seems to me like that Russian garden. No; the true purpose of education is to cherish and unfold the seed of immortality already sown within us ; to develope, to their fullest extent, the capacities of every kind with which the God who made us has endowed us. Then we shall be fitted for all circumstances, or know how to fit circumstances to ourselves. Fit us for circumstances! Base and mechanical! Why not set up at once a "fabrique d'education," and educate us by steam? The human soul, be it man's or woman's, is not, I suppose, an empty bottle, into which you shall pour and cram 
junt what you like, and as you liko; nor a plot of wasto soil, in which you shall sow what you like; but a divino, a living germ planted by an almighty hand, which you may indeed render more or less productive, or train to this or that form-no more. And when you have taken the oak sapling, and dwarfod it, and pruned it, and twisted it, into an ornament for the jardinière in your drawing-room, much here you gained truly; and a pretty figure your specimen is like to make in the broad plain and under the free air of heaven! 
The plan of travel I had laid down for myself did not permit of my making any long stay in London, I was anxious to push on to the Talbot Settlement, or, as it is called here, the Talbot Country, a name not ill applied to a vast tract of land stretching from east to west along the shore of Lake Erie, and of which Colonel Talbot is the sovereign de facto, if not de jure-be it spoken without any derogation to the rights of our lord the king. This immense settlement, the circumstances to which it owed its existence, and the character of the eccentric man who founded it on such principles as have insured its success and prosperity, altogether inspired me with the strongest interest and curiosity.

To the residence of this "big chief," as an Indian styled him - a solitary mansion on a cliff above Lake Erie, where he lived alone in his glory-was I now bound, without exactly knowing what reception I was to meet there, for that was a point which the despotic babits and eccentricities of this hermit-lord of the forest rendered a little doubtful. The reports I had heard of his singular manners, of bis being a sort of woman-hater, who had not for thirty years allowed a female to appear in his sight, I had partly discredited, yet enough remained to make me feel a little nervous. However, my resolution was taken, and the colonel had been apprized of my intended visit, though of his gracious acquiescence $I$ was yet vol. I. 
to learn; s0, putting my trust in Providence, as berecofore, I propared to encounter the old buffalo in his hir.

From the master of the inn at London I hired a rehicle and a driver for eight dollars. The distance was about thirty miles; the road, as my Irish informant assured me, was quite "iligant l" but hilly, and 20 broken by the recent storms, that it was thought I could not reach my destination before nightfall, and I was advised to sleep at the little town of St. Thomas, about twolve or fifteen miles on this side of Port Talbot. Howerer, I was resolute to try, and, with a pair of stout borses and a willing driver, did nol despair. My conveyance from Blandford had boon a baker's cart on springs ; but springs were a luxury I was in future to dispense with. My present vohicle, the best to be procured, was a common cart, with atraw at the bottom; in the midst a seat was suspended on straps, and furnished with a cushion, not of the softest. A board nailed across the front served for the driver, a quiet, demure-looking boy of fifteen or sixteen, with a round straw hat and a fustian jacket. Such was the elegant and appropriate equipage in which the "chancellor's lady," as they call mo here, paid her first visit of state to the "great Colonel Talbot."

On leaving the town, we crossed the Thames on a wooden bridge, and turned to the south through a very beautiful valley, with cultivated farms and extensive clearings on every side. I was now in the Talbot country, and had the adrantage of travelling on part of the road constructed under the colonel's 
direction, which, compared with thoee I had reecedty travelled, was better than tolerable. Whilo wo wero slowly ascending an eminence, I took the opportenity of entering into 2000 discourse with my driver, whose very domure and thoughtfil though boyish face, and very brief but pithy and intelligont replies to some of my question on the roed, had excited my attention. Though perfoctly civil, and reanarably self-poeseseed, he was not communicative or talkative; I had to pluck out the information blade by blade, as it were. And here jou have my catoehism, with quection and nesponse, word for word. as nearly as poscible.

"Were you born in this country ?"

"No; l'm from the old country."

"From what part of it ?"

"From about Glasgow."

"What is your name?"

"Sholto —_."

"Sholto! - that is rather an uncommon name, is it not ?"

"I was eallod Sholto after a son of Lord Douglas. My father was Lord Douglas's gardener."

"How long have you been here?"

"I came over with my father about five years ago." (In 1832.)

"How came your father to emigrate?"

"My father was one of the commuted pensioners, as they call them." He was an ola soldier in the veteran battalion, and be sold his pension of five-

* Of the commuted pensioners, and their fate in Canada, more will be said hereafter. 
pance a day for four years and a grant of land, and cameo cat bore. Many did the like."

"But if he was gardoner to Lord Douglas, he could sot have suefiored from want ?"

* Why, be was not a gardener then; he was a weever; be worked hard enough for us. I remember atton waking in the middle of the night, and woing my father working still at his loom, as if he would nover give orer, whilo my mother and all of we were ealoop."

"All of w !-bow many of you ?"

"There wore six of us; but my oldest brother and myeolf could do something."

"And you all emigrated with your father ?"

"Why, you see, at last be couldn't got no work, and trado was dull, and wo were nigh etarving. I romember I was always hungry then-always."

"And you an camo out "?"

"All but my oldest brother. When we were on the wery to the abip, he got frightened and turned beck, and wouldn't come. My poor mother cried very much, and begged him hard. Now the last we bear of him is, that ho is very badly off, and can't got no work at all."

"Is your father yet alive ?"

"Yes, ho has laud up in Adelaide."

"Is your mother alive?"

"No; she died of the cholera, coming over. You seo the cholera broke out in the ship, and fifty-tbree people died, one after $t$ 'other, and were thrown into the sea. My mother died, and they threw her into the sea. And then my little sister, only nine months 
old, died, because there was nobody to take care of her, and they threw her into the sea-poor little thing !"

“Was it not dreadful to see the people dying around you? Did you not feel frightened for yourself ?"

“ Well-I don't know-one got used to it-it was nothing but splash, splash, all day long-first one, then another. There was one Martin on board, I remember, with a wife and nine children-one of those as sold his pension : he had fought in Spain with the Duke of Wellington. Well, first his wife died, and they threw her into the sea; and then ke died, and they threw him into the sea; and then the children, one after t'other, till only two were left alive; the eldest, a girl about thirteen, who had nursed them all, one after another, and seen them die-well, she died, and then there was only the little fellow left."

"And what became of him?"

"He went back, as I heard, in the same ship with the captain."

"And did you not think sometimes it might be your turn next q"

"No-I didn't; and then I was down with the fever."

"What do you mean by the fever ?"

"Why, you see, I was looking at some fish that was going by the ship in shoals, as they call it. It was very pretty, and I never saw any thing like it, and I stood watching over the ship's side all day long. It poured rain, and I was wet through and 
through, and felt very cold, and I went into my berth and pullod the blanket around mo, and fell asloep. After that I had the fever very bad. I didn't know when we landed at Quebec, and after tbat I didn't know where we were for fire weeks, nor nothing."

I ascured him that this was only a natural and necencary consequence of his own conduct, and twok the opportunity to explain to him some of those simple laws by which be held both health and exietence, to all which be listened with an intelligent look, and thanked me cordially, adding -

" Then I wonder I didn't die! and it was a great mercy I didn't."

"I hope you will live to think so, and be thankful 20 Heaven. And so you were detained at Quebec ?" "Yes; my father had some money to receive of Lin peosion, but what with my illneas and the expowse of living, it soon went; and then be sold his silvor watch, and that brought us on to York-that's Toronto now. And then there was a sebeoner provided by governmemt to take us on board, and we led rations provided, and that brought us on to Port Stanley, far below Port Talbot; and then they put w achore, and wo had to find our way, and pay our way, to Delaware, where our. Jot of land was; that cost oight dollars; and then wo had nothiag leftnothing at all. There were nine hundred emigrants encamped about Delaware, no better off than ourcelves."

"What did you do then.? Had you not to build a house ?" 
"No; the government built each fumily a house, that is to say, a log-hut, eighteen feet long, with a hole for the chimney; no glass in the windows, and empty of conrse; not a bit of furniture, not even a table or a chair."

"And bow did you live ?"

"Why, the first jear, my father and us, we cleared a couple of acres, and sowed wheat enough for next year."

"But meantime you must have existed-and without food or money-?"

" $O$, why we worked meantime on the roads and got half a dollar a day and rations."

"It must have been rather a hard life ?"

"Hard! yes, I believe it was; why, many of them couldn't stand it, no ways. Some died; and then there were the poor children and the women -it was very bad for them. Some wouldn't sit down on their land at all; they loat all heart to see overy where trees, and nothing beside.

And then they didn't know nothing of furming how should they ? being soldiers by trade. There was one Jim Grey, of father's regiment-be didn't know how to handle his axe, but he could handle his gun well; so he went and shot deer, and sold them to the others ; but one day we missed him, and he never came back; and we thought the bears had got him, or may be he cleared off to Michigan -there's no knowing."

"And your father ?"

" $O$, he stuck to his land, and ho has now five acres cleared : and be's planted a bit of a garden, 
and ho hes two cows and a calf, and two pigs; and he's got his bouse comfortable - and stopped up the boles, and built himself a chimney."

"That's well; but why are you not with them ?"

“ $O$, he married again, and he's got two children, and I didn't like my stepmother, because she didn't use my sisters well, and so I came away."

"Where are your sisters now ?"

"Both out at service, and they get good wages; one gets four, and the other gets five dollars a month. Then I've a brother younger than myself, and he's gone to work with a shnemaker at London. But the man drinks hard-like a great many bere-and I am afoard my brothor will learn to drink, and that frots me; and he won't come away, though I could get him a good place any day-no want of places bere, and good wages too."

"What wages do you recoire ?"

"Seven dollare a month and my board. Next month I shall hero eight."

"I hope you put by some of your wages ?"

"Why, I bought a yoke of steors for my father last fall, as cost me thirty dollars, but they won't be fit for ploughing these two years."

(I should inform you perhaps, that a yoke of oxon fit for ploughing costs about eighty dollars.)

I pointed out to him the adrantages of his present situation, compared with what might have been his fate in the old country, and urged bim to aroid all tomptations to drink, which he promised.

"You can read, I euppose ?"

Ho hooitated, and looked down. "I cax read in 
the Testament a little. I never had no other book. But this winter," looking up brightly,-_" $I$ intend to give myself some schooling. A man who has reading and writing, and a pair of hands, and keeps sober, may make a fortune here-and so will I, with God's blessing !"

Here be gave his whip a very expreseive flourish. We were now near the summit of a bill, which he called Bear Hill; the people, he said, gave it that name because of the number of bears which used to be found here. Nothing could exceed the beauty and variety of the timber trees, intermingled with the most luxuriant underwood, and festooned with the wild grape and flowering ereepers. It was some time, he said, since a bear had been shot in these woods; but only last spring one of his comrades had found a bear's cub, which he had fod and taken-care of, and had sold within the last few weeks to a travelling menagerie of wild beasts for five dollars.

On reaching the summit of this hill, I found myself on the highest land $I$ had yet stood upon in Canada, with the exception of Queenston beights. I stopped the horses and looked around, and on every side, far and near, east, west, north, and eouth, it was all forest-a boundless sea of forest, within whose leafy recesses lay hidden as infinite variety of life and movement as within the depths of the ocean; and it reposed in the moontide so still and so vast! Here the bright sunshine rested on it in floods of golden light; there cloud-shadows sped over its bosom, just like the effects I remember to have seen on the Atlantic; and here and there rose wreaths of white 
smoke from the now clearings, which, collected into little silver clouds, and hung suopended in the quiet air.

I gased and meditated till, by a process like that of the Arabien sorcerer of old, the present fell like a film from my eyes : the future was before me, with its cowns and cities, felds of waving grain, green lawns and villas, and churches, and temples-turretcrowned: and meadows tracked by the frequent foot-path; and railroads, with trains of rich merchandiso stesming along :- for all this will be! Will be? It is alroady in the aight of Him who hath ordained it, and for whom there is no past nor future : though I cannot bebold it with my bodily vision, even nono it is.

But is that wow botter than this present now ? When these forests, with all their solemn depth of ahade and multitudinous life have fallen beneath the axe-when the wolf, and bear, and deer are driven from their native coverts, and all this infinitude of animal and vegetable being has mado way for restlese, erring, suffering humanity, will it then be better? Better-I know not; but surely it will bo vell, and right in His eyes who has ordained that thus the course of things shall run. Those who see nothing in civilized life but its complicated cares, mistakes, vanities, and miseries, may doubt this-or despair. For myself and you too, my friend, we are of those who believe and hope; "who behold in progressive civilization, progressive happiness, progressive approximation to nature and to nature's God; for are we not in His hands ?-and all that Hedoes is good. 
Contemplations such as these were in my rnind as we descended the Hill of Bears, and proceeded through a beautiful plain, sometimes richly wooded, sometimes opening into clearings and cultivated farms, on which were usually compact farm-houses, each flanked by a barn three times as large as the house, till we came on to a pluce called Five Stakes, where I found two or three tidy cottages, and procured some bread and milk. The road here was no longer so good, and wẹ travelled slowly and with difficulty for some miles. About five o'clock we reached St. Thomas, one of the prettiest places I had yet seen. Here $I$ found two or three inns, and at one of them, styled the "Mansion House Hotel," I ordered ted for myself and good entertainment for my young driver and his horses, and then walked out.

St. Thomas is situated on a high eminence, to which the ascent is rather abrupt. The view from it, over a fertile, well settled country, is very beautiful and cheering. The place bears the christisn name of Colonel Talbot, who styles it his capital, and, from a combination of adventages, it is rising fast into importance. The climate, from its high position, is delicious and healthful; and the winters in this part of the province are milder by several degrees than elsewhere. At the foot of the cliff, or eminence, runs a deep rapid stream, called the Kettle Creek, (I wish

- When I remonstrated against this name for so beautiful a stream, Colonel Talbot told me that his first settlers had found a kette on the bank, left by some Indians, and had given the -river, from this slight circumstance, a name which he bad not thought it worth while to alter. 
they had given it a prottier name,) which, after a course of eight miles, and turning a variety of sawmilla, griat-milla, \&e. flows into Lake Erie, at Port Stanley, one of the beat harbors on this wide of the lake. Hero stoamboats and schooners land passengers and merchandise, or loed with grain, flour, lumbor. The roads are good all round; and the Talbot rood, carriod directly through the town, is the finest in the province. This road runs nearly parallel with Lake Erie, from thirty miles below Port Stanley, westward as far as Delawere. The population of St. Thomas is at present rated at seven bundred, and it 'has doubled within two years. There are three churches, one of which is very neat; and three taverns. Two newspapers are published bere, one violently tory, the other as violently radical. I found ceveral houses building, and in those I entered a general air of cheerfuiness and well-being very pleasing to contemplate. There is here an excellent manufacture of cabinet ware and furniture; some articles of the black walnut, a tree abounding here, appeared to me more beautiful in color and grain than the finest mahogany ; and the elegant veining of the maplewoud cannot be surpassed. I wish they were suff. ciently the fashion in England to make the transport worth while. Here I have seen whole piles, nay, whole forests of such trees, burning together.

I was very much struck with this beautiful and cheerful little town, more, I think, than with any place I have yet seen.

By the time my horses were refreshed, it was near 
seven o'clock. The distance from Port Tulbot is about twelve miles, bat bearing the road was good, I resolved to venture. The sky looked turbulent and stormy, but luckily the storm was moring one way while 1 was moving another; and, except a little sprinkling from the tail of a clond, we escaped very well.

The road presented on either side a succession of farm-houses and well-cultirated farms. Near the houses there was generally a patch of ground plant. ed with Indian corn and pumpkins, and sometimes a few cabbages and potatoes. I do not recolloct to have seon oue garden, or the least attempt to cultivate flowers.

The goodness of the road is owing to the systematic regulations of Colonel Talbot. Throughout the whole "country" none can obtain land without first applying to him, and the price and conditions are uniform and absolute. The lands are divided into lots of two hundred acres, and to each settler fifty acres are given gratis, and one bundred and fifty at three dollars an acre. Each settler must clear and sow ten acres of land, build a house, ( $a \log$ hat of eighteen feet in length,) and construct one chain of road in front of bis bouse, within three years; failing in this, he forfeits his deed.

Colonel Talbot does not like gentlemen settlers, nor will be have any settlements within a certain distance of his own domain. He never assoctates with the people except on one grand occasion, the anniversary of the foundation of his settlement. This is celebrated at St. Thomas by a festive meeting of vor. Iv. 
the most reapectable settlers, and the colonel himcolf opens the ball with one of the ladies, generally sbowing his tasto by selecting the joungest and prottiect.

The ereaing now began to close in, night came on, with the stars and the fair young moon in ber train. I folt much fatigued, and my young driver appeared to be out in his reckoning - that is, with regard to distance-for luckily he could not miss the way, there being but one. I stopped a man who was trudging along with an axe on his shoulder, "How far to Colonel Talbot's?" "About three miles and a half." This was encouraging; but a quarter of an hour afterwards, on asking the same queation of another, be replied, "About seven miles." $A$ third informed me that it was about three miles beyond Major Burwell's. The next person I met advised me to put up at "Waters's," and not think of going any farther to-night; however, on arriving at Mr. Waters's hotel, I was not particularly charmed with the prospect of a night's rest within its precincts. It was a long-shaped wcoden house, comfortless in appearance; a number of men were drinking at the bar, and sounds of revelry issued from the open door. I requested my driver to proceed, whicb he did with all willingness.

Wo had travelled nearly the whole day through open well-cleared land, more densely peopled than any part of the province $I$ had seen since $I$ left the Niagara district. Suddenly we came upon a thick wood, through which the road ran due west, in a straight line. The shaduws fell deeper and deeper 
from the depth of foliage on either side, and I could not see a yard around, but exactly before me the last gleams of twilight lingered where the moon was setting. Once or twice I was startled by seeing a deer bound across the path, his large antlers being for one instant defined, pencilled, as it were, against the sky, then lost. The darkness fell deeper every moment, the silence more solemn. The whip-poorwill began his melancholy cry, and an owl sent forth a prolonged shriek, which, if I had not heard it before, would bave frightened me. After a while my driver stopped and listened, and I could plainly hear the tinkling of cow-bells. I thought this a good sign, till the boy reminded me that it was the custom of the settlers to turn their cattle loose in the summer to seek their own food, and that they ofien strayed miles from the clearing.

We were proceeding along our dark path very slowly, for fear of accidents, when I beard the approaching tread of a horse, and the welcome sound of a man whistling. The boy hailed him with some impatience in his voice, "I say!-mister! whereabouts is Colonel Talbot's ?"

“The Colonel's? why, straight afore you;-follow your nose, you buzzard!"

Here I interposed. "Be so good, friend, as to inform me how far we are yet from Colonel Talbot's house ?"

"Who have you got bere?" eried the man in surprise.

"A lady, comed over the sea to risit the Colonel."

"Then," said the man, approaching my carriage 
-my cart, I should say, - with much respect, "I gueas you'ro the lady that the Colonel has been looking out for this woek past. Why, I've been three times to St. Thomas's with the team after you !"

"I'm very sorry you've had that trouble !"

" $O$ no trouble at all $\rightarrow$ shall I ride back and tell him you're coming ?"

This I declined, for the poor man was evidently going bome to his supper.

To hear that the formidable Colonel was anxiously oxpecting me was very encouraging, and, from the man's description, I supposed that we were close to the house. Not so; the road, mocking my impatience, took so many bends, and sweeps, and windings, up bill and down hill, that it was an eternity before we arrived. The Colonel piques himself exceedingly on this graceful and picturesque approach to his residence, and not without reason; but on the present occasion I could have preferred a line more direct to the line of beauty. The darkness, which concealed its charms, left me sensible only to its length.

On ascending some high ground, a group of buildings wras dimly descried. And after oversetting part of a unake-fence before we found an entrance, we drove up to the door. Lights were gleaming in the windors, and the Colonel salliod forth with prompt gallantry to receive me.

My welcome was not only cordial, but courtly. The Colonel, taking me under his arm, and onder. log the boy and his horses to be wcll taken care of, Aanded mo into the hall or veatibule, where sacks of 
wheat and piles of sheep-skins lay heaped in primitive fashion; thence into a room, the walls of which were formed of naked logs. Here no fauteuil, spring-cushioned, extended its comfortable arms-no sofa here "insidiously stretched out its lazy length;" Colonel Talbot held all such luxuries in sovereign contempt. In front of a capacious chimney stood a long wooden table, flanked with two wooden chairs, cut from the forest in the midst of which they now stood. To one of these the Colonel handed me, with the air of a courtier, and took the other himself. Like all men who live out of the world, he retained a lively curiosity as to what was passing in it, and I -was pressed with a profusion of questions as well as hospitable attentions; but wearied, exhausted, aching in every nerve, the spirit with which $I$ had at first met him in his own style, was fast ebbing. I could neither speak nor eat, and was soon dismissed to repose.

With courteous solicitude, he ushered me himself to the door of a comfortable, well furnished bedroom, where a fire blazed cheorfully, where female hands had evidently presided to arrange my toilet, and where female aid awaited me;-so much had the good Colonel been calumniated ! 
Rt:

$$
-
$$

Digitized by Google 

Digitized by GoOgle 

Digitized by GOOgle 
JUN 131955

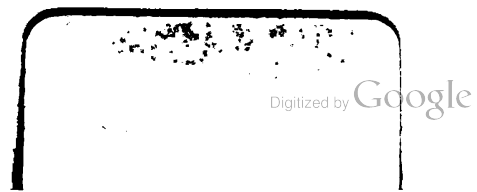

